\title{
Public Administration Reform and Building of the 'Vertical of Power' in Russia: Exploring Incommensurability
}

by

\section{Mikhail Zherebtsov}

A thesis submitted to the Faculty of Graduate and Postdoctoral Affairs in partial fulfillment of the requirements for the degree of

Doctor of Philosophy

in

Political Science

Carleton University

Ottawa, Ontario

(C) 2014

Mikhail Zherebtsov 


\begin{abstract}
The dissertation explores the reform of Russian public administration that began in 2003 . Although, it was considered by the ruling elite as one of the most important political projects that should establish a necessary fundament for further socio-economic modernization of the country, the reform has not yet resulted in significant improvement of governance in the country. The dissertation investigates the conceptual inconsistency of the model of reform, based on the New Public Management approach, and the nature of political process in Russia, established during the presidency of Vladimir Putin and named building the 'vertical of power'.
\end{abstract}




\section{Acknowledgements}

The author is particularly grateful to Professor Joan DeBardeleben for her supervision and extensive help throughout of the entire research project. Also the author greatly appreciates the help and advice of Professors Andrea Chandler and Piotr Dutkiewicz in the preparation of this dissertation. 


\section{Table of Contents}

Introduction: the public administration reform in the Russian Federation as the topic of academic

research.

Chapter I. Public Administration, Public Policy and Political Process in the Russian Federation: building the vertical of

power...

Chapter II. Public administration and civil service in post-Soviet Russia: the need for reform.

Chapter III. The Choice of Model

Chapter IV. Implementation of policies: public administration reform.

Chapter V. Implementation of policies: the reform in the sphere of civil service.

Chapter VI. New Public Management measures in the Russian reform project: successes and

failures.....

Conclusion.

Bibliography. 


\section{Chapter IV.}

p.307 Table 1. Analysis of significance of salary diversification among the three groups of federal government employees.

p.314 Table 2. Russia's position in the Global Competitiveness Index Report Survey (selective indexes)

\section{Chapter VI}

p.391

Table 1. Federal government's cross-departmental statistics of state procurement in 2012.

pp.401-402 Table 2. Nomenclature of goods and services procured by public administration divisions. 


\section{List of Illustrations}

\section{Chapter II}

p.138

Figure 1. Comparison of budget expenses on the Presidential Administration and the Federal Government of Russian Federation (as a percentage of expenditures on all federal executive institution).

p.162 Figure 2. Public sector to the total workforce ratio (in \%)

p.163 Figure 3. Percentage of the 'government' sector to the total workforce in Russia in 1990s

\section{Chapter III.}

p.194

\section{Chapter IV.}

p.298

p.302

p.305

p.311

p. 312

p.313

\section{Chapter V}

p.335

p.337

\section{Chapter VI}

p. 385

p.393

p.404

pp.418-419

Figure 1. Political-economic continuum of contemporary theoretical debates on public policy and administration.

Figure 1. Institutions of the federal government since the beginning of the reform (2004-2013)

Figure 2. Volatility of institutions of the federal government since the adoption of the three-layer system of public administration in Russia (p.276)

Figure 3. Federal public employees' remuneration by type of institution.

Figure 4. GRICS performance indicators.

Figure 5. GRICS government efficiency index 2000-2011: Russia in comparative perspective.

Figure 6. Business indicators of performance of Russia's public administration.

Figure 1. The quality dynamic of public officials employed by the federal institutions of executive power (thousands of employees).

Figure 2. Quantity of public officials at the federal, regional and municipal levels (thousands of employees).

Figure 1. State procurement as a percentage of GDP (in real money)

Figure 2. Corruption perception by business community in Russia (BEEPS Survey)

Figure 3. Distribution of settled contracts according to the type of used procurement procedure in 2012.

Figure 4. The outsourcing matrix 
Figure 5. Efficiency of outsourcing in the Ministry of Defense

p.429 Figure 6. United Nations E-governance Index Trend for the Russian Federation 


\section{List of Appendices}

p. 466 Appendix I. The Media Context of the Reform of Public Administration. pp. 467-468 Appendix II. Structure of the Government of Russian Federation 


\section{Introduction: the public administration reform in the Russian Federation as the topic of academic research}

The henceforth presented dissertation research considers the highly important, yet at the same time unjustly under-investigated problem of public administration reform in the Russian Federation. This has been one of the most important, yet long-awaited reforms that was undertaken in the post-Soviet period. It should not only help overcoming the administrative principles and legacies of the Soviet historical period, but also transform the system of governance in Russia in a way that would become the facilitator in the country's further development. Regardless of high expectations that were coupled with deliberate planning, the first decade of the reform has not resulted in substantial improvement of quality of public service in Russia. The given dissertation is one of few attempts to assess the objectives, the process, and first outcomes of the reform of public administration in Russia. Contemplations on the causes of reform's setbacks lead to a conclusion that the design of the reform contradicted to the major course of the political process in Russia that was established under the second president of Russia Vladimir Putin.

In the manifold of academic literature, related to the post-Soviet development of Russia, the topic of public administration as a particular aspect of governance studies is not among the favourites. It has been largely outnumbered by the studies of evolution of the political regime after the collapse of the Soviet Union, as well as problems that the country faces on its way to the democratic society. In the first decade of the 21 st century academic debates refocused on the "failure" of the democratic project and re-emergence of authoritarianism in Russia, ultimately questioning the validity of the transitional 
paradigm. Studies of functioning of public administration were largely outnumbered by the studies of changes of political regime, transformation of perceptions of democracy from the western-liberal to a sovereign-type concept, or some case-studies, though quite important, like the 'Yukos affair'.

Yet, importance of public administration reform should not be underestimated, as its functioning, evolution, performance and failures appear to be at the epicenter of political process, as well as academic debates. In everyday political life, officialdom often becomes, sometimes quite rightfully, the object of criticism not only by regular citizens, but also politicians. Many political theories, in order to accommodate the posited argument, willingly or not, reflect and refer to current trends in public governance. Studies of public policy and public administration became one of the fundamentals of the contemporary political science, finding theoretical insights and adopting technologies from many other academic fields, such as economics, sociology, psychology, organizational studies. Multiple international researches contributed to a comparative approach in public administration studies. This aspect became crucial especially in regards to the rise in prominence of the New Public Management doctrine that has become the paradigmal framework for thinking about public governance in almost all countries in the last 30 (or so) years. Yet, surprisingly, this trend has not had a great impact on the studies of political process in the post-Soviet states, and mainly Russia. The dissertation provides an overview of the political process in Russia prior and during the reform in order to assess how it affected the development of the country. 


\section{Situating the problem}

\section{The context}

In order to analyze public administration reform in Russia, it is important to put it in the context of political, economic and social transformations that have occurred in the country. A few arguments shall be raised in support of the importance of the topic. First of all, the reform of public administration should be understood as the process of rethinking, as well as qualitative and quantitative rearrangement of public institutions, public functions and public cadres. If this definition is accepted, then this has been the first practical attempt to reform the Russian government after the collapse of the Soviet Union. A few attempts to modernize the state apparatus were undertaken in the 1990s, however they did not even proceed to the stage of implementation. In all cases, the lack of success of these attempts was explained by poor economic performance of the country, as well as by weakness of its democratic political institutions. It was stated that under such circumstances conducting the reform of the state apparatus could have even more detrimental consequences than attempts to preserve the status quo. Thus, political instability of the early post-Soviet years was followed by the economic hardships of Yeltsin's first presidential tenure. Later, electoral cycles of 1995/1996 and 1999/2000 postponed reformatory initiatives in the sphere of governance, as far as the political elites were preoccupied with different objectives and reforming the state apparatus was considered too risky.

Secondly, the current reform of public administration was positioned by its implementers as the basic project that binds together other fundamental reforms (e.g., federative relations, political, electoral, and local self-governments). In addition, success 
of this reform, or, in other words, establishment of a modern and efficient public administration, was pronounced one of the keys to success in other, especially social and economic reforms. The system of relations between public administration and business community should be modernized in such a way that the former would no longer be an impediment to the economic development of the country.

Thirdly, it can be argued that that at this stage (i.e., first presidential tenure of Vladimir Putin) the reform was practically inevitable, and it could not be procrastinated any longer. During the 1990s, for political and economic reasons, the state apparatus was adapting to the new political and economic realities incrementally, preserving rudimental governance practices, inherited from the Soviet system. Throughout the first post-Soviet decade the Russian officialdom had been developing as a cumbersome, unresponsive mechanism of governance, plagued by imperfect institutional structure and inefficient public service. Incremental transformation of the state apparatus led to departmental incoherence and blurred functional responsibilities. To put it simply, it was often not obvious what governmental department must take responsibility for a particular state function. This created a serious accountability issue. In addition, the government was a rather weak and segmented institution, vulnerable to the external influence in the forms of corporate lobbyism and corruption. This reform put removal of these practices and overcoming the Soviet administrative legacies at the core of its agenda.

The reform was launched in 2003. At that stage it was almost inevitable, as current administrative processes had become impediments to the broader reform agenda, proposed in late-1999 by Vladimir Putin, then acting president, at the very beginning of his first term. Since his inauguration President Putin had been returning, in some way or 
another, to the necessity of the reform of the administrative system in almost all his annual presidential addresses to the parliament, until 2003, when he stated that "the success of the reform is a necessary condition for further economic and social modernization of Russia." ${ }^{\prime 1} \mathrm{He}$ also mentioned in his speech that four major top-priority political programs, called 'the National Projects' (Natsional'nye proekty) - 'public health', 'education', 'housing', 'agriculture' - would not be successfully implemented without building effective institutions of public service as the major instrument of public policy implementation. The growing discontent of civil society and of the business community with the quality of services provided by the state, as well as the existence of the so-called 'administrative barriers' (administrativnye bar'ery), all indicated the urgent need for rapid and fundamental changes in the system and principles of governance. Growth of corruption rates, tracked by notable international organizations, served as another objective indicator of the degradation of the bureaucracy in Russia. Sociodemographic, gender, labor, and educational deficiencies of the state apparatus posed tangible threats of interruptions of service delivery in addition to the apparent deterioration of the quality of fulfilment of state functions and provision of public services. In addition, scholars stressed ideological problems, such as the necessity for Russia to overcome its Soviet legacy and continue developing democratic institutions and principles of governance in the sphere of public administration.

${ }^{1}$ Vladimir Putin (2003), Annual address of the President of the Russian Federation to the Federal Council of the Russian Federation. (Online), [URL: http://kremlin.ru/appears/2003/05/16/1259 type63372type63374type82634 44623.shtml (Accessed: October 10, 2007). 
Obviously, the system of Russian bureaucracy demanded a reform, as far as it was inadequate to the new political realities that started to take shape in the first months of Putin's presidency. At the core of changes was the project of a fundamental restructuring of the system of political relationships in Russia that proposed a new outlook on public policy. The project began with reinstatement of the role of the federal centre and transformation of the nature of regional politics in the country. It later was extended to other aspects of the political process in Russia, such as partisan politics and elections. Conceptually it was institutionalized in the doctrine of the 'vertical of power'. Reshaping of the political sphere also demanded rethinking the approaches to understanding of the role of public administration. The latter should be given a particular place within the vertically integrated political sphere.

\section{The design and implementation of the reform}

As discussed above, a spectrum of political, economic, social, institutional and managerial/administrative factors allow placing the reform of public administration ${ }^{3}$ at the core of political transformations launched in Russia in the early $21^{\text {st }}$ century. High expectations for the reform demanded careful and deliberate planning, including the selection of its ideology and conceptual parameters. Its success was crucial not only for adequate functioning of the entire political system, but also for many social and economic reforms that were conceived by the ruling elites. It was decided that the reform of public administration in Russia would be based on a well-developed theoretical approach. At its core would be the doctrine of New Public Management (NPM) that has become a

${ }^{2}$ Hereafter, the phrases such as "the vertical of power" and "the power vertical" will be used throughout the dissertation as identical ones.

${ }^{3}$ The terms 'the reform of public administration', 'the administrative reform, 'the reform of governance' are used in the dissertation as identical. 
hallmark for successful transformation of public institutions in many countries worldwide. Undoubtedly, NPM was the most popular theoretical approach to governance and it has dominated the reform agendas and academic debates for several decades. Although it was not an unquestionably successful concept, many countries that adopted it showed significant improvements in the quality and effectiveness of their public administrations.

Having been blamed for uncritical adoption of many Western-type reforms in the past, this time the political elites decided to launch a public discussion about the future reform. The established State Committee for the Reform, in addition to public officials, included scholars and public figures, who took active part in discussions of the doctrinal and practical aspects of inculcation of managerial principles into the Russian tradition of governance. Therefore, discussion of this particular reform project can no longer be limited to the criticism of thoughtless transfer of the Western political and administrative standards to the unprepared Russian soil. Instead, this reform can be considered to be well grounded in both the state-of-the-art theory of public administration and understanding of peculiarities of the contemporary political process in Russia.

However, shortly after its launch the reform began receiving critical appraisals regarding the implementation process, as well as in respect to some of its fundamental premises. Notable politicians, businessmen and experts started to express concerns about how the reform was being implemented and gave estimates of its results. ${ }^{4}$ Even leaders of

${ }^{4}$ In December 2004, Mayor of Moscow Yurii Luzhkov mentioned that he was unsure about the goals of the reform of public administration in Russia (See: "Yury Luzhkov podverg rezkoi kritike administrativnuiu reformu v Rossii i biudzhetnuiu politiku federal'nogo pravitel'stva." (2004, December 8) Echo Moskvy. (Online) [URL http://www.echo.msk.ru/news/220421/comments.html] (Accessed May 22, 2010). Evgenii Primakov, president of the Russian Chamber of Industry and Commerce, argued the reform appeared to be ineffective and did not introduce any substantial changes to the 
the ruling political elite themselves pointed to some difficulties in the process of reform implementation. Already in the early stages of the reform President Putin admitted difficulties that the reform had faced. ${ }^{5}$ Talking to the Russian business elites in November 2004 he stated that the reform was quite unsuccessful in separating the political and administrative functions of the state apparatus. He said that "even initiators and authors of the reform... violated the very principles that were declared by themselves." ${ }^{.6}$ In 2006 the head of the State Duma Boris Gryzlov stated that the reform failed to decrease the quantity of public officials. Dmitry Medvedev, at the time of his presidency, addressed several issues of the administrative reform in his public speeches. He emphasized the fact that the reform was not successful in increasing transparency and accountability of the state apparatus, as well as its effectiveness. ${ }^{7} \mathrm{He}$ also admitted that penetration of the state

system of governance in Russia ("Neobkhodimo reanimirovat' administrativnuiu reformu, uveren Evgenii Primakov" (2008, March 28) FK-Novosti. (Online). [URL http://www.fcinfo.ru/themes/basic/materials-

document.asp? folder $=1446 \&$ matID $=173490$ ] (Accessed May 22, 2010). Governor of Vologda oblast Viacheslav Pozgalev argued in 2007 that the reform "caused enormous damage to the state" by actually increasing the amount of agencies (See: "Gubernator Vologodskoi oblasti Viacheslav Pozgalev: Odnoznachno mogu zaiavit administrativnaia reforma provalilas" (2007, September 24). Derrik.ru (Online) [URL http://www.derrick.ru/?f=n\&id=12075]. (Accessed May 22, 2010).

${ }^{5}$ See: "Putin priznaiot oshibki pri provedenii administrativnoi reformy." (2005, July 2). RIA Novosti. (Online) [URL http://www.rian.ru/politics/20050702/40833758.html]. (Accessed May 22, 2010).

${ }^{6}$ Vera Sitnina (2004 November 17) "Vladimir Putin kak stimul dlia biznesa." Vremia Novostei, No.210. (Online) [URL: http://www.vremya.ru/2004/210/4/112444.html], (Accessed: October 12, 2007).

${ }^{7}$ Dmitry Medvedev criticized ineffectiveness of measurements for implementation of the federal program "Electronic Russia" that is aimed to increase effectiveness of public policy as well as enhance transparency of state organizations. (See: "Medvedev: "elektronnoe pravitel'stvo" v Rossii do sikh por "khimera"" (2009, February 2) RIA Novosti (Online) [URL: http://www.rian.ru/society/20090212/161893581.html]. (Accessed May 22, 2010). 
into the economy had not yet decreased. ${ }^{8}$ The head of the Chamber of Commerce and Industry Evgeniy Primakov argued that public sector reform in Russia "had died before being born." $\mathrm{He}$ saw the problem in reluctance of bureaucrats to support further decentralization and to transfer excessive state functions from public to private agencies. Public officials, directly involved in the process of reform implementation, had to acknowledge difficulties in the reform process, although they were not as critical as some politicians or independent observers. For example, in 2007 Andrei Sharonov, then, a high-profile public official from the Ministry of Economic Development and Trade, argued that the reform should not be considered a failure. "To put it simply, its time constraints had to be extended, because the object of the reform appeared to be very complex, cunning and dodgy."10

Critical opinions of politicians and scholars about the progress and efficiency of the reform are reinforced by empirical evidence. The most obvious indicator would be delays in the implementation of planned measures for the reform. For example, the second and most crucial stage of the reform was extended for two more years, from the initially planned 2008 until 2010. Obviously, the reform of public administration in Russia faces evident challenges. Some of these challenges had already been foreseen by

8 "D.Medvedev: "Biznes ne dolzhen oplachivat' 'kazhdyi chikh' gosudarstva"” (2009, August 05). RosBusinessConsultin, (Online) [URL: http://top.rbc.ru/economics/05/08/2009/319983.shtml]. (Accessed May 22, 2010).

9 Aleksandr Bondar'. (2006, December 8) “Administrativnaia reforma v Rossii umerla, ne rodivshis', schitaet glava TPP RF". FK-Novosti. (Online) [URL: http://www.tpprf.ru/common/upload/files/2006121211533920.doc] (Accessed May 22, 2010).

10 Maksim Rubchenko (2007) "Biurokratiia adaptivnaia i mimikriruiuschaia." Expert No.19 (560). 
the experts even before the start of the reform; others were revealed during the early stages of its implementation.

Special attention should also be paid to public perceptions of the reform. The public discourse on the subject matter is rather vague and does not create a substantial incentive for change either for the bureaucrats, or for the politicians controlling them. The number of publications in the print media on the course of the reform has been gradually declining. Media interest in the administrative reform reached its apogee in 2004, when the most obvious changes to the structure of the federal government were made. Already in the next year the number of publications declined by two times and continued to decrease gradually in the following years. (See Appendix I for more details).

On the one hand, the situation can be explained by the nature of the reform itself. Changes in the state apparatus, especially internal ones (e.g., pertaining to the modus operandi of public officials), may occur unnoticed by the general population. Unlike many social reforms, they do not affect the everyday life of people. ${ }^{11}$ Therefore, the interest of ordinary people towards the reform remained low, as underdevelopment of the institutions of civil society prevented creation of articulated pressure groups that would enhance public control of and awareness about the reform process.

Objectively, the reform of public administration produced mixed results and cannot be regarded as an unquestionable success. Lack of success of the reform project, based on a well-developed model of governance, raises questions about not only the

${ }^{11}$ In this regard the 2005 reform, aimed at monetization of social benefits, that spurred a series of public unrests throughout the country, serves a very good example. See: Irina Petrakova, Vadim Biserov. (2005, February 28). "L'gotniki sozhgli Putina." Gazeta.ru, (Online), [URL: http://www.gazeta.ru/2005/02/28/oa 149600.shtml] (Accessed October 12, 2008). 
reform design itself, but also the political environment in which the reform is being implemented. The description of the reform, provided in the preceding paragraphs, denotes two particular spheres, or problematic points, which, upon deeper investigation, may shed light on the actual reasons why the reform did not result in a significant improvement of governance in Russia. First of all, the design of the reform itself might have been flawed, as the authentic managerial approach was substantially modified in the Russian case. In addition to this, the selection of particular NPM measures could have its effect on the course of reform. Such advanced measures could be detrimental, given the fact that Russian public administration suffered from the Soviet legacies that substantially modified the starting conditions of the reform. Secondly, the process of the reform might introduce distortions to the initial strategy that are more substantial than the already mentioned delays in implementation.

\section{Existing body of knowledge}

The given state of knowledge about the problem does not provide ready explanations of causes of difficulties. Nor does it propose scenarios for overcoming emerging difficulties. No obvious solutions have been presented in the existing literature. Even comments of politicians, businessmen and, more importantly, experts usually pose the problems, but do not explain their causes or provide effective solutions. The factors that caused difficulties in reform implementation remain under-researched.

The existing body of knowledge on the subject matter can be split into two distinctive categories. The first category includes the scope of literature on post-Soviet development that pays great attention to the Russian case, but at the same time largely disregards the reform of public administration. The second category includes a very large 
cluster of scholarly work on public administration. In addition, with respect to both categories a special perspective should be added that draws distinction between the Western (English speaking) and national (Russian language) academic tradition. It can be stated that the research agenda of the post-Soviet cluster is similar in both traditions.

At the same time this feature becomes important when the cluster of public policy and administration studies is taken into consideration. According to this logic the entire cluster can be split into three major sub-categories: general studies of the most advanced projects of public administrations reform (particularly in the developed countries like the United Kingdom, The United States, or Canada); cross-national comparative studies of public administration reforms; and studies of Russian public administration reform. Obviously, the latter category is dominated by the Russian-language scholarly work.

As it has already been stated, as relates to the first category (literature on postSoviet development), almost the entire nomenclature of scholarly work discusses issues of public administration only tangentially. With few exceptions, however insightful and coherent, most studies analyzing Russian public administration were made within the Russian academic tradition and published in domestic, Russian-speaking academic journals and monographs. Such situation reflects the paradox: one of the most fundamental aspects of the post-Soviet political development of Russia remains underresearched and underrepresented. Their major concern is about resurrection of the state under Vladimir Putin and his 'crusade' against democracy. ${ }^{12}$

${ }^{12}$ See for example: C. Roberts, T. Sherlock (1999) "Bringing the Russian state back in. Explanations of the Derailed Transition to Market Democracy." Comparative Politics, Vol. 31, No. 4.; Richard Sakwa (2008) Putin: Russia's Choice, 2nd ed., London: Routledge; or Brian D.Taylor (2011) State Building in Putin's Russia: Policing and Coercion After Communism. NY: Cambridge University Press. 
Having established the major trends in the field of post-Soviet studies we now turn to the cluster of public administration scholarly works. All advanced and pioneering studies in the field of governance have been focused on the reform projects located mainly in the developed countries. Moreover the sample of research agenda is significantly skewed towards the Anglo-Saxon countries, where NPM reforms achieved results on the larger scale than the reforms in the Continental European countries. The models exploit political theories of governance and research methods that recognize other politically important institutions (parties, civil societies etc.) and concepts (democracy, representation etc.) as well-established and, generally, normally functioning. The case of Russia, obviously, deviates from the mainstream by many standards. Yet Russian reformers followed up the major international trend and adopted the ideas and technologies of governance that were developed in such advanced polities. This fact makes rather important the academic approaches that, by virtue of expertise, helped perfecting implementation of new principles of public policy.

The theory of New Public Management has been critical for designing and conducting reforms of public administration and produced an avalanche of publications on the subject matter, both supporting and opposing the movement. New Public Management is often associated with political-economic movements of late 1970s-early 1980s that occurred throughout the OECD bloc of countries and mainstream political ideology in the United States and the United Kingdom. Public and economic reforms in these countries were driven by shifts in paradigms of economic thinking from Keynesianism to monetarism. These revolutionary transformations were given names, such as 'Reaganomics' and 'Thatcherism' after the countries' leaders during the period of 
transformation. Although the monetarist political-economic movement and the new public management approach are not conceptually identical projects, they share a lot of ideas.

A seminal work - Reinventing Government: How the Entrepreneurial Spirit is Transforming the Public Sector - was published by David Osborne and Ted Gaebler in 1992. This monograph can be marked as the starting point of domination of the NPM doctrine in public policy studies. Another very important contribution to the field was made by the American scholar B. Guy Peters, who published his "The Future of Governing" in $1996 .{ }^{13}$ Each piece contributed substantially to specifying and honing the concept of managerialism in regards to public policy. A variety of opinions and the existence of academic (and public) debates on the essentials of managerialism in the public sphere made New Public Management a lively and reflective international academic field. For example, American authors assess NPM as being not a mere academic construction. Rather it is an example of a genuinely grass-roots managerial revolution since it started as a response to malfunctions of traditional bureaucratic government. NPM was initiated from the bottom up, initially affecting municipal authorities and further disseminating on the national level. ${ }^{14}$ This idea is repudiated by European colleagues, who argue that "public management reform - certainly in central governments - is a process that tends to begin in the upper rather than the lower reaches

13 Peters, B. Guy (1996) The Future of Governing: four emerging models. Kansas: University of Kansas Press.

14 David Osborne and Ted Gaebler (1992) Reinventing Government: How the Entrepreneurial Spirit is Transforming the Public Sector., NY: Penguin Books, p.16. 
of governance..." and in its core "lies the process of elite decision-making."15 But regardless of situational disputes, authors were unanimous regarding the fundamentals of the field. These fundamentals may be concisely expressed as follows:

Most entrepreneurial governments promote competition between service providers. They empower citizens by pushing control out of the bureaucracy, into the community. They measure the performance of their agencies, focusing not on inputs but on outcomes. They are driven by their goals - their missions-not their rules and regulations. They redefine their clients as customers and offer them choices-between schools, between training programs, between housing options. They prevent problems before they emerge, rather than simply offering services afterward. They put their energies into earning money, not simply spending it. They decentralize authority, embracing participatory management. They prefer market mechanisms to bureaucratic mechanisms. And they focus not simply on providing public services, but on catalyzing all sectors-public, private, and voluntary-into action to solve their community's problems. ${ }^{16}$

The academic maturity of the concept resulted in appearance of comprehensive monographs that tend to provide a holistic contemporary outlook on the New Public Management approach. Such texts like The Oxford Handbook of Public Management (first published in 2005) ${ }^{17}$ and The Ashgate Research Companion to New Public Management (published in 2011) ${ }^{18}$ discuss a variety of issues related to implementation and functioning of NPM public administrations. Both texts not only discuss fundamentals and key aspects of the managerial revolution, but also take into account sectoral peculiarities and regional differences. Yet neither text outlined specificities of

15 Christopher Pollitt and Geert Bouckaert (2004) Public Management Reform: A Comparative Analysis (2nd ed.), Oxford, UK: Oxford University Press, p.26.

${ }^{16}$ David Osborne and Ted Gaebler (1992) Op.cit., pp.19-20.

17 Ewan Ferlie; Laurence E. Lynn; Christopher Pollitt (eds.) (2005). The Oxford handbook of public management. Oxford: Oxford University Press.

${ }^{18}$ Tom Christensen and Per Lægreid (eds.) (2011) The Ashgate Research Companion to New Public Management. Burlington, VT: Ashgate. 
governance reforms in the former Soviet Union countries, leaving the post-communist transition largely intact.

There is a growing nomenclature of NPM-related studies of public administration reforms in the developing countries, however. The countries of the Asian-Pacific region are quite active in this regard. This body of knowledge creates a fruitful comparative perspective and further justifies the paradigmal status of the New Public Management doctrine. As in case of the transition paradigm that posited that the only right vector of political modernization was towards the western-type democracy, ${ }^{19}$ problems of applicability of NPM for the modernization of public administration dominate the debates.

Once New Public Management became the major trend in thinking about government and public policy in the 1990s it was adopted as the mainstream approach by major international organizations, such as World Bank. The latter institution facilitated the reform project in Russia, especially during the preparatory stages in 2000-2003. Upon request from the Russian government Nick Manning and Neil Parison, experts of the World Bank, prepared a cross-country, comparative report on the reform of public administration implemented on the basis of the New Public Management paradigm. ${ }^{20}$ The report included countries that are considered "successful" in implementation of managerial reforms (e.g., New Zealand, Australia, the UK and the United States). These "success stories" were contrasted with experiences of countries that are close to Russia by geographic, socio-economic, demographic or even geopolitical factors (e.g. Rep. of

${ }^{19}$ See for example: Francis Fukuyama (1992). The End of History and the Last Man. NY: Avon Books

${ }^{20}$ Nick Manning, and Neil Parison. (2004) International Public Administration Reform: Implications for the Russian Federation., The World Bank, Washington. 
Korea, Poland, China, Germany etc.). The comparative approach allowed establishing major patters of the reform process that Russia could face with. The authors concluded that Russia would more likely fit the so-called low-traction cluster of reformers. This places the country alongside Germany, Poland, and Brazil.

The traction principle is determined by the variety of reform mechanisms, available for the reformers to approach the assigned goals. Therefore, low traction of the reform in some countries is explained by the lack of flexibility in choosing methods of reforming the public service. Moreover, reformers must take into account the parameters of the bureaucratic system they tend to modify as far as its malleability is considered low, and the discipline and internal coherence are not its values. The high vs. low traction approach provided authors with a powerful analytical tool. The approach allowed them not only to outline common pitfalls that countries with different type of traction to the reform face, but also to suggest potential solutions to these problems. For example, reformers in the countries with "limited traction had to be distinctly opportunistic, taking advantage of idiosyncratic developments as they emerged. ${ }^{21}$ Authors argue that as any other low traction country, Russia needs to emphasize "reforms that provide an underpinning of discipline and formality." ${ }^{, 22}$ Moreover, as a 'developing' country (unlike Germany) Russia does not have the opportunity to carry out simultaneously many crosscutting reforms; and, therefore, its major strategy should be to "spot promising developments as they emerge. ${ }^{23}$

\footnotetext{
${ }^{21}$ Ibid., p.47

${ }^{22}$ Ibid., p.47

${ }^{23}$ Ibid., p.47
} 
The Russian case of public administration reform, particularly, is not wellpresented in the English-language academic literature. Therefore, this literature does not contribute substantially to a better assessment of the paradigmal status of the New Public Manage doctrine. If managerialism is discussed on the conceptual level, the doctrinal cases of the United Kingdom, the United States, New Zealand and Australia are used. Comparative public policy literature adds more towards understanding of the difficulties of implementation of NPM. Such cases usually take into account traditional Continental European polities such as Germany, France, and Italy, and discuss peculiarities of implementing managerial principles of governance. Discussions of governance reforms in the Northern European countries, reinforced by the success-stories from the developing world, reveal the genuinely omnipresent and doctrinal status of the New Public Management paradigm.

Publications on the subject matter in the Russian academic periodicals and monographs are relatively numerous; however, given the scope of the reform, they may be considered insufficient. The development of the topic raises questions regarding not only the quantity, but also the content of the publications. The majority of works were published in the form of articles in scientific journals or short analytical essays in the official circulars. Most publications come from one recurring thematic Russian-language journal Voprosy gosudarstvennogo i munitsipal'nogo upravleniia ( Problems of state and municipal governance). Interestingly enough, one of the most prominent academic journals on Russian politics - Polis - has not yet paid substantial attention to the reform. Issues of bureaucracy and the reform of public service were presented in some other 
periodicals. However, the topic of public administration reform was rather underresearched.

Several comprehensive collective monographs dedicated to the subject were issued. One was co-edited by then deputy prime-minister Sergey Naryshkin. ${ }^{24}$ The other was compiled by the senior representative of the Ministry of Economic Development and Trade, Andrey Sharov. ${ }^{25}$ Both books represented an official outlook on the reform process. However, they were dated back to the early stages of the reform. This serves as a good explanation why the normative and descriptive approaches dominated throughout the articles, published in both monographs. They were more focussed on the issue of what ought to be done in order to succeed in the reform process. Most contributors to both monographs had a juridical background. This fact also made the approach in both books rather specific as authors tended to discuss political or organizational aspects of the reform from the normative-legal point of view. Both monographs have many aspects in common, including approaches to philosophy, methodology and appraisals of the reform. The driving normative approach, aimed at discussing the ways the reform should be conducted, resulted in an almost total avoidance of the critical analysis of the initial steps of the reform. Authors emphasised positive factors of improvement of governance in Russia that will come to life as a result of implementation of the reform. They tend to present the current reform as a gradual and continuous development of the state. As was

${ }^{24}$ Sergei Naryshkin, Talia Khabrieva (eds.) (2006). Administrativnaia Reforma v Rossii. Moscow: Infra-M.

${ }^{25}$ Andrei Sharov (ed.) (2004). Reforma gosudarstvennogo upravleniia v Rossii: vzgliad iznutri. Moscow: Higher School of Economics 
mentioned elsewhere, "administrative reforming may be considered as a constant function of the state.,26

Indeed most of the Russian papers tend to connect the current reform to the attempts that occurred earlier, in the 1990s. Aleksander Obolonskiy considers the current reform as the fifth consecutive round of attempts to modernize public administration in Russia that have been made since the dismantling of the Soviet Union. ${ }^{27}$ Another expert also outlined five different reforms, although time periods were marked differently. ${ }^{28}$ Aleksey Barabashev argues that there were three rounds of reform prior to the current one, whose preparatory stage was launched simultaneously with the beginning of the first presidential term of Vladimir Putin. ${ }^{29}$ Iulia Shevchenko's descriptive monograph The Central Government of Russia from Gorbachev to Putin, is further evidence of the domination of the continuity approach among Russian scholars. In this book changes in the structure and composition of the Russian government were traced back as far as 1985 and the author comes to a conclusion that "the government undergoes a continuous process of redesigning, which involves gradual elimination of those Soviet-era institutional forms that do not correspond to the new political realities."30

26 A. Logunov (2006). Administrativnaia reforma v Rossii: osnovnye etapy realizatsii. Analytical Bulletin of the Federation Council \#22 (310). , p.10

${ }^{27}$ Aleksandr Obolonskii, (ed.) (2009). Gosudarstvennaia sluzhba (kompleksnyi podkhod). Moscow: 'Delo'., Chapter 5.

${ }^{28}$ A. Logunov (2006) Administrativnaia reforma v Rossiiskoi Federatsii: osnovnye etapy realizatsii. Analytical Bulletin of the Federation Council. Ser.: Problems of State Building. No.22 (310)

29 Aleksey Barabashev (2013). "Evoliutsiia gosudarstvennoi sluzhby Rossii: itogi desiatiletiia (2000-2010)." Moscow: Higher School of Economics.

30 Shevchenko, Iulia (2004). The Central Government of Russia from Gorbachev to Putin. Burlington: Ashgate, p.180. 
One distinctive feature of the Russian academic tradition should be mentioned specifically. Since the early debates it has become common practice to consider the reforms of public administration and public service as separate and distinct. It may be argued here that academic studies simply followed the practical trend of conducting reforms in Russia. Indeed, in the earlier stages both reforms - of public administration and of public service - were designed as separate processes. Each reform had its own separate and quite original conception. Different administrative bodies were made responsible for the procedural conduct of each reform. Only recently have both reforms been reunited on the conceptual level. The "Conception of Reduction of Administrative Barriers", issued in June 2011 by Russian government, posited the necessity to amalgamate public service and public administration reforms together, along with the budgetary and 'the electronic government' reforms. ${ }^{31}$ It must be stated, however, that even in the first programmatic documents the reformers explained that "forming of the system of the public (state) service is being accomplished... in interaction with the administrative reform..." ${ }^{32}$ Yet, the studies of governance in Russia have remained analytically separated into two clusters.

Concluding the discussion on the existing literature devoted to the problems of the reform, it can be stated that eclecticism of the conceptions of administrative reform, developed in Russia demanded that researchers take a broader perspective on the intellectual background of the reform project. In the Russian case the transition was made

${ }^{31}$ Resolution of the Government of Russian Federation No.1021-r from June 10, 2011. Kontseptsiia snizheniia administrativnykh bar'erov i povysheniia dostupnosti gosudarstvennykh i munitsipalnykh uslug na 2011-2013 gody.

32 Order of the President of the Russian Federation No.Pr-1496, from August 15, 2001 "Kontseptsiia reformirovaniia sistemy gosudarstvennoi sluzhby Rossiiskoi Federatsii." 
not from the classical-style bureaucracy of the welfare state to a more contemporary and responsive model of governance; it was the transition from the ideologically dominated model of state administration that prevailed in the communist system. Therefore, the modernization project has been more than just about the officialdom - it has involved transformation of various political institutions and even the political culture and political psychology of the masses. It may be argued that the actual theoretical discussion that accompanied the reform in Russia was not purely technological, or pragmatic (i.e., addressing to which extent Russia is suitable for the NPM design of the reform). Rather it was ontological, addressing issues such as whether the Russian political process corresponds with the contemporary ideology of governance, or whether the country should initially undergo a series of supplementary stages and develop its political institutions before starting the managerially driven reform of its state apparatus.

Experts warned of the difficulties that the reform would face on the way to the modern public administration. Above all, they pointed to the ultimate and universal paradox of the reform - it must be implemented by the state apparatus itself. Thus, the traditional methodological separation of the subject and the object of reform actions is not applicable in this case. Public officials are destined to perfect themselves; and this ultimately creates conflicts of interests that cannot be fully avoided, only bypassed or managed. Most countries tried to solve these methodological issues by enhancing the role of public control through a variety of accountability mechanisms. ${ }^{33}$

${ }^{33}$ W. Robert Lovan, Michael Murray and Ron Shaffer, (2004). Participatory Governance in a Changing World in W. Robert Lovan et. al. (eds.) Participatory Governance: Planning, Conflict Mediation and Public Decision-Making in Civil Society. Burlington : Ashgate., pp. 1-20. 


\section{Importance of the topic}

The discussion provided above - regarding the reform design and process, the political conditions in which the reform has been undertaken, as well as the level of current theoretical debates on the subject matter - explain the importance of further investigation of the reform of public administration in Russia. Analysis of the factors that influenced the progression of the reform and its efficiency is important, as it would help to reveal factors that determined the reform's misfortunes. Moreover, the research can contribute substantially to understanding of applicability of contemporary technologies of governance to public administrations in transition.

\section{Theory, Methodology \& Research Design}

\section{The Concept \& Hypothesis}

As the discussion shows, public administration reform in the Russian Federation may definitely be considered by scholars, as well as politicians as a necessary part of a complex political transformation process initiated by President Putin during his first and second tenures. This process was based on three conceptual principles: 1) solidification of the executive branch on both the federal and regional levels (building 'the vertical of power'); 2) development of civil society and political culture in accordance with the principles of 'managed or sovereign democracy" ${ }^{34}$; and 3) the doctrine of 'the rule of law'. The model of the vertical of power puts significant emphasis on the bureaucratic apparatus as the major conductor of policies and as an important binding factor in the political hierarchy. These principles, while being implemented, resurrected the etatist

${ }^{34}$ Perry Anderson (2007) "Russia's Managed Democracy" London Review of Books. Vol. 29, No. 2., pp. 3-12. As far as both terms "managed" and "sovereign" democracy have been applied to the same political system, they are therefore considered in this dissertation as synonyms. 
political-ideological model that had been the driving force of the political process in Russia for many centuries. Under this ideology the state is perceived as the dominant actor and, in many cases, the driving force of changes in political, economic, and social life. This logic is applied to the public administration reform as well.

At the same time, the ideology of the proposed reform of public administration was initially dominated by the so called managerialist approach, which lies at the core of the doctrine of New Public Management. The approach emphasizes adoption of contemporary management and administrative practices from the private sector. It is partially biased by the "shrinking government" movement of the $1980 \mathrm{~s}^{35}$ in the way that it emphasized the need to transfer public functions to the private sector, where possible, in order to improve the quality of services and to reduce costs. The other aspect of the managerial approach was instituted in the "reinventing government" movement. The latter was conceptualized in the form of peculiar governmental programs - The Next Steps Initiative (in the United Kingdom) and The Government Performance and Results Act (in the United States). The slogan 'let managers manage' explains the approach that was taken by the adherents of the New Public Management doctrine. It states that in order to improve the quality of public services and reduce public expenditures, public officials must be granted a substantial level of operational freedom in order to perform their duties with maximum efficiency. Accordingly, their effectiveness must be assessed and praised not on the basis of proper following of administrative procedures, but on the final outcomes of their work. Therefore, the logic of performance substitutes the nomenclature of regulatory norms and procedures. Ethics of public policy must also to be transformed

35 See for example: John Shields and B. Mitchell Evans (1998) Shrinking the state: globalization and public administration "reform". Halifax, N.S.: Fernwood. 
in order to be able to accommodate market principles of services provision and treatment of citizens as customers.

The market principles of New Public Management demand public administrations to be accountable to the people in the first place, as the primary customers of services that these administrations provide. At the same time the logic of the political process in Russia emphasizes the top-down accountability within the bureaucratic hierarchy that extends to the top layers of the ruling political elite, being wrapped up in the form of a conceptual pyramid of power. This type of political relations is run by means of explicit regulations. Therefore, the combination of both - adoption of the new managerial model of government alongside reinforcement of the power vertical in Russia - may have been an important factor that affected the ways in which the reform of public administration has been implemented in the country.

Such a definition of the problem leads to formation of the goal of the dissertation as the analysis of internal (endogenous) and external (exogenous) factors ${ }^{36}$ that influence the process of reforming of public administration in Russia. Thus the project addresses one of the most controversial reforms in the post-Soviet history of the country. Complexity of contemporary political life in the country does not allow determining one major factor that dominates the process of reform. Instead, several factors indicate how the reform has been implemented.

${ }^{36}$ Under internal (or endogenous) factors the analysis understands parameters and characteristics of the system of government and the bureaucratic apparatus. Being the object of the reform, they also have an effect on the success of the reform. Consequently, external (or exogenous) factors are those that influence the conditions - political, economic, social, and cultural - under which the reform is being implemented. 
The major research hypothesis states that the given model of reform faces obvious difficulties in addressing the issues, both external and internal that affect the Russian officialdom. Therefore, it may be argued that the major hypothesis posits that the fundamental reason for failure of the reform of the Russian state apparatus is incompatibility of its NPM-based design and the general trajectory of political process in the country.

The proposed hypothesis connects two large vectors of political development. The overall political process is driven by the vertical, hierarchical integration of the political space. The reform of public administration, on the other hand, is designed with references to the concept that emphasized development of horizontal, intra-departmental connections and easing the vertical instruments of regulation. Evolution of the system of government since the start of the reform reveals an obvious conceptual conflict and leads to formulating the objective of the research as the analysis of the process of public administration reform aimed at revealing the causes of and factors that contributed to deviations from the initial goals.

\section{Theoretical frameworks}

The proposed research hypothesis is vested heavily in the contemporary theoretical outlook on the nature of governance and public administration. It also posits a particular research problem. On the one hand, Russia has a thousand-year long tradition of statehood. Over most of its history the state remained the dominant factor and the major driving force of change in the country. Obviously this put some constraints on the nature of public administration. This aspect of political-administrative culture cannot be ignored in assessing the current reform performance. On the other hand, the post-Soviet 
vector of political transformation places Russia in the cluster of transitional countries that perform large-scale modernization projects. Shortly after the dissolution of the USSR Russia joined a highly diversified pool of countries undertaking liberal democratic reforms. In the early 2000s Russia retreated, at least in part, from this direction towards building a more traditional type of polity in Russia ${ }^{37}$ that was named 'sovereign' ${ }^{38}$ or 'managed ${ }^{39}$ democracy. Therefore the conceptual aspect of the reform in Russia is placed in the core of the current research and a thorough discussion of the proposed theoretical framework is imperative.

The reversal of the political course that began in Russia with election of Vladimir Putin, questions not only the fundamental premises of the modernization and transition paradigms, but also, and perhaps, more importantly, the process of the reform itself. This revives the problem that was raised for the first time almost half a century ago by Samuel Huntington in his seminal article "Political development and political decay." seminal work initiated one of the most vigorous debates in comparative politics, namely about the superiority of institutional performance over economic liberalization. Huntington's argument was questioned by many distinguished scholars. ${ }^{41}$ Yet, the case of

${ }^{37}$ McFaul, Michael et. all. (eds.) (2004) Between Dictatorship and Democracy: Russian Post-Communist Political Reform. Washington: Carnegie Endowment for International Peace.

${ }^{38}$ Vladislav Surkov (2006) "Natsionalizatsiia buduschego" Expert. No.43(537).

${ }^{39}$ Gleb Pavlovskiy (2009) "'"Upravliaemaia" demokratiia, ili prosto opytnaia?" Russkii Zhurnal. (Online). [URL: http://www.russ.ru/Mirovaya-povestka/Upravlyaemayademokratiya-ili-prosto-opytnaya], (Accessed September 30, 2013).

${ }^{40}$ Samuel Huntington (1965). "Political development and political decay." World Politics, Vol. 17, No. 3., pp. 386-430.

${ }^{41}$ See for example: Barbara Geddes (1999) "What do we know about democratization after twenty years?" Annual Review of Political Science. Vol. 2., pp.115-144; or David L. Epstein et. all. (2006) "Democratic Transitions." American Journal of Political Science, Vol. 50, No. 3, pp. 551-569. 
Russia to a great extent supports it. Not completely abandoning the modernization trajectory, Putin's administration focused on solidification of the political-administrative space. However, in one particular instance of public administration reform, institutional reinforcement did not coincide with efficiency improvement.

As was stated earlier, Russian reform was well grounded in a contemporary theoretical vision of public administration. Major postulates of the Conception of Administrative Reform reflect the need to improve regulatory capacity of public institutions, on the one hand, and reduce government's penetration into the economic sphere, on the other. These goals dominate the discourse on public policy and administration and are present not only in public statements of politicians and experts, but also in the academic research in Russia, as well as internationally.

Therefore, this dissertation focuses on two dimensions that have been dominating the debates on public administration for at least fifty years. The first - the politicaladministrative dimension - refers to issues of governmental practices and regulations. It describes the level of operational flexibility that public officials are granted in order to perform their duties, as well as forms and means of promotion for their activities. There are two opposite maxims that constitute the administrative space - a completely regulated Weberian-style bureaucracy, on the one hand, and a maximally de-regulated managerialbased public administration, on the other. The second dimension refers to the degree of government's involvement in social and, more importantly, economic life. The two maxims here were institutionalized in the forms of political-economic conceptions of Keynesianism and monetarism. 
Although, as with any conceptual modeling, this 'regulation vs. deregulation' approach simplifies the real assembly of public administration theories; it nevertheless seems justified. The two dimensions mentioned above constitute a particular theoretical framework. There are two major features that also clarify the framework and contribute to its definition. One of the most fundamental features is conceptual separation of the public and private sectors. Among the earliest defenders of this approach may be named Ludwig von Mises, who argued that principles of cost-benefit analysis that are adopted in the private sector, are solely based on profitability. ${ }^{42}$ This principle could hardly be implemented in many areas of public administration.

The second feature is the necessity of distinction between the political and administrative functions of the state. The German scholar Max Weber added substantially to the discussion by developing the theory of rational bureaucracy. Weber recognized legal-rational principles as the basis of public governance. He argued for the necessity of a clear and rigid division between political and administrative functions within the government as far as they have different types of legitimacy. For Weber, political functions are based on the plebiscitary principles. At the same time at the core of the administrative ethos lie principles of efficiency and professionalism. Being excluded from politics, the bureaucratic apparatus is considered as the perfect provider of policies, an instrument of power held by others.

The political-administrative dichotomy is complemented by the debates over the size of government. Demarcation of zones of governmental authority inspired the battle of ideas that influenced the development of political economy in the 20th century. The

${ }^{42}$ Ludwig von Mises (1962). Bureaucracy. New Haven: Yale 
debates were driven by two groups of intellectuals inspired by the philosophical and political-economic doctrines of Friedrich von Hayek and John M. Keynes. Hayek argued that deeper penetration of the public sector into the realm of private life creates inevitable threats of over-bureaucratization and, as a result, ineffectiveness of a country in general. In reverse, Keynes argued that only a public sector that is based on the principles of scientific planning and effectiveness could foster the overall development of a particular state. Political-philosophical debates between these theories have created a scientific milieu within the reforms of public administration took place in many developed countries since the World War II. ${ }^{43}$

The concept of the welfare state contributed to the debate on the size of the government significantly. The quantitative growth of the state apparatus was supported by the argument that in the 20th century governments became active players in providing services in such spheres as education and science as well as public health and social security. That allowed it to outline traditional and new (contemporary) governmental functions. Although traditional functions (such as foreign security and defense, maintenance of law and order) pertained to the political realm, fulfillment of the contemporary functions, at the same time, demanded the government stepping deeper into the economic and social spheres.

These debates over the size of the government are complemented by the discourse on the zones of bureaucratic authority. In this regard, in late 1980s the New Public Management achieved doctrinal status, becoming the most influential approach to

${ }^{43}$ See for example: Daniel Yergin; Joseph Stanislaw (1998). The Commanding Heights: The Battle Between Government and the Marketplace that is Remaking the Modern World. New York, NY: Simon \& Schuster 
governance. NPM combined both the classical principle of separation of political and administrative functions in the government and the neo-conservative principles of noninterference of the state into the economy. Talking about managerialism experts pointed to the necessity of transition from the model of bureaucracy, oriented on servicing the needs of a political establishment, to the model of a 'responsive democracy'. ${ }^{44}$

Dominance of the managerial approach in the discourse on governance was supplemented by a considerable criticism and skepticism regarding the applicability of market principles to public issues. Scholars' concerns were mainly related to the deliberate limitation of the governing capacity of state to purely managerial issues. Neonormativists emphasized the importance of political-philosophical doctrines for actual public policy theories. In 1984 they issued the Blacksburg Manifesto that proposed "a refounding of public administration in the normative concepts of governance and constitutionalism and suggest[ed] that such a refounding [would] lead to recognition of the legitimate role of public administration in the governance." ${ }^{45}$ The Manifesto describes public administrators as "constitutional officers" who are "uniquely placed in the policy process, first, to search for the public interest... as an ideal and a process; and second, to guide policy in the direction that is indicated by that search., ${ }^{, 46}$

Summing up it may be argued that the mainstream theoretical contemplations on the present and future conditions of government in one way or another refer to the managerial revolution and the New Public Management movement, giving it almost a

${ }^{44}$ See for example: Gerald N. Rosenberg (1993) "The Real World of Democratic Community" in John. W. Chapman and Ian Shapiro (eds.) Democratic Community: NOMOS XXXV. New York: New York University Press., pp.228-258

${ }^{45}$ Gary L. Wamsley et.al. (1990). Refounding public administration. Newbury Park, Calif.: Sage Publications, p.18

${ }^{46}$ Ibid. 
paradigmal status. By the end of the millennium the doctrine of NPM achieved its maturity. Although, the paradigmal status of the doctrine was contested by rather powerful intellectual alternatives, such as the neo-weberian state, it still remains the mainstream approach in theory of governance and forms most of traits of the outlook of the ideal type of state.

There are several justifications of this argument. First of all, most countries that have performed reforms in the sphere of public administration unilaterally move in a single direction: from a more holistic bureaucracy that used to be involved in different forms of public activities, towards a more customer oriented officialdom. Secondly, the conception of the welfare state remains another important yardstick for the reformers. Since its adoption as a plausible form of governmental organisation, at least among the OECD countries, the concept has retained its topicality. This led to modification of the rather radical early 1980s idea of "shrinking the state" to more reasonable debates about improving efficiency of governments by introducing new administrative processes. Thirdly, the approach is supported internationally as the most plausible alternative in performing modernization of public institutions. Powerful donors such as The World Bank and The International Monetary Fund in every way possible urge reformers to head for flexible and compact governments. These factors, to greater extent influenced the choice of the model and the program of reform of public administration in Russia.

\section{Methodology \& research design}

The stated objective of the research - analysis of the process of the reform of public administration and establishment of factors that contributed to its setbacks demands a multidimensional analytical perspective. From the epistemological point of 
view the dissertation estimates how two concepts-'power vertical' and 'new public management' - interact with each other through practice. Such a perspective determines the primary research focus on the process of the reform that becomes the subject of the research (e.g., the arena where ideas are being apprehended, transformed and utilized). The research focuses on the process of transformation of theoretical and ideological postulates into a chain of policies and reform measures, as well as estimating the outcomes they have produced and the effects they have had on the system of government and other adjacent spheres of public life. The emphasis on causality in the analysis determines employment of two methods of conducting the research: the process-tracing method, and Max Weber's ideal types approach.

Process-tracing is a method of empirical analysis aimed at exploring causal inferences. This "method attempts to identify the intervening causal process - the causal chain and causal mechanism - between an independent variable (or variables) and the outcome of the dependent variable. ${ }^{47}$ It is different from statistical inferential techniques by virtue of focusing not on causal effects, but rather on causal mechanisms. Out of three different forms of process-tracing methodology - theory-testing, theory-building and explaining outcomes - the dissertation utilizes the last one. ${ }^{48}$ It is aimed at crafting "a (minimally) sufficient explanation of the outcome of the case."49

Process-tracing methodology helps the researcher to focus on the existing evidence within the case being studied. Considering public administration reform as a

\footnotetext{
${ }^{47}$ Alexander L. George; Andrew Bennett. (2005). Case Studies and Theory Development in the Social Sciences. Cambridge: MIT Press, p. 206-207.

${ }^{48}$ Derek Beach, Rasmus Brun Pedersen (2013) Process-Tracing Methods: Foundations and Guidelines. Ann Arbor: University of Michigan Press., p.3

${ }^{49}$ Ibid., p.3.
} 
research case, the researcher recognizes its socially-constructed nature. ${ }^{50}$ As a social construction the plan of reform contains ideational and practical aspects. First of all the reform was designed according to the projected vision of the reformers regarding the future structure and role of the state apparatus. This vision was based on a set of values and theoretical projections (New Public Management in this particular instance). In order to achieve the proposed objectives the reform project established a sequence of measures. By means of these measures the ideational construction was to come to fruition. The process-tracing method provides analytical tools that allow the researcher to carefully reconstruct the chain of events within the case of public administration reform, focusing on causal aspects of interactions between them. Therefore, the methodology helps investigate reformers' intentions and the initial plan of reform as well as to analyze deliberate and occasional deviations from it.

The way the reform has been executed leads to a conclusion that the reformers adhered to the technocratic approach. They emphasized the institutional dimension of public administration. That explains why the structural changes in the architecture of public administration outperformed transformation of functional capacities of public institutions. The reform began with establishment of a new system of federal public institutions. All organizations were reorganized into three clusters, according to the major functions they were designed to perform. Apparently, the introduced changes did not produce the expected results.

${ }^{50}$ Andrew Bennett and Jeffrey T. Checkel (2012). "Process Tracing: From Philosophical Roots to Best Practice" 
Similar the rationality-based approach, as it was carefully described in Max Weber's writings ${ }^{51}$, can be used for the analysis of the reform process as well. Weber's ideationally driven conception of 'ideal types' posits that researchers are capable of modeling abstract, yet purely rational, conceptual models of social organizations. These models represent systems as they must be constituted in order to perform with maximum efficiency. In this sense they are not embodiments of real models, but rather utopian constructs, as far as only necessary causal relations are included. The method further involves comparison of the real social objects to these relevant ideal constructs in order to determine how exactly and to what extent reality differs from the rational ideal models.

The methodology of the ideal type approach may be stated as the general, overarching principle of the analysis of the process of public administration reform in Russia. First of all, it allows the researcher to focus on the factors that contributed to the reform setbacks, and therefore led to deviation from the ideal-type model. Secondly, its validity was reinforced by the fact that the reformers adopted a technocratic approach. The reform was designed rationally and in accordance with the current trends in theory of public administration. Therefore, the key documents of the reform, represent the forms of ideal type themselves, given the fact the way they were crafted based on the New Public Management model, as they understood it. Analyzing the deviations from the initially proposed plan should lead the researcher to establish causes of these deviations.

The actual study of these causes would demand including into the analysis various spheres of governance that were affected by the reform. This in turn would demand using a versatile set of research tools, both conceptual and empirical, as well as qualitative and

${ }^{51}$ Edward A. Shils and Henry A. Finch (eds.) (1949). Max Weber on the methodology of the social sciences. Glencoe: Free Press. 
statistical. In this respect, the actual methods of analysis are issue-specific. Such an approach falls well within Feyerabend's relativistic epistemological criteria and is supported by the existing eclectic methodological tradition. Marshall Dimock mentions public policy as a multidisciplinary field that synthesizes latest developments from different disciplines. ${ }^{52}$ This idea was supported by Frederick Mosher, who even compares the field of public policy with medicine. Both disciplines are eclectic and have been established on the bases of some general disciplines. Like medicine, which demands knowledge of physiology, chemistry, physics, and so forth, public policy adopts knowledge and methods of research developed in sociology, economics, psychology, conflictology and others. ${ }^{53}$ And in reverse, having knowledge in these maternal disciplines does not necessarily give you proficiency in public policy.

In return, necessary epistemological flexibility puts extra constraints on the design of the research, demanding proper definitions of its object and subject, as well as goals and necessary tasks. Thus, the given dissertation considers the federal public administration (i.e., its institutions, formal-legal framework, as well as personnel) as the primary object of research. As the major research hypothesis states, the major factor behind the misfortunes of the reform would be disparity of two major vectors - the vertical political vector and the proposed horizontal administrative vector. However, this hypothesis is general and demands operationalization. Conceptual inconsistency may be understood as a result of changes from the benchmark approaches that were introduced into the national conception of reform during the preparatory stage. Deviations might also

\footnotetext{
${ }^{52}$ Marshall Dimock (1978) Philosophy of Administration. N.Y., p. 21.

${ }^{53}$ Frederick C. Mosher (ed.). (1975) American Public Administration: Past, Present, Future. The Univ. of Alabama Press, p. 27.
} 
be the result of mishaps during implementation of the reform. The fact that the bureaucratic apparatus, required to modernize itself, might create excessive traction or even shirk responsibilities is potentially a quite significant factor that could contribute to the reform misfortunes. Also, the managerialist ideology was not familiar to the mentality of public officials and they might be reluctant adopt it. Therefore, it is possible that the NPM-based measures of the reform were the major factors that contributed to the overall failure of the public administration reform project. In order to thoroughly research the mentioned aspects of the reform a set of tasks must be accomplished.

First of all, the concept of 'power vertical' must be analyzed. Power vertical is a symbolic representation of the dominant aspects of contemporary political processes in the country. It was implemented in a series of reforms that solidified the political space in the country in the first years of the $21^{\text {st }}$ century. The ways power vertical dominates the political discourse are broad and versatile, therefore their assessment should elucidate its major characteristics.

The second task would be the analysis of post-Soviet development of public administration in Russia. This endeavour should assess whether the reform of the state apparatus was needed. The need for reform, as well as its urgency, is one of the key point of this dissertation that argues that the reform of public administration was inevitable. Therefore, the condition of the sphere of public administration prior to the reform must be assessed. Moreover, this analysis must point out the major tension points that impeded public officials from properly executing their duties.

A third task of the dissertation would be reviewing the conceptual and theoretical dimension of the reform. The reform was based on a well-developed New Public 
Management theory that achieved paradigmal status during the 1990s. Almost every country that performed modernization of its public service was to a certain degree addressing issues and adopting methods, developed within this paradigm. Therefore, a proper analysis of major postulates of NPM, and the ways they were addressed in the conception of the reform in Russia is an important task for the current analysis.

As one supplementary hypothesis suggests, deviations from the well-developed conception could occur during the stage of reform implementation. Therefore, it is important to investigate how the reform was implemented, in what stages, and what immediate results were, as well as long-term consequences of introduction of new governance methods.

Finally, the dissertation must analyze in great detail the actual contribution of the New Public Management approach to the reform of governance. Russian reformers chose to adopt not the entire managerial ideology, but separate, however very significant, instruments and administrative practices. Therefore, it is important to assess efficiency of these NPM-based methods of governance within the Russian political-administrative tradition.

\section{Contribution to the discipline}

This dissertation takes a peculiar academic perspective on the problems of governance reform in the Russian Federation. Understanding limitations pertaining to the general transition-studies approach developed as an overarching explanatory framework for studying reforms in post-Soviet and post-socialist countries, this work elaborates on a new and rather unique conceptual alternative. The conceptual framework is built around the discrepancy of the vertical vector of political process that pertains to the political 
culture of some nations and applied theories of modernization of governance and political sphere that stress the horizontal vector or political communications.

The approach creates a new perspective on political reforms in Russia and on the reform of civil service and public administration in particular. This perspective suggests that deviations and mishaps of the reform implementation lie in the conceptual sphere in the first place. Ideology of reform projects that the ruling elites has attempted to implement differ substantially from the political culture that they also favour. At the same time, the level of adaptation of these projects is not sufficient to overcome potential negative effects that are created in the process of reform. This also does not allow the reformers to tie together ideologically identical projects into a unified network, establishing a sort of grand project of reforms. Separate reforms are being transformed in the process of their implementation, sometimes even changing perceptions of their final objectives.

This can be observed in case of many reforms performed in Russia after the collapse of the Soviet Union, beginning with the Constitutional reform and installation of the super-presidential form of governance and ending with contemporary reforms of the pension system and monetization of social benefits. The reform of public administration is the most evident case of this conceptual inconsistency. Focusing on it, this dissertation avoids traditional explanations of mishaps of Russian modernisation that are often referred to corruption and institutional underdevelopment (stressing primarily the civil society). Instead, corruption becomes not the primary cause of the reform's failure, but rather a dependent or, at least, collateral factor. The approach also provides clues to 
potential remedies that may be helpful in fixing the gaps between theory and practice of reform implementation.

Beyond the primary contribution there are other possible implications of this research. First of all, the dissertation contributes to better understanding of the New Public Management paradigm. Being used worldwide, the paradigm produced different outcomes in different settings. Results differ across the political regimes and political cultures. The Russian case contributes to understanding of challenges of managerialism in transitional and to some extent authoritarian countries.

\section{Chapters' outline}

The dissertation consists of the Introduction, six Chapters, the Conclusion, the Bibliography and Appendices. Each chapter is devoted to discussion of a particular objective of the dissertation. The logic of research demands going beyond directly focusing on aspects of the reform and addressing changes in the political process of the country as well.

Chapter I discusses the political process in Russia during the presidencies of Vladimir Putin and Dmitry Medvedev. The election of Putin in 2000 signified a radical change in the course of the political process in the country. From the very beginning Putin proposed a program of reform that retracted Russia from the traditional transition path to democracy. Other ideologemes were proposed instead. The condition of political process in Russia in the first decade of the $21^{\text {st }}$ century has been described elsewhere ${ }^{54}$ as

${ }^{54}$ Although the 'social contract' approach has never been mentioned officially, nor it has
become popular in the academic sphere, the ideologemme remains its popularity as a
media and public sphere aphorism. In this regards, the concept has been used by public
figures and journalists. See for example: Oleg Kashin (2013) "Izderzhki obschestvennogo
dogovora."
Slon
[URL: 
the existence of a sort of "social contract" between Vladimir Putin himself and the supporting political elite on the one hand and the people of Russia, on the other. The social control involved a substantial reduction of liberal-democratic freedoms in the polity, which was compensated by enhancement of political stability and steady economic growth.

The proposed vector of strengthening the executive authority was accomplished quite quickly and by the end of 2004 the Kremlin was able to solidify the political space and enhance the power vertical. The processes of 'bringing the state back in' included a variety of efforts in several different aspects of political life: from constraining the regional politics and electoral process to substantial penetrations into public life and enhancement of regulations over political movements and non-governmental organizations.

All this significantly reshaped the political process in Russia and inspired vigorous debates on the nature of 'Putin's Russia'. The new arrangement of political institutions and processes formed the milieu for the reform of public administration. Moreover, the latter was envisioned as the cohesive factor in the large-scale sociopolitical and economic modernization of the country. Therefore the process of political reform in Russia is theorised in the Chapter as the 'conceptual pyramid of governance'. This approach allows uniting all political reforms - from the reform of federative relations to the municipal reform - in the same analytical model. Moreover, the conceptual pyramid of governance corresponds with another political metaphor of 'power

http://slon.ru/russia/izderzhki_obshchestvennogo_dogovora-928681.xhtml] (Accessed July 31, 2013). See also: Irina Voitseh (2013). "Narod i Putin: lish' by ne bylo voiny..." Utro.ru (Online) [URL: http://www.utro.ru/articles/2013/03/05/1104984.shtml] (Accessed July 31, 2013). 
vertical'. The Chapter is focused on the process of enhancement of the vertical, a predominantly top-bottom political vector, and traces its instalment through several blocks of reforms. These blocks are: 1) the reforms of federative relations that include: the reform of the federation council, introduction of seven (later eight) federal districts and the institution of presidential envoys, and, finally renunciation of gubernatorial elections; 2) reform of electoral process; 3) the political parties reform; 4) introduction of 'sovereign democracy' and reforms of the civil sphere.

Chapter II is devoted to the issues of post-Soviet public administration and public service. After the collapse of the Soviet Union, and especially after the 1993 Constitutional Crisis, the institutional aspect of public administration in Russia was changed quite substantially. A new powerful state institution - the Presidential Administration - was established. With its appearance was created a new and quite significant centre of power on the Russian political landscape. The Chapter focuses on how institutional changes in the Russian state apparatus affected political-administrative processes. The Presidential Administration has become a very powerful alternative to the government within the executive branch. The chapter also analyzes the process of functioning of the government prior to the current reform. It is shown that its structure and composition were often dependent on the current political situation; and the government did not act as a unified and solid institution. Often substitutions of heads of the Cabinet contributed to it substantially. Regardless of substantial institutional transformations within the executive branch during the 1990s, the political-administrative development of the executive branch was predominantly incremental. Moreover, dismissing communist ethics and ideological background new political elites did not 
provide public officials with new ideological landmarks. This factor, alongside poor economic conditions, substantially affected the efficiency and ethics of Russian public officials, especially on the lower and middle levels.

Analysis of public service in the chapter is separated from the discussion of institutional changes. The chapter addresses one of the most common and perhaps universal discourses on public administration, that is, about the size of its bureaucratic apparatus. It has become a common trend among the politicians to criticise the growing size of public services, and Russian leaders adhere to the rhetoric as well. The chapter assesses the quantity of public service in Russia and compares it to the most OECD countries, arguing that the size of the government should not be considered the major concern of the reformers. Instead, qualitative parameters of public service must be given priority, and especially its modus operandi, plagued by the Soviet legacies and especially by the nomenclatural principles of cadre politics.

The chapter concludes that the reform was indeed imperative because incremental changes had led to institutional inconsistencies and deterioration in the socio-economic and demographic characteristics of public administration as a result of the first postSoviet decade of liberal reforms.

Chapter III discusses the theoretical framework of the reform, as well as conceptual alternatives available to substitute the NPM model. It focuses primarily on current developments in the theory of public policy and administration. The chapter is devoted to answering the question of whether the selection of the model of reform was justified in the given circumstances. It also considers the level of development and applicability of alternative conceptions. 
In the past several decades a plethora of theoretical approaches to public policy and governance been developed. In order to systematize approaches the dissertation proposes an analytical matrix with two dominant vectors. The political-administrative vector stretches between the two antipodes: fully regulated classical ideal-type bureaucracy and flexible new public management officialdom. The political-economic vector places countries in the continuum between the expanded welfare state that is deeply involved into economic life and shrunk and compact welfare state that minimises its activities related to provision of public goods relying heavily on private sector technologies of management.

It is posited in the Chapter that the majority of contemporary public administrations are located within the created two-vectors matrix between the maxims. Obviously, the current discourse on the future of governance perfectly fits in the proposed scheme; and the matrix possesses explanatory power to discuss the majority of modernization attempts.

Numerous contemporary studies added to the notion of advantages and limitations of the NPM concept. Although comparative studies show that almost all countries that recently undertook modernization of their administrative systems in some way or another used NPM technologies. Russia was not excluded from the trend. Yet, the Russian program of reform was somewhat different from those proposed and implemented in some advanced countries that pioneered such reforms. Thus, Chapter III also scrutinizes the program documents of reform in Russia and assesses the level of adherence of them to the mainstream managerial ideology of modernization of public administrations. 
Chapter IV is fully dedicated to the process of the reform of public administration in Russia. The chapter is aimed at finding factors that influenced delays and backlashes. Therefore, Chapter IV not only carefully monitors each of three stages of the reform, but also assesses performance of public administration at each stage.

Public administration reform was conducted in three consecutive stages. Each stage had its own goals; and these goals differ substantially from one stage to another. At the first stage introduction of a new three-layer institutional framework was the major objective, as reformers believed that proper structure is imperative for further progression of the reform. The second stage was aimed at introduction of new principles of administration on the basis of the chosen managerial ideology. The third stage concentrated on fight with corruption, and improvement of accessibility of public services. Major innovations introduced at each stage are discussed in the chapter, which concludes with analysis of results that were achieved during the first decade of the reform. Evidence clearly reveals that the most aspired objectives of the reform were not achieved. Moreover, in some instances the reform contributed to even further deterioration of the quality of the government's functioning.

Chapter V discusses the civil service reform in Russia. The Conception of the reform of civil service in Russia was issued in August 15, 2001, almost two years before the President signed a Decree that launched the public administration reform and almost four years before the latter gained its own conceptual formalization. More importantly, different administrative bodies were assigned to conducting each reform. The reform of the civil service was administered by the Presidential Administration, whereas the public administration reform was assigned to the Government. 
It is the approach of this dissertation to consider both reforms as parts of a largescale reform of government in Russia. Therefore, the logic of analysis of the reform of civil service follows that of the reform of public administration. The dissertation discusses and assesses impacts of legal and organizational innovations that were introduced in the course of the reform. The modernization of civil service included clarification of the legal status of state service in general and state civil service in particular. Hiring procedures as well as bureaucratic code of conduct were also modernized. However, the chapter shows that the performed modernization did not improve the quality of work of public officials, notwithstanding a substantial increase in budgetary spending.

The review of the reform process prompts further investigation into the subject matter of managerial reform. It is conducted in Chapter VI of the dissertation. The research hypothesis assumes that it will be the NPM-based innovations that were not able to function properly within the vertically integrated hierarchical political system. As it follows from the analysis of the conceptual premises of the public administration reform, Russia not only used a fundamentally different approach to the reform in order to address peculiarities of the political system; it also was very selective in its choice of managerial measures. However, it decided to adopt the most quintessential NPM measures, such as performance-based management and budgeting, outsourcing, and contractual procurement of governmental needs.

In order to assess the assumption stated in the hypothesis these three most important cases of NPM-based reform measures undergo an in-depth analysis in the chapter. The analysis reveals that in some instances, like in the case of performance 
management, the reform was performed only decoratively; in other instances technocratic attempts to install modern administrative technologies resulted in frenzied corruption and are going to be either revoked, or substantially modified. The results of these case-studies clearly indicate failure of the New Public Management project in Russia, at least under current political circumstances.

The results of the decade-long reform of public administration reform are summarized in Conclusion. Although the last stage of the reform is still going on while this research is being accomplished, it seems valid to assess the dynamics of performance of Russian public administration. The third stage is scheduled to be finalized by the end of 2013 and the majority of measures have already been implemented. Throughout the dissertation it has been made clear that regardless of some situational successes, in general, the reform may be perceived as a failure. It was even not able to improve its performance even with respect to the indicators that were chosen by the reformers themselves. By some other independent accounts the reform could not be considered successful either.

The dissertation is aimed at resolving a puzzle how the reform that was supported from the very top of the political establishment that was based on the conception with paradigmal status and that had a thoughtful design ended up producing minimal changes. The research concludes that, apart from situational mistakes and negligence, the major reason of the reform failure was its conceptual incompatibility of the new public management model of reform and the dominant vertical vector of political process. In the course of the reform, public service was not able to reorient itself from servicing the patron to servicing citizens. Besides creating sufficient infrastructure for the reform, such 
as the new three-layer system of governance little effort has been made so far to enhance accountability of the officialdom to the civil society. Attempts to emphasize the institutional aspect with expectation for the following adjustment of the functional capacity of public administration did not help either.

The dissertation concludes that regardless of the level of theoretical elaboration, the managerial aspects of governance may not function properly in societies with underdeveloped and depressed civil societies, even with existence of political will to reform and substantially solid executive institutions. The solution to the problem may be seen as hackneyed, but taking into account the reform attempts in other non-mainstream countries, it nevertheless refers to either promotion of the liberal reforms, or substitution of the theoretical model of NPM. 


\section{Chapter I. Public Administration, Public Policy and Political Process in the Russian Federation: building the vertical of power.}

\section{Introduction}

Public administration has always been an arena of special attention when the question of the reform arose. The personification of the political process in Russia and the top-down vector of dynamics of political and administrative relations have made the central government the most important agency for scrutiny. The Russian state service undergoes fundamental transformations almost every hundred years. Regular state service as a specific form of employment was initiated in Russia in the early sixteenth century under the Prince Vassilii $3^{\text {rd }}$. However, its institutional arrangement, which was based on the departmental principle of the system of organs of public service, was obtained under the Moscow Tsar Ivan $4^{\text {th }}$, 'the Terrible'. A revised code of laws ('Sudebnik') from 1550 established the system of public offices (prikazy) based on the sectoral principle. This system existed in Russia for more than 150 years.

The next era of the Russian state service began with establishment in 1717 of collegias -governmental departments of early imperial Russia. This system was introduced by Emperor Peter $1^{\text {st }}$ and one of its basic features was the collective form of decision making. It replaced the already outdated system of 'prikazy'. By that time these old agencies suffered from ambiguities concerning their authority, functional and operational capacity. In some instances functions of some agencies were overlapping. Collegias further improved the sectorial principle of governance when governmental duties were separated into a range of crown offices responsible for various aspects of a country's life: from defense and foreign relations to trade and finance. 
The Collegial system of government was also replaced in 1802 by the ministerial system of state service under Emperor Alexander $1^{\text {st }}$. Introduction of ministries into governmental organization is remarkable because since then, institutions of executive power have almost always had the same functions and status. The principle of undivided authority of a minister was put into the core of the system. Another crucial feature, inherited by contemporary offices, was the definition and demarcation of powers and duties. For the ministries established in 1802 these documents were called Instructions. Modus operandi of the contemporary governmental bodies is regulated by the so-called administrative regulations ('administrativnye reglamenty').

With the victory of Bolsheviks in 1917 the previous system of ministries was replaced by the system of People's Commissariats. Besides replacing the names of the administrative bodies this system inherited the spirit and principles of work from the ministerial system. The list of Commissariats was written in the 1918 Constitution, which certainly improved the legal status of the new system of state administration. This system existed untouched for nearly thirty years and was replaced again by ministries in 1946, shortly after World War II. The communist political system and the command economy determined the structure, as well as the quantitative and qualitative parameters of the government during the Soviet era. The government had a very complex structure, including over 50 various types of ministries and state committees. This system existed until the dissolution of the Soviet Union.

Obviously, such a system was too excessive for a country with a market economy. However, post-Soviet Russia inherited the governmental structure from its predecessor Russian Soviet Federative Socialist Republic (RSFSR) - for the period of initial 
transition in 1991-1993. Its activity was mainly regulated by the Law "On the Council of Ministers of RSFSR” from August 3, 1979.

A new era in development of Russian public administration began in 1993 with adoption of a new Constitution of the Russian Federation. For the next few years the government of the Russian Federation underwent several reshuffles, some of which were quite substantial. There were seven heads of government, both official and acting, during Boris Yeltsin's presidency. Vladimir Putin in 2000-2008 replaced three prime-ministers before undertaking the castling and becoming the head of government himself for the entire presidential term of Dmitriy Medvedev. The return of Putin to the Kremlin in 2012 and appointment of Medvedev as the Prime-Minister totalled the current count to a dozen.

Almost every substitution of the prime-minister signified noteworthy changes in the politics of the cabinet. Federal ministries and other central agencies were subjects of transformation as well. Changes, however, occurred only within the higher strata of bureaucracy. Lower levels of the government as well as its institutional arrangement were subjected to changes quite infrequently. Therefore one may argue that although the government showed significant flexibility in manpower policy and was easily adjusted to the given political realities, its internal configuration was much more conservative. Lower levels of the bureaucratic apparatus retained their institutional, professional and ethical characteristics. This undoubtedly decreased effectiveness of proposed policies. It would be fair to assume that the current reform of the state apparatus is probably the first attempt to transform Russian bureaucracy since the collapse of the Soviet Union. 
A few attempts to introduce changes to the sphere of public administration occurred shortly after the adoption of the new constitution of Russia in 1993. A complex system of political relations in the country that was reflected in the document, and demanded normalization and streamlining of governmental functions. Presidential Decree No. 1969 of October 3, 1994 established the major principles of appointment and election of public officials at the federal, regional and municipal levels. ${ }^{1}$ In July 31,1995 , federal law \#119 "On the foundation of civil service in the Russian Federation" was adopted. These and other changes were generally aimed on adjusting the given system of bureaucracy to new, post-Soviet political, economic and social realities.

Speaking generally, these changes were fragmented and responsive in nature. They were mainly reactions to the challenges and demands from various spheres of public life in Russia. It is agreed that all measures undertaken prior 2004, when the new system of public administration was introduced, were not systematic or progressive. ${ }^{2}$ They also outlined the necessity for a more substantial transformation of the system of public administration in order to suit the goal of comprehensive modernization of Russia. Such changes were proposed by the president on July 23, 2003 in his decree No. 824 "On arrangements regarding the implementation of the administrative reform in 2003-2004".

The reform of public administration followed a collection of measures undertaken by Vladimir Putin shortly after he took office. These measures affected existing relations in almost all spheres of public life. This chapter focuses on this block of political reforms.

\footnotetext{
${ }^{1}$ Decree of the President of the Russian Federation No. 1969 from October 3, 1994 "O merakh po ukrepleniiu edinoi sistemy ispolitel'noi vlasti v Rossiiskoi Federatsii." Sobranie Zakonodatel'stva Rossiiskoi Federatsii 1994 No.24.

${ }^{2}$ See for example: Vishniakov, V.G. (2011). "Administrativnaia reforma: 15 let poiskov kontseptsii”. Zakonodatel'stvo i ekonomika. No.7
} 
Transformations of the political landscape in Russia that occurred since 2000 can be presented in the form of a 'conceptual pyramid'. This theoretical outlook is enhanced by the fact that political development in the country was put in the ideological framework of the 'power vertical' doctrine. This chapter discusses the formation of the new principles of governance under these concepts. It is argued that due to the volume, radicalism and scope of the political reforms, which were undertaken by Vladimir Putin and his allies, the doctrine of vertical of power must be considered as the systemic factor in further analysis of the reform of public administration. Also this conceptual pyramid approach represents a convenient and accurate model for theoretical generalization of versatile reforms in the country.

These scholarly generalizations are nevertheless very well grounded in the history of the political process in Russia. They are not merely ideational abstractions. The need for reinforcement of power of the federal center was dictated by events of recent history. Thus, the concept of power vertical was introduced by acting politicians and not by the academic community. In order to show how these concepts became dominant forms of theorization about the political process in Russia this chapter will not only discuss and analyze their crucial aspects but also will place them in the political-historic context.

This chapter focuses on these two aspects of political reforms in Russia, namely the conceptual pyramid and the power vertical. The following pages will present a detailed outlook of these concepts and assess their significance for analyzing the public administration reform in Russia. 


\section{Contemporary reforms}

A new era of development of the Russian state can be paralleled with the beginning of the presidential tenure of Vladimir Putin. The second Russian president announced the need for quite remarkable political transformations at the beginning of his first term in the early 2000s.

In his programmatic article "Russia on the Edge of the Millennia," Vladimir Putin, then prime-minister and acting president of Russia, outlined major principles around which he would be going to build his policies if he were elected. He mentioned achievements and deficiencies of both: the Soviet period and the first ten years of the post-soviet development. Furthermore, he outlined stability as the major prerogative of his political reforms. ${ }^{3}$ Vladimir Putin tied stability with impossibility to continue 'social experiments'. The latter he explained as "transferring onto the Russian soil abstract models and schemes taken from foreign textbooks. ${ }^{, 4} \mathrm{He}$ spoke of a unique Russian path of modernization; and this idea of exclusiveness of the path of national development would be the cornerstone for many political transformations that would occur in the country in the following ten years following the publication of this article. He also spoke of an 'organic fusion' of principles of democracy and the market economy with Russian culture in general and the political process in particular.

Among the primordial values of Russian culture Vladimir Putin emphasized is statehood ideology (gosudarstvennost'), by which he meant the importance of institutions of the state in the Russian political mentality. This was later developed into the idea of the strong state - a kind of conceptual framework of all political reforms performed by

\footnotetext{
${ }^{3}$ Putin, Vladimir. "Rossiia na rubezhe tysiacheletii," Nezavisimaia gazeta, № 245 (2061), December 30, 1999.

${ }^{4}$ Ibid.
} 
the president in 2000-2008. According to this conception the state must be more deeply involved in the process of economic and social development of the country. Vladimir Putin saw the state as "an effective coordinator" that not only mediated different interests and performed necessary regulatory functions, but also fulfilled functions of strategic planning. According to the article, implementation of such policies is not possible without structural and functional changes in the executive branch of power. Outlines of the upcoming public administration reform were presented in this document. Vladimir Putin stated that "keys to the renaissance and ascent of Russia are in the state-political sphere". ${ }^{5}$ Russia needs a strong state; and in order to achieve such a condition, deep and broad transformation of the sphere of governance in the country with the primary focus on the executive branch of state is needed, he argued. Rationalization and optimization of the state apparatus, effective manpower policy, as well as the introduction of performance budgeting and measures to fight corruption - all these aspects were mentioned in one of the first policy documents proposed by the future president of Russia. This allows us to conclude that the reform of public administration was part of the core agenda of policy transformations that Vladimir Putin wanted to introduce should he be elected.

\section{The conceptual pyramid of governance}

The political reforms in Russia were organized around a central objective, which aimed to considerably reshape the political process, particularly in order to improve its predictability and manageability. These reforms may be stratified into three different layers within a conceptual pyramid. The top of the pyramid includes measures to reform federative relations in the country. The complex nature of inter-regional relations was the

\footnotetext{
${ }^{5}$ Ibid.
} 
root of many complications and even instability of the political process in Russia during the 1990s. Generally speaking, the block of federative reforms proposed by Vladimir Putin reflected a clear path dependency and correlated with the historic tradition of the evolution of the Russian state. It can be argued that the transformations carried out are deeply rooted in cultural attitudes and perceptions of the state by the majority of Russian people. Four critical features of early Russian federalism explain the difficulties of transition from communism and modernization of the country, which are: federative asymmetry; the national-territorial principle of organisation of the federation; the complicated practice of bilateral treaties; and the so-called hierarchy 1:89 ${ }^{6}$. All these features were deliberated and addressed in the reform of the federative relations during the early 2000s. These reforms are crucial for building the power vertical and deserve considerable analysis. Furthermore, they are essential for further allocation within the conceptual pyramid of the block of public administration reform as these two layers are deeply intertwined and show mutual effects on each other.

A complex of reforms aimed at transforming the state apparatus is placed in the middle of the pyramid. As was mentioned in many speeches by state officials, as well as in commentaries made by academics and experts, both the institutional and the functional characteristics of the Russian bureaucracy, do not match the goals of political, economic and social modernisation of the country.

Transformations of the state apparatus included administrative and civil service reforms that started in 2003 and are still ongoing with various levels of success. Their

${ }^{6}$ The hierarchy 1:89 explains the peculiarity of the federative relations in Russia, where all governments, both the federal and regional ones are considered as separate units and the federal government is positioned against each region and establishes relations with each and every of them independently. 
quantitative and qualitative characteristics will be discussed in detail in the following chapter. However, it is important to mention here that these reforms were scrupulously designed by a group of state officials and think tanks in order to overcome legacies of the Soviet regime, as inherited in the modern state apparatus and most especially prevalent in its manpower aspects. Low salaries, insufficient educational standards, lack of transparency, and the experience gap are the major critiques mentioned with respect to the public administration in Russia. ${ }^{7}$ The reform of the state apparatus included two aspects. First of all, contemporary Russian government had to adjust its organizational structure in order to meet the criteria of institutional optimisation. Secondly, public/civil service had to fully adjust itself in order to be efficient.

At the bottom of the 'conceptual pyramid' one may see a specific political reform that was designed to balance the transformation of federative relations and improve grassroots politics. The reform of local self-government was supposed to increase public involvement in the political process. Also, it was designed to avoid unnecessary centralization of the decision-making processes at the central level as this inevitably leads to over-bureaucratization of governance and a significant decrease of efficiency. The reform of local self-government in Russia, launched full scale in 2006, was designed to delineate 'zones of authority' and responsibility between institutions of the state and local (municipal) governments. After the abolition of gubernatorial elections in 2004 the vertical of executive power spread to the regional level. Indeed this municipal reform might be seen as the revival of a grassroots political tradition in Russia. Effective local self-governance, at least in theory, was seen as a necessary initiative that would prevent a

\footnotetext{
${ }^{7}$ See: Barabashev A., Straussman J.D. (2007). "Public Service Reform in Russia, 19962006." Public Administration Review, Vol. 67, issue 3 (May-June), pp. 373-382.
} 
return to the Soviet practices of governing where all decisions were centrally planned and local authorities had to only implement them. Indeed such a mode of management has shown its ineffectiveness as it is not possible for the federal or even regional authorities to foresee all nuances and needs that emerge on the local level, especially if the need for rapid and effective responses arises. Therefore, some experts saw revival of independent municipal governments as a real alternative to the vertical of power. ${ }^{8}$

The last years of existence of the Soviet Union were signified by active separatist movements in its republics, known as the 'parade of sovereignties'. The Russian Federative Republic (RSFSR) - the only federative republic within the federative state suffered from its own 'parade of sovereignties'. The first president of the country, Boris Yeltsin, in his battle with the Soviet (Communist) political elite and personally with president of the USSR Mikhail Gorbachev, tried to get support from regional political elites within RSFSR, thus pronounced the famous formula that regions of the republic can "take as much power as [they] can swallow". " Within several months following this remarkable speech, many autonomous republics within the RSFSR issued declarations that proclaimed state sovereignty.

However, after the collapse of the Soviet Union and creation of a new state named the Russian Federation in 1991 such centrifugal processes were put under restraint and all but two regions (Tatarstan and Chechnya) signed a new federative treaty that significantly reduced opportunities of the regions to exercise de-jure independence.

\footnotetext{
${ }^{8}$ See for example the discussion of experts: "What are political and economic risks of local self-government" that took place in the Liberal Mission Foundation on April 3, 2003. The transcript of the discussion is available on-line at: http://www.liberal.ru/articles/cat/976 (retrieved on May 10, 2011). ${ }^{9}$ Izvestia, August 8, 1990
} 
However, partially as a result of the populist politics of early 1990s, the Russian Federation had a very complex, multilayer federative structure (known as 'asymmetrical federalism'), where different regions had different de-facto and de-jure powers. Such a system was seen as an obstacle for effective governance.

According to the Russian Constitution, the Federation consisted of 89 (83 as of January 2012) de-jure equal regions. The country inherited the system of administrative and territorial division from the former RSFSR. Article 5.1 of the Constitution declares that "the Russian Federation consists of republics, krais [territories], oblasts, cities of federal status, autonomous oblast, autonomous okrugs [areas]. ${ }^{, 10}$ Existence of several categories of regions implicitly suggests that there are differences in legal statuses of these regions. Articles 66.1 and 66.2 of the Constitution clearly demonstrate that. Only republics are allowed to have their own constitutions, whereas all other regions have charters $[u s t a v]$ as their supreme statutes. Complex territorial structures complicated the situation even further. Some autonomous areas were subordinated to other territorial units while preserving their status as units of the federation. The case of Krasnoyarsk krai used to illustrate this situation. Being a federal subject of Russia, Krasnoyarsk krai included two other territories - Taimyr and Evenki Autonomous Areas, which also had the status of subjects of the federation. ${ }^{11}$

In addition, there were different systems of government in the various subjects of the federations. Firstly, the Russian Federation itself, being a presidential republic,

\footnotetext{
${ }^{10}$ Constitution of Russian Federation (1993 issue)

${ }^{11}$ In result of the federative reform this contradiction was resolved and in 2007 Krasnoyarsk krai, Taymyr Dolgano-Nenets Autonomous Okrug and Evenk Autonomous Okrug were united in a single subject - Krasnoyarsk krai. Taymyria and Evenkia were given special statuses within Krasnoyarsk Krai and incorporated as districts.
} 
included regions with parliamentary (Republics of Udmurtia and Dagestan), as well as super-presidential (Moscow) systems. An analysis of regional legislatures would show that some regional constitutions contained contradictions to the Constitution of the Russian Federation. Republican constitutions for instance proclaimed sovereignty over their territories, which conflicted with the norms of the federal constitution, namely that state sovereignty of the Russian Federation over the entirety of its territory is absolute (Article 4.1). Moreover, some constitutions of national republics emphasized special status for title ethnic groups. Such statements conflicted with Article 6.2 of the Federal Constitution that proclaims equality of rights of all citizens of the country over the whole territory.

Some other examples illustrate this quite vocally. The constitution of Tatarstan for instance, proclaimed the republic as a sovereign state and associated itself with Russia only on the basis of a bilateral treaty. During the 1990s, the constitutions of Yakutia, Bashkortostan, and Tyva contained norms that allowed suspension of federal laws within their territories if these laws contradicted that of these republics. Komi, Bashkortostan and Yakutia reserved legal right of a possibility to conduct independent foreign policy and sign international treaties. As Richard Sakwa stresses: "[b]etween 1991-95 alone, Russian regions signed over 300 agreements on trade, economic and humanitarian cooperation with foreign countries, undermining Moscow's monopoly on foreign relations and shifting attention away from high diplomacy to the pressing needs of Russia's regions." ${ }^{12}$ Moreover, the constitutions of Ingushetia, Yakutia, and Tuva nationalized natural resources of their territories.

${ }^{12}$ Sakwa, Richard. (2004). Putin: Russia's choice. New York: Routlege, p. 131. 
This administrative-territorial division of the country was based on the nationalterritorial principle, contained threats for political stability, and gave fertile soil for separatism. The case of Chechnya is the most evident example of such a situation. The restoration of 'constitutional order' in Chechnya in 1994 took the form of open military confrontation between federal forces and rebel unions (who actually presented themselves as well-organized and professionally trained regular military groups) controlled by Dzhokhar Dudayev, then president of the republic. This military confrontation revealed the imperfect character of the established system of federal relations. Indeed the national-territorial principle "in itself implies the basis for separatism."13 Experts argue that "it is condemned to permanent reproduction of negative consequences for multi-ethnic society."14

Bilateral treaties also signified some challenges for efficient governance. Initially, relationships between the federal centre and regions were regulated by a Federative Treaty issued on 31 March 1992 and later approved in the Constitution. The creation of the Treaty was a response to centrifugal tendencies of the first phase of the federative rearrangement. The Treaty delimited exclusive jurisdictions of the federal and regional governments and also regulated principles of common jurisdiction. However, the de-facto legitimacy of the Treaty was undermined by the fact that some regions (and especially some national republics) refused to sign it. From this perspective, the most prominent cases were Tatarstan, Yakutia and Chechnya. The richest regions (such as Tatarstan and Yakutia) obtained tax and budgetary privileges through the bilateral contractual process.

\footnotetext{
${ }^{13}$ Salikov M.S. (1998) “O preimuschestvakh i vozmozhnostiakh sozdaniia territorial'noi federatsii." Polis, No.5, p. 208

${ }^{14}$ Ibid., p. 208
} 
Indeed given this, it was not surprising that both regions signed these agreements quite quickly.

At last, not only the asymmetrical status of the regions in the Russian Federation was understood as a threat of further decentralization but also the quantity of regions itself was seen as problematic by some experts. Analysts criticized the so-called 'hierarchy 1:89' as the principle of arrangement of federative relations within the state. ${ }^{15}$ They point out the fact that too many regions complicate regional policy. Since 1993 and until August 1998 more than 500 intergovernmental agreements were signed in order to regulate regional relations in Russia. Most of these agreements conflicted with federal legislation.

All these factors made the Russian federative system unprecedentedly difficult to manage and potentially unstable. It is very important to notice that some aspects of institutionalization of the system of federative relationships were often the result of bargaining among different political groups. Therefore, by the end of the 1990s, Russia appeared at the edge, particularly in the light of the discourses concerning the future development of the country, which were polarized between the ideas of either: further decentralization and potential disintegration of the country, or turning back to reinstatement of the decisive role of the state.

The federal government understood the destructive nature of contemporary trends in regional politics. In 1994, President Yeltsin issued a decree that established a special committee to control and organize the process of preparing bilateral agreements. ${ }^{16}$

\footnotetext{
${ }^{15}$ Zotova Z.M., Salikov M.S. (1998) “Federativnoe ustroistvo Rossii: dve pozitsii.” Polis. No. 3 pp. 204-210

${ }^{16}$ See: Decree of the President of the Russian Federation No. 1499 from July 20, 1994 "Ob obrazovanii Komissii pri Prezidente Rossiiskoi Federatsii po podgotovke dogovorov o
} 
However this agency's activities did not change the situation. Scholars, analyzing the reasons for its failure, are almost unanimous in blaming the federal government for not having the political will to put an end to centrifugal tendencies. ${ }^{17}$

The economic collapse of August 1998 made the situation even worse. Preserving the status quo in relationships with the regions seemed almost impossible. For the first time in the post-communist history of Russia, as an actual political program, the question of building 'the vertical of power' was raised by then the prime-minister Evgeniy Primakov at the meeting of members of the federal government and regional leaders in the Kremlin on September 29, 1998. On June 24, 1999 President Boris Yeltsin signed famous Federal Statute No. 119-FZ, which became the basis for the 'reconstruction of the state'. This law provided the normative basis for establishing 'the dictatorship of law' - a famous formula later proposed by the President Vladimir Putin. According to this law, all aspects of common jurisdiction henceforth would be regulated by specially issued federal statutes. Moreover, Law No. 119-FZ stated that it was imperative to bring regional legislation into conformity with federal norms and not the other way around.

The political struggle between various elite groups that was initiated in the late Soviet period was one of the major factors that predetermined the hardships of administrative-territorial development of post-Soviet Russia. There was also the important issue of path dependency. The history of Russia's federalism may be traced back to 1918 when the Russian Soviet Federative Socialist Republic emerged as the result of the collapse of the imperial regime. The federative principle of administrative-

razgranichenii predmetov vedeniia i polnomochii mezhdu federalnymi organami gosudarstvennoi vlasti i organami gosudarstvennoi vlasti sub"ektov Rossiiskoi Federatsii" ${ }^{17}$ See for example: Nikolai Petrov (2000). "Federalism po-rossiiski." Pro et Contra. Vol. 5, No. 1., pp.7-33. 
territorial organization was affirmed during the formation of the Union of Soviet Socialist Republics. Indeed the acute political debate on the first Constitution of the USSR ended with adoption of the federative model proposed by Vladimir Lenin and rejection of Joseph Stalin's plan. The latter suggested that all Soviet republics should join Russia as autonomous jurisdictions. If accepted this plan would build the basis for further installment of a unitary system of administrative-territorial organization.

However, the Russian Federation inherited its federative structure from the Russian Soviet Federative Socialist Republic that was established in 1918. Thus, in the situation of political entropy of 1989-1990, the concept of federalism was apprehended as the inherited form of territorial organization and actively used by various political groups as a bargaining tool. Boris Yeltsin and the republican political elites used the system in their struggle with the central government of the Soviet Union; and the regional political elites sought to improve their position vis-à-vis the federative authorities and other regions. Therefore the very existence of the federation and federative relations was predetermined by the history of political development of modern Russia. Most other republics retained their unitary nature of political-administrative organization during and after the Soviet period. Most of them, excluding Georgia, Moldova and Azerbaijan were able to avoid significant separatist conflicts.

One may ask about the reasons why such tensions had not resulted in total collapse of territorial integrity or a movement towards a particular form of confederation. Some scholars predicted such a scenario. ${ }^{18}$ There could be different explanation for why regional elites did not want to break their relationships with Moscow. The most deliberate

\footnotetext{
${ }^{18}$ See for example: Brzezinski, Z. (1997). The Grand Chessboard: American primacy and its geostrategic imperatives. NY: BasicBooks.
} 
ones focus on economic factors. Economic reforms of 1990s ruinously affected most regions. Almost all republics, with the exception of major oil-producing regions, "appeared in the list of losers." ${ }^{19}$ In such circumstances the loss of economic support from the federal government could be fatal for regional, mainly ethnic, elites. In contrast, the establishment of broad autonomy by means of bargaining with politically weak central government seemed as an adequate alternative strategy. Cross-regional infrastructure and economic links must also be taken into consideration in the discussion of the reasons of stability of the federation. Strong regional unions and alliances, such as the association Big Ural, also reinforced cross-regional ties and acted in favor of preserving the supra-regional arrangement of the political space in post-Soviet Russia. Thus, complete disintegration seemed almost impossible and the major question for the reform that began in the new millennium was to improve the effectiveness of government by using traditional mechanisms of central control over the territories.

The middle layer of the pyramid includes reforms which were primarily tasked with changing the ways in which the state operates. The conceptual pyramid approach emphasizes two centres of power. It envisages an idea that the state and the municipal organizations are being tied together and counterbalancing each other. These two centres need an instrument of efficient dialogue between the two. Such dialogue is not possible without a system of efficient bureaucracy. The reform was aimed at building such a system and may be considered as the center of this pyramid. Effective bureaucracy is essential to adjust dialogue between various levels and institutions of executive power. It is seen as an important tool to channel policies issued on the central level. At the same

\footnotetext{
${ }^{19}$ Klimanov, V.V. (2000) Regional'noe razvitie i ekonomicheskaia samostoiatelnost' sub"ectov Rossiiskoi Federatsii. Moscow, p. 38.
} 
time, ideally, bureaucracy must be an effective conductor of demands and aspirations that emerge at the local level. The importance of bureaucracy increases when issues of interbudgetary relations are taken into account.

The fact that Russia is a federative state demands placing regional governments within the conceptual pyramid. The analysis above shows that regional elites were quite an important factor in shaping the geopolitical landscape and influencing the nature of regional politics in post-Soviet Russia. Obviously, for improvement of control over the regions, distinctive policies should be introduced in order to make the regional level of institutions of state act in concordance with that of the federal authorities. However, with respect to the proposed conceptual pyramid, issues related to regional politics and governance are included in the upper layer and discussed alongside other reforms of federative relations. Therefore, discussing issues of government reform, this model (e.g., conceptual pyramid) refers to the regional dimension as the extension of politics at the federal level.

The level of local governments and municipal administration constitutes the bottom of the pyramid. As has been shown, some experts agree that, at least in theory, local self-government must counterbalance the increasing centralization of the bureaucratic apparatus. On the other hand, some suggest that de-facto the reform in Russia ended up embedding local authorities into the all-encompassing system of executive power. ${ }^{20}$ As Gelman suggests, in reality, "a soft revision of the constitutional

${ }^{20}$ Tomila V. Lankina, (2005). "President Putin's local government reforms." In: Reddaway, Peter and Orttung, Robert W., (eds.) The dynamics of Russian politics: Putin's reform of federal-regional relations. Rowman \& Littlefield, Lanham, MD, USA. 
norms took place. ${ }^{21}$ Nevertheless, the reform of local self-government was an important item in the political agenda of Putin's administration. To address this issue the president commissioned his Deputy Chief of Staff Dmitri Kozak who stood at the top of the state commission. Dmitri Kozak was also appointed the head of the State Commission responsible for developing and implementing the reform of public administration. These two facts serve as an empirical justification of the approach to analysis of political reforms within the single conceptual pyramid of governance.

Kozak's commission designed the reform of local self-governance on the basis of rational and technocratic premises. It emphasized separation of administrative and political functions of local authorities. Whereas the former were substantially reduced, the latter, at least on paper, were clarified and enhanced. The program of reform addressed several features of local governments pertaining to the issues of governance. First of all, a new three-tier system of local administrative-territorial division was introduced. It included: city districts, municipal counties and rural settlements. This system reorganised local governmental bodies and delineated their areas of competence and responsibility, which allowed the reduction of duplicate governmental functions by various municipal organizations. Secondly, in order to improve transparency and efficiency, municipal administrations lost control over the provision of some state services, namely education and healthcare. They were transferred to the level of regional governments. However, housing facilities remained under control of the municipal authorities. This decision was purely technocratic. As far as these withdrawn services were being financed by the state and regional governments, they became part of the

${ }^{21}$ Gel'man, Vladimir. (2007). "Ot mestnogo samoupravleniia - k vertikali vlasti." Pro et Contra, No.1 (35). Moscow: Moscow Carnegi Center. p. 10 
power vertical, and thus the state wanted to exert a higher level of control over the distribution of funds. At the same time, trying to avoid excessive centralization and remembering the deficiencies of the over-centralized Soviet system, the reformers left most local issues at the municipal level, providing necessary flexibility for administrators to maneuver.

Representative functions of municipalities and their direct accountability to the public were put aside; at the same time their managerial functions were given primary consideration. The federal law on local self-government FZ-131 assumed that "local selfgovernment fulfills administrative (and not political) functions." ${ }^{22}$ Leaving limited executive functions for exclusive local discretion, the new law also stripped local authorities of fiscal abilities. Thus, at least in principle, the idea of separation of political and administrative functions on the local level fit the technocratic logic of the conceptual pyramid of governance.

Therefore, it is obvious that the role of the state bureaucracy had to increase. Therefore, productive dialogue between the two layers of power is hugely dependent on the competence of state workers. The conceptual pyramid of governance synthesizes a variety of seemingly separate political reforms into a single theoretical framework. It allows to bind them together in order to improve understanding of the underlying rationale of the political project of the Russian political elite that acquired power in the early 2000s.

22 Ibid. 


\section{The 'vertical of power' ideologeme}

The 'conceptual pyramid' approach helps structure the reforms of public institutions into a clear and obvious scheme and distinguish three particular layers of governance that exist in contemporary Russia. Yet, its focus is limited to structural aspects of the system of public institutions. At the same time, the program of reforms, proposed by the new ruling elite in the early 2000s went beyond bringing into proper order the relations between different layers of government. The reforms that reshaped the sphere of public policy, civic relations and even economic processes in Russia in the first decade of $21^{\text {st }}$ century can be consolidated under the aegis the 'vertical of power' (or 'power vertical') ideologeme.

The 'vertical of power' is not solely an academic invention. Instead, it was first formulated in the late 1990 s in political circles as a political metaphor that emphasizes solidity and the top-down principle of subordination of the state apparatus. Only later was this metaphor given scientific connotation and understood as a method of systematization of political reforms in the Russian Federation. As a particular political platform it included a set of measures aimed at enhancement and centralization of the institutions of power in the country. As part of the new national ideology put forth by President Vladimir Putin, it incorporated a new 'social contract' between the state and civil society. In principle this contract affirmed obligation of the president to promote social stability for and security of the Russian people, whereas the latter agreed on disfranchisement of some political and civil freedoms. In reality this concept went beyond political issues and involved social and economic ones. However, with respect to the goal of this analysis, the latter two may be left beyond the scope of this research agenda. As a new vector of 
political relationships in Russia the concept focused on various measures of centralization of political power and enhancement of the top-down vector of political communication.

The reforms gathered under the umbrella of this concept may be split into two imaginary clusters. The first cluster unites reforms aimed at the structural and institutional transformation of political processes in Russia. Building the 'vertical of power' is an all-encompassing formula revived by Vladimir Putin at the beginning of his presidency. It includes various political transformations, most of which, however, are in one way or another related to reshaping federative relations. Here we may include the other rhetorical formula - 'the dictatorship of law'. Although both concepts seemed to be pointing to different issues, they are deeply interconnected. As was observed elsewhere, Vladimir Putin "tamed both oligarchs and regional barons, and began replacing a corrupt administration with 'the dictatorship of law'." 23 The 'dictatorship of law' was interpreted as the only form of dictatorship people must obey. Moreover, the concept implied a hierarchy of laws where the constitution of the country was regarded as the ultimate law and federal laws had superiority over the regional ones.

The second cluster combines measures undertaken by the ruling political elite in order to rearrange the political process in the country in concordance with the ideology of 'sovereign (or guided) democracy'. The term 'sovereign democracy' was introduced into Russian political discourse by Vladislav Surkov in 2005. Prior to this denomination of the essence of public policy in the country, scholars used such terms, as 'guided' or 'managed' democracy. The concept of sovereign democracy refers to several political practices, both institutionalized and informal, that are aimed at bringing in concordance

${ }^{23}$ Daniel Treisman (2002). “Russia renewed?” Foreign Affairs, Vol. 81, Issue 6. p.59. 
the mechanisms of public policy in the country. As one of the former Kremlin's most profound political experts - Gleb Pavlovskiy - mentioned elsewhere: "politics must... restrict public access to playing with the country until civil society elaborates necessary experience of self-limitation," and that "the constitutional power in Russia must not depend on sporadic acts of public will." ${ }^{24}$ This formula stresses two major aspects of control over public politics in Russia: elections and partisan development. Several measures were adopted in order to rearrange electoral aspects of democratic governance in the country, which will be discussed in the following pages. More complicated measures were also undertaken in order to stabilize the party system in Russia and take control over the majority of opposition. As a result of these undertakings, in recent years the executive branch enjoyed compliance from and like-mindedness with the federal legislature. It is also important that such compliance was achieved, particularly at the lower scales, as well such as at the level of regional politics. That would lead to a suggestion that the first and second clusters of reforms go hand in hand and create a new vector of political dynamics in Russia.

At the same time both concepts - 'vertical of power' and 'sovereign democracy' assume that the role of the state bureaucracy would be drastically increased. The state apparatus acts as the major conductor of policies being designed and issued at the top level. Sustainability of the vertically integrated political system seems to be highly dependent on its ability to act efficiently in order to implement the designed policies, as well as to address emerging issues. The exclusive role of the state apparatus allows

\footnotetext{
${ }^{24}$ Gleb Pavlovskiy (July 1, 2009). "Upravliaemaia demokrtatiia, ili prosto - opytnaia?" Russkii Zhurnal. On-line: [URL: http://www.russ.ru/Mirovaya-povestka/Upravlyaemayademokratiya-ili-prosto-opytnaya] (Accessed: May 15, 2011)
} 
recognizing its reform as the third, separate and quite specific cluster of political reforms. Both, politicians and scholars agree that current bureaucracy is the major and most important obstacle to modernisation of the country. They outline its ineffectiveness, sluggishness and pretentiousness. Politicians stress its negative role in the socioeconomic development of the country. This argument was put in the core of ideology of the administrative reform and was included in all key documents. Academics, on the other hand, are more focused on the nature of the internal modus operandi of the state apparatus. Its internal structural and functional aspects and, more importantly, their effects on the vertically integrated governmental system, are in the core of academic interest.

The Russian political landscape changed substantially over the first decade of the

$21^{\text {st }}$ century. Many different political innovations contributed to the change. At the same time reforms in three spheres constituted the basis of the vertical of power approach. These were: the political reform of the federal legislative body and primarily of The Federation Council; reshaping of the geopolitical landscape of Russia by means of introduction of federal districts; and bringing regional legislation in concordance with the federal one. These three founding aspects of the 'power vertical' doctrine are going to be analyzed in the following pages.

\section{a. Reform of The Federation Council}

The implementation assertion of the 'vertical of power' doctrine began with changes in the upper chamber of the Russian parliament - The Council of Federation. 
Initially it was an elective body. ${ }^{25}$ However already in the first term, many representatives of regional executive bodies became members of the Federation Council. Of 175 members of the Council there were: 5 republican presidents, 11 heads of regional governments and 43 active governors. Such a situation became possible due to inconsistency of legislation in 1993. The principle of occupation of seats in the federal legislative body by the heads of regional executive offices and heads of regional parliaments was later legalized in Federal Law No. 192-FZ. This period in the history of the Federation Council was named the "governors-speakers' draft" or the period of "substitution of mandates"26.

This principle of forming the upper chamber was criticized by politicians, scholars, and public figures. Deputies of the State Duma, lower chamber of the Russian parliament, sent an official inquiry to the Constitutional Court shortly after this law was adopted. However, this request was turned down in April 1997. Academics on the other hand, directly stressed the anti-constitutional features of the passed legislation. For example, Alexander Chertkov mentions that "major principles that laid in the core of this [legislation] did not correspond with the representative nature of parliament and the principle of division of powers. ${ }^{, 27} \mathrm{He}$ specifically emphasized the fact that direct involvement of regional leaders of the executive branch of power into the legislative process confronts Article 10 of The Constitution of the Russian Federation, which

\footnotetext{
${ }^{25}$ According to the Decree of the President of Russia No.1626 from October 11, 1993 "O vyborakh v Sovet Federatsii”, for the first, 2-year interim term, the upper chamber consisted from deputies ( 2 from each region) elected by the majoritarian principle. ${ }^{26}$ See for example: Olga Selezneva (2011). “Deiatelnost Soveta Federatsii Federal'nogo Sobraniia Rossiiskoi Federatsii po usovershenstvovaniiu federativnykh otnoshenii”). Moscow, 2011. PhD dissertation.

${ }^{27}$ Chertkov, A. (2001) “O reforme Soveta Federatsii Rossiiskoi Federatsii”. Law and Politics, No.6.
} 
declares that the division of power is the fundamental principle of statehood. Another researcher, Darrell Slider, argues that during Yeltsin's presidency the upper chamber of parliament "was under the control of powerful regional leaders who used the constitutional powers of the FC to veto threats to their dominant position", and moreover, senators "often pursued policies that were designed to obstruct the development of a normally functioning federation., 28

However, Vladimir Putin, who initiated the reform in July 19, 2000, saw a major deficiency of the old system in inconstancy of parliamentary sessions of the Federation Council. Being busy with their day-to-day duties in their own regions, both governors and speakers were able to gather together in Moscow only temporarily. This, according to Putin, was creating a lot of difficulties for effective functioning of the upper chamber. Therefore, he proposed a new law that eliminated direct involvement in the legislation process at the federal level of regional politicians who were occupied with their duties as regional government or parliament leaders. This Federative Law No. 113-FZ from August 8, 2000 "On the rules of formation of The Federation Council of the Federal Assembly of the Russian Federation" stated that each region must be represented in the Federation Council by two appointees (one from executive and one - from legislative bodies).

The President's argumentation seems reasonable if the reform of the Federation Council is seen as an independent and unique event. However, combined with other transformations of federative relations taking place during the first year of Vladimir

\footnotetext{
${ }^{28}$ Darrell Slider (2005). "The regions' Impact on Federal Policy: The Federation Council.", in Peter Reddaway and Robert W. Orttung (eds). The Dynamics of Russian Politics: Putin's Reform of Federal-Regional Relations. Volume 2., Oxford: Rowman \& Littlefield Publishers. p.123
} 
Putin's presidency, this reform must be understood as a crucial step in suppressing regional political independence and enhancement of top-down political processes. However, the political consequences of the removal of governors from the Federation Council may be less visible than the symbolic ones. No longer being able to represent their regions' interests in the Council, governors were still able to influence the legislative process through their personal appointees. Therefore, their exclusion from the upper chamber, in principle, should not influence effectiveness of regional representation at the federal level. Of course, introduction of a mediator - the professional senator created some opportunity for political bargaining between various political forces, both regional and federal.

The role of the institution of regional representatives in the Federal Assembly was given another connotation after the introduction of a new procedure for the appointment of governors. Once governors' offices were incorporated into the unified and centralized system of executive governance, de-facto influence of the federal executive power over the upper chamber significantly increased. In these new circumstances the Federation Council became, on the one hand, the instrument of control of the ruling elite over the legislature, and, on the other hand, - the vehicle of political bargaining between various political forces in the regions. Internal politics within the Federation Council diminished de-facto the influence of regional authorities on the legislation process.

The Law No. 113-FZ did not fully regulate the appointment process. Quite often senators, especially those who were representing governors, were persons with few, if any, real connections in the regions they were selected to represent. Sometimes the appointment of a senator was the result of difficult negotiations between the regional and 
the federal political elites. This led to a situation where some senators united in a powerful intra-parliamental group called 'Federatsiia' (Federation) that was firstly aimed at supporting the legislative initiatives of the executive branch and only secondly at representing their regions' interests. Georgii Kovalev, a political expert, states that as a result of these transformations "governors, who left [the Federation Council], but still hoped to preserve instruments of influence over the senators, were left with nothing.",29 And the Federation Council had become "a dutiful 'voting machine' as well as the State Duma."30

To some extent, elimination of gubernatorial elections in 2004 decreased tensions in federative relations but did not remove them completely. Thus, one of the most prominent regional leaders, president of Tatarstan Mintimer Shaimiev, proposed an idea to represent the regional executive powers with one of the members of current regional government. $^{31}$ This proposal, however, did not come to fruition. The problem of representation of regions however remained topical in the discussions regarding the reforms of the upper chamber. Among the most volatile issues appeared the residency requirement. It was introduced for the first time in 2007 and the requirement was quite significant - ten years. ${ }^{32}$ In 2008 president Dmitry Medvedev, among other amendments to the law, proposed elimination of the residency requirement. The law was adopted in

${ }^{29}$ Georgii Kovalev (2006, June 8). "Sovet Federatsii ne poddaiotsia reformirovaniiu". Politcom.ru. (Online) [URL http://www.politcom.ru/2868.html (accessed September 14, 2011).

30 Ibid.

${ }^{31}$ Alla Barakhova and Olga Kudrina. (2006, June 6). "Vitse-spikery vmesto denezhnyh meshkov". Kommersant No.102 (3433)

${ }^{32}$ Federal Law No. 189-FZ from July 21, 2007 "O vnesenii izmeneniia v statiu 1 federalnogo zakona "O poriadke formirovaniia Soveta Federatsii Federal'nogo Sobraniia Rossiiskoi Federatsii" 
2008 and became effective in January 2011. However, two years later, a new law on the subject matter reinstated the residency requirement but limited it to only five years. Additional restrictions were imposed on the candidates from regional legislatures. It was stated that only those deputies who were elected in regional legislative or municipal bodies could become members of the upper chamber, representing the region where they were elected in..$^{33}$ According to Medvedev, this measure would return political status to the Federation Council as well as improve representation of regions in the parliament.

Thus, one may conclude that starting in 2000 governors' influence on the federal government has been undergoing a continuous reduction. Introduction of The State Council of the Russian Federation - an advisory body to the Head of State that included governors - was an unequal response to the strengthening of the 'vertical of power'.

\section{b. Introduction of federal districts and the institute of presidential envoys}

Almost simultaneously with the reform of the Federation Council that reduced regional pressure on the federal government, the latter went on the offensive and proposed measures aimed at improving control of central agencies over regional ones. One of the most striking was the reinvention of the institution of presidential envoys and the establishment of seven federal districts ('okrugs'). Federal districts were a direct response to the complications of asymmetric federative structure of the Russian state.

Federative districts and the institution of presidential envoys were not innovations that were thought up by Putin's administration. The idea of monitoring regional politics first came into existence in the Fall of 1991. After the adoption of the Constitution in

\footnotetext{
${ }^{33}$ Federal Law No. 21-FZ from February 14, 2007 "O vnesenii izmenenii v otdel'nye zakonodatel'nye akty Rossiiskoi Federatsii v svyazi s izmeneniem poriadka formirovaniia Soveta Federatsii Federal'nogo Sobraniia Rossiiskoi Federatsii"
} 
1993, President Boris Yeltsin re-established this institution. ${ }^{34}$ Presidential envoys were federal public officials employed by the Presidential Administration. However unlike its successor, this institution was almost invisible in the political landscape. As some scholars outline, presidential envoys to the regions had neither political authority nor administrative leverage to face powerful regional leaders. ${ }^{35}$ For example, Cameron Ross argues: "Many of the envoys appointed by Yeltsin had strong ties with their regions, and they soon turned 'native', by representing the interests of those whom they were supposed to be controlling."36

There is another structural characteristic that also determined the ineffectiveness of the institution of presidential envoys in the regions under Yeltsin. There were as many representatives as there were regions in the Russian Federation. Therefore, an additional structure within the President's Administration was needed to monitor and regulate their activity. Being sent into a particular region, the president's representatives had to inform the president on various aspects of the political, social and economic situation in the region. Besides this controlling function they were supposed to fulfil the function of coordinating the work of regional branches of federal institutions of executive power. However, fulfilling this task was very difficult. Due to economic and organisational factors regional leaders were able to control, usually semi-officially, appointments of many key positions to regional branches of various federal organisations (such as the office of state attorney, tax inspectorates, customs officers etc.). In some cases, mostly

\footnotetext{
${ }^{34}$ See Presidential Decree No. 1186 from June 10, 1994.

${ }^{35}$ Irina Busygina. "The President's representatives: problems of establishing and developing an institution." Russian Politics and Law, 1997. Vol. 35(1).

${ }^{36}$ Cameron Ross (2003). "Putin's federal reforms and the consolidation of federalism in Russia: one step forward, two steps back!" Communist and Post-Communist Studies Vol. 36 29-47. p. 33
} 
due to weak economic performance of the country in general, governors had some influence over high-rank military and law-enforcement officials. In such circumstances, presidential envoys could not be perceived as meaningful institutions of power.

Former presidential representatives in the regions and current presidential envoys in the federal districts have different de-jure statuses. Explaining major goals of the president's representatives in the regions is Decree No.53 from February 5, 1993 which stresses the functions of coordination and interaction, particularly between various layers of executive power, both federal and regional, as well as assistance to the president in the implementation of his constitutional powers. In contrast, Decree No. 1149 from June 21, 2000 on presidential envoys in the federal districts, emphasizes the function of the organisation of the political process in the regions assigned to the district. Envoys are no longer mere controllers, or the "president's eyes and ears in the regions." They are active members and organisers of the political process in the regions they are controlling; furthermore they directly answer to the president and are responsible for efficiency of the power vertical. The idea of enhancement of control over regional politics and the affirmation of dominance of the top-down vector of political communication was also supported by Vladimir Putin's careful and deliberate manpower policy. It is quite symbolic that five out of seven initial appointees for the presidential envoys offices had military or law-enforcement background. Selecting such candidates, the president thereby established that among other duties, their major function was the "analysis of efficiency of law-enforcement agencies in the federal district." ${ }^{37}$ Giving the authority of these new

\footnotetext{
${ }^{37}$ See p. 6 of the Decree of the President of Russia No. "O Polnomochnom Predstavitele Prezidenta Rossiiskoi Federatsii v Federal'nom Okruge"
} 
political-geographic units, candidates from the military block (the so called 'siloviki') clearly emphasized the commanding style in regional politics.

It is important to mention here that among quite a few alternative scenarios of delineation of administrative borders of the federal districts, the administration of the president chose one that was based on 'the military-security framework ${ }^{38}$ Thus, it becomes obvious that seven federal districts geographically coincided with the seven military districts ('okrugs'). ${ }^{39}$ This additionally emphasizes the fact that the federal government was seeking administrative instruments to bring the regions into concordance with the policies of the central administration. The administrative dimension of regional politics in Russia was given priority over the economic one. The President preferred overt commanding instruments over more complicated and multilateral mechanisms of interbudgetary negotiations.

There was an alternative project proposed in 1998 by the then prime-minister Evgeniy Primakov. It suggested the establishment of federal districts on the basis of eight interregional economic associations. ${ }^{40}$ These associations were created in order to improve and restore economic links between industrial groups in different regions of Russia that were distorted after the collapse of the Soviet Union. In practice these associations included governors and top officials from regional governments, and thus

\footnotetext{
${ }^{38}$ Nikolai Petrov, (2002). "Seven faces of Putin's Russia: federal districts as the new level of state-territorial composition." Security Dialogue, Vol. 33(1), pp. 73-91.

${ }^{39}$ As of 1998 there were eight military districts (Kaliningrad oblast was singled out in a special district). Each military district in almost all cases included the same regions that were included in the identical federal district. The structure of military districts was reshuffled several times after 1998 (in 2001 and twice in 2010) and the latest arrangement is quite different from the initial one and includes only four military districts.

${ }^{40}$ For more details please see: Nikolai Petrov, Sergei Mikheev \& Leonid Smirniagin, (1993). "Russia's Regional Associations in Decline," Post-Soviet Geography, Vol. 34, No. 1, pp. 59-68.
} 
they "might perform the functions of generating and regulating not only economic, but also the political integration process between the various Russian regions"; and they "could play the mediator's role in the resolution of conflicts between various regions and the federal centre. ${ }^{\not 11}$ Obviously, such self-organised associations exercised significant level of independence from the federal centre. Taking into account the fact that in the early 2000s, Russia was still recovering after the 1998 short-term government bonds default and subsequent financial and economic crisis, and was furthermore unable to provide sufficient economic incentives in order to bring regional policies in concordance with federal goals, and it becomes obvious why the president's team preferred pure administrative tools of controlling the regions. In addition, this decision "in itself was a clear signal to the regional elites about the pattern of future relations between the center and the regions, and about the means of control that Moscow would rely upon." ${ }^{42}$

The establishment of seven federal districts and the associated reduction in the number of presidential envoys reflects the logic of building the vertical of power. If in the 1990s envoys were sent to every region of the federation in order to observe the situation and inform the president, after 2000 seven envoys started to act as supervisors in the assigned regions. The political role and status of presidential envoys was extended after 2004 when the federal centre proposed a new system of appointing regional governors. This measure emerged as a response to the September $1^{\text {st }}$ terrorist attack on a school in Beslan (Republic of Dagestan). The official argument for the abolition of gubernatorial elections stemmed from the inability of elected governors to control and maintain

${ }^{41}$ Nikolai M. Mezhevich, (2005) Osnovnye napravleniia regionalnoi politiki Rossiiskoi Federatsii. SPb. on-line [URL: http://dvo.sut.ru/libr/history/i299mezl/index.htm]

${ }^{42}$ Nikolai Petrov, "Seven faces of Putin's Russia: federal districts as the new level of state-territorial composition." Security Dialogue, Vol. 33(1): 73-91. 2002, p. 74-75. 
security within their regions. However, interpreted through an analysis of the chain of institutional transformations that the federal center had undertaken since 2000, this measure was seen as a logical sequence of the politics of building the 'power vertical'. Furthermore, presidential envoys have begun a playing crucial role in the governors' appointment process. According to the law, it is envoys who, after consultations with the regional legislature and local political elites, propose candidate(s) to the president to choose from. This clearly shows trust to this mediating institution from the Kremlin. The latter sees envoys as their 'eyes and ears' in controlled regions.

The change of the principle of replacement of regional leaders itself signifies the eclipse of the institutional transformation of federative relations and finishes building the vertical of power in the Russian Federation. Some experts, however, outline that after the abolition of gubernatorial elections the institution of president's envoys has become obsolete. ${ }^{43}$ Critics argue that its existence after 2004 shows the inefficiency of the state apparatus and system of governance. They explain that the current state of affairs in the system follows the logic of Pournelle's 'iron law of bureaucracy'. Namely that with lack of public control over its activity, the state apparatus develops, replicates and extends itself. At the same time experts stress only the inspectoral functions of this institution and neglect other administrative functions. Indeed, the institution of presidential envoys as it

\footnotetext{
${ }^{43}$ See for example a comment made by the deputy of the parliament of Kaluga oblast Sergei Fadeev who calls the institute of envoys and inspectors unnecessary and excessive after 2004. IA Regnum (2009, May 4). "Kaluzhskii deputat: "Institut polpredov prezidenta absurden po svoei suti." Regnum. [Online] (URL http://www.regnum.ru/news/1158940.html) (Accessed October 16, 2011). Similar argument is presented by Andrei Kolesnikov who argued that "the practice of gubernatorial appointments has made the institute of president's envoys excessive". Andrei Kolesnikov (2011, September 7). "The end of the institute of envoys." [Online]. (URL http://www.forbes.ru/ekonomika-column/vlast/73169-konets-institutapolpredov\#comments). (Accessed November 26, 2011).
} 
was proposed in the beginning may be seen as obsolete after the abolition of gubernatorial elections. Being incorporated in the power vertical however, governors are supposed to adopt and perform functions similar to those that were performed by the president's envoys in the regions. Governors are thus no longer accountable to their electorate, but to the President himself.

At the same time the argument for the existence of this institution within the governance pyramid may be supported on several accounts. First of all, contemporary presidential envoys are given more political functions than their predecessors. Therefore, they have become capable of exercising control over the regions and keep governors accountable to the federal centre. Secondly, it is also important to mention such functions as coordination of activities of institutions of executive power and pre-emptive resolution of conflicts of interest. For some reason, critics of this institution avoid discussing the fact that in a federative state there are such bureaucratic entities as regional departments of federative institutions of executive power (ministries, inspectorates, etc.). According to paragraph 3(6) of the statute on the president's envoys, they are supposed to provide "coordination of activity of the federal bodies of executive power in a certain federal district." ${ }^{44}$ Coordination is one of the most important functions of any vertically integrated organisation and its importance increases with structural expansion of this organization. Federal districts are determined to play a mediatory and coordinating role between federal and regional executive bodies in such a vast and complex federation as Russia. Performing controlling and regulative functions, presidential envoys are incorporated into the bureaucratic structure of the state and became an important link in

\footnotetext{
${ }^{44}$ Federal Law No. 849, from May 13, 2000 "O polnomochnom predstavitele Prezidenta Rossiiskoi Federatsii v Federal'nom Okruge."
} 
the vertical of power. This argument is partially supported by the fact that an additional, Northern Caucasian federal district was established in 2010, ten years after the introduction of this institution.

In terms of federative relations, the introduction of new principles of filling the position of governors in 2004 was undoubtedly the most indicative administrative measure of building the vertical of power. The procedure of appointment of governors gave the federal centre explicit authority over the political process in the regions. The involvement of envoys in this process gave additional legitimacy to the institution and further enhanced the vertical of power.

\section{c. Bringing regional legislation in concordance with the federal laws}

Construction of the power vertical involved addressing issues that exceed the bounds of administrative relations and expands to the realms of legislative and civic relations. In his article Cameron Ross clearly showed the importance of measures undertaken by the Kremlin in order to reassure equal rights of citizens of the Russian Federation over the entire territory of the country. ${ }^{45}$ The most significant among them was in bringing the regional legislation in concordance with the federal laws and, most importantly, with the Constitution. During the tenure of president Boris Yeltsin federative relations were mainly based on a system of bilateral treaties between the center and the regions. In many circumstances regulations presented in these treaties contradicted to regulations, written in the federal laws. The situation was further complicated by the asymmetrical structure of the federation, especially when republics bolstered more $d e-$ jure and de-facto independence from the federal government.

\footnotetext{
${ }^{45}$ Cameron Ross (2010). "Federalism and inter-governmental relations in Russia." Journal of Communist Studies and Transition Politics. Vol.26, Issue 2.
} 
Such a situation resulted in many conflicts (or in military contestation as in the case of Chechnya) between the federal government and governments of the various regions. Some regions used their status to negotiate better conditions for themselves during the negotiation process of these bilateral treaties. In response, the federal center undertook some steps to control the legislative process in the regions. In 1995 President Boris Yeltsin issued a Decree No. 1007 "On measures for ensuring coordination of federal governmental bodies and regional governmental bodies during the process of conducting constitutional reform in the regions of the Russian Federation." This document stated the priority of the Constitution of Russia and the federal legislation over that of regional ones. Moreover, the president was granted the right to suspend any legal document issued by regional authorities if it contradicted the corresponding federal legislation until the conflicting case was resolved in the court. In addition, the Ministry of Justice was granted the right to conduct expertise of regional laws and governmental documents. ${ }^{46}$ During the 1990 s there were many disputes in the Constitutional court of Russian Federation regarding the controversies and mismatches between federal and regional legislature. Although, "[t]he judgments of the Court issued between 1995 and 1998 largely paved the way for President Putin's campaign of legal unification",47 regional leaders exercised enough political freedom to simply ignore these decisions. Many regions, and especially national republics, refused to provide newly issued legal documents to the Ministry of Justice for expertise analysis. Until 1998, when Evgeniy Primakov became the prime-minister shortly after the financial crisis, there was no

\footnotetext{
${ }^{46}$ See: Resolution of the Government of the Russian Federation No. 550 from June 3, 199. "O dopolnitel'nykh funktsiiakh Ministerstva Iustitsii Rossiiskoi Federatsii."

${ }^{47}$ Jeffrey Kahn, Alexei Trochev, Nikolai Balayan. (2009). "The Unification of Law in the Russian Federation.” Post-Soviet Affairs, 25(4), pp. 310-346.
} 
evidence of any significant achievement in bringing regional legislation in line with the federal one. The situation changed during the Primakov's premiership. As was stated elsewhere, the number of regional legal documents that contradicted to the federal ones had been declining. If in 199730 percent of regional documents that underwent inspection in the Ministry of Justice contradicted the federal laws, then in 1998 the proportion of inappropriate documents decreased to approximately 15 percent. ${ }^{48}$

Such trends became even more evident in the new millennium. Interestingly, even from the beginning of his first presidential tenure Vladimir Putin chose 'hard' rather than 'soft' tactics in constructing his relationships with regional leaders. Using the doctrine of the 'dictatorship of law' that was well received and approved by the population, ${ }^{49}$ Putin proclaimed prevalence of federal legislation over the regional one and urged heads of subjects of the Russian Federation to bring their legislation in line with federal laws.

A set of measures was proposed by the president's team in order to harmonize the legal sphere in Russia. All these measures were designed in accordance with the doctrine of the 'dictatorship of law' as proposed by Vladimir Putin at the very beginning of his presidential tenure. Its major declared goal was creation of a "unified legal space". 50 Indeed it seems that controlling the process of unification of the legislation was the first

\footnotetext{
${ }^{48}$ Ministry of Justice of the Russian Federation. (March 29, 1999). "Pis'mo v Pravistel'stvo Rossiiskoi Federatsii No. 2263-GB".

${ }^{49}$ In 2000 the Public Opinion Foundation of Russia conducted a research monitoring attitudes of the population toward the term "dictatorship of law". According to this research $44 \%$ of respondents positively reacted on this concept and only $6 \%$ disapproved it. Slightly more, $45 \%$ of respondents reflected neutrally on this concept. For more details refer to: Opros Naseleniia (26.07.2000). Testirovanie poniatiia: "Diktatura Zakona". [Online] [URL. http://bd.fom.ru/report/map/az/0-9/24_5913/dd001434] (Accessed December 3, 2011).

${ }^{50}$ Press-conference of the President of the Russian Federation. August 31, 2000. [URL. http://archive.kremlin.ru/appears/2000/08/31/0002_type63380_126555.shtml] (accessed Dec. 16, 2011)
} 
priority for the newly introduced president's representatives in the seven federal districts. Institutional changes took place in many branches of executive power that were involved in this process. Thus, branches of such federal government bodies as the Ministries of Justice and Internal Affairs, the Prosecutor General's Office and some others were established in the federal districts.

In addition to dismissal of regional legal acts, the president of Russia was granted the right to temporarily suspend heads of the regions in case of their criminal prosecution. ${ }^{51}$ Although this regulation has never been used in case of publicly elected governors, this paragraph was still contested by many regional leaders. A special commission on division of areas of competence between federal and regional governments was created in 2001. ${ }^{52}$ This commission inspected around five hundred active treaties signed between the federal centre and the regions and found out that there were contradictions with the federal legislation in almost all of them.

Creation of special governmental institutions spurred the process of unification of legislation in Russia. A myriad of laws and other normative-legal documents were issued after the process was officially announced. These documents covered various spheres of public life. And by the end of the first decade of the $21^{\text {st }}$ century, this process of

\footnotetext{
${ }^{51}$ See: Federal Law No. 184-FZ “Ob obshchikh printsipakh organizatsii zakonodatel'nykh (predstavitel'nykh) i ispolnitelnykh organov gosudarstvennoi vlasti sub' 'ektov Rossiiskoi Federatsii." October 6, 1999. Article 29.1, paragraph 4.

${ }^{52}$ See Decree of the President of the Russian Federation No. 741 of June 21, 2001. "O Komissii pri Prezidente Rossiiskoi Federatsii po podgotovke predlozhenii o razgranichenii predmetov vedeniia i polnomochii mezhdu federal'nymi organami gosudarstvennoi vlasti, organami gosudarstvennoi vlasti sub' 'ektov Rossiiskoi Federatsii i organami mestnogo samoupravleniia."
} 
unification was generally complete. ${ }^{53}$ The corresponding paragraphs that declared sovereign status of the federative republics were excluded from all regional constitutions.

The process of bringing regional legislation in line with the federal laws had a significant impact on one of the most fundamental peculiarities of Russia's state structure of during the 1990s - the problem of asymmetrical federalism. As a result of these unification attempts, all regions in Russia became de-jure equal. However, there remained structural complications in Russian federative relations when some subjects of the Federation were also components of others. The process of merging the regions began after adoption in 2001 of the federal constitutional law No. 6-FKZ "On the procedure of acceptance of a new subject of the Russian Federation." As a result of regional enlargement, the quantity of regions of Russia decreased from 89 to $83 .{ }^{54}$

The idea of regional enlargement partially solved issues of structural complexity of the federative relations in Russia. At the same time, it received diverse estimates by the academicians. Some experts saw positive moments in enlargement of compound regions. Others argued for the uselessness of the process. Critics stressed political and economic inequalities of complex regions. In terms of politics "the [internal] border between a krai and an autonomous okrug signified unequal relations when this krai did not have authority within the okrug's borders, but the okrug was capable to make

${ }^{53}$ See: Aleksandr Rybin. "Konstitutsionnoe sootvetstvie." Rossiiskaia gazeta No.4940 (116). June 26, 2009. p. 2

${ }^{54}$ As of December 2011. In December 2005 a new Perm krai (included Perm oblast and Komi-Perm Autonomus district) was established; in January 2007 an amalgamated Krasnoyarsk krai (included Taymyr and Evenki autonomous okrugs) was established; in June 2007 Kamchatka oblast and Koryak Okrug were united in Kamchatka krai; in January 2008 Ust-Orda Buryat Okrug was included in Irkutsk oblast; and in March 2008 a new Zabaikalskii krai (included Chita oblast and Agin-Buryat okrug) was created. 
decisions on behalf of the krai. ${ }^{, 55}$ At the same time, due to economic infrastructure inherited from the Soviet Union, krais (senior regions) exercised more economic freedom over their satellite autonomous regions. The federal center was positive about the enlargement of regions because this process should actually improve the ability to conduct socio-economic policy and promote successful implementation of the federal programs - a major instrument of macro-economic policy during the presidency of Vladimir Putin. Economic efficiency was made a core of the enlargement. ${ }^{56}$

However, positive appraisals of the enlargement process were not consonant. The Institute of Modern Development - a prominent think tank, often affiliated with the third president of Russia, Dmitry Medvedev - issued a report in which the process of regional enlargement received detailed and well-based critique. They argued that "the campaign... had to show the power of the Centre, but demonstrated its weak competence and insufficient professionalism." ${ }^{57}$ Moreover, they warn that continuation of the politics of enlargement may generate a series of versatile conflicts: from ecological to ethnic. ${ }^{58}$ Authors of this report criticized all goals and mechanisms used by the federal center in its program for enlargement. They argue that socio-economic backwardness of the autonomous okrugs is different in nature and that the "different strategies that take into account the differences of economic situation between the okrugs are needed.

\footnotetext{
${ }^{55}$ J. Paul Goode. (2005) "Rossiia pri Putine: ukrupnenie regionov." Logos 1(46). p. 178 ${ }^{56}$ Ibid. p. 205

${ }^{57}$ Artobolevskiy, C., Gontmacher E. (eds.) (2010). Ob"'edinenie subjektov Rossiiskoi Federatsii: za i protiv. Moscow. p. 174

${ }_{58}^{58}$ Ibid.

${ }^{59}$ Ibid. p. 39
} 


\section{d. The concept of 'sovereign democracy'}

Apart from addressing complexities of the institutional structure of the Russian state, the doctrine of the 'vertical of power' has had an influence on the relations between the institutions of the state and those of civil society. Transformations of governmental institutions at the federal and regional levels went hand in hand with rearranging public politics in the country. Efforts made by the government in order to guide (or as some critics say control) the civil society in Russia were later named 'managed democracy', or as it was stated by officials themselves as 'sovereign democracy'. The term 'managed democracy' with respect to Russia was used by some western scholars when they tried to explain a highly orchestrated electoral process in Russia in the early $2000 \mathrm{~s} .{ }^{60}$ They define a 'managed democracy' as a peculiar type of political regime "where elections are held, but the results are known in advance; courts hear cases, but give decisions that coincide with the interests of the authorities; the press is plural, yet with few exceptions dependent on the government. This is, in effect, a system of 'uncontested power', increasingly similar to the Soviet state, but without any ideological foundation, which is evolving through a set of stages that parallel those of Russian Communism."61 Accusations that the Kremlin's policies endangered democracy in the country were raised not only by scholars but by politicians as well. As Stephen White states, "the changes that were taking place in the law itself were a part of a wider environment in which the scope for autonomous

\footnotetext{
${ }^{60}$ See for example: Lipman, M. and McFaul, M (2001) "Managed Democracy in Russia". The Harvard International Journal of Press/Politics 6(3): 116-127; Colton, T.J. and McFaul, M. (2003). Popular choice and managed democracy: the Russian elections of 1999 and 2000. Brookings Inst. Press.

${ }^{61}$ Perry Anderson (2007). "Russia's Managed Democracy." London Review of Books. Vol.29 No.2. pp.3-12
} 
political action was being progressively diminished." ${ }^{62}$ The Bush administration of the United States was among the most prominent critics of Russia's political regime. In response to this criticism Vladimir Putin, then president of Russia, stated that "the basic principles of democracy, institutions of democracy must be adapted to the realities of contemporary Russian life, our traditions and history.. ${ }^{, 63} \mathrm{He}$ also stated that Russia rejects any political question on the subject matter from its western partners. These words may be considered as a starting point for building the political philosophy of the new regime.

This political philosophy is based on a sort of unwritten social contract between the people of Russia on the one side and the state elite on the other. Social background for this contract was built by quite unsuccessful economic reforms of the early 1990s that included rapid liberalization and deregulation of the economy as well as privatization of state owned property. The result of these reforms was significant pauperization of the population and the creation of an extremely wealthy but numerically tiny class of business elites that were called 'oligarchs' by the public. The essence of the new contract proposed by Vladimir Putin was outlined in his program article "Russia on the edge of millennia." ${ }^{\prime 64}$ Broadly speaking, the contract stated that the society agrees on some reduction of its political rights in exchange for establishing of an order, political stability

${ }^{62}$ Stephen White (2001). "Elections Russian-Style". Europe-Asia Studies, Vol.63(4), p.533

${ }^{63}$ Vladimir Putin. (2005). Interv'iu "Radio Slovensko" i slovatskoi telekompanii STV, February 22, 2005. [URL] http://archive.kremlin.ru/appears/2005/02/22/2118 type63379 84394.shtml

${ }^{64}$ Putin, Vladimir. "Rossiia na rubezhe tysiacheletii," Nezavisimaya gazeta, No.245 (2061), December 30, 1999. 
and sustainable economic growth. By many accounts, this was an adequate reaction of political elites to the public demands of the late 1990s. ${ }^{65}$

For the purposes of this research, the versatile actions to rebuild social relations in compliance with the concept of sovereign democracy, which were undertaken by the political elites under Vladimir Putin's leadership, can be narrowed down to three major blocks. The first one is related to the transformation of the electoral process in order to build a reliable and predictable legislative branch. The second block relates to the transformation of partisan politics and regulations of non-governmental organisations. The third block deals with attempts to control mass media in order to control public opinion and build a plausible image of a contemporary ruling elite. These blocks directly relate to the idea of building the vertical of power as far as major spheres of nongovernmental relations have been put under directive political control. Analysis of these three aspects of public politics is also important because the relationships between state bureaucracy and civil society are at the core of the working hypothesis of this research. The entire design of the reform of public administration and civil service was aimed at improving the quality of provided public goods.

The doctrine of 'sovereign democracy' has become the major ideology of the ruling political elite in Russia. On the one hand, it stems from the logical necessity to expand the vertical of power beyond the borders of the state apparatus and include different political institutions and relations. On the other hand, it reflects the necessity to justify the new form of social relations from public request for a new ideology as well as

\footnotetext{
${ }^{65}$ Dmitrii Orlov (2009). "Narushiteli Konventsii: Ob obshchestvennom dogovore podlinnom i mnimom.” Nezavisimaya Gazeta. March 27. No.61
} 
to explain and defend the new form of relations from the critics who accused the current political elite of authoritarianism.

'Sovereign democracy' is very much a philosophical concept and it addresses both aspects of democratic theory as well as ideas of national identity and sovereignty. In the way it was formulated by Kremlin officials, the concept "represents a comprehensive multi-tier political and ideological project that calls for an equally multi-tier interpretation. ${ }^{, 66}$ From this official definition, as given by Vladislav Surkov (who is considered to be the author of this concept within the Russian context), it is hard to understand the key ideas that constitute the basis of critique of the concept by scholars and politicians. However the definition implicitly justifies the words of Vladimir Putin, particularly that Russia needs to adopt democracy to Russian reality. It stresses the exclusive role of the Russian nation in "electing, forming and guiding the institutions of power in the Russian territory. ${ }^{, 67}$ In the key article written by Surkov, there are some tacit references to the current political regime in Russia built by Vladimir Putin. The article stresses Russia's sovereignty, and argues against manipulations by the state that took place in some post-soviet republics whose domestic political elites were not able to put to good use the freedoms acquired with the collapse of the Soviet Union and protect their national sovereignty. Such events as the 'coloured revolutions' are not directly mentioned in the article, however the author believes that they are examples of intervention and deterioration of national independence. ${ }^{68}$ Russia's internal critics are

\footnotetext{
${ }^{66}$ Andrei Okara (2007). Sovereign Democracy: A New Russian Idea or a PR Project? Russia in Global Affairs. No.2, July - September. p.

${ }^{67}$ Vladislav Surkov (2003). "Natsionalizatsia budushchego: paragrafy pro suverennuiu demokratiiu." Expert, 43(537).

68 Ibid.
} 
also blamed for the inadequacy of their views to the political reforms in Russia in the early 2000s. Vladislav Surkov states that such critics "dash aside even from the shadow of regulation and procedure." ${ }^{.69}$

Although there were many different interpretations of the term that stem from the period of Taiwanese liberation from communist China, in the Russian case "[t]he current situation, as interpreted by Surkov, necessitates an accent on the problem of sovereignty and Russia's international substantial, thus proving that the existing top list of threats and challenges differs from the one of the beginning of the decade." ${ }^{, 70}$. What makes the concept of 'sovereign democracy' peculiar, particularly when compared with other political and philosophic interpretations of democracy, is the role of the state. According to its postulates, the state must exert control over the strategic sectors of the national economy and the social sphere, such as natural resources and central media. This political system was later interpreted as the "state-corporation" by Karen Markaryan. ${ }^{71}$ Such a corporatist perception of Russia, with its emphasis on a strong state provides the ideological underpinning for the Russian political system with "an effective monopoly on power by the Kremlin." ${ }^{72}$ In this interpretation, 'sovereign democracy' also reiterates the earlier connotations of the 'managed democracy' concept.

There were some policy steps behind this political-philosophical façade. In order for the state to be governed as a corporation, all its mechanisms needed to be put to work

\footnotetext{
69 Ibid.

${ }^{70}$ Andrei Okara. (2007). "Sovereign Democracy: A New Russian Idea or a PR Project?" Russia in Global Affairs. No.2, July - September. p.

${ }^{71}$ Karen Markarian (2006). "Strategiia: Rossiia kak gosudarstvo-korporatsiia," Politicheskii klass, January, 1.

72 Mark Smith (2006). "Sovereign Democracy: the Ideology of Edinaia Rossiia." Conflict Studies Research Centre. 6(37)
} 
harmoniously, including those beside the vertically integrated state apparatus. Perhaps most crucially for the successful implication of the concept was acquiring control over the legislative body, which was not possible to restrain by means of administrative mechanisms. In the years preceding Putin's first tenure, the ruling political elite did not have strong political support from the federal legislative body - the State Duma. Vladimir Putin however took office in 2000 not only with the rising support of the people, but he also received significant backing in the Russian parliament as well.

The Federal Law No. 51-FZ, which was adopted in 2005, drastically changed the principles of parliamentary elections in the country. First of all, the mixed majoritarianproportional system was changed to a purely proportional one. The consequences of this transformation are yet to be explored in great detail. Although there have been two election campaigns in Russia under the new legislation, not enough academic analysis has been produced on the subject matter. Secondly, in order to stabilize the party system and make the Duma more manageable, the law introduced a seven percent threshold substituting the previously existed five percent one. Indeed only those parties that gained at least seven percent of the popular vote are allowed to enter the Duma. Thirdly, the law reduced to 25 percent the election participation threshold. Since 2005 elections are considered successful if only a quarter of eligible voters casted their votes. Earlier editions of the law on the elections of deputies of the State Duma demanded that minimum of 50 percent of voters take part in the elections. Fourthly, the terms of office of both the President and the State Duma were increased from four to six and five years respectively. Finally, in July 2006 an option to vote against any candidate or party was taken off from the ballot. 
However, there were no obvious reasons for lowering the minimum threshold for turn-out as well as excluding the 'against all' ballot option. There were only two elections to the Duma in which turn-out was lower than 60 percent (in 1993 and 2003). The same is correct for the presidential elections: the turn-out has not yet been lower than 64 percent. Lowering the turn-out threshold was reasonable in case of regional elections that are not as popular as federal elections. The 'against all' option also had never been a critical factor for the elections. The percentage of such votes was relatively low as well as constant (2-5 percent in case of parliamentary elections and 1,5-3,5 percent in case of presidential elections). At the same time however, there were indications of the increasing popularity of this 'option' among voters. ${ }^{73}$ Regardless of this fact, it was still but a minor obstacle, and officials decided to follow the practice of the majority of Western democracies where such an option is not provided.

All these steps were perceived by the opposition as attempts to reinforce authoritarianism in Russia. However regardless of any ideological accusations, these measures definitely were steps towards improving the manageability of the electoral system in Russia. Since its establishment in December 2001 the pro-presidential United Russia party has been able to win a majority in all elections it participated. In the fifth Russian parliament (2007-2011) the party enjoyed an almost absolute majority winning 315 seats out 450 seats, and making the Duma "a dutiful tool that stamps laws." "74 Although the current sixth parliament has lower representation of the "party of power"

\footnotetext{
${ }^{73}$ Stephen White, Olga Kryshtanovskaya (2011). "Changing the Russian Electoral System: Inside the Black Box." Europe-Asia Studies, Vol. 63:4, p.566.

${ }^{74}$ See: "Vladimir Putin: Rossii ne nuzhna poslushnaia Duma, shtampuyushchaia resheniia." (2011, October 28) RosBusinessConsulting. (Online) [URL: http://top.rbc.ru/politics/28/10/2011/622704.shtml] (Accessed January 15, 2012)
} 
(238 seats) the United Russia still enjoys a simple majority in the Duma. Many experts expressed concerns about recent elections being open and democratic. As Stephen White argues: "[t]he heavily Kremlin-dominated nature of the electoral mechanism... led to a more sceptical view of the entire exercise... that these were not elections as they were understood in (for instance) Western democracies." ${ }^{, 75}$

The move from a mixed to proportional representation electoral system, as Kryshtanovskaya and White argued, was done mainly to "eliminate the 'unpredictability' that had always been inherent in the single-member constituency elections." ${ }^{.76}$ This unpredictability was merely based on open competition in the electoral district and emphasized the role of individuals (candidates). The mixed system was also conducive to the enhancement of regionalism in the country: deputies elected in majoritarian districts were mostly incentivized to promote and support their own regions in the State Duma. Indeed on some occasions they were closer to (or more dependent on) regional leaders rather than on their own party leaders. Therefore attempts to abandon the majoritarian districts went alongside with the federal policy of restraining regional liberties and solidifying the vertical of power.

Another less institutionalized but heavily criticized feature of the electoral system, the so called 'administrative resource' was widely utilized. The term is defined as a "combination of means at the disposal of the [top public officials]... to influence the

\footnotetext{
${ }^{75}$ Stephen White (2011) “Elections Russian-Style.” Europe-Asia Studies, Vol. 63:4, p.536

${ }^{76}$ Stephen White and Olga Kryshtanovskaya (2011). "Changing the Russian Electoral System: Inside the Black Box." Europe-Asia Studies, Vol. 63:4, p.562.
} 
opinion and behaviour of electors. ${ }^{, 77}$ Electoral fraud, although widely discussed in the media, is difficult to properly document. Despite the plethora of accusations in the media regarding the use of the administrative resource during and after almost every election campaign, whether federal, regional or municipal, the quantity of academic analysis on the subject matter is still scarce. However, the existing literature allows to pool various techniques into two large clusters - namely institutional and processual. Furthermore, all techniques may the grouped according to their compliance with the law on legal (or barely legal) basis. The completely unlawful ones, although being closely related to the main goal of electoral manipulation, would be the topic of another research project on electoral fraud. This dissertation, however, is focused on the mechanisms of installment of the 'vertical of power' as a new legitimate principle of governance in Russia. Therefore, illegal electoral practices are not investigated here, regardless of their utilization in the political process.

The improvement of control of the electoral process by executive authorities is the primary purpose of the institutional cluster of 'administrative resource' measures. This objective is achieved by means of a creation of additional leverage to enhance control over elections. First of all, the law on elections allowed political parties to use prominent political figures as heads of their federal and regional party lists. Practically however, regional governors stay at the top of regional party lists. Needless to say that since 2004 the overwhelming majority of governors have been members of the pro-Kremlin United Russia party. Both recent presidents Vladimir Putin and Dmitry Medvedev stood at the head of the United Russia federal party list in the recent parliamentary elections. This

\footnotetext{
${ }^{77}$ Vorontsova, A. V., Zvonovsky, V. B. (2003) "Administrativnyi resurs kak fenomen rossiiskogo izbiratel'nogo protsessa", Polis, 6, p. 114
} 
principle of using 'political heavyweights' in order to boost a party's own popularity does not necessarily show the bias and unfairness of the electoral process in countries with proportional electoral systems. At the same time, it is expected that such persons who head party lists would join the parliament for the term they were elected, or would at least be actual members of the party. In Russia however, both Putin and Medvedev, despite their deep affiliation with the United Russia party, were not its registered members during those election periods while they were heading the party lists. Since 2008, Vladimir Putin holds the unusual status of 'party leader' without actually being a party member.

More importantly, after an election, these 'top faces' of the party are allowed to pass their deputy mandates to people who stand lower in the party list. Stephen White counted that after the 2007 Duma elections, as a result of this practice, United Russia transferred more than a third of its mandates to lower level members. ${ }^{78}$ Governors and other well-known political executives stepped down passing their mandates to career parliamentarians. This situation creates a potential for amalgamation between the executive and legislative branches of the state, which is contradictory to the ideology of presidential republics. Another measure that is worth mentioning here is the increase of membership (up to 50\%) of public officials in the electoral committees of different levels.

The cluster of procedural instruments of controlling an election is focused on the forms of use of administrative power by designated executives. The signature-gathering process has become the major vehicle for exclusion of unwanted parties and candidates from participation in campaigns. Introduced institutional restrictions created a very effective system of leverage for the executives. These restrictions are: 1) the quantity of

\footnotetext{
${ }^{78}$ Stephen White (2011). "Elections Russian-Style.” Europe-Asia Studies, Vol. 63:4, p.536
} 
signatures submitted for authentication cannot exceed the pre-set minimum by more than $5 \%$ for federal elections, and $10 \%$ at regional or municipal elections (previously $25 \%$ ); 2) furthermore, the quantity of inauthentic or invalid signatures within those verified must also not exceed the 5\% level for federal elections and $10 \%$ for regional and municipal ones (previously also 25\%). As one expert notes "the given requirements are such that almost any contender, who collected the necessary signatures, may still be refused registration., ${ }^{, 79}$

The second most efficient measure to control the election process is the procedure of dismissal of observers from opposition parties or candidates at polling stations. Although there are no official statistics for such cases, in 2011 State Duma elections an independent non-governmental organization "Golos" reported around 700 such infringements. Indeed in 165 cases an official appeal was filed. For 2012 presidential election the statistic is 953 cases of infringement of which 228 were officially appealed. Dismissal of observers creates potential for further electoral fraud or manipulation during voting and the process of calculation of results.

Candidates may also be dismissed during the campaign for violating the norms of such laws as "On resistance to the extremist activity..."or "On intellectual property", which can be interpreted quite broadly. During election campaigns candidates cannot use visualisations of their opponents without their written consent. Moreover, article 56 of the law "On the basic safeguards of electoral rights of citizens of the Russian Federation" in principle prohibits open public criticism of opponents during the campaign.

${ }^{79}$ Andrey Buzin (2007) Administrativnye izbiratel'nye tekhnologii i bor'ba s nimi”. p.38 
As a result, a complex of electoral reforms has brought some sort of order, accuracy and controllability in the election process in the country. The idea of order was promoted by Vladislav Surkov in his statements on 'sovereign democracy'. Furthermore, the simplification of the organisational structure of the Russian parliament by means of imposing additional barriers and restrictions served this goal unequivocally. One may observe the stabilization of partisan arrangements in the Duma in the last two electoral cycles. Since 2007, the same four parties have been presented in the Duma, mostly due to the reform of the electoral legislation when the creation of electoral blocs and associations was abandoned. In previous electoral cycles, smaller and less popular parties were able to unite in electoral blocks, some of which succeeded in passing the 5 percent threshold. In the 2003 Duma elections, the bloc 'Rodina' received more than 9 percent of the public vote; in 1999 elections the quite influential 'Motherland-All-Russia bloc' came in third.

The electoral reform is certainly conducted in accordance with the ideology of a sovereign democracy. First of all, the change of the electoral system solidified the parliament and, together with the increased threshold levels, improved its predictability and manageability. A proportional electoral system also contributes to strengthening the 'power vertical'. The system of party lists and possibility of passing deputy mandates creates a situation when the parliamentarians from the pro-government party answer directly to their superiors; and the latter are accountable to top officials of the state who also control the party itself. Voters on the other hand, have to vote for the party and its ideology and not a particular deputy. Therefore, members of a particular municipal community cannot address their issues to a deputy who is accountable directly to them, as 
it happens in the states with majoritarian electoral systems. From this point of view, the electoral reform can indeed be understood as an enhancement of the power vertical.

Some important transformations were also made in the sphere of partisan politics. There were some attempts to build a political party in the 1990s that would represent the goals and values of the ruling political elite. Yet these parties were rather unsuccessful in elections. In the 1993 Duma elections, the pro-president 'Russia's choice' party, led by then vice prime-minister of Russia Yegor Gaidar, gained only 15.5\% of popular votes. During the subsequent elections, held in 1995, another pro-government political party 'Our Home - Russia' received just over $10 \%$ of votes. The situation slightly changed in the 1999 elections when the pro-Putin political movement Unity received $23 \%$ of votes. This was only one percent less than the Communist Party - which was one of the major political actors during the first decade of Russia's independence. ${ }^{80}$

The need for significant representation of the contemporary ruling elite in the legislative body was obvious for performing significant political changes in the country. At the same time, the field of partisan politics during the 1990s was quite versatile. There were thirteen parties that participated in the 1993 elections. The number of participants increased to forty three in 1995, when the first non-transitional parliament was elected. During the 2000s, after the new law 'On political parties' was adopted, the amount of parties, unions and blocks has gradually started to shrink. ${ }^{81}$

\footnotetext{
${ }^{80}$ Yet they were less successful in majoritarian electoral districts receiving only 9 seats in the parliament, whereas CPRF won in 46 districts.

8126 parties and block took place in the 1999 elections, 23 - in 2003 elections, 11 - in 2007 elections and, finally, only 7 parties were allowed to participate in the most recent, 2011 Duma elections.
} 
Indeed the process was heavily regulated by the law 'On political parties' that was proposed by Vladimir Putin in the early years of his first tenure as president and passed by the Duma in 2001. This law put some restrictions on the process of registration of a political party. One of the crucial requirements - the quantity of active members - has been constantly changing. The law initially proposed a number of 10.000 members; the quantity was later changed to 50.000 members in 2004 . Since 2010 the required number of members was reduced to 45.000 with an additional 5.000 members reduction beginning in January 2012. As a result of the mass protests that began shortly after the State Duma elections on December 4, 2011, the latest edition of the law (dated April 4, 2012) included a radical decrease of membership requirement to 500 members. This requirement shows a direct correlation with the quantity of political parties in the country, however it is not the sole or dominant factor. If in 1999 there were 139 parties in Russia, then, by 2003 there remained only 48. After the new edition of the law was issued, there were only 14 parties officially registered by the Russian Ministry of Justice. As of January 2012 there were only 7 officially registered political parties in the country. And after the adoption of the latest edition of the law the quantity rapidly increased to several dozen.

This correlation is also addressed in academic debates regarding the significance of this factor for building a stable and continuous party system in the country. For example, Arkadii Liubarev, head of the Independent Institute for Elections, argued that the increase of minimal number of party members would make impossible the creation of genuine, grass-roots parties because "it is very difficult to gather so many supporters, 
especially in the regions, at the early stages. ${ }^{.82}$ At the same time Kenneth Wilson calls this concern "the least convincing", and argues that if a party were unable to recruit a membership of 10,000 from a population of some 146 million there would simply be no point in its competing in a national election." ${ }^{83}$ Obvious changes in the sphere of party politics were aimed at building such a system "in which there were no more than, say, four parliamentary parties, or just two or three, of which one would be expected to win at least two-thirds of the seats, which would make the Duma entirely subordinate to the Kremlin." 84

To some extent, the need for the reform of the party system was ascertained by the necessity to solidify the sphere of public policy. Society with a highly fragmented partisan arrangement was considered by the Kremlin to be liable to political instability. Examples of Georgia's 'Rose revolution' and, more importantly, Ukraine's 'Orange revolution' lend weight to such a threat. ${ }^{85}$

Discussing the contemporary spectrum of Russia's public politics, Vladimir Gel'man suggests avoiding traditional classifications and argues that "no political party in today's Russia is fully independent of the presidential administration. ${ }^{״ 86} \mathrm{He}$ argues that there are three layers or 'circles' of loyalty. The United Russia - the 'party of power' occupies the first layer. There are some parties who are considered somewhat loyal to the Kremlin - A Just Russia party (leader - Sergey Mironov) and Zhirinovskiy's Liberal-

${ }^{82}$ Olga Pavlikova, (2008, October 31) "Bol'she chlenov - men'she partii." Gazeta.

${ }^{83}$ Kenneth Wilson (2006) "Party-System Development Under Putin." Post-Soviet Affairs, No. 22:4, p. 317.

${ }^{84}$ Stephen White, Olga Kryshtanovskaya (2011) "Changing the Russian Electoral System: Inside the Black Box.” Europe-Asia Studies, Vol. 63:4, p.562.

${ }^{85}$ Vladimir Gel'man (2008). "Party Politics in Russia: From Competition to Hierarchy." Europe-Asia Studies. Vol. 60, No. 6, pp. 913 - 930

${ }^{86}$ Ibid., p.920 
Democratic party - which form the second layer. In the third layer there are such parties that are perceived as the opposition to the Kremlin regime. These are the Communist Party (CPRF), Yabloko, and 'The Right Cause' (previously the Union of Right Forces). Although Gel'man's article was written on the eve of the crisis that escalated tensions in Russian politics, ${ }^{87}$ the proposed taxonomy seems correct even through contemporary analysis.

The idea of making political parties more or less dependent on the presidential administration by means of legal and institutional regulations, reflects the same logic of patronage subordination that was successfully used in dealing with the regions. ${ }^{88}$ In case of political parties, the presidential administration was able to reunite the elite, which was divided during the 1999-2000 period of transfer of power. Almost two years after the 1999 elections the Unity Party, the Motherland party and the All Russia party, formed a new amalgamated party, instantly gaining the decisive majority in parliament and thus, marginalizing other political forces. Securing the majority in the Duma, the party-ofpower was able to create the semblance of political debate by creating a right and left wing within itself; or as they are called "discussion clubs" by the party members. An idea for such separation was to build the basis for constructive discussion. However, the idea might be even more far-reaching - by further diminishing the significance of the third layer of opposition parties on both sides of the political spectrum.

${ }^{87}$ After the October 2009 regional elections that resulted in success of the United Russia party and followed allegations of unfairness of the entire campaign, three opposition factions in the State Duma abandoned the regular session and demanded from the President to respond on this situation. This was the first public demarche of the opposition since Vladimir Putin's first tenure.

${ }^{88}$ See: Joan DeBardeleben and Mikhail Zherebtsov (2010) "The Transition to Managerial Patronage in Russia's Regions", in Vladimir Gel'man and Cameron Ross (eds.) The Politics of Sub-National Authoritarianism in Russia. London: Ashgate pp. 85-106 
Apart from broadening the ideological framework of United Russia, the presidential administration might have an even more ambitious goal - to build a system with two dominant but yet controlled parties. The one would obviously be the United Russia party, and the other, A Just Russia party, created in 2006. Interestingly enough, the A Just Russia party was established simultaneously with the final formulation of the concept of 'sovereign democracy'. The party was also built from the top, and united parties of social-democratic and national-patriotic ideology, building a strong socialdemocratic political vector. The party was designed to compete with the communists (CPRF) on the left under control of the presidential administration. This would allow the main party in power to move more towards a conservative ideology. Thus ideally, both parties would cover the centre of the political spectrum, leaving some space for nationalist ideology of Zhirinovskiy's party and having two alternative parties - the communists and the liberals on the margins.

Should it be successful, one may assert that the idea of managed/sovereign democracy fully complemented vertically integrated executive power. However, it is assumed that instead of competing with the Communist Party, A Just Russia party started to compete with the United Russia party at the regional elections. United Russia was the object of criticism for candidates of A Just Russia at recent regional and federal elections. Such a position was criticised and named "fallacious" by the leaders of United Russia. ${ }^{89}$ In some instances (like in elections to the Stavropol krai legislative assembly in 2007) A Just Russia was able to outstrip the United Russia party. Moreover, mass protest actions

\footnotetext{
${ }^{89}$ See for example: 'Edinorossy posovetovali Mironovu borot'sia za oppozitsionnyi elektorat". May 24, 2011. Polit.RU|Online| (URL:

http://www.polit.ru/news/2011/05/24/ai/) (Accessed: January 22, 2012)
} 
during the winter of 2011-2012 showed the ineffectiveness of control over the party system as it was unable to achieve this control without alleged electoral manipulation and fraud. The public was furthermore not convinced in the victory of the United Russia party and assumed that the elections were "orchestrated".

Regardless of recent drawbacks it is still accurate to assume that through electoral and party system reforms, the president gained control over the legislative process in the State Duma, making it act in collaboration with the government and the presidential administration. As Thomas Remington's research has revealed, the Duma has become an obedient and pretty effective tool in hands of executive power. ${ }^{90}$ The obedience of the upper chamber, as it was mentioned earlier in the chapter, was achieved by reforming the Federation Council in particular and federal relations in general. Thus, it may be concluded that by the end of his first presidential tenure Vladimir Putin was able to put the legislative branch under control of his administration.

But electoral and party system reforms were only one part of controlling the political processes within society. Through visible control and censorship of major media sources, as well as increasing limitations on the freedom of civil action, the state extended its influence to other spheres of public policy. The 1996 presidential election demonstrated the importance of mass media. Several months before this presidential election, Boris Yeltsin's (then, active president) popularity was as low as five percent according to the public opinion polls. ${ }^{91}$ Yet he was able to win in the second round. The

\footnotetext{
${ }^{90}$ Thomas Remington (2008). "Patronage and the Party of Power: President-Parliament Relations Under Vladimir Putin.” Europe-Asia Studies Vol. 60, No. 6, pp. 959 - 987

${ }^{91}$ See for more details: S. Migdisova et. all. (1995) "Lebed', Iavlinskii i Chernomyrdin osnovnye pretendenty na post prezidenta Rossii." FOM-Info, 48. [URL:
} 
situation was repeated in 1999 when in August Vladimir Putin was appointed as Prime Minister of the Russian government. It is worth mentioning that before this point he was barely known by the public. A public opinion poll conducted shortly after Putin's appointment as prime-minister showed that approximately 74 percent of respondents had not known or heard about him. ${ }^{92}$ The same poll showed that only 10 percent of respondents believed he could win the presidency and 61 percent were sure it was very unlikely to happen. Yet, Vladimir Putin won the March 2000 elections in the first round with almost 53 percent of votes. Between August 1999 and March 2000 there was a very vigorous information campaign that involved aggressive propaganda for Vladimir Putin and his Unity party and against two largest opponents: primarily Evgenii Primakov and Yuri Luzhkov, and their Motherland party as well as the already 'traditional' opponent, Gennadii Zyuganov and the Communist party. ${ }^{93}$

The role of the mass-media in the political process in Russia cannot be underestimated. $^{94}$ It was obvious for the presidential crew as well. Therefore, organizations allied with the Kremlin undertook strategies to purchase media companies, starting with Channel One (previously known as ORT) from Boris Berezovskiy in 20002003. In 2001 Gazprom, a state monopoly, gained control over NTV Broadcasting company, which was previously owned by the media magnate and banker Vladimir

http://bd.fom.ru/report/map/finfo/finfo1995/of1995_48/of19954803] (accessed Dec. 26, 2011).

${ }^{92}$ Anna Petrova et all. (1999). "Vladimir Putin v otsenkakh rossiian." FOM-Info, 34. [URL: http://bd.fom.ru/report/map/finfo/finfo1999/546 11191/of19993402] (accessed Dec. 27, 2011)

${ }^{93}$ For more details on the subject please refer to: Sarah Oates (2011). "The Media in Russia." The Slavonic and East European Review. Vol. 89 No.2 pp. 388-389.

${ }^{94}$ See: Ruben Enikolopov et all. (2011). "Media and Political Persuasion: Evidence from Russia." American Economic Review Volume 101:7. pp. 3253-85 
Gusinskiy. In 2002 another TV-channel TV-6, which was also controlled by Boris Berezovskiy, was closed down. The crew of the channel was able to win the broadcasters' contest and continued broadcasting for one more year. They also closed down in 2003 due to debt issues.

Thus, by 2003 all federal television channels were brought under state control directly or through associated business corporations. ${ }^{95}$ Controlled media has become a crucial part of building relations between civil society and the vertically integrated state apparatus in Russia. As Stephen White notes, "due to such control over media leaders of the country - Vladimir Putin and Dmitry Medvedev - have been receiving significantly larger coverage than their major political opponents." 96

The effects of such a policy were obvious. Mass-media has been involved in 'information campaigns' against politicians and political organisations. ${ }^{97}$ Control over major media also gives advantages to the pro-governmental forces. Political opponents usually receive less coverage on central TV and press than country leaders. Moreover, they are more often portrayed more negatively than political loyalists. However not only opposition political figures are targeted in the media. The media is used to soothe the political climate in the country. For example, during 2008-2010 financial crisis federal TV-channels were "playing down the gravity of the crisis; their coverage [was], as usual, focused on Russia's leaders, who [were] shown firmly in charge and taking good care of

\footnotetext{
95 Stephen White (2011) “Elections Russian-Style.” Europe-Asia Studies, Vol. 63:4, p.537

${ }^{96}$ Ibid. p. 535

${ }^{97}$ A series of reports and programs were released against Yuri Luzhkov - the former mayor of Moscow - after he was involved in open confrontation with president Dmitry Medvedev. For more details please refer to the digest: Informatsionnaia kampaniia protiv Luzhkova. LENTA.RU |Online| (URL: http://lenta.ru/story/luzhkov/) (Accessed on February 12, 2012.
} 
the people. ${ }^{, 98}$ Some protest actions (especially those in the Far East) were not reported on federal TV-channels. In the case of others (such as the Pikalyovo protests) the media portrayed the prime-minister Putin as the decisive factor in resolving the conflict.

In the mid-2000s the ruling political elite further strengthen its control over civil society in Russia by putting regulations on the activity of non-governmental organisations (NGOs) and passing anti-extremism legislation that put further constraints on the basic freedoms of citizens. Criticism of activity of international NGOs in Russia has been continuous throughout both terms of Vladimir Putin's presidency, and its intensity increased during electoral cycles. For example during the campaign for the 2011 Duma elections, Vladimir Putin accused foreign governments for their alleged support of Russian opposition and conducting hostile activities aimed at destabilization of the political situation in the country. ${ }^{99}$ Earlier on July 2, 2008, Vladimir Putin signed Decree No. 485 that substantially reduced the number of international NGOs that had been freed from taxation. Apart from financial impediments new regulations significantly complicated the registration procedures and improved state monitoring, audit and, thus, control over their activities.

Broad interpretations of the law on extremism furthermore allowed implementation of state control on spheres of public activity that are not regulated through institutional leverage. Famous Russian ombudswoman Lyudmila Alekseeva

\footnotetext{
${ }^{98}$ Maria Lipman (2009). Media Manipulation and Political Control in Russia. Russia and Eurasia Programme: REP PP 09/01 London: Chatham House p.15

${ }^{99}$ For more details refer to: Address of the prime-minister of Russia Vladimir Putin to the annual convention of the United Russia party, November 27, 2011. |on-line| (URL: http://premier.gov.ru/events/news/17248/multiscripts.html) (Accessed: February 10, 2012)
} 
called this law as "an additional tool for authorities in their struggle against dissenters.",100 Experts outline that " $[\mathrm{t}]$ he broad discretion given to authorities in prosecuting extremist crimes under the criminal code raises concerns that it will be used to silence critical speech, minority opinions, and other forms of expression." ${ }^{\text {101 }}$ By selective use of this legislation, the authorities are able to seize activities of various non-institutionalised political and social movements, for example take down blogs on the internet. There were even proposals to introduce censorship on internet communications. ${ }^{102}$ Apart from controlling the virtual sphere, the authorities changed the practice of endorsement of public meetings. Local public administrations substituted the de-jure notifying principle of endorsement with de-facto authorizing-based one. Among the most notorious cases that illustrate how the state controls the public sphere, are the continuous denials to conduct a parade of sexual minorities in Moscow during Yuri Luzhkov's tenure and a ban on processions and meetings organized by two opposition political movements: Strategy31 and Marches of Discordants (Marsh Nesoglastnykh).

All these measures show the voraciousness of top state officials to extend their control beyond the traditional bureaucratic machinery. They use a variety of tools, both formal and informal, in order to gain control over major processes that occur in Russian society. The doctrine of sovereign democracy furthermore justifies such state

\footnotetext{
${ }^{100}$ Lyudmila Alekseeva (2009). Press-conference "Prizrak kommunizma protiv istoricheskoi khroniki”" [online] (URL: http://www.newsland.ru/news/detail/id/413625/) (accessed February 12, 2012).

${ }^{101}$ Matthew Schaaf, Tatiana Lokshina (2009) An uncivil approach to civil society: continuing state curbs on independent NGOs and activists in Russia. Human Rights Watch. p.51

${ }^{102}$ See for example: October 8, 2004. Rastushchii internet v Rossii khotiat priruchit. CNEWS.RU |online| (URL:

http://www.cnews.ru/news/top/index.shtml?2004/10/08/166418) (Accessed February 12, 2002)
} 
penetrations into civil society and uses arguments of uniqueness of the Russian path of development, as well as the necessity to protect already achieved stability from external threats.

\section{Conclusion}

The first two decades of the post-Soviet era in Russia were signified by a radical turn in the development of the political system of the country. The liberalization of 1990s resulted in a return to, as some scholars characterize it, authoritarian political trends. ${ }^{103}$ Changes affected not only the political system but also other spheres of public life. The political reforms discussed in this Chapter outlined a major vector in reshaping the political and social context in Russia in the $21^{\text {st }}$ century. Increased state control over the main domains of public life in Russia has been the crucial feature of political development of the Russian Federation for the last twelve years.

This Chapter proposed a peculiar classification of the wide spectrum of political reforms in the form of the conceptual pyramid of governance. The middle layer of this pyramid included reforms of the state institutions and the corps of state officials. By means of logic of the political process in the country, the state administration should become a very important link in the chain of governance between the institutes of grassroot, municipal authorities and a highly centralized and unified system of central governance. At the same time the dominant political ideology has become the concept of the 'vertical of power'. According to its logic in the list of political values, stability and order were given priority over other values such as political freedom, liberal democracy, openness and others. Such a peculiar 'social contract' between Putin and the ruling elite

\footnotetext{
${ }^{103}$ See for example: Thomas Ambrosio (2009). Authoritarian Backlash: Russian Resistance to Democratization in the Former Soviet Union. Farnham: Ashgate.
} 
on the one hand and citizens on the other also depended on effective public administration. The latter should effectively implement policies issued from the top tiers of the state apparatus and, at the same time, transmit aspirations that the civil society expresses regarding further development of the country. Therefore, the success of such a vertically integrated political corporation as the Russian state is highly dependent on flexible and efficient bureaucracy.

One aspect of the comprehensive transformation of the Russian state was deliberately taken out of the discussion in this Chapter, namely the aspect of economic development. Completely omitting it however would not be correct, due to its importance in explaining the need for a reform of public administration. The efficiency of implementing reforms in economic and social spheres to a greater extent depends on prompt and proper execution of its duties by the state apparatus, specifically according to the norms and rules prescribed in the legislature. Mentioning these reforms is important for a better understanding of the objectives and expectations that were put in the core of the reform of public administration. In one of the key documents of this reform - The Conception of Administrative reform in 2006-2008 - the economic factors of public administration are put in the core of major proposed measures. It is said that the goal of the reform is "to reduce governmental penetration into the economic activity of entrepreneurs, and to reduce excessive state regulation [of it]."104

It is reasonable to recall that one of the key political tasks for Vladimir Putin's first presidential tenure was the separation of political and economic spheres. 'Equaldistancing (ravnoudalenie) of the oligarchs' was perhaps the first concern in the sphere of

\footnotetext{
${ }^{104}$ See Resolution of the Government of Russia \# 1789-p from October 25, 2005. "Kontseptsia administrativnoi reformy v Rossiiskoi Federatsii v 2006-2008 godakh"
} 
the national economy addressed by Putin's administration. By the accomplishment of this undertaking, a new form of relationships between the state and economic agents was established. The state apparatus showed its ability to resist the influence of capital. Furthermore, the vertical vector of communication between the officialdom and the business community has become quite obvious.

The second phase was the increase of government penetration in the economy. The state started to control key sectors of Russian economy (particularly the natural resource sector) through a conglomerate of state owned enterprises. The bankruptcy of YUKOS and its further takeover by the state owned Rosneft was perhaps the most notorious, but obviously not an isolated incident. The ability of the state apparatus to control economic relations became obvious during the 2008-10 economic crisis when administrative decisions made by public officials (prime-minister, or governors) interrupted business cycles in order for the state to be able to maintain social stability. ${ }^{105}$

Given the above observations of political transformations during Putin and Medvedev presidential tenures, clearly implies that building the 'power vertical' was the major feature of the regime in the last twelve years. Indeed it significantly reshaped the structure of the state. The 'power vertical' transformed the nature of political communication in the country, making the central government the ultimate actor. Political consequences of this transformation need further rethinking. Sustainability of this regime which was quite often called authoritarian, is also under question after the

${ }^{105}$ For more details refer to: Joan DeBardeleben and Mikhail Zherebtsov (2013) "Economic Crisis, the Power Vertical, and Prospects for Liberalization in Russia." In DeBardeleben, J., Viju, C. (eds.) (2013) The Economic-Financial Crisis in Europe: What It Means for the EU and Russia. New York: Palgrave Macmillan; and Nikita Krichevskiy (2009) Postpikalevskaia Rossiia: novaia politiko-ekonomicheskaia real'nost. Moscow. 
2011 Duma elections. Undoubtedly however, this political system shares some responsibility for the troubled nature of the reform of the state apparatus and civil service.

Thereby, the 'vertical of power' appears to be the "overarching metaphor" that indicates domination of the state in almost all crucial spheres of public life. 


\section{Chapter II. Public administration and civil service in post-Soviet Russia: the need for reform.}

The system of public administration of the Russian Federation appears to be at the core of the political reforms that took place at the beginning of the $21^{\text {st }}$ century. According to the plan of rebuilding of state institutions - as proposed by the second Russian president - the state bureaucracy is attributed a crucial role in facilitating economic and social development of the country, as well as in ensuring effective communication between the different layers of the political system. Undoubtedly, in order to perform such a task, the administrative machinery itself had to be substantially advanced and become a rational and an efficient political institution. Yet by the time the reform of public administration was launched, it had been plagued by many deficiencies. Some of the drawbacks were inherited from the Soviet period, while others were the result of unsystematic and, quite often responsive - adaptation to post-Soviet political and economic realities. The tumultuous processes that occurred in the public sphere at this time - to a great extent—-determined the conditions of institutions of public administration, and thus stipulated the design of the reform, its implementation and the potential causes of its failure.

This chapter is focused on the major processes that took place in the sphere of public administration and governance between 1991 (the year when the Soviet Union was dismantled) and 2004 (the beginning of the reform process of in the Russian public sector). These fourteen years were signified by two fundamental processes: 1) overcoming Soviet legacies of the principles of governance and 2) searching for a new identity of the Russian state apparatus. Whereas the purpose of the first chapter of the 
dissertation was to determine necessity — and even inevitability—of the reform of public administration from the logic of the program of reforms as proposed by Vladimir Putin, the second chapter explains the logic of the reform by analyzing the internal deficiencies and inconsistencies of the institutions of government in late Soviet - early post-Soviet period.

\section{The Soviet legacy of the Russian government}

The nature of state in the Soviet Union was a quite significant impediment for development of Russia's own public administration in the early 1990s. Such factors as multi-layer composition of state organisations, omnipresence of the Communist party and the so called administrative-command system of public administration ${ }^{1}-$ influenced (if not determined) the first actions of Boris Yeltsin's independent administration. Another factor was social, ethical and even the habitual specificities of the Soviet style bureaucratic apparatus. At the lower strata these specificities determined the modus vivendi of the state apparatus and its arduous adaptation to the new realities of the freemarket and democratic society. In regard to the upper level bureaucratic organisation, Soviet managerial principles resulted in the creation of elite-like parties, and the continuation of bureaucratic 'nomenklatura'. It was even argued elsewhere that the Soviet bureaucratic elite actively participated in the process of dismembering the Soviet Union, as it planned to participate in the redistribution of state property. ${ }^{2}$ Furthermore, if the structural and institutional composition of the Soviet state was transformed to at least some extent - its civil service was actually inherited by Russia after the collapse of the

${ }^{1}$ The term was introduced by Soviet famous economist Gavriil Popov in his article " $\mathrm{S}$ tochki zreniia ekonomista" in Nauka i Zhizn' No.4 1987.

${ }^{2}$ Aleksander Obolonskii. (1996) "Postsovetskoe chinovnichestvo: kvazibiurokraticheskii praviashchii klass.” Obshchestvennye nauki i sovremennost'. No.5 pp. 5-15. 
USSR. These factors are worth deeper investigation because of their influence on the post-Soviet development of public service in Russia in the 1990s.

First of all, the system of institutions of the Soviet state was quite complex. To begin with, the USSR was a federation that included the Russian Soviet Federative Socialist Republic — itself a federation — as a member state; and the city of Moscow— itself having a special status as the capital of the USSR, the Russian Federation and the Moscow oblast. This complexity was the result of contradictory nation and state-building processes in 1917 - early 1920s. According to Vladimir Lenin's decree, issued in $1918^{3}$, the previously unitary state of imperial Russia was transformed into a federation. The later unification with the Ukrainian, Belorussian and the Transcaucasian Soviet Socialist Republics formed the Soviet Union. After several further mergers and demarcations, the Soviet Union obtained its well-known composition of fifteen republics.

Such versatile political processes could not help but affect the process of organization of the state service in the territory of the Soviet Union and RSFSR. Furthermore, the socialist nature of the new state demanded a peculiar form of governance that was able to oversee both social and economic processes in the country being under political control of the Communist party. The system of state institutions was stabilized in the 1930s and remained constant until the dissolution of the Union. ${ }^{4}$

The system of executive power of the Soviet Union was quite complex. Russian historian Natalia Nosova outlines three major layers of the state apparatus: superior

${ }^{3}$ See: "Deklaratsiia prav trudiashchegosia i ekspluatiruemogo naroda." January 5, 1918. in Dekrety Sovetskoi vlasti. Vol. I. Moscow: 1957.

${ }^{4}$ Sergei Kara-Murza (1999). Istoriia sovetskogo gosudarstva i prava. Moscow: "Bylina" 
institutions, central and local organizations. ${ }^{5}$ The former were institutions that performed political functions and possessed compétence d'autorité. According to this taxonomy, superior organizations - such as the Supreme Soviet for instance, were leading the state by performing mostly political functions. Central bodies, which included mostly executive organs (ministries, committees etc.) performed merely managerial functionsbeing bounded by the vertical principle of accountability. Some sort of local selfgovernance was present in the Soviet Union - with local councils (soviets) of people's deputies and their subordinate executive offices. Thus, from a juridical point of view, the Soviet Union had a very developed, but complicated system of state institutions and political relationships.

Functional capacity and effectiveness of the Soviet Union were supported by some crucial features. First and foremost was communist ideology - as institutionalized in the organizations of the Communist Party of the Soviet Union (CPSU). The multilevel hierarchical system of the CPSU allowed effective supervision of social and economic processes at all stages: from central to regional and all the way down to local. Basic grass-root organisations of the communist party—district or town/city committees of the CPSU - were able to supervise and control actual institutions of the lower level of executive power - executive committees of councils of public deputies. District and town/city committees themselves were under control of the party's regional committees; and the latter were subordinate to the republican committees of the Communist party. Effectively, committees of the communist party were performing the functions of executive bodies, substituting them. The Party apparatus was the binding factor that tied

\footnotetext{
${ }^{5}$ Natalia Nosova (2000). Istoriia gosudarstvennogo upravleniia Rossii (IX-XX vv.).
} 
together this de-jure highly decentralised system of people's councils. This system had become known in historiography as a party-state model of governance: "[i]n functional terms the real cabinet of the Soviet political system is the party Politburo, the real parliament is the party Central Committee, and the real prime-minister is the party General Secretary."6

More importantly, institutions of the Communist party dominated the economy as well. Primary party organisations that were called 'party cells', existed in all economic bodies across the various sectors of national economy, from agricultural to heavy industry and science. These party cells were involved in the decision-making process, acting as a sort of party control over the management and workers. Besides, chief executives of the majority of Soviet economic units were active members of the party, and thus were accountable to the regional head of the CPSU. Thus in building a new system of governance, the independent Russian political elite had to overcome the absence of binding factors that were embedded into the ideology of the communist party, and more importantly - in its apparatuses.

The second factor was the specific model of the centrally planned socialist economy. The bureaucratic machine and institutional organization of the Soviet state were specifically designed to deal with an economic system of this sort. Sectoral organization of the economy was considered the most effective structure of the system with the state's exclusive ownership rights on the means of production. Thus the state's dominance over the national economy demanded a specific form of administrative-

${ }^{6}$ Jerry F. Hough and Merle Fainsod (1979). How the Soviet Union is Governed. Cambridge: Harvard University Press., p.362 
command bureaucracy, which was capable of managing economic processes in a highly centralized manner. People's commissariats, and later ministries, were the highest central sectoral bodies of public administration. They were responsible for conducting decisions made by the top state officials on the basis of carefully developed five-years (seven-years on the early stages) directive plans.

The sectoral system of managing the economy determined the peculiarity of the various bodies of Soviet public administration. 'Economic' ministries, organized according with the sectoral principle, were positioned alongside more traditional, functionally oriented ministries and committees. The specific function of the socialist system, with the state responsible for actual day-to-day management of economic processes, demanded a highly branched and quite numerous public service. The system of government in the USSR was very mobile and adaptive towards the needs of the socialist state. Thus, sectoral bodies were subjected to numerous consolidations and separations throughout their existence. On the eve of the dissolution of the USSR there were 56 central administrative bodies: ministries and committees. ${ }^{7}$ There were national and [joint] union-republican institutions. The former ministries and committees fulfilled their functions on the entire territory of the USSR with its territorial branches directly accountable to Moscow. The latter organisations delegated administrative functions to the regional ministries and committees controlling and directing them. Although being quite extensive, this system of government was able to avoid duplication of functions and maintain vertical integration.

${ }^{7}$ See: The Law of the USSR No. 146-1 from June 27, 1989 "O vnesenii izmenenii v Zakon SSSR “O Sovete Ministrov SSSR”. 
The structure and functional capacity of the executive agencies corresponded with the principles of organisation of production processes. For example, the entire production cycle in heavy industries (from procurement to off-take) was put under direct control of the central ministries. This allowed them to form highly structured production complexes within the national economy when a particular ministry or state committee supervised an entire sector of economy. ${ }^{8}$ In some instances controlling functions were performed by the federal ministries; in others - they were divided among the republican executive bodies. In theory such organization of production was supposed to be efficient for a centrally planned economy. An optimized structure allowed excluding organisations whose purpose would be the provision of various intermediary market services. Directive planning controlled the entire production process including pricing. Thus, all agents involved in a process of production were connected with each other through state agencies. In addition, in some instances such an organization would be allowed to reduce production costs by minimizing managerial expenses and building large consolidated industrial complexes. Indeed the Soviet economy was famous for towns formed around large enterprises and giant industrial conglomerates consisting of various factories united into a singular production chain. However, this structure increased sectoral isolation and departmentalism ('vedomstvennost') and influenced the bureaucratic culture significantly by promoting closeness and factionalism within the bureaucratic community. Hypertrophied vertical ties and lack of support of horizontal connections further complicated the internal processes and raised concerns about the state apparatus as a unified body.

${ }^{8}$ Sergei Kara-Murza. (1999). op.cit. 
The government of RSFSR (as well as the governments of other Soviet republics) was built into the system of the centrally planned economy. However, due to the federative nature of the republic, it replicated the structure of the federal government. There were ministries and committees subordinate to the government of USSR; in addition, there were bodies accountable only to the republican government.

It is quite difficult to quantify the actual number of public officials in the Soviet Union for political and economic reasons. As Barabashev and Straussman noted, "the personnel system of the Soviet Union was dominated by the Communist Party apparatus and did not in any meaningful way resemble Western-style civil service systems." Indeed, it is hard to assess and structure the Communist party apparatus in terms of the classical definition of bureaucracy. Particularly, because of the state's dominance in economy, it could be considered the primary employer for an overwhelming majority of people involved in national production. It is also quite complicated to distinguish civil service from the state's management apparatus. The planned economy demanded directive control from bureaucratic organisations (ministries, committees etc.) over productive organisations (industrial plants, state farms etc.). By this logic, managerial personnel were deeply intertwined with public officials and were all often described as part of the 'state bureaucracy'.

However, for the purposes of this dissertation it is worth delineating the direct employees of the state apparatus and provide their quantitative characteristics. Thus,

${ }^{9}$ A. Barabashev, J.D. Straussman (2007). "Public service reform in Russia, 1991-2006." Public Administration Review, 67(3), p. 373. 
according to the 1989 statistical review ${ }^{10}$ on the eve of the dissolution of the USSR there were approximately 1.5 million employees who can be considered public officials in contemporary terms. This gives the ratio of less than 1 per cent of the total working age population of the Soviet Union. The ratio increases to $9 \%$ if all other managing and white collar personnel (which is often attributed as civil servants) is included. This increased cluster would include employees involved in the production and distribution of civil services (e.g., teachers, medical personnel, etc.). These statistics question the common allegation that the Soviet state apparatus was plagued by excessive bureaucratization. Moreover, during the 1980s, the Soviet Union followed the worldwide trend of debureaucratization and 'shrinking the government'. The fact that in the last decade of the existence of the Soviet Union, its bureaucratic apparatus shrank by almost 30 per cent (roughly 2.2 million employees), seems quite a significant achievement.

The Soviet type of public administration was distinguished by a very peculiar form of manpower policy aimed at rotation, recommencement and recruitment of high ranked state officials. This phenomenon was given the name nomenklatura and was the unique feature of the Soviet system of governance. Nomenklatura is defined as "the list of the most important [governmental] positions; with the candidates for these positions are considered, recommended and appointed by the party committee (district, city, regional, etc.)." ${ }^{11}$ Voslenskiy argued that the major criterion for appointment within the

${ }^{10}$ See: Goskomstat SSSR (1990). SSSR v tsifrakh v 1989 godu (Kratkii statisticheskii sbornik). Moscow: Finansy i Statistika.

${ }^{11}$ Mikhail Voslenskiy (2005). Nomenklatura. Gospodstvuiushchii klass Sovetskogo Soiuza. Moscow: "Zakharov". 
nomenklatura was personal loyalty to the superiors and to the system. Indeed the vertical vector of political communication and mobility was prevalent in the communist system.

The definition of nomenklatura makes it impossible to compare it with any other form of elitist organisations that can be found in different countries and across political regimes. It included functionaries from various sectors of the national economy and public administration tied together by communist party affiliation. According to Mikhail Voslenskiy there were around 750 thousands members of this community, with only 250 thousands being political apparatus officials, while the others represented the economic and scientific sectors. However, being relatively scanty, the nomenkatura class “established its undivided monopoly on making decisions not only on the crucial but also on inessential questions in the country." 12 The whole nature of this 'association' allowed it to penetrate and control almost every sphere of public life in the Soviet Union. One may argue that the seclusion of the Soviet elite, its separation from the public, made it organisationally ineffective and contributed to its demise.

Thus, the state apparatus was heavily involved in the economic life of the country. The directive way of managing centrally planned economic processes and an exaggerated top-down vector of administration were the significant impediments to building a public administration that was capable of being efficient in a decentralized market economy. Indeed all these aspects of Soviet governance structures and process, were the substantial factors, and to some extent, determined the route of post-Soviet development of Russia.

The last years of the USSR were marked by numerous conflicts within and between the republics, many of them being ethnic in nature, forceful secession movement

\section{Ibid.}


in the Baltic republics, Armenian-Azerbaijani conflict over Nagorno-Karabakh, ethnic clashes in Georgia and Moldova. Furthermore, the Russian Federation, which inherited the Soviet principles of state-building, also suffered from powerful separatist movements. Such rapid and violent dissolution of the USSR raised the issue of the mechanisms which for decades had restrained these movements. Generally speaking, it was a major task for the new Russian administration to overcome the inconsistencies of the old regime with the new principles of economic management and social relations. These three factors state's dominance into the economy, nomenklatura style government elite, and specific form of bureaucracy - posed obvious difficulties, and had to be overcome in the course of the reforms proposed by Yeltsin's administration.

\section{Crucial characteristics of the system of public administration in Russia:1991-2004}

As discussed above, the government of the largest Soviet republic inherited almost every aspect of the Soviet system of governance. At the same time however, being the subordinate part of the larger apparatus, it lacked some significant structural and functional characteristics. Moreover, due to its significant territory and the overwhelming importance for the national economy, the governmental bodies of RSFSR were deliberately kept weak; and control and supervision of their activities was more intensely done by the Soviet Union government than is the case of other union republics. ${ }^{13}$ At the same time, the institutions of the Communist party of the republic, remained considerably influential - especially its Moscow city committee. Apparently, such manpower politics

${ }^{13}$ Iulia Shevchenko (2004). The central government of Russia: from Gorbachev to Putin. Burlington: Ashgate., pp. 39-40 
was necessary for the Union authorities in order to oversee major economic processes in the republic and thus reduce threats of potential strengthening of the regional authorities.

In the late 1980s however, the central state apparatus was unable to control the increasing centrifugal tendencies that had begun on the periphery of the Union and later spread to the central parts of the country. Furthermore, the political elite of RSFSR benefited from this situation. Responding to the weakening oversight from the Union government, accompanied by the shrinking hegemony of the republican Communist Party state authorities, the regional elite significantly improved its control over the political, social and economic processes in the republic.

For more than seventy years the Soviet Union had almost all legal attributes of a parliamentary republic with the Supreme Soviet of People's Deputies being the supreme government institution of the country. However, it was under the total control of the Communist party, parliamentary superiority was only de-jure and not de-facto. The same structure was replicated in RSFSR, and with an abandonment of total party control in early 1990, the republican Supreme Soviet of the RSFSR had become a very powerful political organization. Between the years preceding the dissolution of the Union and the October 1993 constitutional crisis, the Supreme Soviet of Russia was quite a significant actor on the Russian political landscape. As an institution that performs its activity on a regular basis, it was subordinate to the Congress of People's Deputies, which emerged on the Russian political landscape in the background of increasingly autarkic attitudes and existed between 1990 and 1993. The Congress gathered sessionally and included more than a thousand deputies, and was thus quite cumbersome and inflexible for everyday legislative activity. Indeed it gathered several times a year to address the most crucial 
issues. With this Congress - the Supreme Soviet dichotomy in the RSFSR reiterated the governance scheme used at the union level.

As a result of the political reforms undertaken by the Gorbachev administration, the Congress that was elected in the Spring of 1990 was no longer dominated by the Communist party and became the place for intense political debates. Such a radical turnabout had become possible due to an abandonment of the exclusive role of CPSU in political life of the country, which had been prescribed in the $6^{\text {th }}$ Article of the Constitution of USSR. Amendments to the Constitution introduced in March 14, 1990 allowed the establishment of alternative political parties. Major democratic forces that supported Russia's path to independence, represented quite influential factions in the Congress. Between sessions of the Congress, the Supreme Soviet performed duties similar to those of a regular parliament. It adopted the bicameral structure in 1989 due to amendments to the republican Constitution. The legal status of the Supreme Soviet made it the only powerful institution of the early 1990s until the introduction of the post of the president of RSFSR.

Republican executive agencies were subordinate to the Supreme Soviet. The government of RSFSR - the Council of Ministers - in the late Soviet period of 19901991, was merely the result of a political bargain between major political forces represented in the Congress. The entire process of forming of a cabinet was quite slow. In addition, the Supreme Soviet quite intensively exercised its right to oversee the activities of executive bodies. ${ }^{14}$ As Shevchenko notes: "[p]arliamentary organs usurped decision-

\footnotetext{
${ }^{14}$ Records of the $3^{\text {rd }}$ session of the Congress of People's Deputies. Rossiiskaia Gazeta, April 5, 1991
} 
making prerogatives of the government..." ${ }^{15}$ The situation was worsened by the inconsistency and lack of structural clarity within the government, when different governmental institutions overlapped each other's functions and some of the positions were allotted on the basis of personal and political loyalty rather than on professional credentials of the incumbents. All this significantly hampered efficient performance of the government.

At the very same time, the efficiency of the republican government was a very important factor for an effective opposition to the Union government. Thus, Russian leader Boris Yeltsin demanded more autonomy for the executive body - on the one hand understanding the importance of rapid and efficient economic modernization, and on the other hand, trying to enforce his personal authority. Repeating the governmental structure of the Soviet Union, the office of the President of Russian Soviet Federative Socialist Republic was introduced in $1991{ }^{16}$ The elections took place on June 12, 1991 giving Yeltsin the decisive majority of $57.3 \%$ of public votes.

Creation of the presidential office, however, only further obscured the status and authority of the government. The system of government created in 1990, resembled characteristics of a parliamentary-presidential republic. According to the law "On the President of RSFSR" (adopted in April 24, 1991), the president was pronounced the chief of the executive body. As the head, he was given the authority to appoint the primeminister (with the approval of the Supreme Soviet) and to administer the government (named Cabinet of Ministers). The institution of the President of RSFSR was however,

${ }^{15}$ Iulia Shevchenko. Op.cit. p. 49

${ }^{16}$ The Law of RSFSR No. 1098-1, from April 24, 1991 “On the President of RSFSR”. 
quite weak. Thus, many fundamental decisions of the President had to receive approval of the legislative branch. For example, the President needed parliamentary confirmation of a Cabinet resignation. Moreover, the Congress of People's Deputies, according the Constitution enjoyed authority over some crucial governance (executive in particular) issues, such as determining of the internal and foreign policy of the Russian Federation. At the same time, the President did not enjoy the same level of authority and independence as did the Congress. He did not have the right to dissolve the parliament. The latter however, had the right of impeachment. ${ }^{17}$

Therefore, this parliamentary-presidential dualism was the result of a rapid evolution of the system of governance in the Russian Federation in 1990-91. A few factors contributed to the ascent of the significance of the executive branch. First of all, within the Union, the republican government was a supplement to the joint executive system of the USSR and was heavily controlled, and on some accounts, it was amalgamated within the Communist party apparatus. Boris Yeltsin, together with his closest allies, demanded a strengthening of the republican government —at the expense of the Supreme Soviet - as a tool of necessity in their struggle against the Union center. The process of disintegration, which plagued the USSR during these years, demanded that Russian authorities fill those governmental functions that were quickly becoming vacant due to decline of authority of Union institutions. Thus, more control over the socioeconomic and political processes within the country, inevitably made the republican government quite an important institution. Secondly, because of the rapid economic

${ }^{17}$ The Law of RSFSR No. 1098-1, from April 24, 1991 "O Prezidente RSFSR". Article 10. 
decline and thus the need for rapid reforms, the government was granted some necessary operational freedom. The parliament was not able to control day-to-day activities of the government, making it less dependent to external intervention. The system of deputies' inquiries (deputatskii zapros) - the only legitimate tool for parliamentarians to control the government - was largely ignored by the ministries. Finally, the rise in importance of the government, was due to some characteristics of the personality of the first Russian president. Being quite an authoritarian leader ${ }^{18}$, Boris Yeltsin, after becoming the head of the executive branch, wanted to control it exclusively. Thus, he was looking for ways to eliminate those functions of the Supreme Soviet that were aimed at controlling the government and limiting the activities of the president. This trend was later legitimized in the Constitution of 1993, which ended the parliamentary-presidential dualism and proclaimed a new presidential (or as some experts assume, super-presidential) form of governance in the country. Obviously the system of governance that existed in Russia in 1990-93 did not foster stability of the political system in the country. In light of the deteriorating economic situation and uncertainties in the division of power, the conflict between the executive and legislative branches became almost inevitable.

The year 1992 was quite important for the Russian economy as well as for the state. The programme of rapid economic reforms, known as 'shock therapy', was brought in by a group of young reformers led by Yegor Gaidar. Supported by the 'Democratic Choice' faction in the Supreme Soviet, the newly elected president Boris Yeltsin headed

${ }^{18}$ Some researchers and contemporaries characterize Yeltsin's style of governance as authoritarian. See for example: Alexander Khinshtein (2006). Yeltsin. Kreml', Istoriia bolezni. Moscow: Olma Media., pp. 81-83; or Lilia Shevtsova (2000). “Ot Rossii Yeltsina k Rossii Putina." Contemporary Europe Vol.4. pp.20-32. 
the government, giving a 'green light' for the course of liberalization of the Russian economy. This was initially known as the Yeltsin-Gaidar reforms. Due to its monetarist ideological stance, the programme included some measures that affected Russians quite significantly, and in some instances negatively. Among them were: liberalization of prices, freedom of trade, substitution of directive planning with state contracts, and privatisation. In terms of state building, the reforms proposed cuts of budget spending and minimisation of the state apparatus. These reforms resulted with a rapid deterioration of economic conditions in Russia throughout all of 1992. First results produced hyperinflation and pauperization of the majority of Russian people. In such a situation, massive anti-governmental protests took place in various regions.

Neither the parliament nor the president wanted to take responsibility for unpopular reforms. Thus, both institutions of high power decided to distance themselves from the government. In the middle of the year, Boris Yeltsin delegated his authority as head of the government to Yegor Gaidar. The latter became acting prime-minister. The unpopularity of the reforms did not allow the Congress, which gathered in December 1992, to approve Gaidar's nomination. The Congress agreed with the compromising figure of Viktor Chernomyrdin. The newly elected prime-minister suited both the parliamentarians for his administrative background, and Yeltsin for his adherence to the Gaidar reforms. Yegor Gaidar remained in office, receiving the post of the first deputy prime-minister. The mainstream course of reforms was continued, however due to political reasons it was transformed.

Besides structural uncertainties, the governmental apparatus itself was another crucial impediment for efficient decision making. Many cabinet ministers later 
complained that their many innovative attempts were systematically neglected by this conservatively conditioned apparatus. ${ }^{19}$

The conflict between the branches of power resulted in the October 1993 Constitutional crisis which ended with victory for the President, the dissolution of the Congress and Supreme Soviet, and a proposal of a referendum on a new constitution. The referendum was conducted on December 12, 1993, with 58 per cent of citizens approving the Constitution which established a new super-presidential form of government. According to the new system, the abilities of the bicameral parliament-the Federal Assembly - to intervene or control the cabinet, were significantly reduced. The Duma was given the right to participate in the appointment of the prime-minister. It was also granted the right to vote for non-confidence of the cabinet. However even these liberties were restricted by the president's ability to dissolve the parliament. The new Constitution quite significantly strengthened the executive branch and the institute of the president.

The new principles of the functions of the state service were established with the adoption of the new Constitution. The president became the head of state, and thus all central executive functions were transferred to the federal government and its regional branches. The president supervised the work of the executive organs, but was able to avoid personal accountability for it. The office of the President took formal control over the government, significantly reducing the role of the legislation in the operative governance of the country. The constitution clarified zones of authority of all branches of power subordinating the government to the president and leaving the parliament with

${ }^{19}$ See for example: Ivan Silayev. Rossiiskie vesti; June 1991; and Nikolai Fedorov in Report on the USSR. Vol. 3(1), 1991, p.6 
only two significant controlling options - to dismiss the Cabinet (though a vote of nonconfidence), and impeach the President. The latter however, involves a very complicated procedure that made it almost impossible for the legislation to question the President's authority. The government however, was more vulnerable. Thus in the mid-90s, there were attempts to either dismiss the already approved government, or reject a presidential nominee. It must be said however, that only in 1998 was the Duma able to influence the President's choice of premier, and lobbied the coalition government to have Evgeniy Primakov appointed as prime-minister. This was mainly due to an ongoing economic crisis in the country and significant presence of the opposition in the State Duma.

In terms of governing the country, the executive branch has had priority functions, with the State Duma almost always playing a marginal role. The Duma has almost never confronted a President's appointment for the prime-minister's office. Nor has it really demanded his resignation and undertaken the necessary steps in order to assure it. Only Viktor Chernomyrdin's first premiership was seriously challenged by parliament. In 1995 the State Duma passed a vote of no confidence of his government; however it did not corroborate its claim, anticipating the president's decision to dissolve the Duma. According to the regulations, the vote of no confidence does not result in an immediate dissolution of the government. However if the Duma passes another vote within the next three months following the first attempt, the president must dissolve either the government or the parliament. Viktor Chernomyrdin himself demanded the Duma vote for the second time the very next day—after the first voting — however the deputies did not reaffirm their earlier decision. The second time the Duma rejected Chernomyrdin was in 1998, when Yeltsin attempted to return him to the government. Parliamentarians 
rejected his candidacy twice and after consultations Chernomyrdin was replaced by Evgeniy Primakov, who was approved by a majority of voters. The Duma's strong position is explained by the extreme unpopularity of the cabinet and the President's office after the default and subsequent financial and economic crisis in the country, on the eve of the electoral cycle. Another, but rather unsuccessful attempt to vote for no confidence occurred in 2001 when the CPRF faction in Duma, initially supported by the progovernment faction of the Unity party, put this proposal to the vote. However, the initiative failed: only 127 deputies supported it. In all other situations, threats to utilize the vote of no confidence to the parliament's agenda were never executed. Overall, since adoption of the new Constitution, there have been six attempts to force the resignation of the cabinet, undertaken by the parliament.

Separation of the offices of president and government allowed the latter to become the arena for active and intensive political bargaining between the executive and legislative branches. This is especially true regarding the process of approval of primeminister and some key ministers in the cabinet. Like Viktor Chernomyrdin, another of Yeltsin's protégé, Sergei Kirienko, faced rejection of his candidacy for the premiership in 1998. Although during the second attempt, Kirienko received even fewer votes than during the first round of voting (115 to the first round's 143), president Yeltsin introduced him for the third time, ultimately menacing the Duma with dissolution and preterm parliamentary elections in the country. The approval of Sergei Kirienko by parliament, de-facto reaffirmed the superiority of the executive branch in the Russian system of governance. However, constitutional mechanisms of parliamentary control over the government made the latter a very prominent and rather influential political 
institution. Regardless of strict presidential oversight, the government used to be (and still is to some extent), the arena for political bargaining among the various political and economic groups. This tumultuous nature of the government can be traced to arrangements of executive personnel.

The introduction of the office of president in 1990 changed the balance of power in the country and fostered the 1993 political crisis. After the adoption of the Constitution in 1993 which significantly legitimized and enhanced the authority of the president, the political status of government was also substantially affected. Primarily it related to the functional capacity of the cabinet, vis-à-vis another executive unit - namely the Administration of the President. According to the Constitution (Article 83) and respective legislature ${ }^{20}$ the purpose of this state institution is facilitation to the president in fulfilment of his constitutional duties. At the same time, the duties of the president often correspond with those of the government. Thus responsibilities of the cabinet and the administration are not fully separated and this situation of functional uncertainty "begets serious deficiencies in governance." ${ }^{21}$ Although the president oversees and controls activities of the government, he does not have authority to act as the prime-minister and for example manage the work of the government directly. ${ }^{22}$ This formal separation of responsibilities within the executive branch of power was not made clear and was conducive to the rise of the presidential administration.

${ }^{20}$ Here I refer to the "Regulations on the Administration of the President of the Russian Federation" in four consecutive editions issued in the form of presidential edicts: No.273 from February 22, 1993, No.117 from January 29, 1996; No.1412 from October 2, 1996; and No.490 from April 6, 2004.

${ }^{21}$ Lev Okun'kov (1998). "Pravitel'stvo i Prezident: grani vzaimodeistviia." Journal of Russian Law. No.9

${ }^{22}$ Ibid. 
Yet the question of division of authority and responsibilities within the executive branch, still remains a topic for academic and public discussions. Some experts believe that the president is fully responsible for the executive officialdom. ${ }^{23}$ Others suggest that there exists a separation of strategic political and socio-economic functions. ${ }^{24}$ The president enjoyed control over the former, whereas the latter was transferred to the government. For the first time the president dissociated himself from the government in 1992 after the failure of Yegor Gaidar's radical-liberal plan of economic reform. This trend continued throughout the entire presidency of Boris Yeltsin.

The government seemed to focus on short-term economic policies. It looked like it did not pay much attention to the potential strategic outcomes. Being made responsible for everyday social and economic development the government was forced to introduce difficult and often criticized measures in order meet its liabilities to provide stability of budgetary policy. Outcomes of such economic programs such as "loans-for-shares" or issuance of GKOs (Government's short term obligation or treasury bills) produced a lot of criticism among the experts, the political opposition, and the general public. "The pyramid of GKOs" was named the major factor that led the national economy to the default and subsequent economic crisis in August 1998. All these measures were aimed primarily at fulfilling income gaps in the budget.

At least in theory, there is some logic for such separation of responsibilities and duties within the executive branch. The government, enforced by respective ministries,

${ }^{23}$ See for example: Iulia Shevchenko op.cit. p. 105

${ }^{24}$ Lev Okun'kov (1998). "Pravitel'stvo i Prezident: grani vzaimodeistviia." Journal of Russian Law. No.9 and Lev Okun'kov (2001). Pravitel'stvo i Prezident: v mekhanizme gosudarstvennoi vlasti. Journal of Russian Law. No.9 
has the capacity and the expertise to oversee complicated, rapidly changing and costly issues of governance in social and economic spheres.

Figure 1. Comparison of budget expenses on the Presidential Administration and the Federal Government of Russian Federation (as a percentage to the available resources).

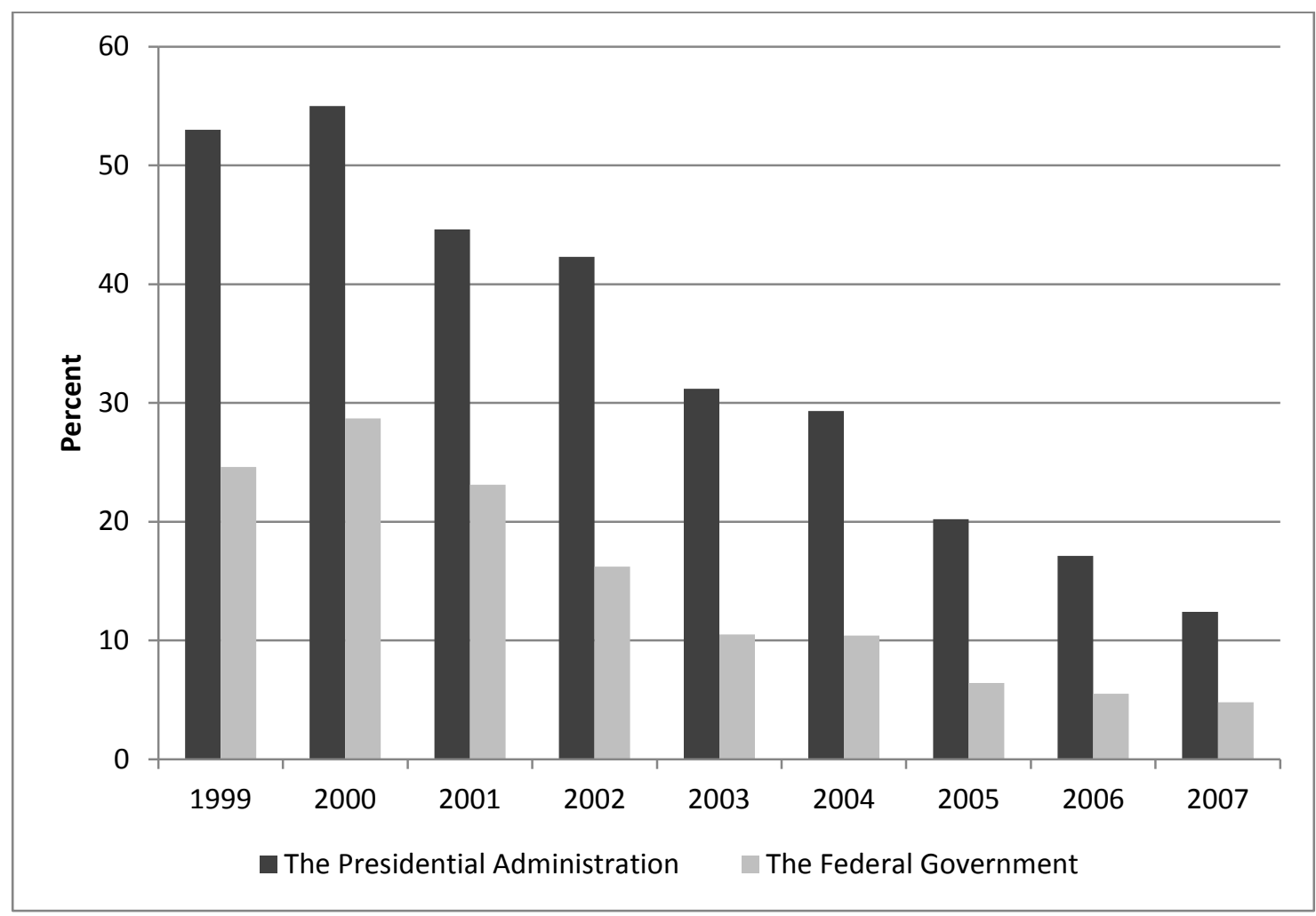

Figure 1 is prepared by the author using Budgets of the Russian Federation from years 1999 to $^{2007^{25}}$

The above mentioned arguments however, do not elucidate completely issues related to the existence of executive institutions of governance with partially overlapping

25 The data used in Figure 1 refers to budgetary expenses assigned to Department of Presidential Affairs of the Administration of the President of the Russian Federation (Article 303 of the list of major budget owners (rasporiaditel' biudgeta) in the Budget Classification). This article shows percentages out of total spending on the federal institutes of executive power. The data is taken from the annual budgets and uses earlier data is not presented in the table due to changes in presentation of sectoral allocation of budget spending prior to 1999. The gradual decline in proportion of spending on federal executive institutions signifies rapid growth of the budgetary funds. Yet the Figure reveals continuity of the trend when expenditures on the Presidential Administration nearly double expenditures on the Federal Government. 
authorities and functions. These issues primarily relate to the political significance of the presidential administration. The importance of this institution has been increasing constantly since the adoption of the Constitution and achieved its peak at the end of Vladimir Putin's first tenure. Although its major duty is explained as "support of president's activities" the Administration has been playing an important role in the political life of the country. The heads of the Administrations were influential politicians whose contribution to the political process in the country was assessed by many experts. Indeed it was also a quite large organisation.

A comparative analysis of budget expenditures on the President Administration and the Federal government shows the role of this institution in the Russian political process. Figure 1 presents the dynamic of budgetary spending on these two major federal institutions of executive power. It shows that budgetary expenses on the Presidential Administration were on average twice as much as the expenses on the Federal Government. The figure compares budgetary spending on each of the institution as proportion to the total spending on all federal state institutions and programs. The decline in proportions of spending on both institution reflects the trend of growth of the national economy in the first decade of the $21^{\text {st }}$ century. Increased budgetary revenues allowed financing to be extended to various projects under the aegis of the president. What is relevant for the topic discussed in this chapter is the fact that the political status of the presidential administration was has been affirmed by the financial support of this agency.

\section{Russian public administration in a historic and institutional perspectives}

The federative structure of the state also determined the existence of a three-layer system of executive institutions in Russia: 1) the federal government, 2) its regional 
bodies, and 3) regional governments. Although the Constitution and respective legislation established a hierarchy of institutions and divided responsibilities among the various layers, as well as prescribed the principles of coordination of activity, this complexity of institutions created issues which influenced the effectiveness of governance in the country in general.

Special attention must be paid to the structure and the internal political processes within the federal government. One of the most noticeable and significant events of the entire public administration reform was directly linked to this institution. On March 9, 2004, President Vladimir Putin issued a decree No. 314 that optimized the structure and relationships within the federal government, ipso facto signifying the beginning of the active phase of the reform of public administration in the country. The top-down approach in conducting the reform was, obviously, not due to a mere chance. The central government was itself a very sluggish and un-maneuverable organisation with a significant number of employees. Its institutional boundaries were also not clearly demarcated and functional ambiguity and often overlapping authority was normal practice.

According to the Constitution's regulations the government was moved under more direct presidential control. However it was not deprived of political functions. Involvement of the parliament for the approval and dismissal of the prime-minister also played a significant role. Thus the office of the prime-minister was able to gain 
independence from the president and potentially provoke "intra-executive conflicts." 26 The cases of the second Viktor Chernomyrdin's and, more strikingly, Yevgenii Primakov's governments, confirm the existence of this issue.

A strong prime-minister, who, in addition, bolsters parliamentary support, possesses a significant threat to the President's authority. During 1990s, the role of the Parliament in the political life of the country was quite significant. As the facts reveal, there were several attempts, (though all unsuccessful) to vote for no-confidence of the government, or even to impeach the president. In these conditions, there were four significant centres of power in the country: the President, the State Duma, the Government, and, to a lesser extent, regional leaders. Regardless of the constitutional supremacy of the presidential office, Boris Yeltsin was unable to enjoy it fully and had to seek compromises with other contesting political forces. In such conditions, the President fully exercised his control over the government. Counterbalancing the various interest groups within the government, the President was able to diminish the political role of the government and thus build space for political maneuvering.

However, these governmental reshuffles had important consequences for the effectiveness of the executive branch. The prevalence of political motivations in governmental appointments, in addition to the high frequency of these changes, determined the focus of the executives on short-term issues and policies. There was no pure ideological and conceptual concordance within government officials since the failure of the 'shock therapy' programme proposed by the Gaidar-leading team of liberals

${ }^{26}$ See: Oleh Protsyk (2006). "Intra-Executive Competition between President and Prime Minister: Patterns of Institutional Conflict and Cooperation under Semi-Presidentialism." Political Studies 54:2. pp. 219-244 
in the early 1990s. This situation resulted in constantly deteriorating macro-economic indicators and social indexes throughout the 1990s and eclipsed during the 1998 economic crisis in the country.

Since the adoption of the Constitution and the establishment of new principles of organizing the public administration, there have been twelve governments headed by nine different prime-ministers. Indeed there were eight governments before the formal beginning of the reform of public administration and adoption of a new structure of the executive branch in the country.

The first government of Viktor Chernomyrdin, which was appointed in 1992, survived the constitutional crisis and the following post-referendum political changes. Almost all cabinet members went through this transition. However in 7 out of 22 ministries, there were changes of the heads.

The second government of Viktor Chernomyrdin (1996-98) was established in accordance with the constitutional principle when the entire Cabinet resigns immediately after a newly elected president is inaugurated. ${ }^{27}$ Although Chernomyrdin was able to preserve his office, the resignation was not a mere formality. After the dramatic presidential elections, the very nature of top-level decision-making process had changed. The political influence of the major players in the Russian economy had increased drastically, helping Boris Yeltsin — quite unpopular in the beginning of electoral cycleto be re-elected by sponsoring his "Vote or loose" campaign, and giving him enormous media coverage. After the election, these business leaders demanded a payback on the

${ }^{27}$ Constitution of the Russian Federation. 1993. Article 116. 
help they provided. Therefore, in order to praise his supporters the President had to make some adjustments to the executive branch.

The tenure of the Cabinet of Viktor Chernomyrdin that worked for the two postelection years can be divided on two periods. The first period, which journalists neatly named 'semibankirschina', was marked by continued active participation of 'oligarchs' in political life. One of them, Vladimir Potanin was appointed deputy prime-minister. Another - Boris Berezovskii - was the executive secretary of the Security Council. Indeed the term 'semibankirschina' stems from the analysis of the current Russian political arena given by Boris Berezovskiy in his interview to the Financial Time journalists. Berezovskii revealed that the group of seven largest financial tycoons "meets weekly and works closely with Mr Chubais... [the] ailing President Yeltsin's chief of staff" and "[i]ts members portray themselves quite openly as the main force shaping Kremlin policy."28

The oligarchs' involvement into Russian politics had become evident even earlier, in 1995, when they orchestrated the "loans for shares" privatisation scheme, and acquired important state owned companies. As a result of these auctions were created large financial-industrial groups and vertically integrated (mainly oil) companies, that have since kept leading positions in the Russian economy. Acquiring these companies for prices which were significantly below their market values was only possible in a situation of cooperation between the state officials and the business tycoons. ${ }^{29}$ As Anatoliy

${ }^{28}$ Chrystia Freeland, John Thornhill, and Andrew Gowers (1996). "Moscow's group of seven." Financial Times. November 1.

${ }^{29}$ See: Sergey Stepashin (ed.) (2004). Analiz protsessov privatizatsii gosudarstvennoi sobstvennosti $v$ Rossiiskoi Federatsii za period 1993-2003 gody. Moscow: Olita. 
Chubais stated, this was a purely political decision. ${ }^{30}$ Liberal officials in the Cabinet were pursuing two major goals. First of all, by selling the state owned property to the newly created class of businessmen, they were seeking to diffuse the economic power of the old soviet nomenklatura that supported the communist party of Russia. Many important corporations were run by the so-called 'red directors' - old school managers who secured control over national industry after the collapse of the Soviet Union. They largely repudiated early liberal reforms and remained significant ties with the Communist Party on the one hand, and regional governors, especially from the so called 'red belt' of Russian regions ${ }^{31}$, on the other. These managers were portrayed as ineffective and needed to be replaced. Secondly, the grave economic situation and a permanent budget deficit on the eve of the electoral cycle were obvious threats; furthermore, any potential derangement in the payment of social obligations could have aggravating consequences for the ruling political elites. Thus, budgetary infusions were necessary, and the cash flow was achieved by means of these auctions.

The fact that the liberal wing of the government was able to conduct such policies, speaks for its political weight in the government. They also benefited from the unquestionable support of President Boris Yeltsin, whose political views must not be disregarded in the analysis of his manpower decisions. In fact, the early second government of Viktor Chermomyrdin was the logical successor of the pre-election one

\footnotetext{
${ }^{30}$ Arkady Ostrovsky. (2004). "Father to the Oligarchs - Anatoly Chubais is rich by Russian standards, but not as rich as the billionaires created by his privatisation reforms. The lurch into capitalism won him enemies but will history forgive him?" Financial Times, November 13.

${ }^{31}$ See Vladimir Kolosov and Rostislav Turovskii (1996) "Elektoral'naia karta soveremennoi Rossii: genesis, struktura, evolutsiia.” Polis. No.4 pp.33-47.
} 
and included significant amount of liberal-minded officials. Many ministers from the previous government kept their positions and the reshuffle affected only the top-tier of the government: positions of deputy prime-ministers.

The direct involvement of business leaders into the governmental decisionmaking process provoked internal tensions within the government. Conflicts mainly occurred between the premier Viktor Chernomyrdin and his deputy, Vladimir Potanin. Boris Yeltsin noted that Chernomyrdin was worrying that Potanin used his position in the government in order to create privileged conditions for his newly acquired enterprise Norilsk Nickel company. ${ }^{32}$ These tensions resulted in Potanin's resignation. However this resignation did not mean the loss of the reform wing in the cabinet, which enjoyed support from the president and his administration. Yeltsin continued the politics of balancing interests within the government, thus making it a weaker institution in comparison with the office of the President where factions were not tolerated at all. The result of these politics, in March 1996, was creation of the government of the so-called 'mladoreformatory' (young reformers). As Yeltsin himself recalled, he had wanted to "stir up" Chernomyrdin by introducing two liberal first deputy prime ministers: Anatoliy Chubais and Boris Nemtsov. ${ }^{33}$ These politicians were able to assemble a broad team of like-minded persons who were influential enough to counterbalance the traditional bureaucracy. This Yeltsin's cabinet reshuffle gave Russia "the strongest team of liberal reformers since late 1991.",34

${ }^{32}$ See: Boris Yeltsin (2000). Prezidentskii Marafon. Moscow: AST Publishing.

${ }^{33}$ Yeltsin (2000).Op.cit.

${ }^{34}$ Shevchenko. Op.cit. p. 125 
Regardless of strong presidential support for this government, some very unpopular decisions brought it to a critical point. Liberal ideology demanded strong reforms aimed at deregulation of economy and modernization of the social sphere. Especially unpopular were governmental budgetary initiatives and the second wave of privatisation. Fighting with unsecured budget spending under the unfolding 'insolvency crisis', Anatoliy Chubais, who was deemed responsible for the economic affairs in the government, called for a sequestration of the federal budget. Such a measure was perceived with hostility by the Duma's leftist majority. Furthermore, increasing tensions between various financial groups over privatization of state property and in particular the 'Svyazinvest' holding company, resulted in the so-called 'informational war of banks.' Liberal public officials, who were directly responsible for privatization - Anatoliy Chubais and Alfred Koch (Minister for State Property) were directly involved in the conflict. A notorious 'book scandal' over incomparably high honoraria for a book on privatisation were portrayed in the media as a direct indicator of corruption.

The president's decision on the resignation of Chernomyrdin's government was unexpected for the majority of population. Although, only the 'liberal ministers' of the government were under public criticism, Viktor Chernomyrdin's resignation could hardly be avoidable. Many experts and analysts post-factum speculated on the reasons why Viktor Chernomyrdin was resigned. Some said that he was acting as the "crown prince" and built significant independence from the President. ${ }^{35}$ Others assumed that he could not

\footnotetext{
${ }^{35}$ This opinion was cited by: Gordon Hann (1998) "From Chernomyrdin to Kirienko: the rise of the Nizhnii Novgorod group." Problems of Post-Communism. Vol. 45, No.5 pp.316
} 
distance himself from the 'young reformers' ${ }^{36}$ Yet there could be another hypothesis, which is that the President wanted to improve control over the government. Or, as Gordon Hann suggested, Yeltsin was "[1]ooking to cement his place in history as the "father of Russian democracy." ${ }^{37}$ If either (or may be a few) of these assumption were correct, Yeltsin needed a government capable of conducting radical reforms and, at the same time, being independent from any force or lobbying group except the office of President.

This idea is rather supported by Yeltsin's insistence on Sergei Kirienko's candidacy as the next prime-minister. Yeltsin portrayed his appointee as a 'technocrat' capable of conducting reforms with the highest efficiency, as he was lacking of any strong ideological background. By making another reshuffle in the government, Boris Yeltsin removed more than just a few liberals. Indeed the changes affected the conservative block in the government as well. As a counter measure to Chubais' resignation, a high-ranking representative of the law-enforcement bloc - deputy prime minister Anatoly Kulikov, was removed.

The government of Sergey Kirienko was quite different from the previous one in terms of its internal composition; however it maintained its major political values. First of all, it was the most institutionally compact government - totalling 58 different governmental organisations and only 22 ministries - the smallest numbers for the federal government so far. Although the top executives in the government were changed, the government itself lost a significant liberal ideological orientation, deeply intertwined with

\footnotetext{
${ }^{36}$ Iulia Shevchenko. Op.cit. p.125

${ }^{37}$ Hann. Op.cit. p.3
} 
the name of Anatoly Chubais, called the 'young reformers' government. The so-called "Nizhnii Novgorod clan" took advantage of this situation. Its representative, Boris Nemtsov, secured his position as deputy prime minister; and some other liberally minded politicians (or 'technocrats' as Yeltsin himself called them) like Oleg Sysuev were promoted to the leading positions in the government.

The government continued suffering from the same problems in economic and social spheres which it inherited from the second Chernomyrdin's cabinet. The set of the issues the Kirienko's government had to deal with was pretty much traditional for 1990s Russia. Remarkably however, there began mass social protests in the country. The most famous were demonstrations of mining workers who demanded full and prompt payment of their back pay. It may be assumed that the cabinet shuffle was 'cosmetic' and did not affect substantially the dispositions of major groups of interest. This cabinet was not shaken up by the intra-governmental conflicts. No open confrontation between the government and other political institutions, mainly the Duma and the presidential administration, were noticed at the time. Furthermore, the level of governmental dependence from big business did not diminish either. In order to deal with major issues in the social sphere and being able to maintain its regular duties, Sergey Kirienko needed the support of the business community. He proposed the creation of the Council for economic cooperation that would include ten top businessmen and ten public officials. ${ }^{38}$ Thus, necessity to maintain the functionality of the government and its direct vulnerability to external lobbyism, allowed avoiding internal conflicts. At the same time it is impossible to ignore the shortness of the cabinet's tenure, which was mainly due to

${ }^{38}$ See: Andrei Bagrov (1998). "Hudshee iz vozmozhnogo.” Kommersant. No.109(1512). 
the August 17 default in payments of state bonds and the subsequent financial and economic crisis. The government was made mainly responsible for the situation and was sacked by the President.

Changes in the nature of federal public administration began shortly after the economic crisis of 1998. Following the Duma's double rejection of Viktor Chernomyrdin's candidacy for the post of the prime-minister, president Yeltsin proposed to the office of Minister of Foreign Affairs, Evgenii Primakov. According to Boris Yeltsin's memoirs, he initially intended to return Viktor Chernomyrdin to the cabinet. His resignation earlier that year was presented as a misunderstanding. However, the left majority of the State Duma rejected his candidacy as un-approvable. Thus the president was looking for a trade-off, and hence was looking for a candidate who would satisfy the opposition. Such a candidate was Evgeniy Primakov - during a long career, he had worked in many different units of the government. He was approved in the first voting, receiving 317 votes (out of 450).

The composition of Yevgenii Primakov's government was quite different from earlier governments. The new prime-minister not only changed the composition of half the cabinet, but also appointed members of the opposition to the body as well. Such personalities as Yuri Maslyukov, Gennadii Khodyrev, Gennadii Kulik, and Vadim Gustov - were welcomed by the communist faction in the Duma. Experts outlined that Primakov's government, full of 'heavy-weight' and 'old school' public officials, was leaning towards the left. ${ }^{39}$

${ }^{39}$ Pekka Sutela (1999). "Russia: the state and future of the economy." BOFIT Online No. 4. pp. 1-14 
In crisis times the government was pretty much solidified internally. Additional support from the State Duma only increased tensions between the President and the Prime Minister. Remarkably, but the internal composition of the government, that some experts and president Yeltson himself called "the coalition government" to a greater extent determined the essence of economic measures undertaken by it. Apart from the experienced deputy prime ministers, Maslyukov and Kulik, Primakov insisted on the candidacy of Viktor Geraschenko as head of the Central Bank. Geraschenko replaced Sergey Dubinin who was sacked as a result of the August crisis. While the actions of the former head of the Central Bank were criticized by Primakov, the owners of the top Russian financial institutions however, insisted on keeping Dubinin in the office.

Regardless of its high efficiency, political stability and internal congruence, Primakov's government was dismissed by the President on May 12, 1999. Those actively involved in the political process at that time express different opinions on the reasons why the resignation took place. Regardless of these estimates this resignation was due, to some extent, to increasing support of Yevginii Primakov by the parliamentary opposition. Growing political weight and, thus, political independence of the prime-minister ultimately threatened the disposition of power in the presidential political system, when the agent (prime-minister) was no longer totally dependent upon the principal (president). With some rather substantial remarks, Primakov's resignation may be compared to that of Viktor Chernomyrdin's a year and a half earlier. However, the 'Primakov affair' stripped down the essence of political conflict that was put into the core of under-reformed public administration in Russia. Asking for Primakov's resignation was a very tough decision to be made by President Yeltsin, because, as a public opinion poll suggested at the time, it 
was negatively received by the public. ${ }^{40}$ However, it was politically important due to the specificity of the super-presidential constitutional arrangement of power in Russia. The institute of prime-minister appeared to be quite influential subject of the political process. Distancing himself from unpopular governing decisions, the President delegated significant powers to the office of the prime-minister. In situations when public support for the president goes declines, the prime-minister, with support of the legislative body, could be seen as an effective alternative to the president. "Parliamentary support is essential for the prime minister to claim authority over the executive branch of government. Intra-executive relations are critically affected by the nature and the level of parliamentary support that the prime minister enjoys." ${ }^{\text {41 }}$

Unlike Viktor Chernomyrdin, who after 1995 could rely only on one political party in the Duma (Our Home - Russia), Yevgenii Primakov's candidacy was approved by many factions. Moreover, he exercised wide public support. Indeed Primakov's activities as prime-minister were approved by 70 per cent of CPRF supporters. This was an expected outcome given the policies he was enacting. At the same time, quite

\footnotetext{
${ }^{40}$ On May 26, 1999 'Public Opinion Foundation' issued a review which stated that 81 per cent of respondents negatively reacted on the resignation of the Primakov's government. The data also showed that the public positively assessed the results of the primeminister's relatively short tenure. For more details refer: G. Kertman (1999) Smena Kabineta: Predvaritelnye Politicheskie Itogi. FOM |Online| [URL: http://bd.fom.ru/report/cat/pow_gov/government_primakov/o904901] (Accessed April 4, 2012).

${ }^{41}$ Oleh Protsyk (2006). "Intra-Executive Competition between President and Prime Minister: Patterns of Institutional Conflict and Cooperation under Semi-Presidentialism." Political Studies. Vol. 54, pp. 222.
} 
surprisingly, his statist approach gained support from more than 60 per cent of the liberal electorate. $^{42}$

The next prime-minister - Sergei Stepashin was easily approved by the Duma. Some say this was due to proper tactical moves undertaken by the President and his administration. Others argue that the Duma opposition did not pay attention to apparently unpromising candidate and concentrated on the upcoming Duma elections, which were due in around half a year. Finally, there was an idea cultivated by the media that the Kremlin is in an "agony", and was desperately searching for a candidate to become Yeltsin's successor. Regardless of all these opinions, Stepashin's government played an important function in eliminating the existing governmental coalition. Evgenii Primakov, his left-wing deputies Maslyukov and Kulik, as well as his other supporters within the Cabinet, were all dismissed. Sergei Stepashin's government tenured only for three months and, obviously, no internal composition had really affected its activity.

In these circumstances the first premiership of Vladimir Putin seems to be quite important. The short term Stepashin government eliminated the idea of a coalition cabinet, which might signify a trend of cooperation between president and the Duma. Indeed as a result of this, the latter lost any political influence over the government. Thus this led to the ascent to power of two bureaucratic groups within the executive branch.. The first was a united, pro-liberal and technocratic group of officials led by finance minister Mikhail Kasyanov. The other was represented by a group of military and lawenforcement officials, whose importance grew with the escalation of conflicts in the North Caucasus.

42 Ibid. 
The situation had not changed after the 2000 presidential elections. Vladimir Putin formed his first government by trying to balance different political interests. The government of Mikhail Kasyanov continued to be the arena for political bargaining between different economic and political cliques. The structure of these cliques, had, nevertheless, changed. Most experts agree that the first presidency of Vladimir Putin was marked by the rise of a bureaucratic group representing law-enforcement and military personnel. The group received the nickname 'siloviki'. It was opposed by those who could be named 'liberals', as they still proposed liberal measures in modernizing the economy and even the state. Finally, there was another, centrist and less ideological group of officials who were named 'technocrats'.

Some experts argued post-factum that Kasyanov's government was, in fact, the necessary step in the incremental decline of the old Yeltsin's clan. It was argued that during Vladimir Putin's first presidential term, major figures associated with the old political elites, such as Mikhail Kasyanov, Alexander Voloshin (Head of the Presidential Administration), and federal ministers Viktor Kalyuzhniy and Nikolai Aksyonenko, lost their positions in state organisations. ${ }^{43}$ Although such observation is evidently truthful, the exclusion of members of the 'old clan' does not seem to be important in the case of major political and economic decisions undertaken by the new government.

Relationships between the 'siloviki', the 'liberals' and 'technocrats' to a great extent, determined the flow of reforms in the country. These groups did not have clear and evident demarcations, either in terms of allocations of ministerial positions, or even

${ }^{43}$ See: Il'ia Bulavinov. (2003, November 10). "Koloda Rossiiskoi Federatsii." Kommersant-Vlast No. 44(547). 
in terms of ideology. The 'siloviki' group can be best explained as "an informal network of government officials and businessmen, led by the core group of Sechin, Ivanov, and Patrushev, who share similar political views, pursue a common policy agenda, and seek joint control over economic assets. ${ }^{44}$ Ian Bremmer and Samuel Charap outlined several ideological features that tie together members of this clan and allow them to expand their influence beyond their traditional 'zone of authority' in law-enforcement ministries and services. These values correspond with major paragraphs of the president's political program for rebuilding the country, which Vladimir Putin developed for the 2000 election campaign. 'Siloviki' share the president's views on the active role of the state in the social and economic life of the country. They believe that the state must exert control over key economic industries and, more importantly, over country's natural resources, as far as they belong to the whole nation, not few oligarchs. 'Siloviki' are recognized mainly by their past or present military background, however this is not an exclusive criterion. Bremmer and Charap mention some of members of the group with totally civilian backgrounds. ${ }^{45}$ Sergey Bogdanchikov for instance, was then the head of the state owned oil company "Rosneft", and did not have a military background. On the other hand, some officials with secret service or military experience, such as Sergey Stepashin (head of the Accountant Chamber) or Sergey Shoigu (Minister of Defense) are not considered members of the 'siloviki' clan. Thus, it is more correct to mention personal connections with Putin and his circle and ideological like-mindedness, rather than professional occupation as factors of membership in the group.

\footnotetext{
${ }^{44}$ Ian Bremmer and Samuel Charap. (2006-07). “The Siloviki in Putin's Russia: Who They Are and What They Want." The Washington Quarterly, Vol.30:1, pp. 83-92. ${ }^{45}$ Ibid.
} 
This group had approximately ten leading positions in the government, and had partial control over several more. It is important to mention that the rapid and impressive ascend of the group was mainly due to close and often personal connections of its members to Vladimir Putin. Although, in Kasyanov's government, their presence in the top tier (heads of ministries and services) of the bureaucratic hierarchy was not overwhelming, they were able to occupy many positions in the second and third tiers. Research by Olga Kryshtanovskaya and Stephen White shows that "among all deputy ministers appointed between 2000 and 2003, more than a third (35 percent) had a military or security background." 46 Authors stress that these officials were appointed in economic and social ministries (Economic Development, Industry, Communications, Justice, Transport and many others). Overall, 'siloviki' accounted for nearly half (45 percent) of all deputy ministerial appointments in the civilian departments and ministries of the federal government.

The other group of liberal ministers mainly occupied the economic and social sectors in the government. Its ideological position and political agenda were somewhat different from those of the 'siloviki' group. It was headed by the ministers of Economy and Trade - German Gref, and Finance - Alexey Kudrin. These two ministries were initiators of many liberal reforms in the early years of Putin's first presidential tenure. Among the most prominent members of this group could be mentioned a few other public officials. The topology of their positions within the Russian statehood varied from minister's positions in the government (like minister for Health Care Mikhail Zurabov,

${ }^{46}$ Olga Kryshtanovskaya and Stephen White. (2003) "Putin's Militocracy." Post-Soviet Affairs, 19:4, pp. 289-306. 
and minister for education Alexander Fursenko) to presidential administration (Andrey Illarionov, former advisor to president Putin) and even state-owned enterprises (like Anatoly Chubais, president of the RAO UES).

The third cluster of officialdom in the early 2000s consisted of the so-called 'technocrats'. Their major distinction from the two other groups is a lack of ideological constraints and a focus on the efficiency and productivity of their work. Therefore, that allows them to "operate equally well in the interests of authoritarianism or oligarchy" ${ }^{47}$ as well as to participate and promote quite liberal reforms. Among the technocrats, experts mark out such ministers as Ilya Klebanov (deputy prime-minister), Dmitriy Kozak, or Boris Alyoshin.

This three-cluster classification is quite conditional. Some experts suggest that no distinctions should be made between the liberal and technocratic groups. ${ }^{48}$ Others prefer observing the government from a more classical point of view as having the conservative, centrist and liberal wings. There also exists another taxonomy, which is based on the geographic principle. Such classification sees the Kasyanov's government being comprised of two major bureaucratic groups: the 'Muscovites' and the 'Petersburgers'. All these classifications are not mutually exclusive as they represent the composition of the government from different perspectives.

Decisions made by Kasyanov's government fully reflect the disposition and strength of the political groups within the government. Each group was able to promulgate reforms in the spheres of their major interests. The 'siloviki' group however,

${ }^{47}$ See: Liliya Shvetsova (2007). Russia: Lost in Transition: The Yeltsin and Putin Legacies. Washington: Carnegie endowment., p. 115

${ }^{48}$ Ibid. 
seemed to be more efficient, as far as it was able to achieve (or at least substantially move forward in achieving) results that suited their perceptions. With respect to political system, the 'siloviki' were successful in diminishing the political influence of regions and regaining control over law-enforcement structures at the regional level. Many other political reforms, aimed at strengthening the vertical of power and the role of the central administration, were launched under their direct control. The reform of the Armed Forces of the Russian Federation, that reorganized the structure of the military, improved the country's defensive capacity. The Ministry of Internal Affairs reform, which was launched in 2001, substantially reorganized the structure of the ministry and allowed it to escaping some of legacies left over from the 1990s. The reform also contributed to the improvement of manageability and vertical subordination within the ministry. Furthermore, as it followed from the ideology of the 'siloviki', they were able to address their concerns regarding the condition of the state and economy through a series of reforms. They were able to centralize and significantly improve performance of the strategic sectors of the economy, such as military production and trade. Through a series of amalgamations of formally independent industrial corporations and the creation, on their basis, of a group of military-industrial giants (such as 'Almaz-Antei' Corporation, or JSC United Aircraft Corporation) the state improved its control in the sphere of military supply and arms modernization.

At the same time, 'liberals' were granted freedom to design and promote reforms in other sectors of economy and public life. Parallel to the building the 'vertical of power' in the country, there were launched reforms based on the rather opposite ideology of decentralization. One of the most striking examples was the reform of the Unified Energy 
System (RAO UES) that was launched in 2001. In 2002 a reform of the pension system began. Indeed many innovations were proposed in the sphere of economic and finance. Despite open public discontent, the 'liberals' were able to persuade the president to accomplish a very radical reform of monetization of social benefits. All these reforms were aimed at a further introduction of market principles into the national economy, as well as the social sphere. Programs of these reforms were a result of joint work of the corresponding ministries, whose leaders comprised the liberal wing in the government.

Regardless of the quite substantial ideological differences, which existed between the intra-governmental groups, it seems like they were getting along together pretty well. Such effectiveness was, perhaps, the result of more or less clear demarcation of zones of interest and open adherence to the political course proposed by the president. Yet the last composition of the cabinet prior to the reform of public administration inherited most of the flaws of the system of governance that were formed in first post-Soviet decade. More strikingly these flaws could be observed in the structural organization of the executive body. All pre-reform cabinet reshuffles were not aimed at solving the most significant issues of the post-Soviet system of government, most critically the problem of differentiation of duties, notably at the federal level between various ministries, committees and agencies; so also at the regional level, between the federal and regional executive authorities. Instead, as the provided review argues, most changes in the cabinet reflected the political situation and current disposition of political forces that existed in Russia in the relevant time period. Seats in the cabinet were important bargaining chips for the major political actors. The choice of the prime-minister and top-level public officials, were the results of negotiations between the President and the State Duma. 
Altogether we witness the growth of the political weight of the presidential administration, which constitutional duties allowed it to de-facto became one of the most influential organizations of the state and conduct to some extend independent politics.

\section{The system of public service in post-Soviet Russia.}

The public service of post-Soviet Russia represented another issue for building the system of effective governance in the country. Despite the significant transformations that occurred in this sphere during the first post-Soviet decade, the bureaucratic corpus still had many flaws. An ineffective civil service was among the hindrances, as mentioned by President Putin that hampered the efficient socio-economic development of the country. The changes to the public service, which occurred in the first post-Soviet decade, were dominated by two major issues: the first one was overcoming legacies of the Soviet model of bureaucracy; the second one was struggling with consequences of the country-wide economic downfall and subsequent impoverishment of the bureaucratic class.

It is common among researchers, when analyzing the reasons for the collapse of the Soviet system, to outline, among the major factors, the very nature of the administrative-command system of governance and define "the major problems of Soviet society as a function of hyper-bureaucratic growth unchecked by democratic constraint. ${ }^{, 49}$ These scholars argue that the Soviet bureaucracy penetrated and dominated every sphere of public life, constructing the agenda and providing regulations and control. As such a system would demand a very large administrative apparatus, experts

${ }^{49}$ Robert J. Brym and Vladimir Gimpelson (2004). "The Size, Composition and Dynamics of the Russian State Bureaucracy in the 1990s." Slavic Review, Vol. 63 No.1. p. 90 
argue that the Soviet bureaucracy was enormous. However is rather difficult to compare the quantitative characteristics of public services in the late Soviet and early post-Soviet states to those of, say, the major OECD countries. Yet it still remains a very popular approach not only among the journalists but also among academicians.

The difficulties in drawing these comparisons, are embedded in the nature of the Soviet political and administrative-command systems, and were generally explained in the previous chapter of this dissertation. Firstly, the socialist doctrine implies that the private sector is virtually non-existent in the national economy. Therefore, the total majority of the workforce in such countries are state employees. This makes it impossible to distinguish the public sector from the private one, as it is commonly done in organizational statistics of many countries. ${ }^{50}$ Another issue, concerns the solely governmental part of public sector. In the Soviet times this sector was heavily politicized. It consisted of public and party officials who were deeply intertwined and hardly distinguishable in functional terms. The situation led to constructing the unique social stratum named 'nomenklatura'. However, as it was defined by Mikhail Voslenskiy, the nomenklatura itself could not be compared to the public governance sector of many developed countries. The nomenklatura includes categories (such as directors of state corporations) pertinent to the "government business enterprise" sector of the OECD

\footnotetext{
${ }^{50}$ In its documentation, the International Labour Office defined 'public sector' as: "all market or non-market activities which at each institutional level are controlled and mainly financed by public authority" and it is "composed of a general government sector and a public corporation sector." For more detail refer to: Messaoud Hammouya (1999) Statistics on Public Sector Employment: Methodology, Structures and Trends. Geneva: ILO |online| (URL:

http://www.ilo.org/public/english/bureau/stat/download/wp pse_e.pdf). (Accessed May 20, 2012).
} 
countries. At the same time, lower levels of public officials who constitute the quantitative majority of the 'governmental' component of public sector, are excluded from the nomenklatura. Therefore, the nomenklatura cannot be considered a good equivalent to the public sector employees in countries with a market economy. A classical comparison of public servants is also not applicable in this case, because many of those who really acted as bureaucrats were not public servants, but rather party functionaries. A good example here would be position of the secretary of regional branch of the Communist Party. This position was de-facto equivalent to the gubernatorial post in the contemporary Russian system of public administration but it was considered as a party post and not an administrative one. In addition, as Vladimir Gimpelson argues, there were methodological issues with the data on Soviet and early post-Soviet bureaucracy, which complicated comparative analysis. Russian statistical agencies issued reports on the basis of designated public administration statement forms, which included "not only officials in state posts but also the large army of service workers" who were not civil servants themselves. ${ }^{51}$

Likewise, comparing the public sector in Russia with that of the OECD countries during the early 1990s is challenging. Nevertheless several attempts were made. Thus, according to research conducted by the International Labor Office, the Russian public sector accounted for $37.6 \%$ of the total workforce in 1995 . According to their study, the Russian public sector (which included both government and public enterprise components) was significantly larger than those in world leading economies, especially

${ }^{51}$ Vladimir Gimpelson (2002). "Chislennost' i sostav rossiiskoi biurokratii." Voprosy Ekonomiki. No. 11 pp. 91-107. 
USA, UK, and Canada, that significantly shrank their civil services in the 1980s. Yet the quantity of public employees in Russia is quite comparable with those in the North European countries that adhered to the so-called 'Scandinavian model of government'. Finally, quantitative indicators of the public sector in Russia were within the general trend established by the group of post-Soviet countries in transition.

Figure 2. Public sector to the total workforce ratio (in $\%)^{52}$

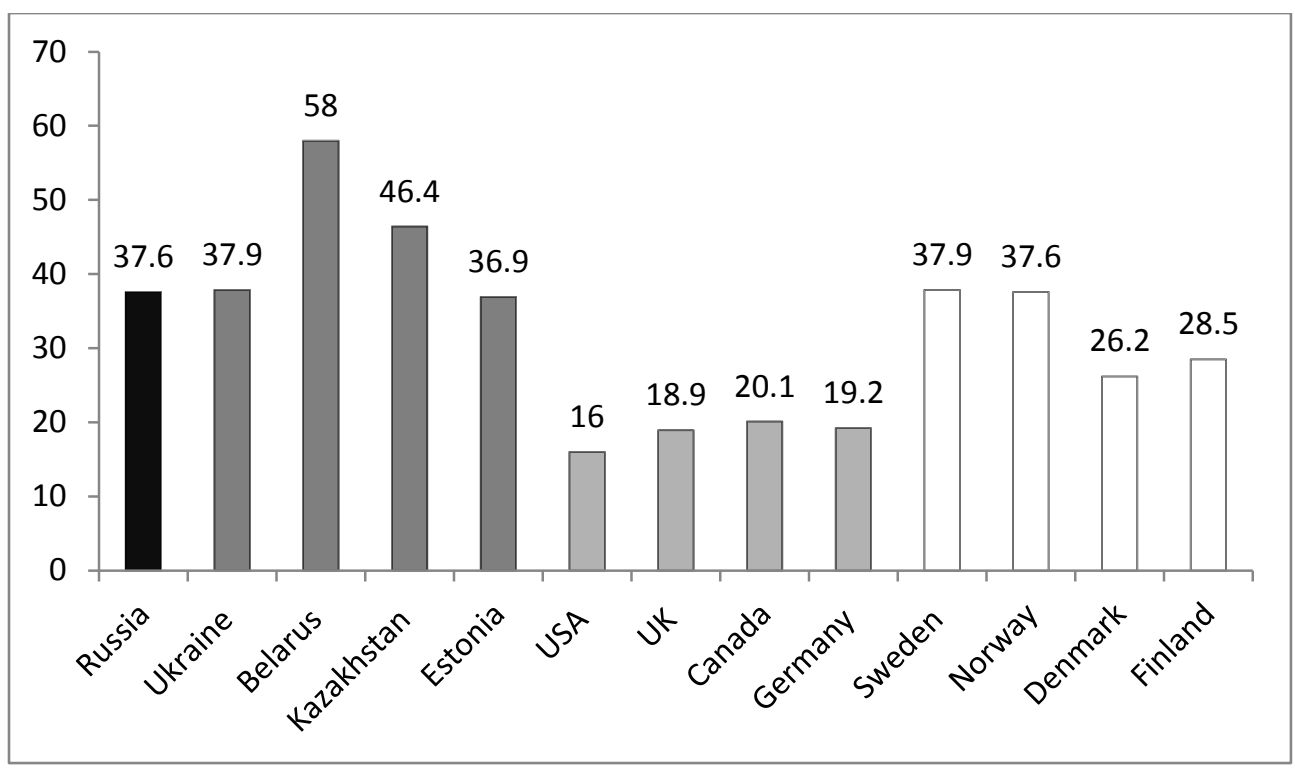

This statistic questions the validity of the argument that the size of public sector was the dominating factor leading to its inefficiency and functional drawbacks. The argument becomes even less evident when researchers turn to the particular cluster of the public sector - its 'bureaucratic' component (or, in other words, employees, working for the institutions of government). Figure 3 shows the dynamic of development of the Russian governmental sector.

${ }^{52}$ The chart was prepared by the author on the basis of ILO data published in: Messaoud Hammouya (1999) Statistics on Public Sector Employment: Methodology, Structures and Trends. Geneva: ILO |online| (URL http://www.ilo.org/public/english/bureau/stat/download/wp_pse_e.pdf). (Accessed May 20, 2012). 
Figure 3. Percentage of the 'government' sector to the total workforce in Russia in $1990 \mathrm{~s}^{53}$

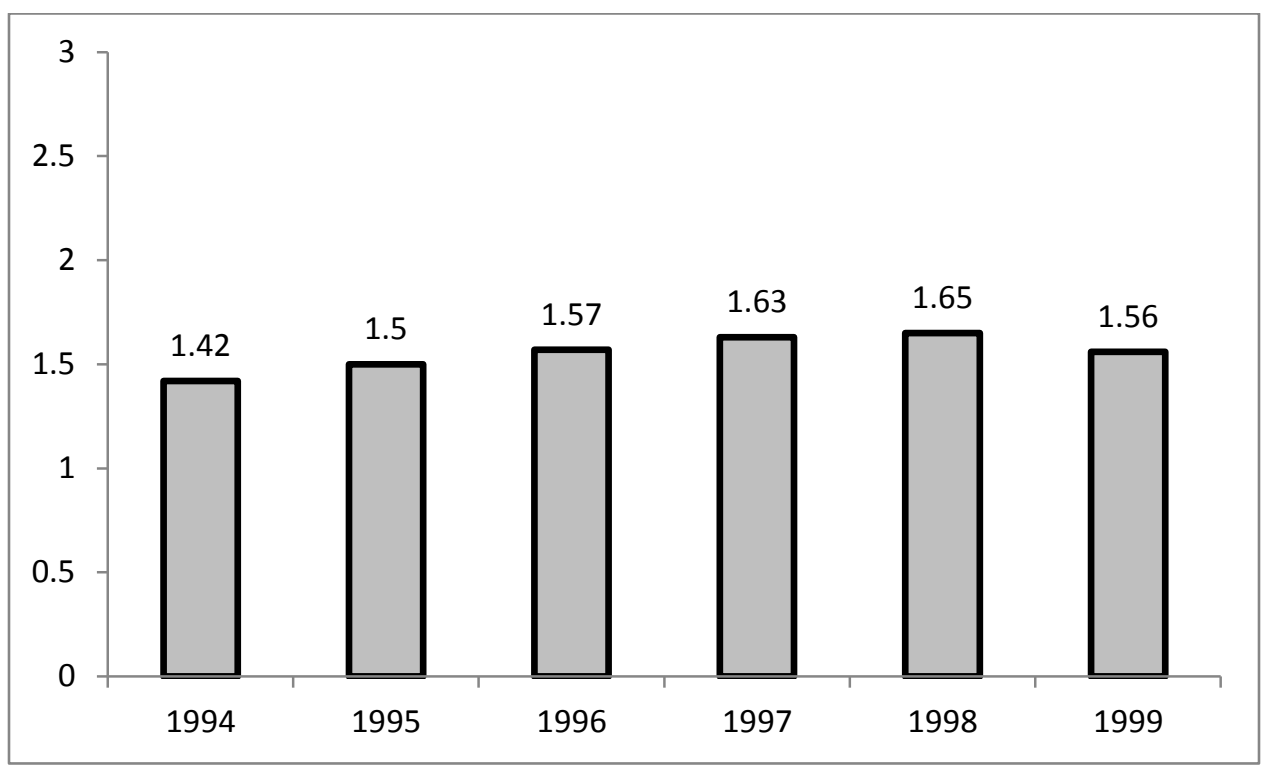

Regardless of complications with the available data, it becomes evident that the Russian government sector is significantly smaller than those in the OECD countries. For example, in countries where the ideology of "shrinking the government" was very popular - USA, United Kingdom and Canada - employment in the so-called "limited" public sector (similar concept to the one used in Russia) accounted for approximately 7 , 3.5 and 7.5 percent of total employment respectively. In countries that are considered most successful in reforming their civil services - Australia and New Zealand - the estimates are 4.5 and 3.5 percent respectively. ${ }^{54}$ These are much higher ratios than in

${ }^{53}$ The Figure is assembled by author on the basis of: Trud i zaniatost' $v$ Rossii-2011. Federal Service for state statistics. The 'governance' sector includes only those employees who work in the administrative units of all levels and may be considered bureaucrats in the classical connotation.

${ }^{54}$ The data for USA, UK and Canada is derived from the official statistics provided by the statistical agencies of the respective nations. The data for Australia and New Zealand is calculated by author on the basis of 2006 United Nations' Public Administration Country Profile snapshop. Only government employees of all levels of government are included in this statistic. Employees from the public sector (like school teachers, medical personnel etc. are not accounted for in this analysis). 
Russia (shown in Figure 3). At the same time, it should be mentioned that direct governments' involvement into the economic life of these countries by means of owning and managing economic enterprises is significantly lower than in Russia. Thus, as Brym and Gimpelson wittingly argue: "Russia's state bureaucracy is problematic in many ways, but size itself is not one of them.",55

Therefore, if major criticism of the early post-Soviet Russian public administration, based on its size, is ruled out, the questions regarding other Soviet legacies remained unanswered. These questions dealt with the legal foundations of the early post-Soviet bureaucracy in Russia, as well as with its code of conduct and ethics. Some researchers argue that, with the disappearance of the administrative-command system and control from the Communist Party, the bureaucratic apparatus of Russia was able to take control over major administrative processes. ${ }^{56}$ This apparatus was the complete successor of its Soviet predecessor in all but ideological accounts. It was an organization with its own genuine corporative style and administrative habits. One of its crucial features was lack of control from the society and, thus, orientation of lower level bureaucrats to the interests and goals of their patrons. In view of progressively thinking reformers, this bureaucratic class was particularly responsible for the collapse of the Soviet system; and thus it was able to rebuild itself in the new one, preserving the very

\footnotetext{
${ }^{55}$ Robert J. Brym and Vladimir Gimpelson. (2004) Op. Cit., p.101.

${ }^{56}$ Alexander Obolonskii (ed.) (2009) Gosudarstvennaia sluzhba: kompleksnyi podhod. Moscow
} 
same foundations. ${ }^{57}$ Without political control from the top this class was literally given free reign.

The situation was complicated by a severe economic downturn, increased inflation in the early 1990 s, and budgetary scantiness, which reduced away the previous well-being of public officials, and shattered the socio-economic basis of civil service. Lower level bureaucrats were among those who suffered most from these new economic realities. Such a situation could not improve their support of the course of rapid economic reforms proposed by the new political elite. In addition, this made public work less prestigious than jobs in the private sector. This trend continued for the first post-Soviet decade and thus led to the deterioration of the quality of personnel.

These difficulties demanded immediate responses from the ruling political elites. A systematic analysis of these responses allows outlining three major stages in developing of post-Soviet civil service prior to the beginning of the current reform. These three stages lasted for about a decade.

Some researchers argue that shortly after the dissolution of the Soviet Union one of the top priorities for the Russian political administration in the sphere of state building was to reshape the quite large cohort of civil workers and make them attuned to the new realities of the market economy. ${ }^{58}$ This issue was considered the top priority of the socalled first period of reforms of the public sector in Russia. The period was marked by work of the Russian agency for government cadres, Roskadry. This agency was active for

${ }^{57}$ See for example: Yegor Gaidar (1997). Gosudarstvo i evolutsiia. Saint-Petersburg: Norma.

${ }^{58}$ Tatiana Zaitseva (ed.) (2003) Reforma gosudarstvennoisluzhby Rossii: istoriia popytok reformirovaniia s 1992 po 2000 god. Mosow: Ves’ Mir. pp. 25-39. 
almost two and a half years and addressed a wide variety of issues that early post-Soviet officialdom was facing at that time.

Progressively thinking experts and politicians who comprised the close Yeltsin inner circle were concerned about overcoming 'Soviet legacies' in functioning of the state apparatus. Their major argument stated that some influential cliques of public officials, especially at the regional level and who used to be at the core of the Soviet nomenklatura, presented an obvious threat to the flow of democratic transformations. Conservatively oriented officials, who remained in the offices after the events of the Autumn of 1991, were capable of introducing delays or even boycotting some of the decisions made by federal authorities. These considerations necessitated that the first period of civil service reform was almost entirely concentrated on personnel retraining.

The federal agency Roskadry was established on November 23, 1991. Its goals, list of responsibilities, and even internal structure were the result of a meticulous concurrence of interests and positions of many influential political forces of that time. Its proposed duties (among others) included improvement of the normative foundations of the post-Soviet state apparatus, streamlining human resource management by establishing categories of public servants, as well as creating separate rules and procedures for advancement of their functioning, research and development and other scientific work in the sphere of public administration. At the same time, as the first agency director Hasmagomet Bekov outlined, initially Roskadry mainly concentrated on reshaping the inherited system of education and retraining public officials. ${ }^{59}$ It was decided that the

${ }^{59}$ Hasmagomet Bekov provides a detailed chronological review of activities of the Agency in the first part of the book: Tatiana Zaitseva (ed.) (2003) Reforma 
system of former Higher Party Schools had to be transformed into a network of regional Academies of Public Service. Ideally the objectives of these institutions should not only be confined solely to educational tasks; rather they must conduct research and provide consultancy in the sphere of public service.

One of the crucial features of the ideology, as well as the modus operandi, of Roskadry, was total adherence of its top executives to the principle that public human resource management is entirely the prerogative of the President. More likely, such a posture was among the major reasons why the work of the agency was considered unsuccessful, even by its own employees. Overall, the agency rolled out a full variety of projects in the field of civil service: from the creation of regulatory legislation to international research activities. However, most of this work did not result in any productive outcome. Experts believed this was mainly because of the insufficiency of political will of top layer of public officials. In addition, those who were accustomed with Roskadry activities, believed that lack of knowledge and experience, as well as some underestimation of the subject and object of the reform, also contributed to the misfortune of the organisation.

Indeed, despite some organisational efforts, Roskadry was not able to accomplish preparation of the final draft of the conception of public service in Russia and other related legislation. One of the reasons was the lack of agreement regarding ideological fundamentals of the new post-Soviet public service. However, despite such a major failure, it should be mentioned that Roskadry officials prepared a rather comprehensive

gosudarstvennoi sluzhby Rossii: istoriia popytok reformirovaniia s 1992 po 2000 god. Mosow: Ves Mir. 
program of reform, as well as a research and education agenda. Internal and guest experts performed substantial groundwork in order to develop the conceptual framework, as well as the consistent methodology of the reform process. In the prepared documents, Roskadry experts suggested establishing a five-tier hierarchical structure of Russian officialdom. Such a classification system was imperative in order to develop distinctive strategies of reform for groups of officials that differ not only hierarchically but also functionally. These five categories of public officials were: 1) the political nomenklatura of the President, 2) the administrative nomenklatura of the President; 3) rank-and-file bureaucrats; 4) highly experienced professionals; and 5) 'cadre nucleus of the market economy ${ }^{60}$ - the main body of average public servants, who were directly involved in providing administrative and governmental services to the population. Each category demanded distinctive approaches in the reformation process.

The first months of Russian independence were marked by widespread confusion in legal and regulatory spheres of public administration. The latter urgently needed to make a radical shift from Soviet nomenclatorial civil service to a system based on meritocratic and/or market principles. Although top executives from Roskadry and the Administration of the President recognized this issue, no immediate measures followed. Hence, for the first four years after independence, public service legislation was not renewed. Such terms as civil (state, public) service and civil (state, public) servants were not officially defined until the adoption of the law "On the bases of public service" in

${ }^{60}$ Hasmagomet Bekov and K.M. Skobeev (2003) "Harakteristika politicheskoi, ekonomicheskoi i sotsial'noi situacii, kotoraia sposobstvovala startu reform 1992-1993." In Tatiana Zaitseva (ed.) Reforma Gosudarstvennoi Sluzhby Rossii. Istoriia popytok reformirovaniia s 1992 po 2000 god. Moscow: Ves' Mir., pp.32-33. 
1995. In addition to other obstacles, such as the resistance of officials to innovations, this lack of judicial clarity significantly hindered the development of the former Soviet bureaucratic apparatus.

The activities of the Agency in the educational sphere can be considered satisfactory. Shortly after its creation, Roskadry was able to transform the old system of the preparation of cadres for public service (known as higher party schools) into an organized regional network of academies of public service. In a very compressed period of time specialists of the agency were able to develop a unified educational conception, introduce and certify a novel academic discipline (for Russia) - public administration studies. Many universities, institutes and colleges including the top ones (like Moscow State University) took advantage of this new program and created relevant faculties and departments. In addition to this the agency provided special retraining and personal advancement programs aimed at improving professional skills of public officials. Thus, in organisational terms, the Roskadry was successful in providing venues for preparing experienced professionals for the central and regional public administration.

If the infrastructural aspect of education had not raised concerns among observers, its functional and substantial characteristics did. There remained unresolved (or at least unfinished) issues of providing educational programs, which would address the specificity of the Russian public administration, as well as international experience, adapted to national realities. Syllabi of these courses, were in many cases loanworded from its foreign counterparts. The lack of authentic disciplines and the adoption of major methodological principles in studying public administration was an important factor in the preparation of new workforce of public organizations. 
Roskadry established a wide network of international contacts with similar agencies. Experts from France, Germany, the United Kingdom, Canada, and the European Union participated in sharing their expertise on proposed legislature, educational programs and various other projects. While in general, such openness of Russian agency officials was recognised as a very positive gesture, some of their decisions were considered unusual. In particular, Alexander Obolonskiy was perplexed by the active and broad communications of Roskadry officials with their French colleagues. He considered France as an improper example for imitation, due to the fact that the highly centralized French public service had already become outdated at the time. Other experts however, justified the inclusion of France into the pool of countries for expertise. Their arguments stemmed from the conclusion that the experience of a country that had already begun reforming its highly centralized bureaucratic system would be beneficial to the Russian case.

International experts participated in the evaluation of the proposed conception of the reform of public service. They supported the idea of Roskadry specialists to put the principle of the separation of political, administrative, and technical functions at the core of the definition of public service. ${ }^{61}$ At the same time, international experts criticised the idea of restoration of a hierarchically rigid structure of bureaucratic ranks. The proposed classification was spiritually identical to the system introduced by Emperor Peter I in 1722 in his Table of Ranks - a nomenklatural list of civil, military and courtier titles. According to many experts, both Russian and international, such stratification, in addition to civil jobs ranks, was considered unnecessary and even pernicious, as it was improving

\footnotetext{
${ }^{61}$ Ibid. p.70
} 
closeness and factionalism among public servants - and, as result, propagating the deterioration of the quality of the public service. However, regardless of such estimates this norm found itself in the legal documents adopted after liquidation of the agency.

As previously mentioned, Roskadry was disbanded in 1994 after two and a half years of work, despite its wide, multifaceted, and long-term strategic activities agenda. This decision was mainly influenced by the complicated political situation in the country. The agency's senior personnel actively supported the idea of the president's dominance in the sphere of public sector human resource management. This position significantly narrowed the spectre of supporters of the agency to Yeltsin's inner circle. Obviously, unequivocal support of the president removed the Supreme Soviet from the list of organizations that could express support for the reforms, as proposed by the agency. Even within the executive wing however, there was no unanimity. Among the president's closest allies there were politicians who looked with caution at the reforms proposed by Roskadry officials and experts. In addition, in response to the disastrous consequences of rapid economic reforms of 1991-92 and the loss of popular support by the group of radical reformers, in order to maintain functionality of the government, Boris Yeltsin had to promote the group of moderately conservative public officials led by Viktor Chernomyrdin, who was thus appointed to the prime-minister's position. After such reinforcement, this political group became a more active player on the political arena; issues of development of the public administration were thus included in its sphere of interest. Executives of Roskadry adhered to the ideology of radical reforms and in reverse, they were supported by the liberal wing in the government, headed by Yegor Gaidar and Gennadiy Burbulis. This inevitably resulted in tensions with the conservative 
wing, and willingness of the latter to promote an alternative plan for modernization of the state apparatus. As it was stated elsewhere, the Chernomyrdin group made several attempts to reduce involvement of Roskadry in the process of modernization of the postSoviet officialdom in Russia. ${ }^{62}$ For a short period, there were two alternative centres that worked on the design of the reform of public service: one was in Roskadry and the other - was in the Government's Apparatus. This 'diarchy' was resolved on December 23, 1993, when the President issued a decree No. 2267 "On the regulations of the federal state service", which was based on the draft prepared by the Apparatus.

Dissolution of the Roskadry agency symbolized the collapse of the liberal reform agenda in the sphere of civil service. Politicians who personified the project of radical reforms did not enlist enough supporters among public officials. Some experts even suggested that the reformers had never gained control over the state apparatus. Instead, "as it has become clear, nomenklatura accepted only a limited number of 'newcomers'..., and admission was approved by the old nomenklatura." ${ }^{, 63}$

By all accounts the first transitional period of transformation of the public service in post-Soviet Russia did not achieve the goals proposed by Roskadry experts. It actually ended in 1995 when the law No. 119-FZ "On the fundamentals of state service" was finally adopted. Altogether with presidential decrees No. 33 (January 1995) and No. 1574 (December 1995) "On the register of state jobs", these documents formed the legal framework for the new system of public service in the country. Experts outline the significance of the very fact of adoption of this legislation, stressing at the same time the

${ }^{62}$ Ibid., pp.59-64.

${ }^{63}$ Alexander Obolonskii (1996) "Postsovetskoe chinovnichestvo: kvazibiurokraticheskii praviaschii klass." Obshchestvennye nauki i sovremennost'. No.5 p.7 
fact that overall, the first period was rather unsuccessful. ${ }^{64}$ Regardless of the general trend on the deterioration of the quality of public administration in the country, these legal documents were positive steps in building Russia's civil service. Indeed the law established the foundation of the system of public work. It provided a clear and concise definition of a civil servant which outlined his/her major characteristics. The law also established a thorough classification and categorization of governmental jobs.

The law furthermore established a thoroughly defined nomenclature of state positions. First of all, it set up three categories of state positions: 'A', 'B' and 'C' (however, named after first three letters of the Russian alphabet); and only second and third categories were referred to civil service, whereas category ' $A$ ' referred to as so called 'constitutional' positions. The civil service was defined as a "professional activity for enforcing regulations of government agencies." ${ }^{25}$ Thus, the law implicitly differentiated the political and administrative functions excluding group ' $\mathrm{A}$ ' positions, from the register of civil service jobs. ${ }^{66}$ Secondly, besides the functional three category classification, the law introduced a 5-level hierarchy of state jobs, where Group 1 included the lowest positions and group 5 included the highest ones. Hence Russian officialdom received its exact structure of state positions.

Yet the law adopted the controversial principle of ranking public service titles, similar to those that existed in imperial Russia since 1722. As it was postulated, the

${ }^{64}$ Alexander Obolonskii (2009) Gosudarstvennaia sluzhba: kompleksnyi podhod. Moscow: Delo. Chapter 5., p.263

${ }^{65}$ Law No. 119-FZ "Ob osnovakh gosudarstvennoi sluzhby Rossiiskoi Federatsii” from June 31, 1995. Article 2.1

${ }^{66}$ Top public officials, such as president, prime-minister, speakers of the federal and regional legislative bodies, judges, deputies of the federal and regional parliaments and ministers, both, federal and regional are mentioned in in this law under Group 'A' . 
"qualification ranks of public officials indicate appropriateness of the level of professional expertise of public official to qualifying standards, relevant to the state positions of respective groups." ${ }^{67}$ The established ranks were: actual state councillor, state councillor, councillor of the Russian Federation, councillor of state service and referent of state service. Each rank consists of three classes. Thus overall, fifteen hierarchically ranged ranks were introduced. Although the law did not make this system mandatory (the law speaks of the possibility of giving a rank to a public official), it nevertheless was a step aside from the modern type bureaucracy. Qualification ranks increased dependence of public servants and, therefore their loyalty, to their superiors. Such an idea undermines the very principle of modern public administration as an institution that provides state services to the public. In the case of Russia it only complicated the process of transforming the ethos of public service from the nomenklatural principle of 'serving to the principal' to the merit based idea of 'service to the people'.

At the same time the law included a few quite progressive ideas. It ensured that professionalism was the major criterion for filling positions in the civil service. It also established education and qualification standards for applicants demanding specialised higher education for all but junior governmental positions. Examination and certification procedures have also been made pertinent to the appointment process. Overall, the adoption of a new law that determined the fundamentals and legal framework for ongoing modernization of the public service was definitely an advantageous move. However the

${ }^{67}$ Law No. 119-FZ “Ob osnovakh gosudarstvennoi sluzhby Rossiiskoi Federatsii” from June 31, 1995. Article 7.1 
law itself was pretty much written in the interest of the bureaucratic corporation. It did not become the driving force for evident qualitative changes in the Russian public service. Economic hardships even further complicated the situation.

The reform of public administration and civil service require constant impetus and control from either the ruling political elites or civil society. However civil society in the country had not been developed to a considerable level to pursue affirmative actions. The devastating economic condition of the first half of 1990s was another factor that led citizens to develop strategies of personal survival that even today retain topicality and to some extent keep defining the political process in Russia. Governing elites, on the other hand, were more concentrated on internal conflicts (as in case of the 1993 political crisis), or on their battle with the opposition (as in case of the 1995-96 electoral cycle). In such a situation public administration was granted only minimal attention.

After the 1996 presidential elections President Yeltsin and his team turned their attention to the deteriorating system of national bureaucracy for the second time. Analyzing results of the first transitional period of reforms, an established team of experts and politicians came to a conclusion that the system of governance in Russia needed more than just modernization. Rather it demanded radical transformation of literally all aspects of public administration activity. An idea of a complex approach to the reform that combined two distinct reforms of public institutions and civil service, emerged at that point. This idea was realized in the 1997 "Conception of Administrative Reform" (hereafter referred to as the 1997 Conception), as prepared by the group of experts headed by Mikhail Krasnov. 
A new round of reform attempts was inspired by this political demand, and may be connected to the changes in the government, which was enriched by the group of liberally minded officials, named as 'mladoreformatory'. On May 7, 1997 President Yeltsin signed a decree that established a special commission on the reform. ${ }^{68}$ Formally the commission was headed by the Head of Administration of the President, Valentin Yumashev, and included many prominent and liberally minded persons. During the next two years, it prepared twelve versions of comprehensive and detailed plans of reform.

One of the main features of these plans was meticulous analysis of all aspects of the reform of the public service: from an overarching and conceptual political framework as well as fundamentals of the public service, to a detailed step-by-step instructions for their implementation. The commission implemented an academically scrupulous and comprehensive approach, while preparing the conception and related documentation. Experts analyzed major trends in international public service reforms, assessed outcomes and the process of the reforms in major western countries, in which reforms had already been implemented and initial results received. These countries could be split into three clusters according to the 'degree of departure' from the 'classical model' of public administration. Some countries (New Zealand, United Kingdom, Australia) took a rather radical approach to modernization of their bureaucratic apparatuses with large-scale privatization of publicly owned companies and common use of outsourcing in the provision of public services. These countries significantly reduced the size and areas of responsibility of their public sectors. Some other countries, like Germany and France,

${ }^{68}$ Order of the President of the Russian Federation No. 176-rp from May 7, 1997 "O komissii po razrabotke proekta Programmy gosudarstvennogo stroitel'stva v Rossiiskoi Federatsii”. 
adopted a rather conservative approach to the reform, and introducing new technologies of governance only where it was needed. Yet, there were other countries (USA, Canada), where the reform agenda was somewhere in-between the radical and conservative approaches.

Adapting the results of reforms in these countries to Russian realities, experts of the commission were able to identify and formulate the major goals of the reform of public service. Thus, one of the main ideas proclaimed by the reformers was the shift in the political orientation of public officials from 'servicing the state' to 'servicing the people'. In addition to this, there were announced other, rather more conventional tasks, such as: improving the effectiveness of governance and the prestige of public work. Unlike in the first period, when the most crucial goal was to avoid disruptions in governance, during the second period, ideas of cost-effectiveness started to prevail - if not in practice, at least at the conceptual level.

As part of a larger project of modernization of the entire system of governance in Russia, the programme of public sector reform introduced several principles that determined a rather radical shift from old-type bureaucracy. Among them was the establishment of the merit-based principle of civil service. This approach stresses professionalism of public officials as the fundamental feature of the reformed officialdom in Russia. This implied, on the one hand, recruiting public employees on the basis of the process of formalized qualification examinations and tests; and on the other hand, demolition of the deeply rooted paternalist principles of modus vivendi of bureaucrats, which was not only inherited from the Soviet system, but rather reinforced during the first post-Soviet years. The programme of reform included measures to enhance 
transparency and reduce corruption. One of the most pioneering proposals on the subject matter was the monetization of professional and social benefits for public officials, and the limitation of material privileges and other nonpecuniary benefits.

Despite many timely measures proposed in the 1997 conception however, the latter never reached the implementation stage. Some experts believe that this was due to the fact that the reform was prepared and discussed by a closed circle of experts and politicians. It was never discussed publicly, or at least by a wider group of public officials at the federal and regional levels. Some authors believe that the lack of transparency during the preparatory stage was detrimental for the outcomes of the reform. ${ }^{69}$ At the same time, it is important to mention a rather unstable political situation in Russia, present during the late 1990s. The tone was set by the financial and economic crisis that struck Russia after the government announced a default on short-term state bonds on August 17, 1998. Under such conditions, reforms that were still at the preparation were put off until more stable times. Furthermore, political instability during the late 1990s was quite remarkable, as within a short period of roughly two years there were four governments with quite different political orientations. They ranged from the rather technocratic cabinet of Sergey Kirienko, to the leftist government of Evgeniy Primakov, and the rather moderate and centrist governments of Sergey Stepashin and Vladimir Putin. In such conditions, any productive reformatory attempts were impossible.

At the same time, the 1997 conception of public service reform was an important step forward in evaluating the condition of national officialdom, and developing a

${ }^{69}$ This point is often expressed by Alexander Obolonskii in his multiple publications on the subject matter. 
thorough programme for its improvement. In terms of methodology and organization of the process of designing the reform, this conception established a yardstick for any further attempts. With signs of recovery of national economy that began in 1999, and the political stabilization which resulted from the landslide victory of Vladimir Putin, the question regarding the reform was revived. At this time the Center for Strategic Development - a 'think tank' closely affiliated with Vladimir Putin's liberal ally and Minister for Economic Development and Trade, German Gref began working on the conception of public service reform.

The succession of ideology and methodology of the 1997 conception by the new team was interpreted as a genuine success by many observers. ${ }^{70}$ The newly formed group of experts included several members from the previous one. Many key scholars in the field of public policy and civil service were also included in the pool of experts and various working groups. Although the new pack of documents for the reform of public service was based on principles inherited from the 1997 Conception, it emphasized new challenges and opportunities that the ruling political elite was going to face when they started implementing the reform. The new conception that resulted from this process stressed the fact that the previous decade shattered the very fundamentals of the state apparatus in Russia. Political instability resulted in the loss of public credibility by institutions of the state. The political sphere was highly personified, and only certain individuals were trusted. Public opinion polls indicated a very low level of trust for major state institutions. At the same time, the measurements of public dissatisfaction with weak

${ }^{70}$ See for example: A. Logunov (ed.), (2006) “Administrativnaia reforma v Rossiiskoi Federatsii: osnovnye etapy realizatsii". Analytical Bulletin of the Federation Council of the Russian Federation. Ser.: Problems of State-Building No. 22(310), p.21 
and merely dysfunctional governmental organizations were quickly increasing. All these issues were addressed in the Conception for Reform of the System of Public Administration that was prepared in 2001 (hereafter referred to as the 2001 Conception) and approved by the president. ${ }^{71}$ Its authors made a significant step forward in comparison with the previous stage, regarding the process of reform implementation. Their work was put at the core of the reform that began in 2003 and is still under way.

The review of the first decade of post-Soviet bureaucracy reveals several of its crucial features that determined difficulties in implementation of any significant reform projects. On the one hand, these difficulties, and sometimes even mistakes, were made mainly due to the nature of the public service itself. On the other hand, mistakes were made during the intellectual assessment and interpretation of the institution of Russian public administration. The lack of political will and interest in reforming the bureaucratic apparatus, as well as mistakes in determining major vectors of transformation, resulted in the fact that during the 1990s, the state apparatus did not undergo any significant reform, and kept deteriorating by all significant indicators: level of expertise, efficiency, age, gender, education, prestige, remuneration etc.

As some scholars outline, analysis of the bureaucratic apparatus has always been a challenging task. ${ }^{72}$ One of the main reasons for this, is the corporatist tradition that lasted for centuries. This tradition is also reinforced by hypertrophied paternalism. Indeed

\footnotetext{
${ }^{71}$ See: Decree of the President of the Russian Federation No. Pr-1496 from August 15, 2001 "Kontseptsiia Reformirovaniia Sistemy Gosudarstvennoi Sluzhby Rossiiskoi Federatsii."

${ }^{72}$ See for example: Alexander Obolonskii (1996) "Postsovetskoe chinovnichestvo: kvazibiurokraticheskii praviaschii klass." Obschestvennye nauki i sovremennost'. No.5, pp. 5-15.
} 
for many years Russian public service was not only a secretive and rather closed social stratum; it adhered to a feudal principle of servicing the patron. Insufficient and often unenforced legislation also created opportunities for the existence of informal and corrupt practices, used by bureaucrats in fulfilling their duties. These factors significantly impeded studying and finding the true reasons of bureaucratic ineffectiveness. It was tempting therefore to adhere to an approach of direct adoption of the western rhetoric and ideas for the reform of the officialdom. Using a rather rhetorical formula of the omnipresence and excessiveness of the state apparatus in Russia - a phenomenon that is, as discussed above, actually refuted by statistical data - hid behind the true drawbacks of the bureaucratic apparatus. Political leaders almost immediately recognized the importance of retraining and re-educating public officials who worked within the Soviet system for their entire career. Yet, a focus on institutional aspects, e.g. bargaining over material, technical and even human resources, the basis of former system of Higher Party Schools did not contribute to the quantitative changes in the system of Russian bureaucracy. The absence of high quality teaching staff was amplified by the aspiration of new leaders for the adaptation of Western governance technologies and principles. Yet in the end of the first post-Soviet decade, it had become obvious that it was not the institutions of the state that urgently needed radical reform. Rather, it was the entire cadre of the public service that preserved some of the principles of the Soviet nomenklatura which needed fundamental restructuring. Among the biggest issues of post-Soviet public service in Russia, experts identify continuity of the personnel on all levels of bureaucratic apparatus as critical. The 'continuity of nomenklatura' hypothesis supports the argument 
that post-Soviet public administration has become even more inefficient than the Soviet one because it not only secured old deficiencies, but introduced $t$ new ones. ${ }^{73}$

\section{Conclusion}

This chapter described major difficulties, that the Russian state apparatus in general, and the federal government in particular, faced during their evolution in the first decade of independence. It was shown that the governmental structures were changed in response to external challenges and such the reactive nature of building the state, could not help to positively affect the efficiency and adequacy of the structural arrangement of the executive branch. During the period of the dismantling of the Soviet Union, the government of the RSFSR had to be adjusted in order to be capable of substituting the Union's executive bodies on the territory of Russia. Taking into consideration the complexity of the Soviet governance structures, this task was rather a challenging one, as some governmental structures had to be established from scratch.

Being put under parliamentary control, and suffering from many procedural deficiencies, the government itself was the subject of political bargaining between the Supreme Soviet and President Yeltsin, rather than being the major source of social and economic decision-making. After the constitutional reform of 1993, the Russian government obtained its current legal and functional characteristics. Yet due to political instability and a weak economic situation in the country, it had to respond to emerging challenges, rather providing a program of long-term development for the country. President Yeltsin delegated to the cabinet, immediate responsibility for the current social and economic situation, securing for himself the role of the arbiter. He actively used his

\footnotetext{
73 Alexander Obolonskii (1996) "Postsovetskoe chinovnichestvo: kvazibiurokraticheskii praviashchii klass.” Obshchestvennye nauki i sovremennost'. No.5, pp.5-15
} 
right to reshuffle the cabinet according to contemporary political situations. In addition to this, the State Duma still exerted some level of influence over the work of the government, making the latter a primary object of its criticism and political action, influencing the appointment of some prime-ministers, and attempting several times to pass the vote of no-confidence. Such a situation did not contribute to a stable and gradual evolution of the cabinet. Instead, it resulted in structural complexity and functional uncertainty of the central government. Furthermore, the situation worsened due to complicated relations between central and regional state institutions.

Obviously, such a troubled history of development of the governmental apparatus had a drastic impact on its performance. The situation of the federal government after the 1996 election shows that in many instances, it was a 'subsidiary coin' in Boris Yeltsin's attempts to conduct liberal reforms in the country and, thus, the inevitable struggle with the leftist Duma. By the end of 1990s, it had become very clear that the current system of executive bodies is one of the most significant impediments for modernisation of the country. Improved economic conditions and enhanced public stability (related to the restored power vertical) created favourable conditions for the reform of the state apparatus.

Conflicts and tensions within the government also affected the effectiveness of the entire executive branch. Top executives put a lot of effort into preserving and/or improving the status of their agencies. Regardless of intense internal political processes most ministers were able to survive reshuffles and usually only minor and insignificant changes occurred during the governments' tenure. For approximately one decade, the system of governance did not have any particular vector of development that might create 
a sort of yardstick for assessment of appropriateness of one or another institution. Instead, the governmental body strived to expand its authority, privileges and funding, ultimately creating a situation of structural complexity and functional confusion. One particular governmental function could appear not only under the jurisdiction of several agencies; it also might be regulated by contradicting by-laws issued by these agencies.

At this point, the imperfection of the system of governance had a detrimental impact on the overall process of the post-Soviet transition in Russia. Peter Stavrakis explained the major reason for the failure of the liberal reforms, as the unwillingness of the reformers' "to concentrate on the parallel task of restructuring the government bureaucracy which... reverted to the ministerial feudalism of Soviet days. ${ }^{, 74}$ Thus the dynamics of post-Soviet public administration clearly testifies the need for urgent and radical reform that will transform not only the relationships between government and other branches of power, but also within the executive institution itself.

\footnotetext{
${ }^{74}$ Peter J. Stavrakis (1993) "State Building in Post-Soviet Russia: The Chicago Boys and the Decline of Administrative Capacity" Occasional Paper No.254. Kennan Institute for Advanced Russian Studies. p. 56.
} 


\section{Chapter III. The Choice of Model}

\section{Introduction}

Earlier chapters showed that Russian public administration urgently needed reform. There were institutional and functional demands for the transformation of the system of governance that had been growing during the first post-Soviet decade. Institutions of public services underwent some radical changes and, to a great extent, reflected changes that occurred in state building in Russia after 1991. However, these institutions were unable to respond effectively to challenges of the market economy and political liberalization. In the new millennium, the state apparatus appeared as the epicenter of fundamental transformation of the political system. It was pronounced the major impediment to further development and stabilization of the government in Russia and, thus, was destined to be reformed. At the same time social, economic and demographic characteristics of public service demanded rapid responses and in-depth modernization of not only institutions but also human resources management policies.

Thus, the primary goal of this chapter may be outlined as not to give a full and exhaustive compilation of theories of public administration that have been created since the beginning of the discipline; but rather to stress the major alternative approaches to public administration theory that dominate contemporary discourse and provide potentially useful solutions for modernization of state apparatuses and civil services around the globe.

The New Public Management (or NPM) model, chosen as the model of reform of Russian public administration, is assumed to be one of the factors that may contribute to 
the hardships of the endeavor. NPM is a complex and multifaceted, yet quite popular, doctrine. It produced various outcomes in different countries, but the pace and scope of its distribution around the globe gave it genuine paradigmal status. Therefore, this chapter places NPM within the political-economic context and observes its emergence and evolution in the $20^{\text {th }}$ century. Development of the modern state and its apparatus goes hand in hand with economic processes. These two can be separated only for analytical purposes, but also in order to portray the holistic picture of the development of a nation, economy and public administration, and must be assessed in dynamic of their mutual influence. The justification for such an approach can be found in the two major paradigmal shifts in the development of western civilization in the $20^{\text {th }}$ century. Both times, in response to economic hardships, nations managed to increase and later shrink their public administrations. In the Russian case, the economic context also fostered growth of public attention to modernization of public administration.

The chapter also reviews major alternatives to NPM as they emerged prior to, in response to, or independent of it. These alternative concepts are assessed in terms of their theoretical foundations as well as practical applicability to the Russian case. The chapter is aimed at answering the question on whether there was a theoretical alternative to NPM in the Russian case.

\section{Public administration theory: from classics to post-modernism}

Overall, it is not an exaggeration to say that the study of public administration is a relatively new discipline. By some accounts it stems from The Federalist Papers of the late $18^{\text {th }}$ century, which provided the basis for understanding government and its structure 
as a separate and unique entity that differs from general political theory and philosophy. ${ }^{1}$ Yet, recognition of public policy and public administration studies as an academic discipline occurred over a century later. It is connected with the names of such distinguished scholars and political figures as Woodrow Wilson, Max Weber, Frederick Taylor, Luther Gulick, Harold Lasswell and others. Woodrow Wilson can be considered the actual 'founding father' of the discipline after his seminal article 'The Study of Administration' (published in 1886), public administration studies flourished in the 1920s in both the United States and Germany. The rise of the discipline was intertwined with the positivist and behavioral revolutions that took place in the social sciences at the very same time.

Over the following decades, public administration and its theory as a crucial component have developed substantially. A myriad of different approaches towards the study of public administration have been developed since. Versatility of the theoretical component can be considered as a definite benefit for the discipline, as it prevents public administration from scholasticism. At the same time, it creates definite difficulties for categorizing and arranging the scope of theoretical approaches to public policy and administration.

Although attempted classifications could be considered vague, they are nevertheless useful because they outline the major ideas and principles that were used by politicians and experts in designing the reforms in different countries. The first and the most fundamental distinction would be between normative and empirical theories. These

${ }^{1}$ See for example: H. George Frederickson et all. (eds.) (2012). The Public Administration Theory Primer. $2^{\text {nd }}$ ed. Boulder: Westview Press. 
two clusters of theories are driven by two fundamentally juxtaposing logical principles deduction and induction. Although, the epistemology behind these two approaches is different, they do not contradict each other. Speaking pragmatically, both types of theories, if built properly, are necessary and mutually complementary as they tend to answer quite different questions. Normative theories in public policy build conceptual frameworks regarding legal, functional and institutional arrangements of governmental bodies, as well as describe principles of behavior of public officials. At their best, such theories develop instruments for achieving the desired objectives. Empirical theories are aimed at working with existing phenomena of public life, in order to discover actual cause-and-effect relations and further improve the understanding of these phenomena. Such theories are useful for correction of normative theories, bringing the latter 'back to reality'. At the same time they help in creating correct scenarios for practical implementation of reforms. Theoretical approaches that dominated public administration studies during the last century, were predominantly normative in nature. Weber's ideallytypical conception of bureaucracy, 'taylorism', as well as the most outspoken implementations of the New Public Management theory - 'thatcherism' in UK and 'reaganomics' in USA - all are examples of normatively dominant theories.

Another classification of theoretical approaches corresponds with broader, paradigmatic transformations in humanitarian disciplines in general, and in the philosophy and methodology of science in particular. This classification arranges theories more or less on a temporal basis. With respect to public administration, experts tend to speak of such approaches as Marxism, positivism, behaviorism, and even postmodernism. These approaches created the basis for a variety of theories of public 
administration. Among many others, there could be mentioned 'rational choice theory' as well as some theories of bureaucracy, such as the group approach (D. Truman), policy networks (H. Heclo), or corporatism.

There may also be mentioned some meta-methodological approaches that influenced principles of theory building and conducting empirical research. In this regard such approaches as system analysis, structural-functional and institutional analysis are to be mentioned. Obviously, this list is not complete as far as the detailed review of the entire theoretical aspect of public administration studies lies beyond the goals of this chapter. Moreover, many classifications are not mutually exclusive and different theories appear in many of them and are included in various clusters. This sketchy review only tends to show how versatile and rich is the area of theoretical exploration in public administration studies.

Yet there were several theoretical approaches that, to a great extent, dominated the discipline. It would not be a great exaggeration to say that debates on the theory of public administration are placed in an area within a quadrant, the vectors of which signify both the mode of conduct of public officials and level of control of the state over economic and public life. This model is driven by a pair of fundamental debates in political and economic disciplines. The political debate is mainly about the ways of conducting public policy. The major question raised here is whether public officials' conduct should be highly regulated and restrained by law, or alternatively, public officials should be granted more freedom in order to provide public services of better quality. The economic debate is about the degree to which and in what form the government should be able to intervene into economic activities of the country. Thus, this conceptual field is 
bounded by four theoretical approaches. With respect to political vector it is common to outline an ideal model of bureaucracy represented in the works of Max Weber on the one hand, and thus the managerial approach culminated in the New Public Management school of public policy. With respect to the economic vector, governmental interventions into the economic realm were explored and justified in the works of J.M. Keynes and his adherents. The opposing view was presented in works of such philosophers as L. von Mises, F. von Hayek, M. Freedman and their followers. To put it simply, the political vector shows the degree of regulation in public administration; and the economic vector shows the degree of active involvement of the state in economic activities.

All four approaches dominated the corresponding disciplines for decades and the way they were adopted and later subverted allows giving them paradigmal statuses. Despite their chronological sequence, none of them has lost topicality nowadays, and they still continue to shape the conceptual framework of the public policy discipline. With respect to the economic vector both Keynesianism and Monetarism were quite distinct as they were separated in time. Moreover contradictory postulates postulates set off these concepts against each other.

There was no terminological and chronological unanimity among political scientists regarding the schools of public policy. Some scholars, talking about theories of bureaucracy, refer to pioneers of the American government, Alexander Hamilton and Thomas Jefferson. The former is believed to be an advocate for a considerable level of independence of executive officials from public and political control and oversight. The latter was arguing for "an elected legislature exercising direct and heavy control over the 
president". ${ }^{2}$ There are other theories that state that the discourse of contemporary public administration is dominated by the eclectic nature of the discipline, and its ability to reconcile policy questions with "sociological and cultural aspects that change rapidly in a mass communicative global world." ${ }^{3} \mathrm{~A}$ detailed review of all theories of public policy however, lies beyond the goals and tasks of this chapter. There exist many brilliant works containing very scrupulous analysis of past and contemporary public services, as well as giving some insight about the processes of its evolution. ${ }^{4}$ The two vectors of taxonomy, which are presented in this dissertation, are useful in first place because they directly correspond with the program of reform of public administration in Russia. Secondly, they draw meaningful conceptual boundaries for creating real institutional mechanisms, capable of solving the problems of governance in the country. Thirdly, they reflects actual political debates that have been taking place in the Russian political sphere since the collapse of the Soviet Union. Roughly speaking these debates are about the paths for modernization of the country. Thus, it is important for the goals of this dissertation to outline the major conceptual characteristics of these four paradigms of public discourse and correlate them with actual documents that were put into the legal foundation of public administration reform.

${ }^{2}$ H. George Frederickson (2012). The Public Administration Theory Primer. $2^{\text {nd }}$ edition. Boulder: Westview Press., p. 15

${ }^{3}$ Eran Vigoda (2002). "The Legacy of Public Administration: Background and Review." In Vigoda. E. (ed.) Public Administration: an Interdisciplinary Critical Analysis. New York: Marcel Dekker. p.7

${ }^{4}$ See for example: B. Guy Peters (2001). The Future of Governing. $2^{\text {nd }}$ ed. University Press of Kansas. 
Issues of mutual dependence of politics and the economy, have been on the cutting edge of academic and public debates for the last two centuries. Liberal theorists saw the state as a 'necessary evil' which authority must be extremely limited. Conceptions of the market's 'invisible hand', and "state as a nightwatchman', still constitute the core of liberal (or contemporary neo-liberal) thinking. Socially oriented scholars and politicians extolled the role of the state as a tool of class struggle (V.Lenin) and it was seen as an important enforcer of the will of the ruling class. An economic approach to public administration has played a significant role in public policy theory building since the fundamental work by Friedrich Engels "The Origin of the Family, Private Property, and the State," where he outlined the basics of what later became known as historical materialism. He adopted and further expanded Marx's 'basissuperstructure' model, explaining the dependent status of governmental institutions, and the supremacy of economic relations for public life. Governments themselves, as well as different types of governments, were derivatives from existing economic formations. Such a rather radical approach was later developed into theories of mutual dependency of political (governmental) and economic spheres.

The global economic crisis of the 1930s sparked intellectual debates on the degree and forms of governmental penetration into economic life. Many ideas of public control over economic processes were summarized in the works of John M. Keynes. His approach was so influential among politicians, that it was adopted by the overwhelming majority of governments after World War II. Keynesian theory advocates for a mixed economy, where the private sector coexists with public enterprises. This approach gives governments the commanding positions in economic and social life. Keynesianism 
proclaims direct governmental participation in economic activities of a country. On the other hand the so called 'monetarists' rejected this approach. They argued, instead, for limiting the government with only regulatory functions. Classical monetarists were sceptical about the state's ability to produce the most effective solutions to the problems that a society faces. According to their logic, state apparatuses should not be directly involved in the production of public goods and should cease their activities in the economic sphere of their respective countries.

The debate over economic capacity of the state was reinforced by the political discourse regarding the modus vivendi and authoritative capacity of public officials. This latter debate was shaped by variations in interpretations of rationality. On the one extreme we observe the theory of an ideal type of bureaucracy that is completely stripped of any political intentions and represents a specific type of bureaucratic machine, based solely on the logic of following protocol. Opposite to this rule-abiding approach is the objective driven concept that argues in favour of officials' ability to manage. It is assumed that such procedural freedom for bureaucrats will give them more incentives to perform better, if it is counterbalanced by a focus on their performance.

These theories constitute an economic and political-administrative continuum. The majority of past and contemporary debates on public administration and civil service can be found within this continuum. Figure 1 provides a visualization of this conceptual approach, which frames the discussion of this chapter. Two vectors - political and economic - present the major issues that are addressed by almost any theory of governance. 
Figure 1. Political-economic continuum of contemporary theoretical debates on public policy and administration.

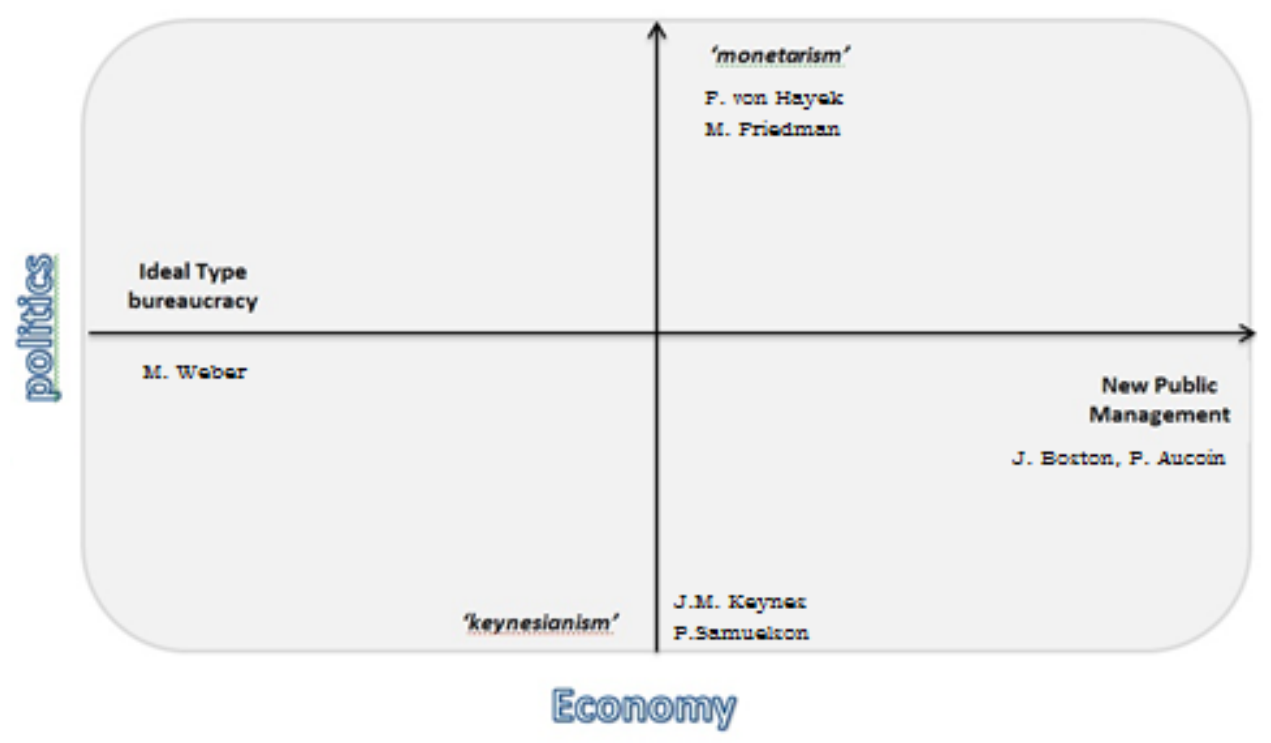

There are two vectors - political and economic. Most theories of public administration, and obviously those that are considered most influential or even paradigmal, possess definite statements on their visions of the economic and governing functions of the state. Chronologically, both vectors concurred. Max Weber's ideas on bureaucracy were published after 1922 in an essay "Economy and Society"; and the work of John M. Keynes “The General Theory of Employment, Interest and Money” was first published 14 years later - in 1936. Ideas of Milton Friedman achieved worldwide recognition in late 1970 s and were, to a greater extent, adopted in policy programmes of neo-conservative governments in the United States and the United Kingdom. The New Public Management theory originated from the early 1980s' criticism of the traditional ('Weberian'), or progressive public administration (PPA). Yet, in intellectual sphere none of the approaches was totally dominant. The ideas of Keynes were challenged by Friedrich von Hayek in the early 1940s. At the same time Ludwig von Mises criticized the ideal type bureaucracy principle. In his essay "On bureaucracy" he showed that public 
administration lacks the ability to conduct their affairs in an economic rational manner. A similar situation occurred with later theories. Difficulties in the implementation of monetarist principles of government inspired a rapid creation of neo-Keynesian theories and approaches to the economy. A critical review of major postulates of new public management was issued in the Blacksburg Manifesto, which reinstates the normative boundaries of public service. ${ }^{5}$ This brief review shows that the intellectual aspect of public policy and administration has been very intense. Yet, more important is the fact that these theories were implemented in practice and these were the worldwide processes.

Notwithstanding the intense intellectual debates, in practice two major cycles may be observed. In both instances complex factors of political, economic and technological origins contributed to sharp and rather rapid changes in the ideology and practice of governance in many countries. Global events of the first half of the $20^{\text {th }}$ century contributed to building the welfare model of state with proactive governments that penetrated deeply and heavily into economic life. This was the political-economic response to the hardships of the classical liberal lasser-fair model of governance. The state became involved in production and provision of public goods; and the nomenclature of goods and services expanded significantly. Many states adopted universal education, healthcare, and pension systems, as well as occupied positions within the purely economic sphere, providing strategic leadership in some industries.

The welfare state model of governance was dominant in the post-World War II world. Yet, it was later discredited by both politicians and academics for being the major

${ }^{5}$ Gary L. Wamsley et al. (1990). Refounding public administration. Newbury Park, Calif.: Sage Publications. 
contributor to the slowing down of economic development. It was argued that big governments became sluggish and inflexible and the welfare state had reached its culmination and become obsolete. The managerial concept captured the minds of experts with the same pace and scope as the idea of the welfare state did several decades earlier. In response to challenges of the modern era the concept of New Public Management emerged. Although, the ascent of popularity and practical implementation of the New Public Management doctrine was rather rapid, it nevertheless was not unprepared. Famous political reforms that 'reinvented government' in the United States and the United Kingdom during the late 1970 s and early 80 s, as well as other even more radical but less well known reforms in New Zealand And Australia were all preceded by intense intellectual development.

The development of NPM in the last three, or so, decades has revealed that it is a very complex and multifaceted theoretical doctrine that can receive various and, in some cases, even contradictory practical implementations. It is quite difficult to outline one solid trend in the implementation of theoretical postulates, as summed up under the umbrella of the concept of public sphere managerialism. Countries started reforms of their public administrations with different initial political, economic and social environments. This obviously influenced the choice of strategies and the reforming capacity in different cases. Moreover, objectives of the reforms and measures available also were not unanimous among those countries.

A similar situation could also be observed in the academic sphere. Scholars do not agree with each other completely regarding the boundaries and building blocks of New Public Management doctrine. Discrepancies exist regarding the causes of the reform as 
well as regarding outliers - countries that either outperform or underperform the average expectations. Two approaches are demonstrative in this regard. On the one hand, Peter Aucoin concentrates his research focus on "the Westminster systems as the locale where NPM first came to the fore." ${ }^{\prime 6}$ This focus on the Westminster system, or, broadly speaking, on the Anglo-Saxon political environment as the crucial promoter of change was questioned by Christopher Hood, who disregards this "awfulness of the English", or "the relatively poor economic performance and arrested development of welfare state policies ${ }^{\prime 7}$ that instigated change in public administration. He speaks of the cases of Netherlands, Sweden and Denmark-countries that put great emphasis on reform, according to independent observers from the OECD. Moreover, it may be stated that within the academic community there were several groups of scholars who were contributing to the development of the public management school, but represented a slightly different approaches to its values. All this allows one to speak of New Public Management not as theory, but rather as a school, or even fashion with blurred boundaries, varying methodologies and significant diversity in setting the agendas.

There were some differences in the various interpretations of major theoretical postulates of New Public Management. Donald F. Kettle posits six major aspects that distinguish NPM from other public administration theories. He speaks of an emphasis on productivity, marketization, decentralization, accountability, orientation towards service

${ }^{6}$ Peter Aucoin (2012). "The Political-Administrative Design of NPM.” In Tom Christensen and Per Lægreid The Ashgate Research Companion to New Public Management. Burlington, VT: Ashgate, p.33

${ }^{7}$ Christopher Hood (1995) The "New Public Management" in the 1980s: Variations on a Theme. Accounting Organizations and Society, Vol. 20, No.2/3. pp. 95, 97. 
provision and customer-like approach, and politicization or a "steering, not rowing" ideology. ${ }^{8}$ Christopher Hood stresses seven aspects of NPM that differ from those of Kettle, if not completely then at least in some aspects. He discusses changes of structural composition of public agencies through 'disaggregation'; competition both within the public service (between public agencies) and between public and private agencies; emphasis on managerial practices borrowed from the private sector; parsimony in use of available resources; hands-on instead of hands-off management practices; transformation of the system of quality control towards more explicit and easily measurable parameters, and performance-based as opposed to directive, "orders of the day" organization of work. ${ }^{9}$

It is safe to say that New Public Management is the most broadly recognized approach to reforming government institutions and transforming the system of relations within public administrations. ${ }^{10}$ It has been widely adopted as mainstream for modernization of state apparatuses since the late 1970s. Such widespread use of New Public Management remedies for improving performance and efficiency of national bureaucracies resulted in various outcomes in different countries. Some countries truly succeeded in governmental restructuring, while others created significant drag in implementing the reform. This situation inspired a lot of criticism about New Public

${ }^{8}$ Donald F. Kettle (2005) The Global Public Management Revolution. Washington: Brookings Institution Press, pp. 1-2.

${ }^{9}$ Christopher Hood (1995) "The "New Public Management" in the 1980s: Variations on a Theme." Accounting Organizations and Society, Vol. 20, No.2/3. p. 100.

${ }^{10}$ David Osborne \& Ted Gaebler (1992) Reinventing Government: How the Entrepreneurial Spirit is Transforming the Public Sector. Reading, MA: AddisonWesley., pp.322-325 
Management and questioned its paradigmal status. However, despite tense discussions and plenty of rebuttals, "NPM still appears to dominate the discourse of public administration, and has become the orthodox language of public administration." ${ }^{\prime 1}$

Such popularity and dissemination of NPM ideas obviously put their theoretical and methodological background under scrutiny. This was not only the result of various outcomes NPM shown in different countries. No less important were issues of what exact kinds of reforms were conducted in particular countries and questions as to why they were chosen and what were the results. The questions of variability of outcomes of managerialist reforms instigated a series of comparative investigations. One of the most comprehensive was performed by experts of the World Bank, Nick Manning and Neil Parison. ${ }^{12}$ Analyzing the flow and outcomes of reforms, they developed the concept of reform traction. Different factors, such as strength and level of corporatism or heterogeneity within the state bureaucracy, type of career development and even peculiarities of the political and partisan systems, foster countries to take one or another path in the reforming process. Countries can be defined as low- and high-traction ones with respect to the pace of the reform, and according to the acceptance and adaptability of public servants to principles of new public management.

A variety of choices and differences in implementation of NPM policies also raised concerns regarding solidity of the concept. Indeed, reforms of public

${ }^{11}$ Pauline Dibben and Paul Higgins (2004). "New Public Management: Marketization, Managerialism and Consumerism.” In Dibben, P., Wood G., Roper I. eds. Contesting Public Sector Reforms: critical perspectives, international debates. Palgrave Macmillan. p.26.

${ }^{12}$ Nick Manning, Neil Parison (2004). International public administration reform: implications for the Russian Federation. Washington: The World Bank. 
administrations in such European countries as the United Kingdom, France, and Germany, differ drastically even in terms of how thoroughly were implemented the most common NPM principles. Moreover, the entire package of measures proposed by national governments differed substantially. France for example, has been seriously influenced by the administrative and corporatist ideology of the Napoleonic type of state, has one of the most powerful civil services in the world. Moreover, corporatist ideology is widely accepted (although usually criticized) by French citizens. Human resource management of the French bureaucratic system is quite different from any other country. Careers of public officials may slip between the public and private sectors. They are allowed to leave civil service for work in the private sector and later return to their administrative duties "with no loss of seniority or pension benefits". ${ }^{13}$ Such a system of pantouflage differs fundamentally from the Weberian approach towards the public sector where independence and continuity of the state apparatus is based on its separation from any form of external pressure and emphasis on the legal and procedural aspects of public service. The German state, regardless of numerous reforms, also "continues to be an example of classical Weberian bureaucracy", and its "central features have not changed a great deal over time." 14

All this creates a special approach towards New Public Management not as a solid and coherent programme of reform with carefully scheduled specific measures and

${ }^{13}$ John A. Rohr. (2005) "French Public Administration." in Krishna K. Tummala (ed.) Comparative Bureaucratic Systems. Lanham: Lexington Books., p.46

${ }^{14}$ Walter J.M. Kickert (2011). "Public Management Reform in Continental Europe: National Distinctiveness." in Christensen T., Lægreid P. (eds.) The Ashgate Research Companion to New Public Management. Burlington, VT: Ashgate. p. 102 
policies. New Public Management is more like a 'toolkit' of separate, sometimes quite different, but at the same time ideologically intertwined reforms, programs and policies. Yet, these 'tools' are primarily pragmatic; that is they provide mechanisms and principles of conducting reforms.

NPM appeared on the horizon of public administration theory as a result of deficiencies of the old system of administrative governance, which were brought to light as a consequence of a series of different crises that shook major OECD countries in 1970s. Perhaps the economic crisis of the early 1970s, also revealed other deficiencies of the previous system of governance. It may be assumed that the primary goals of all reform attempts, regardless of the sphere of their application, were aimed at enhancement (or restoration) of the efficiency of public agencies, both in terms of their productivity and cost-effectiveness, as well as in terms of improvement of their manageability. Organizations must provide goods and services that are really demanded by the people. Yet they have to produce them at minimal costs with desired quality. If we speak specifically of public organizations, these demands are amplified by the issues of public accountability and social responsiveness. The importance of the latter feature has grown immensely, especially in the case of welfare states. All reforms of public organisations were designed specifically in order to match current types of social and political relations established in one or another country. In this respect, New Public Management platform also represents a particular stage in social development. However, its goals and values remain exactly the same: "to improve the effectiveness and efficiency of the public sector; to enhance the responsiveness of public agencies to their clients and customers; to 
reduce public expenditure; and to improve managerial accountability." ${ }^{\prime 15}$ Some of these values however, received different (if not the opposite) connotations. In comparison to the previously reigning model of the welfare state, New Public Management proposes different mechanisms for increasing efficiency of public organizations.

One of the most important ideological premises of NPM is the emphasis on managerial practices and principles that were developed in the private sector. Adherents of the new paradigm see managerialism as the crucial key for enhancement of efficiency. The second premise is political, and it deals with the role of the state in the conceptual triangle: state-economy-society. Here the views of NPM proponents stem from the longexistent liberal (or in some cases libertarian) philosophy. 'State-as-night watchmen' is probably the most famous allegory that expresses the ultimate view on the subject of many of NPM theoreticians. However it might represent only the ideal type of state, which is practically non-achievable. These two major, and some other additional features of New Public Management, need a deeper explanation in order to bring the concept in concordance with its real-world implementations.

Speaking of the role of the state, NPM theorists stress issues of its size and the scope of its authority. Following Adam Smith's famous metaphor about the invisible hand of market that is able to settle the majority of disparities in the economic sphere, they prefer limiting participation of the state in economic processes. The latter are recognized as direct or indirect involvement in the production of goods and services that

\footnotetext{
${ }^{15}$ Tom Christensen and Per Lægreid (2011) Chapter 1. "Introduction." in Christensen, T. and Lægreid, P. (eds.) The Ashgate Research Companion to New Public Management. Burlington, VT: Ashgate. p. 1
} 
are related to the welfare state. Due to a variety of factors, the role of state in socioeconomic life increased significantly during the $20^{\text {th }}$ century. Governments extended their authority far beyond purely political tasks. They started playing a significant role in the production and distribution of goods and services by establishing state owned enterprises. They also significantly increased their presence in the social sphere, taking responsibility for providing such hardly quantifiable services as education, health care etc. All these factors led to the growth of the state in terms of the size of the workforce and structural complexity.

Enormously expanded Keynesian welfare states demonstrated difficulties providing sustainable development as they faced the economic crisis of 1970s and subsequent recessions. These events fostered rethinking the role of the state. A neoliberal idea of shrinking the state demanded a conceptual reframing of the entire discourse on the state. It stated that the state needed to regain flexibility and elasticity. At the same time crucial achievements of the welfare state should not be lost. ${ }^{16}$ Yet again, as centuries ago, a metaphorical formula of 'steering, not rowing' came into the fore. This formula created an ontological basis for the transformation of the state as an institution, whose role has started to be focused not merely providing goods and services, but also regulating relationships between private organizations that provide them and citizens who consume them.

The idea of a compact and mobile government of the NPM era differs from that of classical liberalism. Modern NPM theorists believe that the state should still be involved

\footnotetext{
${ }^{16}$ Donald F Kettle (2005). The Global Public Management Revolution. $2^{\text {nd }} \mathrm{ed}$., Washington: Brookings Institution Press, p.5
} 
in many spheres of social, economic and political life. This involvement however, should in principle be changed. The modern state should keep providing goods and services, commonly associated with the welfare state. At the same time it should develop new approaches towards its role in the economic life of a country, taking into an account the necessity to completely abandon direct participation in the production process. In order to achieve this objective, two major technologies were introduced - privatization and contracting out. Neither of these two technologies was not completely new, however they have become the distinguishing features of NPM administrative reforms in the sense of shrinking government.

Privatization of publicly owned enterprises was a pivotal issue of the neoconservative ideology of the last several decades. Privatization was believed to diminish the direct participation of the state in the economic life. This process was commonly defined as "the act of reducing the role of government or increasing the role of the private institutions of society in satisfying people's needs..."17

Whereas privatization is primarily targeted at dismantling the so called economic role of the state that was very pertinent to the Keynesian welfare state model, 'contracting out' deals specifically with genuinely governmental functions of providing state services to the population. In the case of its economic role, the state assumed the duties pertinent to a privately owned business enterprise and produced goods and services that were purely within the economic realm. For example, formerly publicly owned flag carrying airlines, such as British Airways, Air Canada, and Aeroflot (Russia) competed with

${ }^{17}$ E. S. Savas, (2005) Privatization in the City: Successes, Failures, Lessons. Washington, DC: CQ Press, Chapter 1. 
privately owned airlines in the global and national transportation markets, and often were given some competitive advantages due to their status - as they were not directly vulnerable to market fluctuations. 'Contracting out' is related to such genuinely public features that have always been associated with governmental duties. Such services as, for example, issuing driver's licenses are now being transferred to private organizations who act on behalf of the state. Yet here also dominates an idea that private interest and management practices will be more efficient. ${ }^{18}$ Therefore, due to social responsibilities such as this, the state should not abandon this sphere of provision of public goods and services but increase efficiency by outsourcing some tasks to the private sector. It will be even better if the state limits itself to invigilation of these services, and making sure that they are provided in full and under satisfactory conditions.

Obviously, privatization and marketization of public services were quintessential for NPM reforms in almost every country that adopted them. Yet the entire concept was not limited to these measures and ultimately aimed at shrinking the size of the state and its penetration into social and economic life. Following up the growing concerns about traditional civil service, New Public Management proposed a significant transformation of the principles of functioning and even ethics of bureaucracy. One of the major changes occurred in the perception of the public service. There was a significant impetus to transfer a managerial ethos pertinent to private enterprises to the public soil. The slogan 'let managers manage' outlined the core principles of public sector activities that was

\footnotetext{
${ }^{18}$ See for example: Emmanuelle Auriol and Pierre M. Picard (2009). "Government Outsourcing: Public Contracting with Private Monopoly." The Economic Journal, No.119 (October), pp.1464-1493.
} 
involved in some institutional and behavioral transformations. First of all, it was made clear that the classical hierarchical organization of bureaucracy did not perform well, and had to be replaced by means of creation of a quasi-market system of relations within the public sector that would foster public servants behaving as if they worked in the private sector. Institutionally, this would involve significant 'agentification' of the public sector when once unified sectoral governmental bodies would be split into many semiautonomous agencies. Functionally, this would relate to deregulation of activities of these agencies.

Agentification and deregulation of public services were complemented by changes in principles of funding the agencies and providing remuneration for public officials. As a substitution for the traditional form of resource allocation budgeting, the NPM concept proposed performance-based budgeting. This transformation was as radical as both major NPM innovations discussed above. According to the classical paradigm, funding of an agency emphasized proper functioning of the governmental body in terms of staff and equipment. Traditional budgeting concentrated on proper procedures of public service activities. Agencies were funded on the basis of their capacity to fulfill assigned duties. This form of budgeting has recently received a considerable amount of criticism. Following the Iron law of bureaucracy that discovered immanent selfreproduction and expansion of public agencies, adherents of the modern system suggested that that traditional budgeting would inevitably raise public expenditures. In response to this trend they "stressed a systematic examination of the purpose and goals of 
a program and assessment of efficiency and effectiveness." ${ }^{19}$ And the proposed changes "are directed at giving organizations and managers greater freedom in operational decisions. ${ }^{20}$ The switch to ex-post assessment of the results of the work of a public agency changed the entire approach towards understanding the nature of public organizations whose task is the provision of services. First of all, theorists hypothesized that flexibility in fund allocation within the agency would improve agencies' productivity and thus, citizens'/customers' satisfaction. Secondly, it would provide more options for change in structure and composition of an agency through opening opportunities in auditing activities of the agencies. Under this system, auditors' functions expand beyond their traditional controlling functions and include consulting. Auditors are no longer limited to checking whether monetary funds were allocated accordingly; they also assess whether the current allocation can be considered the most efficient.

Although taking a 'shrinking the government' approach, New Public Management doctrine does not suggest shrinking the nomenclature of public services, which were initially introduced by the welfare state model and have since been provided by governments. Instead, it relies on different forms of provision of these goods and services. In some instances, the model implies, the most efficient would be a complete transfer of the provision of goods and services to the private sphere, with the state only maintains the controlling function. In other instances, the state is thought to exercise a

${ }^{19}$ Meagan M. Jordan and Merl M. Hackbart (1999) "Performance Budgeting and Performance Funding in the States: A Status Assessment." Public Budgeting \& Finance. Vol.19 Issue 1., p.69

${ }^{20}$ Jack Diamond (2003). "Performance Budgeting: Managing the Reform Process." IMF Working Paper, February., p.4. Available online [URL: www.imf.org/external/pubs/ft/wp/2003/wp0333.pdf] (accessed: November 11, 2012). 
higher level of control over the process of production and provision of goods and services. In this case, the state secures regulatory functions, but other aspects are transferred to the private sector. Finally, in some instances, where it is not completely possible to assure competitiveness, as in the case of natural monopolies, the state may exercise a much higher level of involvement in the production process. The latter is true in case if the idea of marketization is not completely abandoned and the state does not maintain provision of this public good(s) and/or service(s) solely in the form a public enterprise.

There are several instruments that may be adopted to reduce governments' direct involvement into the goods/services provision process: outsourcing (or contracting out), public-private partnerships, and distribution of vouchers. ${ }^{21}$ Outsourcing lies at the core of New Public Management doctrine. It is defined as "the combination of a transfer of control and cash-flow rights to a private firm and of the possibility of government offering ex post contracts to it" and based on a premise that it "is often better than regulation." 22 This axiom has been proven in many academic studies that compared publicly and privately owned firms and suggested that in principle privately owned firms are more commercially efficient than public enterprises. ${ }^{23}$ Public-private partnership

${ }^{21}$ Jón R. Blöndal (2006). "International Experience Using Outsourcing, Public-Private Partnerships, and Vouchers." in John M. Kamensky and Albert Morales (eds.) Competition, choice, and incentives in government programs. Toronto: Rowman \& Littlefield pp. 121-160.

${ }^{22}$ Emmanuelle Auriol and Pierre M. Picard (2009) "Government Outsourcing: Public Contracting With Private Monopoly.” The Economic Journal, No.119 (October), p.1464. ${ }^{23}$ See for example: Jeffry M. Netter and William L. Megginson, (2001). "From state to market: a survey of empirical studies on privatization." Journal of Economic Literature, vol. 39, pp. 321-89. 
refers to "the design of hybrid organizations for risk sharing and co-production between government and private agents." ${ }^{24}$ This form of partnership is important in undertaking projects with a direct impetus for lowering their basic costs (such as infrastructural construction), or when there is an obvious importance in provision of the service (or production of a public good), yet economic conditions (due to high costs or risks), do not contribute to private sector's active involvement into it. Finally, vouchers create a peculiar form of provision of public services. Instead of contracting a private organization to provide particular services, the government issues individuals, entitled to this service, vouchers that may be used as a method of payment for the service on the open market. Designed to provide citizens with extra flexibility in terms of obtaining the service, vouchers can be issues explicitly (as coupons), implicitly (after the qualified citizen has chosen the provider of a service, the latter is paid for it directly by the state), or in the form of reimbursement for a service 'purchased' on the market.

The observed structural flexibility and instrumental diversity, altogether with a rather straight and manifest ideology, contributed to the fact that New Public Management grew beyond its academic boundaries and has become a sort of guidebook for conducting public administration reforms in many countries. Although New Public Management was certainly the major trend in transformation of public administrations around the globe, there were significant theoretical and empirical divergences from it in some countries. Speaking of theoretical departures, a plethora of different approaches

${ }^{24}$ Chris Skelcher (2005). "Public-Private Partnerships and Hybridity." in Ewan Ferlie, Laurence E. Lynn, Christopher Pollitt (eds.) The Oxford Handbook Of Public Management. NY: Oxford University Press., p.347 
towards governance in the contemporary world that appeared in recent years should be mentioned here. Several approaches represent a holistic outlook on the future structuralfunctional characteristics of the future governments; they also are ideologically solid and coherent. One such approach is the concept of Neo-Weberian state (NWS) that is probably the only alternative to NPM that also gives a holistic outlook of public administration. Other theories, such as the New Public Service, the neo-institutional approach or postmodern approaches, are still more at the stages of academic inquiry than practical implementation. They are more reactions about imperfections of the current doctrine, than attempts to substitute it. Nevertheless, all major existing alternatives to NPM will be discussed in this chapter.

At the theoretical level, the paradigmal status of NPM was questioned by some prominent scholars. Christopher Pollitt, for example, challenged the idea of "convergence" of the majority of local conceptions of public administration development into a global model of public administration. ${ }^{25}$ Obviously, the background for this globalization movement was the 'managerial doctrine'. He cited leading experts from various countries of Continental Europe (such as Rune Premforce and Alain Guyomarch), whose empirical works testify that "instead of a singular pattern of adaptation there have been and there are several different reform trajectories in Western-style democracies,

${ }^{25}$ Christopher Pollitt (2007). "Convergence or Divergence: What has been Happening in Europe?" In Pollitt C. et all. (eds.) New Public management in Europe. New York: Palgrave MacMillan. pp.: 10-25. 
largely predicated on historically-determined patterns of state-society relations and significant variations in political cultures. $" 26$

Another type of rebuttal is raised by the prominent American scholar B. Guy Peters, who criticized the omnipresence of the ideology of privatization and shrinking the state by saying that "[i]f the problems had been easy or profitable, they probably would have remained in the private sector, and government would never have been made responsible for them. ${ }^{27}$ Moreover, immediate neo-conservative response to economic hardships of 1970s in some OECD countries resulted in restitution of some characteristics of traditional bureaucracy. ${ }^{28}$

The practice showed differences in the degree to which countries adhere to the ideas of New Public Management. In the academic environment, the role of NPM has been dominant but not exclusively so. In recent years (as some researchers called them a post-NPM period ${ }^{29}$ ), there appeared some theories and concepts that certainly surpass the boundaries of the economic-administrative conceptual framework discussed earlier in the

26 Ibid.

${ }^{27}$ B. Guy Peters. (2001) The Future of Governing. Lawrence: The University Press of Kansas. p. 1

${ }^{28}$ This idea is discussed in detail in Patrick Dunleavy's (et.all) article New Public management is Dead - Long Live Digital-Era Governance. Journal of Public Administration Research and Theory. B. Guy Peters (2001) (op.cit) also comes to the same conclusion.

${ }^{29}$ A plethora of scholarly publications dedicated to the new era of public administration thought emerged recently. For example refer to: Tom Christensen, Per Lægreid (2011), "Chapter 2. Post-NPM Reforms: Whole of Government Approaches as a New Trend," in Sandra Groeneveld, Steven Van De Walle (ed.) New Steering Concepts in Public Management. (Research in Public Policy Analysis and Management, Volume 21), Emerald Group Publishing Limited, pp.11-24. Wolfgang Drechsler (2005) "The Rise and Demise of the New Public Management." Post-Autistic Economic Review, Issue No 33, September, pp.17-28. 
chapter. There were several academic attempts to critically reappraise the managerial movement and to re-establish the government. The first attempt was undertaken by the neo-institutional movement in social sciences. Following the seminal work of March and Olsen "Rediscovering Institutions", neo-institutional thinkers questioned minimalism and attempts to shrink government ${ }^{30}$ brought by the neo-conservative thought.

Regardless its wide academic acceptance however, neo-institutional theory of public administration has not been able to substitute for the New Public Management paradigm. It was further developed into the theory of the neo-Weberian state. The term was proposed by two European authors Christopher Pollitt and Geert Bouckaert; which was not surprising because Western Europe was the major territory where NPM ideas were really struggling to become the leading agenda for policy change. Some other scholars picked up the idea of "reinventing Weber", stressing that the managerial model undermined such political values as "macro-level social trust in society". ${ }^{31}$ Critics of NPM emphasize that the issue of citizenship has been diminishing in the neoconservative paradigm. They argue that treating citizens as customers of public services ultimately undermines social cohesion and diminishes the political role of the state. Modi operandi and flexibility in rules, as prescribed by the NPM doctrine, conflict with the Rechtstaat mentality that dominates in Continental Europe and demands clear legal frameworks and boundaries that delineate and limit the authority of the state.

${ }^{30}$ See: Bryan Evance and John Shields (1998). Shrinking the state: Globalization and public administration "reform". Fernwood

${ }^{31}$ Joe Pierre and Bo Rothstein (2011). "Reinventing Weber: the Role of Institutions in Creating Social Trust.” In Christensen T., Lægreid P. (eds.) The Ashgate Research Companion to New Public Management. Ashhate. p. 405 
Adherents of the neo-Weberian model of government (hereafter NWS, that is neoWeberian State) reaffirm the role of the state and its apparatus (e.g. bureaucracy) in the contemporary world. Public offices, as multi-purpose entities, are not only service providers. They also play a leading role (alongside civil society, however) in countries' agenda setting and policy development. Yet, this return of Weberianism is not a mere restoration of the old paradigm. Academics accept achievements in theory and practice of governance made by managerialists in 1980-1990s. They suggest that classical statements of Weberian theory, such as political-administrative dichotomy, legal clarity, and the distinctive status of public service, should necessarily be reinstated. However they have to be supplemented by some new ideological derivatives. Christopher Pollitt argues that the idea of a client-oriented civil service should not be abandoned. At the same time, it does not mean adoption of market principles, but rather "the creation of a professional culture of quality and service" ${ }^{, 32}$. The state apparatus should not only follow legal requirements and act within the legal framework, but also anticipate citizens' demands. Contemporary public officials should not only be constrained by the legal framework but also be motivated to achieve results. Therefore, the 'bureaucrat' becomes not simply an expert in the law relevant to his or her sphere of activity, but also a professional manager, oriented to meeting the needs of his or her citizen/users."33

Yet, some of the practical implementations of New Public Management come into the crossfire of critique by alternative thinkers. They stress that such fundamental

${ }^{32}$ Christopher Pollitt (2007). Op. cit. p.21

${ }^{33}$ William N. Dunn \& David Y. Miller (2007). "A Critique of the New Public Management and the Neo-Weberian State: Advancing a Critical Theory of Administrative Reform." Public Organization Revue. Vol.7 p.352 
principles of NPM, as treating people as customers, have in fact nothing to do with either public good, nor with the final goals of governance related to progressive development of a nation. The following statement illustrates this critique in full:

...behaviors are changed in negative (and positive) ways because all performance measures are reactive. Police departments, when their annual budgets are being made, make more arrests that later fail because they are "false" arrests. When new student achievement tests are used to provide increases or decreases in teacher pay, teachers "teach to the test" and partly invalidate that test. When students and their families in state-funded schools are labeled "customers," evaluations of teachers (and professors) naturally focus on customer satisfaction, which sometimes has nothing to do with education or knowledge. ${ }^{34}$

Thus, from the theoretical standpoint, the differences between NPM and NWS are in the details, not in the principles. We do not observe a rapid breakdown of the old tradition and a turn to the new one. The process looks more incremental instead.

In addition, practitioners also suggest that the minimalist approach is no longer relevant in the contemporary world. Managerial state models are not capable of addressing with significant efficiency contemporary issues that modern states started to face with. Terrorism, environmental protection, natural disaster response, climate change issues, to mention a few, are among the most striking challenges that need collaborative and rapid reaction from governmental agencies. This also implies the adequacy of organizational structure of the state.

${ }^{34}$ William N. Dunn \& David Y. Miller (2007). Op.cit. pp.355-356 
An American scholar, Robert B. Denhardt proposed his outlook on the currently dominant NPM model. Finding some significant oversights and simplifications at the core of the current paradigm, he proposes to elaborate on another, more flexible model which he named 'the New Public Service' (or NPS). This approach uses a dialectical logic of progressive theory building which includes all three stages: thesis-antithesissynthesis. Derhnard analyzes 'Old Public Administration' and 'New Public Management', finds inconsistencies in both and, finally, on the basis of his findings proposes a new, rather synthetic approach.

With obvious changes in the logic of public administration that occurred in democratic societies in the $20^{\text {th }}$ century, the model of traditional, hierarchical and centralized bureaucracy is no longer applicable. However, its substitute - NPM - also has significant disadvantages. The major critique of the latter stresses its oversimplification of the process of governance. Being heavily grounded in the public choice theory, the New Public Management model concentrates on economic efficiency of public service leaving other important features of governance, such as democratic citizenship and the public interest, if not undervalued, than rather subordinated. ${ }^{35}$

Instead, the New Public Service approach elaborates on the achievements of NPM. It shares an understanding of the changing nature of governance in our current world due to complications of public life and economic process. Yet, NPS does not neglect some values provided by the classical model of public administration, such as political neutrality of public officials, procedural rationality and legal restrictions that

${ }^{35}$ Robert B. Dernhard, Op.Cit., p. 557 
bind daily practices of public officials. Taking all these considerations into account, the New Public Service proposes seven major features that should transform the contemporary theoretical outlook on $21^{\text {st }}$ century governance. They are: 1) 'serving, not steering' approach, 2) focusing on the public interest, 3) 'think strategically, act democratically' formula, 4) 'serving citizens, not customers', 5) complex look on accountability, 6) valuing people, and 7) superiority of citizenship over entrepreneurship.

The first idea represents the further development of NPM approach of 'steering, not rowing' society. As NPM rejected the role of state as the major provider of public goods and services, NPS posits that "[g]overnment acts, in concert with private and nonprofit groups and organizations, to seek solutions to the problems." ${ }^{36}$ Thus, the role of government is transformed. It is no longer the sole producer; nor is it in charge and in total control. The active function of the government is present, but transformed. The active role of government in agenda setting is reflected in the second idea of focusing on the public interest; it is also seen in the third one. NPS understands the major role of the government in creating arenas for elaboration of further visions of development of state and society. Yet, the fourth idea focuses on society more than on public administration. It criticizes the dominant 'mantra' of New Public Management about treating citizens as customers as minimalist and misguided. The government still must provide services to the people, but it must recognize their active engaging role, not their passive consuming attitude. From this perspective, citizens themselves must have a deliberative view on public administration. The final point that NPS stresses, is the rather more complex

${ }^{36}$ Robert B. Dernhard, Op.Cit., p.553 
nature of accountability in public service. Dernhardt posits that issues of accountability cannot be reduced to classical hierarchical bureaucratic accountability with top level bureaucrats answering to elected officials. Nor is it possible to reduce accountability to the agency's performance, as NPM suggests. Public servants inevitably are involved in reshaping and transforming the public agenda by virtue of the nature of their work. Thus, they "should be influenced and held accountable to complex constellations of institutions and standards." ${ }^{37}$ Finally, the last two concepts complement each other. They both question NPM core ideas of effective and entrepreneurial state as being not suitable for democratic governance.

With some obvious conceptual innovations, the New Public Service theory has its drawbacks. They mostly lie in the sphere of practical implementation. Adherents of the New Public Service approach understand its obvious normative status. Yet, they also claim that both other paradigms of public administration discipline are also predominantly normative. ${ }^{38}$ Such a holistic normative stance however, might be more desirable as a model for public administration reform. In comparison to reductionist approaches of both traditional bureaucratic, and new managerialist models, it brings too many hardly achievable variables and prerequisites, that the NPS appears to be more like an ideal model, rather than a practical guidance for public administration reform.

Yet, another school of thought must be mentioned here. It is the so called postmodern school of public administration theory, which has quite deep roots in philosophical traditions and epistemology of postmodernism, post-behavioralism and

${ }^{37}$ Robert B. Dernhard, Op.Cit., p.556
${ }^{38}$ Robert B. Dernhard, Op.Cit., p.551 
hermeneutics. Being rather exotic in terms of practical implementation of its ideas, the postmodern school has become a rather remarkable area in the field of public administration theory. Its members constituted the core of the famous Public Administration Theory Network (PATnet), an organized community of scholars who share post-positivist views on public administration. As it becomes clear from their general ideas, postmodern public administration theory rejects the logic of positivism that implies objective and instrumental treatment of political reality.

In practice, postmodernists criticized both classical and new public management approaches to public policy and administration as epistemologically being based on misguided principles of positivistic logic. ${ }^{39}$ They criticize the classic paradigm for being too deterministic and scientific. They argue that the positivistic emphasis on efficiency through rationality is fallacious. Hierarchical bureaucratic models built on the basis of this principle do not reflect reality as they ignore basic principles of people's actions. ${ }^{40}$ Understanding modernity and its practical implications (e.g., classical hierarchical bureaucracy) as "particularly authoritarian and unjust", postmodernists transfer the focus to processual and procedural aspects of public administration. They suggest rethinking the role of the state under postmodern conditions, calling it an artefact of modernity. According to their logic, diffusion of sovereignty has been occurring in the contemporary world. Under the trend of globalisation and with growing importance of

${ }^{39}$ See: David J. Farmer (1995) The Language of Public Administration: Bureaucracy, Modernity and Postmodernity. Tuscaloosa: University of Alabama Press

${ }^{40}$ H. George Frederickson et. all. (2012) The Public Administration Theory Primer. Boulder: Westview Press. pp. 131-142

${ }^{41}$ Ibid. p. 143 
multi- and supra-national economic and social organisations, the old legitimacy of a nation-state diminishes. Instead, various networks that often overlap traditional borders become more and more prominent in setting the world's agenda. In such conditions national public administrations have found themselves being asked who they are actually serving. Thus postmodernism was successful in outlining fundamental deficiencies of dominating theories and approaches.

Following the deconstructive trend once inspired in the depths of philosophy, postmodern public administration theorists were unable to propose a solid positive outlook on the future of bureaucracy and public policy. Therefore "[p]ostmodern public administration is perhaps best viewed as adding a tool to the public administration toolkit". ${ }^{42}$ Providing deep insights into epistemology and methodology of public administration as an academic discipline, postmodernism failed to set up a practical agenda that proposes a distinct type of public administration reform, not just generalized principles and abstract schemes. Its contribution beyond the academic sphere is almost intangible.

Yet another school of thought on contemporary public administration is worth paying attention to in this chapter. It is related to a group of American scholars from Virginia Tech's Centre for Public Administration, who in the early 1980s started a new and quite influential wave in public administration theory, crowned by The Blacksburg Manifesto. Although this paper was subjected mainly to the state of affairs in American government (particularly during the Carter and Reagan presidential administrations), it

${ }^{42}$ H. George Frederickson et. all. (2012) The Public Administration Theory Primer. Boulder: Westview Press. p. 164 
proposed a rather different than NPM outlook on governance and, thus is a relevant issue for a deeper inquiry. It was born in times of, perhaps, the highest criticism of traditional institutions of government by all parties involved: politicians, the academic community, as well as common citizens. Yet the Manifesto proclaims a rather opposite view. It argues for an appreciation of public institutions as essential instruments of contemporary governance. Its authors legitimized state institutions as inseparable feature of governance by arguing that their very existence is defined in the Constitution of the USA. Furthermore, they also suggested that diminishing their role is rather deteriorating for the governance process in general. Functions of governmental agencies in times of modernity have become more complicated and diversified, including not only pure production and (re)distribution of public goods, but also those of "executive advice, consultation and policy oversight", and thus, "the federal bureaucracy was pressed into service to perform... key constitutional functions". ${ }^{43}$

The Blacksburg Manifesto does not simply portray public service as essential and, therefore, non-diminishable. Its contribution was in proposing a discourse of reassessment, not simple reduction of public institutions. If public institutions are essential and legitimate, then perhaps procedural and normative aspects are subjects to development and transformation. It was a rather drastic shift in academic discourse on governance from merely quantitative indicators that reflect the size of state apparatus and degree of its involvement into public life, to qualitative ones that stress importance of concordance of those norms and values that currently exist in society and those that

${ }^{43}$ Kenneth J, Meyer and Laurence J. Jr. O'Toole (2006) Bureaucracy in a Democratic State: A Governance Perspective. Baltimore: Johns Hopkins University Press. pp.38-39. 
dominate within government institutions. In other words, the major concern of contemporary public administration should be about envisioning that bureaucrats pursue public good and act in concordance with the public interest. Conceptually, public administration appears to be the mediator between discrete interest groups, organizations and citizens. This concept perfectly fits into the principal-agent model that focuses on subordination of public administration to political control and emphasizes the aspect of 'servicing' in the definition of public service. ${ }^{44}$

Yet, appreciation of public institutions in The Blacksburg Manifesto was not a simple reinstatement of the pre-NPM model of government. Instead, it has brought another perspective in which public agencies were actively involved in the process of agenda setting and conflict resolution. As some scholars have noted, this was a fundamental philosophical shift from the functional to interpretive paradigm. ${ }^{45}$ The functional paradigm concentrates on established and societal structures and institutions in which individuals are perceived as no more than role players, or actors ${ }^{46}$; in other words, current performers of a particular societal function. On the other hand, "[i]nterpretivists hold that the enactment or construction of meaning through the use of language is

${ }^{44}$ Garry Wamsley (et. all). (1990) Refounding Public Administration. Newbury Park, CA: Sage Publications.

${ }^{45}$ Gary S. Marshall and Orion F. White Jr. (1990). "The Blacksburg Manifesto and the Postmodern Debate: Public Administration in a Time Without a Name." American Review of Public Administration. Vol.20, No.2. pp. 61-76

${ }^{46}$ Quite similar approach is seen in Guy Debord's (1977) The Society of the Spectacle. Detroit: Black and Red. 
inextricably involved with social process itself." ${ }^{47}$ Thus, the Manifesto proclaims bureaucracy's active and engaging role in social construction of contemporary reality. According to the critics, the document stands in between modern and postmodern perspectives, and as such is seen as an example of high modernism ${ }^{48}$ because institutions of governance are seen as rationalizing and promoting progress. Yet, understanding public administration as an important tool of creating a discourse where different social issues are discussed and solutions are found, makes it relevant to the postmodern perspective. At the same time the Manifesto itself, wittingly or unwittingly, portrays itself as value free, as far as authors do not specify what norms and values (apart, perhaps, from those mentioned in the Constitution) are included in the discourse. From a practical perspective, the Manifesto represented another alternative to the New Public Management perspective on democratic governance that stresses holistic views on public sector agencies, but suggests improving their value and ethical aspects.

Finally, a rather contemporary theoretical approach, which is also built on rejection of the ideology of New Public Management, must be included in the discussion as far as it reflects current practical issues of governance. This approach stresses changes in the modus operandi of contemporary public service that occurred in result of the breakthrough in informational technologies. Operational changes based rooted in allembracing automation and computerization, also demand rethinking of the general

${ }^{47}$ Gary S. Marshall and Orion F. White Jr. (1990). The Blacksburg Manifesto and the Postmodern Debate: Public Administration in a Time Without a Name. American Review of Public Administration. Vol.20, No.2. p.64

${ }^{48}$ Shriram R. Maheshwary, (2002). A Dictionary of Public Administration. New Dehli: Orient Longman. p.62 
structure of public sector created during the NPM era. Adherents of this approach introduced a new concept of Digital Era Governance, that must (and according to them will) surpass the NPM paradigm. ${ }^{49}$ Interestingly enough, this school portrays itself not as logical development of New Public Management as a result of the significant growth of the IT sector. Patrick Dunleavy, one prominent representative of the school, contrapositions it to NPM, proclaiming no less than the death of the latter. ${ }^{50}$

Analyzing the entire scope of theoretical assessment of the contemporary state of affairs in the public sector, it is possible to come to a striking conclusion: no one theory, approach, or conception, taken in its absolute totality and completeness, provides a clear cut remedy for public administration change for the Russian case. Obvious incapability of the New Public Management doctrine makes it a very difficult project to accomplish, as it involves too many parameters of public administration, both institutional and functional, which require substantial change. And inadequacy in fulfilment of any of these demands may challenge successfulness of the entire project. Thus, building a new system of public administration on an entirely managerial model, seems like a pure utopia. Yet, completely abandoning the NPM project, is not an option either. NPM, at least in theory, creates a very desirable outlook of the state and bureaucracy. Moreover, practical successes of NPM-oriented reform designs in some countries (New Zealand, the UK and Australia are among the yardsticks), show positive evidence for outcomes of political stability.

${ }^{49}$ Patrick Dunleavy et all. (2005). "New Public management is Dead - Long Live Digital-Era Governance." Journal of Public Administration Research and Theory. Vol.16 pp.467-494

${ }^{50}$ Ibid., p. 468 
On the other hand, new theoretical approaches, such as neo-Weberian, liberal, or postmodern states, also signify crucial incompatibilities with the Russian case. Total respect of the legal framework of political and bureaucratic activity in continental European countries was further adopted in key documents of the European Union (known as Acquis Communauitaire). Emphasis on the legal and institutional parameters of public administration also demands a quite significant degree of trust in the country's legal system. All this implies that in order for the NWS model to succeed there needs to be a considerable level of democratic political culture in the civil society. And as is also well known from classical political thought, such a culture is the result of long-term political development of a nation. ${ }^{51}$ However, this aspect, as widely evidenced elsewhere, is a point of concern in the case of the Russian Federation.

Following this discussion, it would not be an overestimation to conclude that among the given theoretical alternatives, the choice of New Public Management doctrine as an underlying theoretical framework of the administrative reform in Russia was quite desirable. As many scholars agree "[t]hroughout the world, governments have begun to experiment with and actually implement benchmarking, performance-related budgeting, accruals accounting, contracting-out, public-private partnerships and so on... [making] the actual implementation and manifestations of reforms... similar in various countries. ${ }^{, 52}$ Therefore, the prominence of NPM in academic circles was reinforced by its

${ }^{51}$ Gabriel A. Almond, Sidney Verba, (1965) The Civic Culture. Boston, MA: Little, Brown and Company.

${ }_{52}$ Vincent Homburg, Christopher Pollitt, and Sandra van Thiel (2007). "Introduction." in Pollitt C. et all. (eds.) New Public management in Europe. New York: Palgrave MacMillan. p.2. 
dominance in the practical sphere. All countries that were used as references during the preparatory stage adopted various features of New Public Management; although the scope and successfulness of implementation differed substantially. Taking into consideration the fact that the technocratic group (discussed in the previous chapter) in the Russian government was made responsible for development of the reform design, the choice of the managerial paradigm was obvious. They followed the general scholarly pattern in assessing public administration in various countries. The entire logic of the reform process demanded such a selection. First of all, public administration reform was the top priority of the reformers' clique within the political elite in general and the government in particular. (This refers to the intra-governmental composition discussed in the Second chapter). Secondly, the design of the reform was well-thought out. Many scholars and practitioners were involved in the work on the key documents of the reform. Changes of Russia's public administration were inevitable: it had to be modernized in order to match the goals of the country's development project, as proposed by the elites. The fact that the liberal wing of government took control over the development of the reform model and its subsequent implementation played a crucial role in the way the reform was developed.

\section{The design of public administration reform in Russia.}

The current reform of public administration in the Russian Federation was widely announced in the middle of Vladimir Putin's first presidential tenure. The idea that it was necessary to bring changes to government machinery was initially mentioned in the presidential address to the Federal Assembly in 2002. Among other obstacles for 
"people's efforts to live and work", ${ }^{53}$ the president specifically noted the bureaucracy. "Today colossal performance capabilities of the country are obstructed by the cumbersome, sluggish, ineffective state apparatus" ${ }^{24}$, said Vladimir Putin, thus giving a political start to the reform. However, the need for substantial transformations within the governmental body was mentioned even earlier. Vladimir Putin's 2001 Address also stressed the necessity of structural changes in the government. At that point however, the president was discussing the economic life of the country in general, and the state's penetration into it, in particular. Calling the Russian economic system a "rent-seeking, not [a] productive one" Vladimir Putin outlined the role of the state bureaucracy in preserving such an unsatisfactory status quo. He said that "the way of making money on the assets of the state: be they either state property or budgetary" had remained very popular. Obviously, in such circumstances, the plan for thorough political, social and economic modernization based on the doctrine of 'the power vertical' relied heavily on an effective state service. Among the dominant objectives of the proposed administrative reform, the president mentioned reduction of excessive governmental functions. ${ }^{55}$

As was discussed in earlier chapters, neither the demand for the reform, nor the ideas or concepts, were entirely new. The team of reformers within the Center for Strategic Development were able to maintain continuity with earlier elaborations made in late 1990s, which were not being implemented for various reasons. Moreover, the reform project was prepared not entirely within the ruling political elite and a group of associated

53 "2002 Presidential Address to the Federal Assembly of the Russian Federation." Rossiiskaia Gazeta. No. 71 (2939) from April 19, 2002.

${ }^{54}$ Ibid.

${ }^{55}$ Ibid. 
experts. It looked like the entire civil society was welcomed to join the 'discussion board'. Initially, the reform emphasized economic issues and targeted the business community as the primary beneficiary. Therefore, business institutions actively participated in the process of development the reform program, providing their vision on the subject matter. The Chamber of Commerce and Industry of the Russian Federation even prepared its alternative 'road map' for the reform. Thus, the team that worked on the official documents for this reform within the government, addressed the provided critiques along the way. Several of the major reasons why the earlier attempts of the reform failed were mentioned above, including a lack of transparency and response from civil society. This time, reformers tried to minimize the atmosphere of secrecy, and elaborate such a conception that would reflect expectation of wider layers of society.

Although, this idea of openness and concordance is conventionally accepted as the preferred one, it may easily be overestimated. It is not only that such reforms are instigated by the upper layers of government; "[i]t should immediately be acknowledged that management reform is not usually at the top of the citizenry's list of priorities..." and they "are unlikely to be brimming with concrete proposals for better management..."56

Those parties that participated in the discussions of the proposed reform - public officials, business organizations, and scholars - showed clear signs of ideological adherence to the New Public Management doctrine. ${ }^{57}$ Although there were no clear

\footnotetext{
${ }^{56}$ Christopher Pollitt; Geert Bouckaert. (2004). Public Management Reform: A Comparative Analysis (2nd ed.) Oxford: Oxford University Press., p.31

${ }^{57}$ Logunov, A. (ed) "Administrativnaia reforma v Rossiiskoi Federatsii: osnovnye etapy realizatsii.” in Analiticheskii vestnik Soveta Federatsii No. 22 (310), 2006., Moscow. p. 25
} 
references to it in key reform documents and governmental decisions; the entire process of development of the reform, as well as some key solutions correspond with 'the spirit and the letter' of the NPM paradigm. Initial stages of the reform were based on several documents - presidential decrees and governmental resolutions - that prescribed the legal framework of the reform, its objectives and major activities as well as outlined key governmental bodies responsible for analytical and methodological support of the reform.

The first document - "The federal programme of reforming the state service of the Russian Federation (2003-2005)" (hereafter referred to as the 2002 Programme was approved by Presidential decree in November 2002. ${ }^{58}$ The programme provided critical observation of state of affairs in the sphere of public service and proposed measures that were supposed to contribute to its substantial transformation. However a contextual analysis of the document does not yield any direct references to key features of NPM. Most measures were designed to overcome deficiencies of the national public service that were the results of political destabilization and economic and social degradation of the early post-Soviet period. Among the major objectives of this reform, was the aforementioned revision and fundamental upgrade of the relevant legislation. Substantial attention was paid to the logistical and material support of the public service in order to ensure its proper functioning. Most other objectives of the Programme - such as the improvement of efficiency of human resources management and public accountability reflect the overall trend in the development of public administrations in transitional

${ }^{58}$ See: Decree of the President of the Russian Federation No.1336 of November 19, 2002. "O federalnoi programme "Reformirovanie gosudarstvennoi sluzhby Rossiiskoi Federatsii (2003-2005)"”. 
countries. Some proposed measures could be described even as contradicting to New Public Management. The entire idea of 'administrative rulebooks' that were supposed to clarify, describe and constrain procedural behavior of public officials contradicted the managerial philosophy of operational freedom of bureaucrats. Only one objective mentioned in the Programme indirectly referred to the principles of NPM. This was the idea of the formation of a professional public service on the basis of evaluation and stocktaking of performance indicators of public officials' work.

In addition to the idea of quality assessment based on performance indicators, the Programme made clear references to the integrated nature of reforming state machinery in the country. According to its authors, it would be incorrect to deal with various issues of public administration on a fragmentary basis. Instead, "[r]eforming the public service should be conducted within the framework of conception of balanced development, and it should not consist of single-stage radical transformations of the current public service." 59 Thus, the reform of public service was conceived as one, among other deeply intertwined aspects of the more global project of fundamental transformation of the system of governance in Russia.

Closeness of this document to managerialist ideology was also affirmed by the scholars. A. Obolonskiy for example, assumed that the Programme could be understood as "a serious step forward in the transformation of our traditional model of "state" service into a genuinely public service. ${ }^{\prime 60} \mathrm{He}$ believed that regardless of some opportunistic

${ }^{59}$ Ibid.

${ }^{60}$ Alexander Obolonskii (2009) Gosudarstvennaia sluzhba: kompleksnyi podkhod. Moscow: Delo; 512pp. 
compromises with the conservative attitudes towards the reform, this Programme revived "the spirit of 1997" - the year when the most advanced and progressive plan of reform of public administration was introduced.

The other document that conceptually shaped the reform process was adopted by the government of the Russian Federation in late 2005. It was titled "The Conception of Administrative Reform in 2006-2010". The Conception underwent several revisions. The original version of the Conception was limited to three years - from 2006 till 2008. Later, it was extended until 2010. Initially, the document was designed within the framework of a federal targeted programme (federalnaia tselevaia programma). However later, the status of the reform was significantly transformed to a conception. Administrative reform in the form of a targeted programme would involve creation of a directorate - a special administrative body that would be responsible for the reform implementation. However, this would involve additional budgetary expenditures and thus, the programme was not approved in the end. Instead, the reform of the public administration in the country continued in the form of the conception adopted by the government.

A closer look at the different editions of the Conception reveals that most corrections in the document were about expanding the scope of the reform, not revising it. The design or time-frame of the reform were not changed even during the world economic crisis of 2008-2010. One substantial departure from the initial reform design was however made in the later version of the Conception. The document reflected changes in the structure of federal executive bodies that had already occurred, and needed to be addressed in order to maintain documental accuracy. On September 27, 2007 the 
President added a new type of governmental body - a body of state committees, whose functions included those of ministries, services and agencies.

In most other instances, the later version extended the period and the scope of the reform. Introductions to the Conception further enhanced its liberal and progressive outlook. Thus, the reform added steps for improving control and accountability of the system of government as well as forwarding the customer outlook where applicable. Introductions included the task of instalment of the computer-based vertically integrated system of monitoring of governmental agencies named GAS "Upravlenie". In addition, it was proposed that the goal of development of multifunctional centers of deliveries of governmental and municipal services to citizens. The later version of the conception paid great attention to the principles and mechanisms of office work automation, broadly known as the 'e-government concept'. It was stated in the document that development of internet services must increase citizens' accessibility to state services, as well as improve interaction of receivers and providers of state services.

The later version also extended the term of the second phase of public service reform until 2010. However, it does not follow from the document that this revision was because of difficulties in implementation of the reform in earlier stages, as it was mentioned by some observers. ${ }^{61}$ In addition to the initial six, two new areas of reform were introduced. These areas reflected the new goals discussed above. In the last two years of the second phase, the focus of the reform was pointed at the development of

${ }^{61}$ See for example: Leonid Smorgunov (2008) "Administrativnaia reforma v regionakh: mesto IKT v strategiakh razvitiia." Internet $i$ sovremennoe obshchestvo: Trudy XI Vserossiiskoi Konferentsii. Saint-Petersburg: SPbGU, p.188 
these aspects. Moreover, the reformers proposed some acceleration of the reform, as they decided to expand the agenda of measurements in 2008, by adding new tasks and expanding the agenda proposed in the first version of the conception. The task to begin pilot projects of introducing multifunctional centres was added to the list, as well as one of the cornerstone deteriorating issues of governance in Russia-corruption, which was mentioned for one of the first times in the official documents. The Conception posited "development and approval of programs of resistance to corruption" in governmental bodies on all levels.

The Conception was the logical continuation of the first stage of the reform, and it was expanded on the basis of the results achieved in 2003-05. It concluded that most measures of the previous stage were fulfilled and some had been in the process of implementation. At the same time, it was acknowledged that only a small part of the proposed measures reached the stage of practical implementation; and in some higherpriority areas the reform had not yet begun.

Several clauses of the Conception may be outlined in purely managerial principles, or at least their closest approximations. On its second stage, the reform in general was still concentrated on the measures that would limit ability of the state apparatus to intervene into the economic life of the country. This goal was placed second in the document, and followed by another objective of the improvement of quality and accessibility of state services. Improvement of efficiency of governmental bodies was stated as the third goal of the reform. A closer look at the detailed description of these goals discovers their adherence to the ideology of New Public Management. 
One of the major innovations, which the reform introduced, is the new tradition of performance based management principles. The Conception criticized traditional principles of governance based on directive planning. It was said that the current system was insufficient to achieve the goals of state politics. "It is imperative to organize the implementation of planned policies, maintain constant control over their fulfillment and, if necessary, correct them. ${ }^{, 62}$ As it was also stated in the document that such a system did not exist in Russia, and had to be introduced. The older system was more concentrated on policy design and its legal fulfillment. However it lacked specific methods of calculation and analysis of results from implementation of these policies. The second stage of the reform was aimed at the introduction of all these principles.

Performance based management is an idea that is deeply rooted in the managerial paradigm. It shifts focus (but not completely abandons it) from procedural characteristics of civil service to the resultant aspects of activity of public officials. In its extreme, it was expressed in the formula "let managers manage", which put the results of any policy implementation process at the core.

Several more features of the Conception may be referred to the New Public Management paradigm. Among them, special attention must be paid to the measures to abolish redundant state regulation.

Another innovation is also worth additional discussion, as it refers to the reduction of state apparatus and outsourcing some governmental functions to private

${ }^{62}$ Resolution of the Government of the Russian Federation from October 25, 2005 No. 1789-p. "Kontseptsiia Administrativnoi Reformy v Rossiiskoi Federatsii v 2006-2010 godakh." 
companies. Direct involvement of private enterprises and non-governmental organizations to provision of some state services is a clear and sound indication, of the design of substantial aspects of the reform within the managerialist paradigm. The Conception refers to international experience in applying the mechanisms of outsourcing to public sector organizations. It states that "outsourcing allows the improvement of efficiency of managerial and administrative processes, control expenses more efficiently, improve the quality of services, provide access to new technologies, and reduce capital expenses and administrative staff." ${ }^{, 63}$ As a result, all these measures should reduce budgetary expenses without detrimental effects in the quality of provided services. The introduction of outsourcing was seen as a fundamental feature of the ongoing reform.

Close to outsourcing, but not completely identical to it was the idea of competitive tender procurement. Although procurement through tenders had not been something completely new for the system, it nevertheless was paid special attention due to the inefficiency of its (then) current model. The Conception stressed fundamental deficiencies of the procurement model. The entire logic of the pricing policy was put under question. An idea of using “customers' proposals backed by macroeconomic indicators"64 was largely disregarded. This concept was largely based on previous parameters, and thus, was an impediment for further development as new the parameters were based on the previous ones. Such a system did not "allow the estimating actual demands of the state in goods (works, services) needed for implementation of its

\footnotetext{
63 Ibid.

64 Ibid.
} 
functions". ${ }^{65}$ The conception introduced a road map for the improvement of state procurement that included multiple measures in various spheres: from automation of the process and enforcement of procedural austerity, to making the entire process transparent.

In the end, the Conception provided clear and mainly quantitatively measured indicators of successfulness of the reform. The designers of the reform focused on three major parameters: citizens" satisfaction with public service, the level of "administrative barriers" in business sphere, and Russia's position in the world global governance ranking. All these parameters are determined in easy measurable indicators, and to some extent, this also speaks in favour of the dominance of the managerial paradigm among those who were involved in the reform. In case of citizens' satisfaction, the Conception demanded for a new "method of estimation" that had to be approved in 2006. It referred to the research conducted by the 'Public Opinion' foundation that revealed a very low level of citizens' satisfaction with the public service. Only 14 percent of citizens were satisfied by the quality and accessibility of provided services. The Conception proposed a very ambitious plan of significant improvement in the level of satisfaction up to 70 percent by 2010 .

The degree of the administrative burden on business was also presented as a quantitative parameter. This was measured as a percentage of a company's current earnings. Again, as a reference point, an independent survey conducted by the AllRussian Center for the Study of Public Opinion (VTsIOM) and the Russian Organization for Small and Medium Entrepreneurship ('OPORA'). They estimated the degree of

${ }^{65}$ Ibid 
administrative barriers as 8.5 percent of the company's earnings; and the Conception suggested that this indicator must be lowered up to 3 percent by the end of the second phase of the reform in 2010.

Finally, authors of the Conception suggested the use of the international index of governance, which is developed by the World Bank. Countries of the World are ranked according to this index. The authors also took as the starting point Russia's ranking in 2004, and suggested a substantial improvement to aim for, by 2010. In 2004 Russia's index of governance was 48.1 (out of 100) and the index of quality of state regulations 30.5 (out of 100). According to the Conception, it was planned to improve both indexes to the level of no lower than 70 points each. Finding clear, exact and measurable criteria of performance of public agencies, also, however indirectly, associates the proposed reform with managerial paradigm.

At the conceptual level, the second phase of the administrative reform was the most prolific, as it introduced the majority of the changes; and most of these changes should transform the nature of public service in the country. In 2006-2010 it was expected that the new design of governmental bodies, introduced in 2004, would be complemented by a new functional format. Many innovations proposed in the Conception were quite radical, and embodies a shift from traditional principles of bureaucracy, to a new managerial way of governance. Moreover, adherence of the reformers to the new paradigm was not put in question in the later revisions of the Conception, when, as some critics assumed, the reform entered the stage of substantial traction and resistance to its implementation. 
After the second phase, the reform of public administration has become more focused on particular measures. Yet, it had secured a holistic approach to public sector reforms. In the third (current) phase, the reform focuses on three major aspects: the reduction of administrative barriers, improvement of availability of state and municipal services and fighting corruption. The measures to address these issues were summarized in the form of Conception that was accepted by the Government in June 2011. As it was stated in the document, the four major reforms - public institutions, public service, egovernment, and budgetary - can no longer be treated as separate ones; and as the object of reform must be taken with the entire "governmental sector including all its components - state service, finance, system of governance and informational resources. ${ }^{, 66}$

In the third phase the reform has conceptually returned to its initial goal - easing administrative penetration into the economic life. The government took a remarkable approach towards a reduction of administrative barriers. It stressed deregulation as the major option. Thus, the conception addressed the importance of a reduction of the nomenclature of products that need mandatory certification. The latter should be substituted by a declaration of conformity where possible. This falls into a broader concept of shifting from licensing of various business activities to the principle of notification of the government about commencing certain types of private enterprises. In addition, the conception stressed the importance of further stripping the state of its

\footnotetext{
${ }^{66}$ Resolution of the Government of the Russian Federation No.1021-r of June 10, 2011. "Kontseptsiia snizheniia administrativnykh bar'erov i povysheniia dostupnosti gosudarstvennykh i munitsipalnykh uslug na 2011 - 2013 gody."
} 
regulatory functions by ceding this authority to self-regulated organizations. The other approach refers to further delegation of functions from the federal to regional and municipal levels with mandatory delineation of the zones of authority of each layer of governance.

In terms of the provision of public services, the Conception proposed a rather radical shift from "optimization and regulation of certain governmental and municipal services, to optimization and regulation of complex services based on "vital situations" (e.g. childbirth, property acquisition, starting a business enterprise etc.).. ${ }^{97}$ This idea was supplemented by the project of further development of multifunctional centers that provide services according to the "one window" principle. Although the latter was introduced at the conceptual and practical level during the second phase of the reform, in the current conception it was observed and discussed in much greater detail. Taken together, both these concepts represent the attempt of the reformers to significantly transform the state of affairs in the sphere of provision of public services. A reduction in applicants' monetary and temporal expenses is mentioned among the major objectives of this transformation.

\section{Conclusion}

The chapter emphasized the analytical approach in discussing various doctrines and theories of public policy and administration. This approach outlined their major features and discovers similarities and differences. At the same time, an in-depth deconstruction of the theories prevented a focus on the temporal aspects of emergence,

${ }^{67}$ Ibid. 
ascent, maturity and decline of these theories. Yet, a chronological approach would reveal the fact that there were two major paradigms of governance and bureaucracy in the $20^{\text {th }}$ century; and the older paradigm, following the Kuhn's logic, was replaced by the newer one. This approach emphasizes that the current paradigm has already passed its maturity, and has perhaps entered a stage of decline. Many ideas of New Public Management were already outdated by current political, social and economic processes, when they were being implemented in the reform.

More important is the fact that Russia started its reform at the time of a shift of the paradigm. This also contributed to the complexity and hardships that the reform faced during its implementation. The NPM paradigm, that obviously dominated the concept of reform in Russia, is becoming obsolete. Yet, a variety of new approaches have not yet received enough credentials to completely substitute it. However, they raise important issues of civic engagement, public control and accountability, which are being largely neglected in NPM doctrine due to the focus of the latter on such aspects as costeffectiveness and performance improvement..

The choice of New Public Management as the fundament of the reform in Russia may, therefore, be considered justified. However, the concept does not seem flawless anymore, and the degree of care and control over implementation of its major ideas come at the fore when we speak of the success and failure of the reform.

Theoretical uncertainty, as well as peculiarity of the political process in Russia, put additional demands on the design of the reform. Being accomplished within the managerial paradigm, it nevertheless had to take into account not only institutional complexity of the Russian government but also obvious underdevelopment of the 
institutions of civil society. The latter aspect was completely apprehended and addressed at the earlier stages; and contributed to the first quite considerable deviation from the 'classic' managerial approach. Russian reformers decided to begin the reform from radical changes of institutional composition of the state, expecting to move to functional issues subsequently. Therefore, the implementation stage itself became the challenge for successfulness of the administrative reform in Russia. 


\section{Chapter IV. Implementation of policies: public administration reform}

\section{Introduction: the process of the reform}

More than a decade after the collapse of the Soviet system of governance, and a few unsuccessful attempts to begin the reform in the 1990s; following a serious and theoretically driven preparatory phase, the reform of public administration of the Russian Federation finally commenced in 2004. ${ }^{1}$ The reform had a thoughtful analytical background. Key program documents were based on the earlier developments that were made in the late 1990s. In addition to a pool of experts who worked under the aegis of the Centre for Strategic Development, various interest groups, mainly from the business sphere, were involved in the discussion of the major parameters of the reform. Moreover, business organizations such as the Chamber of Commerce and Industry and the Russian Union of Industrialists and Entrepreneurs proposed their own projects, where they outlined their understandings of the future status and functions of the Russian officialdom. As could be expected, their suggestions were radically market-oriented. Although the final programme of the reform was rather moderate, some ideas, proposed by the business community, were addressed in it. Thus, the implementation phase of the reform began on the basis of a well-developed conceptual platform that met not only

\footnotetext{
${ }^{1}$ Alexander Obolonskii states that the formal beginning of the reform may be dated by November 19, 2002 when President Vladimir Putin signed a Decree No. 1336, which included a Federal Program of reform of public service in 2003-05. There is another opinion however that associates the beginning of the reform with the presidential Decree No. 824 from July 23, 2003 "O merakh po provedeniiu administrativnoi reformy v 20032004." This divergence of opinions is mainly due to the Russian academic tradition of treating reforms of public administration and public service independently. This dissertation, however, amalgamates both reforms - public administration and civil (public) service - into a single object of research.
} 
current theoretical trends, but also addressed aspirations of some targeted groups within the Russian political and business establishment.

The process of the reform that lasted for more than a decade included several separate reform projects that were focused on various aspects of governance. Some of these aspects were so distinct that, initially, the reform of government appeared to be split into several separate federal programs that were quite often recognized and treated independently. Such versatility and a large amount of modernization projects can be explained by the very nature of public administration and its role in political and socioeconomic transformations of the country. As far as the process of the reform is rather cumbersome, it needs systematization that must be performed on the basis of its fundamental objectives. The latter may be derived from the 2003 presidential address to the Federal Assembly, in which Vladimir Putin stated that further progressive development of the country is mainly dependent on successful modernization of its government. ${ }^{2}$ The idea of modernization was conceptualized on the basis of an eclectic approach that accompanied two rather opposite ideologies of public administration discussed in the previous chapter: the bureaucratic and managerial models. In this respect, the path of modernization was focused on three major aspects: 1) reduction of state's penetration into economic processes in the country, 2) improvement of the quality of services provided by the state; and 3) the optimization of internal governance processes in order to reduce expenses and improve performance of the officialdom.

\footnotetext{
${ }^{2}$ Vladimir Putin (2013) Address of the President of the Russian Federation to the Federal Assembly of the Russian Federation. (Online) [URL: http://archive.kremlin.ru/text/appears/2003/05/44623.shtml] (accessed: February 12, 2012).
} 
With respect to these objectives a multitude of different reform projects were proposed and their implementation began. For analytical reasons, these measures can be organized in different clusters using three distinctive methodologies. First of all, all reform measures can be grouped with respect to the definition of the subject of the reform. In this regard we may speak of measures that refer to the improvement of either the internal governmental process, as well as those that involve; or relations between the public administration on the one hand, and various agents (economic, civil etc.) on the other. Secondly, all relevant reforms could be clustered chronologically on the basis of key normative-legal documents that launched a particular phase of the reform. On the basis of this classification, we may define three distinctive phases of the reform: 20032005, 2006-2010, and 2011-2013. Finally, due to the ideological eclecticism of the public administration reform, all measures can be grouped into three categories: managerial (or NPM) measures, the so called (traditional) bureaucratic measures and specific measures that address the need to introduce new principles of governance, based on the development of information technologies. These classifications will be given more description in the following paragraphs.

As a fundamental program of restructuring of the Russian system of governance, the project of administrative reform included two major dimensions - external and internal. The external dimension refers to the need for a rapid modernization of economic and social life in the country and, thus, a reconsideration of the role of governmental institutions in these processes. The internal dimension relates to the internal structural problems and functional disparities of Russian officialdom, and focuses on the optimization of administrative processes within it. The external dimension refers to such 
measures that improve development of political, economic and social processes in the country by limiting the state's penetration into the economy, and a reduction of its excessive regulatory functions, as well as an improvement of the quality of services provided to the populace, as well as economic and non-governmental organizations. The internal dimension includes such aspects as the introduction of administrative regulations (or, in reverse, deeper regulation of processes within the state apparatus, within and between public institutions), limitation of excessive and redundant functions of the state, as well as a shift from directive (commanding) to performance-based principles of management, including the shift from ad-hoc and nomenclatural to performance budgeting; and introduction of the merit-based principles of governance. With respect to public services, the reform was aimed at the introduction of explicit nomenclature of norms and firm standards of quality of services provided by the state as well as the enhancement of control over services provided by private agencies on behalf of the state. In this case special attention was paid to the creation of multi-functional centres that adopted the technology of providing public services based on the principle of "single window arrangements", and focused on procedural simplification of servicing citizens.

Although being logically coherent, this approach comprises several issues that cannot be implicitly included into either of the dimensions. Among them, special attention must be granted to the problem of corruption that has been very important challenge for high-quality public service.

The next approach is the chronological one, so the process would be considered as a sequence of stages (or phases). Each stage implied a series of measures in the sphere of modernization of public institutions and in regards to public service and human resources 
management. There are three quite easily distinguishable stages of the reform. Each stage accomplished a particular task in the general plan of reform and was conveyed on the basis of a particular scenario. Each preceding stage is based on the previous one, thus supporting the thesis of continuity and integrity of the reform process. The general program of reform, although never being written in the form of a single document, implicates three key documents, one for each stage, that provide very exact time periods within which every stage must be conducted and accomplished.

As of 2013 the reform of public administration has undergone two consecutive phases (or stages) and currently is at the end of the third stage. There is little evidence regarding whether the current stage will be the last one, however. The first stage of the reform covered actions undertaken in 2003-2005. It was regulated by the Decree of the President "On the measures for conducting of the reform of public administration in 2003-2004". The second stage took place in 2006-2010; it was followed by the current stage that has been scheduled to be accomplished by the end of 2013. The first stage aggregated mainly the preparatory measures. During this stage the ideology and objectives of the reform, as well as its major stages and actions were finally developed and approved. The stage was culminated by the fundamental structural transformation of the Russian government and installment of the three-layer system of public administration.

The second stage was initially planned for three years: from 2006 and until the end of 2008. However, due to officially unexplained reasons, the stage was extended until the end of 2010. According to the idea of the reformers, the second phase of the reform should become the main one, during which the proposed structure of government would 
be given qualitatively different content. During this phase, the entire spectrum of reforms should be implemented — internal as well as external —in order to advance the entire system of governance. For the second, as well as for the third stages special conceptions were developed. These conceptions not only established the exact time frame for the various reforms; they also provided a more holistic outlook of the process of reform. Conceptions included a thorough theoretical background of the reform that broadly described the objectives of the reform and defined the desired ideal type of future public service. In addition, they provided detailed, step-by-step plans of necessary measures that must be conducted at each stage. These were measures in the sphere of public institutions as well as related to the national bureaucracy.

The third stage of the reform began in 2011 and is scheduled to be accomplished by the end of 2013. Its major agenda reflects the need to finalize the reform in all its aspects; and in this regard, the third phase is the logical extension of the previous one. However, two major characteristics make it distinctive. First of all, during this phase, the reform process received a rather unexpected boost. The specifically prepared Conception provided a scrupulously detailed and very technocratic plan of reforms. Secondly, there could be indicated a shift of the focus of the reform: if at the earlier stages, economic development dominated the agenda, then in the course of the current phase, it has become apparent that the major attention now is being paid to the issues of the improvement of the provision of public services.

The third and final classification groups the reform efforts according to their ideological background. As it has already been stated, the Russian project of modernization of public administration is eclectic and gathers insights from both 
traditional and managerial paradigms of governance. Thereby, all governance reforms, performed in Russia since 2003 can be split into three distinctive groups. The first one would include all actions that come under the aegis of the New Public Management paradigm. Such reforms are aimed at the improvement of efficiency by means of adoption of new technologies of governance, mainly aimed at reduction of bureaucratic traction in provision of public services (such as performance-based budgeting and meritbased personnel stimulation). Here we also speak of such measures as a 'single-window' approach and establishment of the multi-functional centers of public services provision.

The traditional cluster, in reverse, emphasizes measures aimed at improving regulation of activities of public agencies and public officials, providing procedural consistency, and setting up optimal deadlines for public officials to perform their duties. It also includes actions aimed at the improvement of social status and security of employees of governance institutions. In the core of this cluster lie reform actions focused on the introduction and promotion of administrative regulations - specialized codes that prescribe necessary, as well as sufficient procedures needed to be performed by public officials in order to fulfill a particular state function or provide a public service.

There is a third group of measures that must be given a distinctive outlook in this chapter due to their importance for the entire reform process. It cannot be included in either of the two previously mentioned categories due to its distinctive and simultaneously overlapping nature. It includes specific improvements of the process of governance on the basis of universal application of achievements in contemporary information technologies. Computerization and expansion of internet-based technologies significantly changed the essence of contemporary governmental processes world-wide. 
Therefore, any $21^{\text {st }}$ century reform must, in one way or another, address opportunities created by the IT-revolution. In the earlier stages of the reform, the technological cluster was focused on measures aimed at the improvement of structural capacity of public administration to accommodate the creation and development of the e-government concept.

The ideology of the reform imbibed substantial innovations of the concept of New Public Management. However, like in some other cases, the actual program of the reform included several important deviations from the so-called 'classical' or 'ideal' model of NPM. Indeed, the quite radical program of managerial reforms that was implemented in exemplary countries like New Zealand, Australia, and the UK, needed considerable adaptation to Russian realities. As discussed earlier, Russia was recognized as a "lowtraction country"3, which shows significant drawbacks in its system of governance, has a complicated structure of institutions of state, as well as a peculiar political tradition, partially inherited from the Soviet period. As the first post-Soviet decade revealed, the transition paradigm that implied direct replication of models and principles of governance, based on the successful experience of developed countries, had not justified expectations. Therefore, despite the fact that the general managerial trend in public governance reform in Russia may nevertheless be justified, actual steps and actions have to be carefully and deliberately selected.

Analyzing the process of implementation of the reform in Russia it can be observed that some of the deviations from the benchmarks of conducting of public administration reforms were deliberate and intentional. Yet some other changes were not

\footnotetext{
${ }^{3}$ Nick Manning, Neil Parison (2004). International Public Administration Reform: Implications for the Russian Federation. Washington: World Bank.
} 
expected by the reformers. If the deliberate changes were made in order to address specificities of Russian officialdom, the unplanned ones could be merely responses of the bureaucratic system to the changes imposed on it. Obviously, the very process of the reform itself has been the factor that affected the way the prescribed objectives were achieved and, thus, must be taken into consideration. In these circumstances the case of the officialdom is even more substantial given the complexity of the subject-object characteristics of the reforms, where the bureaucracy not only is the primary object, but also the immediate conductor, or the subject, of the reform.

As it was discussed in the Introduction, The Russian tradition separates the reforms of public administration and civil service. At the same time the reform of public service, altogether, with the reform of public administration, should be named as another substantial part of a larger project of modernization of the system of governance in Russia. Yet, at the same time, complexity and multifariousness of the topic of research allowed some scholars to consider the reform of the public service as a specific and independent object of scientific inquiry. This trend was reinforced by the fact that in their earlier stages, both public administration and public service reforms were developed separately from each other by independent groups of experts. Moreover during their earlier stages the reforms were conducted rather independently from each other.

Analysis of the process of implementation of both reforms at every stage is aimed at revealing any potential deviations from the initial design, and the delays that led to them. To achieve this goal the most efficient method would be to analyze independently the modernization efforts in the sphere of public institutions as well as public service. Methodologically, such separation would be reasonable as far as the objects of both 
reforms differ substantially. The former (administrative) reform is aimed at a transformation of the structural composition of the country's governmental institutions in order to improve the governance capacity of the public sector. At the same time, the latter reform is aimed at the improvement of process-based aspects of governance, or in other words, at building a knowledgeable, effective, responsive and mobile public service capable of working within the proposed structural configuration with maximum efficiency. At the same time, it must be stated that both administrative and bureaucratic aspects of the reform of public administration are considered crucial for a holistic approach to the investigation of complications and inconsistencies of modernization of governance in Russia.

Consequently, Chapter 4 is devoted to the study of the process of modernization of governmental institutions. The reform of public service will be assessed in the following chapter. The research hypothesis states that the very process of reform may be among the crucial factors that contributed to complications of the modernization project. In the following pages, not only will the major actions, performed in the process of reform, be scrutinized; the most important results of the modernization efforts will be assessed here as well. A discussion on the implementation of the reform of public administration will include an analysis of all its three major stages. These stages will be presented chronologically, and most significant innovations that were introduced at the time of their implementation will be described. The description will be followed by an assessment of success of these measures and analysis of the factors that could contribute to deviations from the proposed objectives. As far as each phase of the reform of public administration includes various measures, the latter will be clustered according to their 
ideological background. Therefore, each phase will include a description and critical assessment of the reform measures undertaken within the managerial, classical bureaucratic, or technological paradigms.

\section{Institutional reforms in the sphere of public administration}

\section{First phase of the reform: 2003-2005}

The idea of modernizing the system of public administration in Russia was becoming more and more sound, since the first remarks of the President, until its formal launch in 2003. Stabilization of the political situation in the country, significant improvements of the federal authorities in establishing of the 'vertical of power', as well as favourable economic conditions - constantly improving since the 1998 financial crisis - allowed the ruling political elite to penetrate into one of the most complicated spheres of the political process - the bureaucratic apparatus.

The reform of public administration, or to be exact, the reform of the institutional aspect of governance began in July 23, 2003, when President Vladimir Putin issued Decree No.824 "On the measures for conducting the administrative reform in 20032004." This was the first official document that actually provided a plan of action and prescribed steps that must be made in order to bring changes to Russian government institutions. This document is important for the entire decade-long process of the reform, as it affirmed the major goals and key aspects of the reform and established its organizational framework.

It was stated in Decree No.824 that the top priority of the reform would be the rearrangement of the government's role in respect to the economic life of the country. From the beginning of the reform, the economic aspect was granted major attention. 
Three out of five major aspects of the proposed reform were related to this issue. The major objective of the reform was named the "limitation of state penetration into the economic activity of business enterprises, including liquidation of excessive regulation."4 Among the related objectives, another deregulatory action was mentioned, namely the development of self-regulated organizations in the economic sphere, as well as the "organizational division of functions pertinent to regulation of economic activities, supervision and control, management of state property..."5

Although modernization of public administration was mainly targeted at the economic and business community, it nevertheless was not completely one-sided. In addition to the major goals the outlined reforms to eliminate internal administrative deficiencies, such as duplicating and superfluous administrative functions. The Decree also addressed the need to extend the established 'power vertical' model of federative relations to the regional level by delimiting authorities between the two levels. The first decade of post-Soviet development was marked by gradual, or even incremental transformation of the system of bureaucracy that resulted in functional inconsistencies and duplications. The need to liquidate all duplicating functions was addressed in the document as one of the top priorities. Avoiding functional overlap between the regional institutions of public service and the regional branches of subsequent federal institutions of the public service is one of the most important tasks of any public administration reforms in federative states; and it was presented in the Russian project as well. The Decree also posited that a special Governmental Commission be established, whose goal

\footnotetext{
${ }^{4}$ Decree of the President of the Russian Federation No. 824 of July 23, 2003 "O merakh po provedeniiu administrativnoi reformy v 2003 - 2004 godakh"

${ }^{5}$ Ibid.
} 
would be management and oversight over the process of reform. The Commission included specialists from all types of executive branches: from the presidential administration and federal ministries, to regional and municipal executives. The structure and activity of the Commission were formalized by a specific normative act. Also, the prime-minister was made responsible for the quarterly reports to the president on the progress of the reform.

The Commission must have an intra-departmental structure and include representatives from the Presidential Administration, federal ministries, regional and even local self-governments. Therefore, during the earlier phases the reform was understood mainly as an internal bureaucratic (or administrative) matter. Regardless of its pro-business modernization agenda, the economic community was primarily perceived as a customer and beneficiary from the reform, not as a participant in it. Earlier compositions of the commission did not include members from economic community or civil society. ${ }^{6}$

For the first time in post-Soviet history, intentions and even the preparation of the reform of public administration were processed through the layers of the bureaucratic apparatus and reached the stage of practical implementation. Thus, presidential Decree No.824 was a significant step forward in addressing issues of governance in practice. Yet, the document was rather vague in terms of mechanisms and policies that needed to be conducted in order to achieve the desired goals.

One of the distinctive characteristics of the reform in the Russian Federation was the fact that it began with institutional transformations of the central state apparatus.

\footnotetext{
${ }^{6}$ This, however, has been changed later and contemporary commission includes members of influential business associations and academic organizations.
} 
Whereas the Decree No.824 was focused on the conceptual and organizational issues of the reform, its practical phase began in 2004, when President Vladimir Putin issued a Decree No.314 'On the system and structure of organs of executive power'. This Decree introduced a three-layer system of public service: ministries, services and agencies.

According to this system, federal ministries are designed to issue policies and regulations in the spheres of their authority. At the same time, ministries are bereft of functions of control and management of state property. Federal services execute functions of control and inspectorate in specific spheres. At the same time, they are exempted from exercising functions of policy issuance and property management. The final cluster of governmental bodies - federal agencies - is designed to provide services to the public and execute functions of management of state property. Such a system of public administration allows the separation of three major functions of public governance. The first function-development of state policies-deals with strategic planning of the patterns of further development of the state in specific spheres of public life. The second function - that of supervision and inspectorate - is aimed at securing law and order, as well as regulation of various types of public activities within the territory of the country. Finally, the third function deals with the provision of essential public goods and services that have become one of the distinguishing features of a welfare model of state.

That established a conceptually new system of organization of administrative processes at the federal level. This system was to become the backbone for further transition from the Soviet-style departmental model of government, to the modern, functional system. Unlike the former model, based on the sectoral control of economic and social activities in the country, the latter one is focused on particular 'publicly 
significant' functions that can only be performed by the state. Therefore, in terms of the organizational capacity, the cumbersome bureaucratic government must be substituted by the more mobile, compact and responsive public administration. From the beginning, the reformers put an emphasis on the structural aspect of governance, expecting that the proper institutional arrangement would be further filled with necessary content. However, this ultimately raises two research questions: 1) why the reformers preferred structural changes over modernisation of the functional capacity and improvement of performance of the already existing system of governmental institutions; and 2) what would be the nature of 'vertical' (e.g. ministries-services-agencies) and 'horizontal' (ministry-ministry, agency-agency etc.) relations?

Such an approach, which stressed the 'top-to-the-bottom' vector of conducting reforms, was a substantial deviation from the ways administrative reforms was performed in other countries. Imposing the new, three-layer structure of the government "from the top" the ruling elite demonstrated its willingness to begin the reform without waiting for initiatives from the bureaucracy, or articulated demands from civil society or pressure groups. As it was stated elsewhere:

As a result of the theoretical research... [is that] its implementers chose the ideology of 'denationalization of power'. It included the following scheme of conducting the reform. Initially, generally acknowledged (or imposed "from the top") perceptions about the goals ("final objectives" of the activities) of the state are being formed in the society... After that, higher executive institutions transfer parts of their authorities... to autonomous agencies... Finally, all public officials employed by these agencies become identical to the employees of separate firms, which product is standardized public services.

\footnotetext{
${ }^{7}$ A. Logunov (ed.) (2006). "Administrativnaia reforma v Rossiiskoi Federatsii: osnovnye etapy realizatsii". Analytical Bulletin of the Federation Council of the Russian Federation. Ser.: Problems of State-Building No. 22(310), p. 29.
} 
The second question raises an important problem of the transition from the sectoral to functional principles of governance - an issue that lies at the core of the institutional modernization of the system of governance in Russia. The approach to rationalize the structure of the federal executive bodies was a significant step forward, as it definitely reduced the Soviet-type bureaucratic burden, the distinguishing feature of which was excessive departmentalism. The latter was expressed not only in the form of creation of a multitude of public agencies, but also by the lack of communication between them. The Soviet governance style, which was signified by almost total bureaucratic control over the economic sphere, demanded the existence of special departments that governed and controlled particular spheres of the economy and public life. Literally, every economic sphere had a corresponding governmental agency. Since the collapse of the Soviet Union, many ministries were considered obsolete and were liquidated. Yet, some remnants, like Ministry of Railways, were still active.

The approach presented in the official documents was not as radical as propositions developed within the business community. Such business associations as the Russian Union of Industrialists and Entrepreneurs and Chamber of Trade and Commerce of the Russian Federation proposed a rather radical set of measures that suggested complete abolition of the departmental principle, or the form of bureaucratic control of a particular sphere of economic life by means of creating a specific public agency. ${ }^{8}$ Should it have been accepted, this idea would have radically reduced the number of top-tier executive offices (e.g. ministries) from twenty two to seven. Such logic implied that the remaining ministers would focus on those functions that by default can only be

${ }^{8}$ See for example: Alexander Bekker (2003). "Piat' urovnei Shokhina. V RSPP pridumali reform pravitel'stva." Vedomosti. No.55 (April 1). 
accomplished by the state. The document outlined exclusive prerogatives of the state in forming national strategies in the following areas: national defense, internal and foreign affairs, economy, finances, justice and social politics. It must be admitted that such a reduction was rather radical by all possible standards. Even countries that are considered to be in the avant-garde of the so-called 'shrinking the state' movement, such as New Zealand, Australia, and the United Kingdom, have a considerably larger nomenclature of ministries and other agencies in their governments.

The actual plan of the administrative reform, prepared by the governmental commission, was not so radical. Moreover, in reality it did not contain the intention to abolish existing ministries and radically cut down the number of functions that they perform. However, it was planned that some ministries would merge with others, without eliminating the key functions of either. At the same time there were such issues that both plans had in common. One of the commonalities was the idea of the separation of political and administrative functions of the government. Moreover, the separation had to be performed at the level of institutions. This idea was fully presented in presidential Decree No.314.

The Decree established five distinct clusters of functions of contemporary Russian federal government. The first function refers to the development of state political and legal regulations in a particular sphere of social or economic life of the country. Control and inspectorate of activities of individuals, economic and social actors are put in the core of the second function. The law enforcement function is also included into the second cluster, however the document pointed out its distinctiveness from the other two. The third cluster included governmental activities in the sphere of running various 
cadastres and registers, as well as the issuance of individual regulations in particular situations. Management of state property and provision of state services to citizens and economic agents constituted respectively, the fourth and the fifth clusters of governmental functions.

The first function, that of 'rule-making' and legislative activities, may be distinguished from the other four by its nature. The establishment of the future course of the country by means of development and implementation of policies is undoubtedly one of the most fundamental functions of the institution of government. It also involves regulation of activities of various actors in order to achieve the desired goals in particular spheres of the country's life.

The other four functions of the government can be regarded as purely administrative and related, in one way or another, to the fulfilment of these policies. However, these administrative functions are not conceptually identical. Administrative functions could be separated into two groups. The first group incorporates functions of inspectorate and control. Broadly speaking, these functions include activities aimed at the proper fulfilment of existing legislation by all social, economic and political actors, as well as ensuring stability and security of the country. The second group includes administrative functions of the provision of services and management of state property. This group constitutes the welfare component of the contemporary state and literally connects the government with other spheres of public life. A contemporary government not only establishes regulations and enforces their fulfilment on the territory of the state; it also provides services and performs economic activities in particular spheres. 
The introduction of the typology of functions was a definite step forward in the development of post-Soviet public administration in Russia. Prior to the Decree No.314, no classification of the functions of government existed. The aforementioned five clusters of functions were considered by the reformers as essential government activities that could not be abandoned, or responsibility for their fulfilment could not be transferred to either economic organizations, or civil society. These functional peculiarities of contemporary public administration were fully recognized by the reformers and addressed in presidential Decree No.314. It was understood that in order to improve efficiency of the government, it was important to separate on the level of public institutions not only political and administrative functions, but also two groups within the block of administrative functions. The distinctiveness of the aforementioned clusters of governmental functions, prescribed the differences in the approaches to the formulation of both organizational structure and cadre politics in the sphere of public administration.

The emphasis on functional capacity of the federative executive bodies was the cornerstone feature of the entire reform. As some experts who were directly involved in the process of designing the reform, mentioned, this approach would "finally allow to bring to an end the 'infinite' [process of] reorganization of the state apparatus, [and] rationally reorganize the principle of 'three definitions' tested for centuries: 'functions, structure, staff". "The idea of this triad refers to the prevalence of the functional approach in public administration that implies creation of organizational structures and staffing them only in those situations where fulfilment of a particular function was recognized as imperative. Therefore, at least at the earliest stages of the reform and in the

\footnotetext{
${ }^{9}$ Sergei Naryshkin, Tatiana Khabrieva (eds.) (2006) Administrativnaia reforma $v$ Rossii, Moscow: Infra-M. p.18
} 
key program documents, the impetus to transform the public administration according to the functional principle was obvious. Thus, the Decree No. 314 begins with a description of functions of the government, and only after that, the new system of federal public institutions is introduced.

In order to address these issues a three-layer system of institutions of federal government was introduced. The declared goal of such functional specification was "to exclude collisions among functions of policy elaboration, policy making and control over state policies." ${ }^{10}$ It was decided that federal ministries would fulfill political functions, federal services would be commissioned to perform controlling and inspectorate functions, and federal agencies would take responsibility for services provision, state property management and running cadastres and registers. Therefore, the newly established federal system of governance in Russia stressed three distinctive spheres of governance: policy creation, state control, and services provision. The established threelayer structure of the federal public administration is still in place, and regardless of the introduction of some rather crucial transformations, it still determines the contemporary modus operandi of the executive branch.

It is imperative to discuss the assumptions for such a thorough structural modeling. The introduction of separation of political and administrative functions is a very important feature of the analysis of transitions performed by the former socialist countries in the sphere of public administration. This feature lies behind theoretical discrepancies between the major ideologies in the sphere of public administration. Separation of political and administrative functions is widely accepted by adherents of

${ }^{10}$ Ibid., p.40 
both the New Public Management and (Neo-)Weberian (neo-bureaucratic) approaches. This feature rather signifies the differences between the socialist and market-oriented public administrations.

However, although political-administrative separation is considered imperative for contemporary approaches to governance, there are ideological differences in justifying the existence of this principle. Adherents of the bureaucratic approach emphasize the political accountability aspect, whereas 'managerialists' focus on the economic efficiency. The bureaucratic model posits that the corpus of professional public officials who exercise "the power of expertise ${ }^{11}$ must be exempted from performing political functions due to accountability issues. Instead, their activities must be prescribed in specific codes and they must perform only the administrative functions of soliciting elected politicians in conducting policies efficiently. The managerial approach on the other hand, emphasizes the necessity to deregulate activities of public officials in order to 'let them manage'. As it is stated, political efficiency is conceptually different from administrative efficiency. Therefore, these two spheres must be treated rather separately. Regardless of existing ideological differences, both approaches acknowledge the supremacy of political functions over administrative ones, and the need for subordination, however limited, of the latter to the former ones. ${ }^{12}$ It must be acknowledged that

${ }^{11}$ This is a common approach, to consider that the expertise of bureaucrats in particular aspects of governance gives them policy-making power. See: Edward C. Page, (2012). Policy without politicians: bureaucratic influence in comparative perspective. Oxford: Oxford University Press.

${ }^{12}$ It must be stated that most theoretical explanations are based on the Westminster political model, in which elected officials form governments and take control over ministries. In this situation, the political-administrative dichotomy is constitutionally embedded. In case of presidential systems, this dichotomy is more complex and the functional aspect comes to the fore. 
subordination is considered in conjunction with performance-based accountability of public officials to elected politicians. Therefore it secures managerial flexibility and provides operational freedom for officials to perform their duties.

The political-administrative dichotomy was addressed in the Russian case as well. However, it was done at the institutional (or structural), not functional level. In other words, the established three-layer system separated function among three distinct types of public institutions in such a way that one type of function cannot be assigned to different types of institutions. It was also planned that federal services and agencies will be granted operational independence from the various ministries.

At the same time, unlike in the classical Weberian model where the function of policy creation corresponds with the elected public positions, in the Russian case, a specific set of institutions - namely federal ministries - was granted this option. On the conceptual level, it was a very important step, as the ministries should be given a considerably reduced ability to control their subordinate services, inspectorates and agencies. In theory, this control cannot be extended beyond the formalized parameters of accountability.

The reform outlined the federal ministries vis-à-vis the two other types of institutions-federal departments and agencies-because they perform political functions. Furthermore, federal agencies were also distinguished from federal ministries and services by the nature of the functions they are designed to perform. Fulfilment of the service provision function, with an emphasis on efficiency and enhanced quality, implies sufficient operational freedom for public officials. In accordance with the managerial approach, those public officials who are entitled to provide services to the population, 
should not be bound by strict rules and carefully written procedures - factors which are imperative for the functions of control and inspectorate, and also important for policy making. This does not imply however, that no rules should be provided. Rules should instead be made in a way that they promote efficiency. In this respect, the modus operandi of the employees of the federal agencies differs substantially from that of officials employed by federal ministries or services. Imposing managerial ideology into the sphere of governance necessarily results in the adoption of the principles and methods of management developed in a competitive business environment. The 'let managers manage' approach cannot be successfully implemented if it is not accompanied by specific, business-like features of the accountability as a method of performance management. Services and inspectorates, and to a lesser extent ministries, should inculcate a different administrative culture of strict following the rules.

This approach also demands the introduction of the new principles of remuneration for public officials. As far as the ultimate goal of federal ministries' employees is to develop and issue political decisions, their salary must be the highest among public officials in order to provide proper incentives for them to perform their duties in a satisfactory fashion. Sufficient remuneration would allow the avoidance of potential conflicts of interests and mitigate corruption. The fact that there does not exist the possibility to easily measure the quality of work of ministerial employees also speaks in favour of this approach. Quite similar reasoning may be provided in the case of federal services' employees. Yet their efficiency may be monitored on the basis of strictly following rules and procedures, as well as the reduction of errors and other deviations from the provided regulations. Such an assessment creates a basis for providing 
bonuses. ${ }^{13}$ The situation turns out to be rather opposite in the case of federal agencies. In accordance with the new public management doctrine, agencies should thus compete with each other regarding the issues of allocating scarce budgetary resources; they must also provide services or manage state owned economic assets with maximum efficiency. As business practices show, such a working ethos is very well supported by awarding bonuses to the most efficient and advanced institutions and employees. According to this logic, the base salary of employees working for the federal agencies should be lower than that of their colleagues in other institutions; and the bonus part of remuneration should be necessarily provided.

The three-layer system of public administration appears to be a theoretically driven, yet eclectic concept, as it inherits principles of organization of public institutions pertinent to different theoretical models. However, the very nature of the state and the political regime in Russia affect the structural-functional composition of the government. The super-presidential political regime prioritises the executive branch of power over the other ones. Constitutionally, the president, as the head of state, de-jure controls the entire officialdom through the prime minister. The Decree No.314 complicated the situation. As a result of the reform within the federal government two specific zones of authority were created. The president took direct control over some ministries, services and agencies, whose functions may be described as political (see Appendix III). At the same time, the government itself, under the chairmanship of the prime-minister, was commissioned to solve economic and social problems.

\footnotetext{
${ }^{13}$ Yet, this is purely optional and cannot be stated as the basic rule.
} 
In theory, the separation of governmental functions between offices controlled by the president and offices controlled by the government apparatus, should not affect the principles of structural-functional heterogeneity embedded into the three-layer system of government. Ideally, only political agencies could issue normative regulations in the sphere of their authority; services are designed to invigilate proper implementation of these regulations, as well as general legislation; and agencies would provide services and manage state-owned property. In practice however, it begot blurring the boundaries between ministries and services, as the latter ones were also given the right to issue normative regulations within their exclusive zones of authority. As one of experts points out, "a specific feature of the federative institutions of executive power... is that almost all of them are granted functions of normative-legal regulation."

The introduced three-layer governance system, at least in principle, matched the governmental structure in those countries, where the New Public Management doctrine was rather influential. The separation of political functions from administrative ones and the enhancement of client orientation, especially in the sphere of the provision of state services, is one of the most common institutional features of NPM. In this regard systemic changes in the Russian government, introduced by Decree No. 314, followed the world-wide trend in reforming national public administrations.

The new system of government also introduced an important political paradox. It emphasized the functional aspect of public administration, yet institutionally the system resembled the structure of the government that existed prior to the introduced changes. In other words, the overwhelming majority of institutions of the federal government

\footnotetext{
${ }^{14}$ Iulii Nisnevich (2008). "Administrativnaia reforma: tseli i rezul'taty." Bulletin of the Peoples' Friendship University. Ser.:Political Science, No. 4., p.14.
} 
remained the same after the adoption of the presidential Decree No.314. At the same time, the fundamental feature of public administration prior to the reform was the hierarchical, 'top-down' principle of organization of the administrative process. The ministry (or in particular cases the state committee) was made responsible for the entire sector of political, social, or economic development of the country. In this regard other institutions of the government were made subordinate to the ministry in most important aspects such as planning and budgeting. The minister was granted the ability to exercise power to issue direct orders to organizations under his subjection. Thus, the office of the minister, directly or indirectly exercised, control over various functions, from rulemaking to control or state property management. Therefore, the previously existed hierarchical principle was retained in the new three-layer system of federal government.

The three-layer system, at least de-jure, declared a separation of functions, limiting each type of government institution to only one particular type of functions. Moreover, Decree No.314 stated the impossibility for ministries to perform functions of control and inspectorate, as well as to manage state property and provide public services; services could not participate in policy-making; and agencies were strictly limited to property management and provision of services. In such a situation, ministries had to lose some important functions that they had previously possessed. Obviously, as was stated earlier, this initiative affected the policy making process and faced resistance from the ministerial corpus. As President Putin stated, this idea of separation "had not worked as it was expected... [because] ministers continued to pull the administrative blanket towards 
themselves." ${ }^{15}$ During 2007-2008, the principle of structural-functional diversification was further compromised, but at this time only at the institutional level. Presidential Decree No.1274 from September 24, 2007 "Regarding the structure of the federal organs of executive power" reinstated state committees - a particular form of public institutions that existed prior to the reform. These committees were given all three types of functions. Section four of the Decree stated that "the state committee... fulfills functions of elaboration of state policies and normative and legal regulation, control, inspectorate as well as the provision of public services and management of state property." ${ }^{\prime 6}$ Thus, in the case of state committees, the entire nomenclature of state functions was concentrated in a single institution. Although only two state committees were created ${ }^{17}$ before they were again abandoned, the precedent itself was rather remarkable and symbolic. It revealed that the idea of the vertical control in the sphere of governance had never been abandoned and that the older principles of ministerial control remained persistent to a certain degree.

As a result of institutional transformations, public administration in Russia did not follow the general managerial trend of separation of political and administrative functions of government, such as for example in the United Kingdom, where "the system of traditional ministerial governance was transformed into a network of governing ministerial centres that interact on a contractual basis with 140 newly created — and made

\footnotetext{
${ }^{15}$ See: Dmitrii Butrin. "Vladimir Putin raspredeliaet odeiala.” Kommersant, №25 (3842), 15.02.2008.

${ }^{16}$ Decree of the President of the Russian Federation No.1274 of September 24, 2007 "Voprosy struktury federal'nykh organov ispolnitel'noi vlasti"

${ }^{17}$ These two committees were: The State Committee for Youth Affairs, and The State Committee for Fishery.
} 
accountable to the parliament—public agencies." ${ }^{\text {18 }}$ The architecture of the Russian federal government after it underwent institutional modernization, resembled a network of hierarchically subordinated administrative units, where federal ministries, the apparatus of the government, or the president, exercised control over federal services and/or agencies. Besides, the very status of Decree No.314 itself, which resembled a lot of features of the highly criticised 'framework laws' ${ }^{19}$ (ramochnye zakony), further complicated the situation by providing the controlling organs with the right to issue normative-legal documents in exceptional cases. Unlike in the United Kingdom, those institutions of the Russian federal government that are designed to perform administrative functions were not freed from the ministerial political-administrative control. Such freedom is one of the most fundamental features of successful adoption of New Public Management principles of government.

The first stage of the administrative reform was predominantly, but not exclusively, limited to harmonizing the nomenclature of state function, primarily by means of classifying and assigning these functions to the three distinct types of governmental institutions. In addition, the functional capacity of the government was revisited. Since passing the Decree No.829, "On measures of conducting the administrative reform in 2003-2004", this process was, as noted above, put under the control of the special interdepartmental commission. As a result of such fundamental stock-taking, more than five thousand state functions were revealed. Among them, at

\footnotetext{
${ }^{18}$ V. Leksin et.al. (2006). Administrativnaia reforma v Rossiiskoi Federatsii. Normativnaia baza, problemy realizatsii, rekomendatsii. ARCADIS BMB / GOPA / VNG International / ILPP., p. 3

${ }^{19}$ Peter Solomon (2008) "Law in Public Administration: How Russia Differs" Journal of Communist Studies and Transition Politics, Vol.24, No.1, p. 119
} 
least a quarter of these functions were recognized as redundant and approximately additional five percent were duplicating. In addition, the commission also revealed that approximately 800 functions needed to be changed. Therefore, more than one third of the functions demanded some sort of transformation, revealing that the model of governance that had existed in Russia during the first post-Soviet decade was inefficient and encumbered.

The initial stage of the reform of public administration may be affirmatively named preparatory. From the beginning, reformers adopted a technocratic and rather practical approach to the modernization of public administration, which significantly affected the implementation process, as well as future outcomes of the reform. The technocratic nature of the reform can be explained by the procedural flexibility in addition to its rather firm ideological orientation on the major postulates of the New Public Management paradigm. The technocratic approach to the planning of the reform was based on the primary focus on the final objectives of the reform, i.e. the future vision of Russian public administration. Yet, the reformers had to take account somehow of the enhancement of the vertical vector of the political process in the country. Thus, the reform project was marked by an eclectic adoption of different measures, which as was explained, addressed cultural and behavioural peculiarities of the Russian political tradition. During the first stage of the reform procedural flexibility revealed itself in the fact that in order to reconcile the reform with the 'power vertical' reformers had to begin with the institutional transformations of the federal government instead of focusing on ensuring the division of political and administrative functions of the government or 
promoting managerial administrative practices on the lower levels of the bureaucratic hierarchy.

Such flexibility of the structural reform process resulted in incompleteness of the process of institutional separation of state functions and did not produce the desired results. This point of view is supported by some experts, who argue that "because in Russia the structural reform outstripped the functional one... it is unlikely that there will be an increase of efficiency of the state apparatus in the nearest future." ${ }^{20}$ They also suggest that "in governance not structural but functional issues dominate." 21

The process of optimizing the nomenclature of state functions also became an object of criticism. The entire process of selection of excessive or duplicating governmental functions, which was ultimately based on reformers' subjective conclusions, was ostracised, as it "contributed to confusion and chaos" in this sphere. ${ }^{22}$ According to the logic of the technocratic approach to revision of functions of government, each function was by default presumed to be excessive. It was the process of examination and collegial approval that the reinstated importance of these functions. Therefore, the process of revision did not exclude excessive or duplicating functions from the existing pool of functions; it rather created a new nomenclature of state functions on the basis of an opinionated selection process. This approach obviously resulted in multiple revisions of state functions and further complicated the reform process. Moreover, as will be demonstrated in Chapter VI of this dissertation, this feature of the

\footnotetext{
${ }^{20}$ Sergei Naryshkin, Tatiana Khabrieva (eds.) (2006) Administrativnaia reforma $v$ Rossii. Moscow: Infra-M p.49

${ }^{21}$ Ibid.

${ }^{22}$ Viktor Vishniakov (2011). "Administrativnaia Reforma: 15 let poiskov kontseptsii.” Zakonodatel'stvo i Ekonomika, No. 7.
} 
technocratic approach to conducting the reform would have an overall negative impact on the reform.

\section{Second phase of the reform: 2006-2010}

In 2006 the second stage (or phase) of the reform of public administration began. Unlike the earlier stage that consisted of several rather distinct reform projects, which were presented in the form of several presidential Decrees, measures of this stage were presented in the form of a conception. "The Conception of Administrative reform in 2006-2008" (hereafter 2005 Conception) was prepared and legitimized in the form of governmental resolution No. 1789-r from October 25, 2005. Obviously, this downgraded the political value of the document. In symbolic terms, it may be argued that from the second stage, the reform had become strictly an internal matter of the government itself, further escalating the dilemma of the reform that should be implemented by those who ought to be reformed.

Initially, it was planned that the reform would be continued in the form of the Federal Targeted Program (Federal'naia Tselevaia Programma, or FTsP) that was prepared by the Ministry of Economic Development and Trade. It was expected that the program would last for 5 years, from 2005 till 2010, and include all steps necessary to build a modern public administration in the country. A peculiar form of financing was developed for federal programs, which specifically targeted the distribution of federal budget resources, and was the most widespread form of conducting reforms and introducing innovations for particular spheres of economic and social life of the country 
during the entire presidential tenure of Vladimir Putin. ${ }^{23}$ This program never came into existence, however, due to the resistance of the finance minister over particularities of the proposed budgetary spending on the programme. It was argued that the FTsP assumed the creation of a specific managing institution — named the Directorate - and supplementary technical groups comprised of public officials and experts in all units of federal government. ${ }^{24}$ Instead, it was decided to prepare a conception of the administrative reform. In preparing the conception the technocratic approach would again prevail. The conception would preserve the ideology of the reform and provide organizational and procedural flexibility for the reformers at the same time, as it would outline the goals of the reform, its major building blocks, as well as provide clear deadlines and assign agencies responsible for conducting various aspects of the reform.

The decision to replace the initial plan of preparing the federal targeted program with the 2005 Conception was criticized by some experts. For example, Professor Viktor Vishniakov criticized it, arguing that "saving a little [the reformers] deliberately ruined a very complex, methodic and operational work aimed at the establishment of a system of preparation and introduction of the first outcomes of the administrative reform." ${ }^{25}$ It was quite obvious that the political will to implement the reform, as it was initially planned, was compromised by the inability of reformers to allocate additional expenditures on the reform. Quite obviously, the existence of a specific department or directorate, solely

\footnotetext{
${ }^{23}$ In 2000 s there were prepared and issued more than sixty federal targeted programs aimed.

${ }^{24}$ See: A.Logunov (ed.) (2006). “Administrativnaia reforma v Rossiiskoi Federatsii: osnovnye etapy realizatsii." Analiticheskii vestnik Soveta Federatsii. Ser.: Problemy gosudarstvennogo stroitelstva. No.22 (310).

${ }^{25}$ Viktor Vishniakov (2011). "Administrativnaia reforma: 15 let poiskov kontseptsii." Zakonodatel'stvo i ekonomika, No. 7.
} 
responsible for conducting the most vital second stage of the reform, would be an important organizational contribution to the reform process. This decision would impersonate the reform process by allotting and specifying public officials, who would become responsible for conducting of the entire reform. Instead, interdepartmental governmental commission, where decisions were being made collegially, blurred responsibility among several agencies and officials.

Regardless of the downgraded status of the normative-legal documents of the reform (from presidential Decrees to governments' resolutions), the 2005 Conception was nevertheless a significant step forward in comparison with the documentation related to the first stage (i.e., 2003 presidential Decree No.824 that arranged measures of the first stage of the reform). The Conception outlined clear objectives of the reform, proposed a detailed step-by-step plan and described institutions' responsibility for conducting the reform. It must be specifically pointed out that for the second stage, reformers introduced clear, concise, and easily quantifiable parameters of governance that must be improved in the course of the reform. Perhaps for the first time in official documents, internationally recognized standardized indexes, such as the Governance Research Indicator Countries Snapshot (GRICS), Index of Corruption (issued by the Transparency International), as well as specialized polls measuring public perceptions on governance, were used as reference points of successfulness of the reform. Quite significant is the fact that all these indicators are not only external (i.e., they were not developed by the government itself), but also some of them were prepared by independent foreign organizations. By relying on these measures the reformers, on the one hand, reduced risks of influencing measurements of success; on the other hand, they decided to put the goals and objectives 
of the reform in line with the major trend of improvement of efficiency of public administration by following the common standards for estimation of governance efficiency. In other words, they deliberately or inadvertently put the Russian public administration in a comparative perspective.

It was outlined in the document that Russia's current position as described by these ratings could not be considered satisfactory; and immediate, but deliberate and balanced measures were needed in order to improve the situation. It was stated in the document that according to such indicators as perception of corruption, or transparency of authorities, Russia had been placed quite low in comparison with the most developed countries. The 2005 Conception concluded that "the sphere of state administration became the degenerating factor in the socio-economic development of the country and improvement of its competitiveness on the international arena." 26

Whereas the first stage of the reform put forward economic agents and the business community as the primary "customer" of the reform, the second phase took a more broad and holistic approach. Nine different goals of the reform were outlined in the 2005 Conception. Among them, only one clause, regarding limiting the state's penetration into the activities of economic agents was directly related to the interests of the national business community. Other goals were related to the overall improvement of the system of governance and performance of public officials. In terms of enhancement of efficiency of the public administration, both internal and external, the second stage of the reform was the most crucial one. The first stage was mainly dedicated to introduction

\footnotetext{
${ }^{26}$ Resolution of the Government of the Russian Federation No. 1789-r, from October 25, 2005. "Kontseptsiia administrativnoi reformy v Rossiiskoi Federatsii v 2006 - 2008 godakh."
} 
of a new system of public administration and the preparation of the bureaucratic corpus for radical changes; the second stage was expected to accomplish the goal of the functional fulfilment of the newly established structure. In order to achieve the proposed goals of the reform, the 2005 Conception stressed its five major 'vectors'. They were: performance-based management, standardization and optimization of activities of public institutions, resistance to corruption, improvement of efficiency of cooperation between the state and civil society, and finally, modernization of the system of monitoring the efficiency of the public administration.

Initially, the second stage was expected to be accomplished in three years: between 2006 and 2008. However, in 2008, upon request from the Ministry of Economic Development and Trade, the period for accomplishment of the reform actions was extended until 2010. The official reason for the extension was the need to introduce new aspects of the reform in order to improve its practical effects for the population. ${ }^{27}$ At the same time, reformers did not deny that the reform also suffered from delays and complications that also determined the need for an extension. ${ }^{28}$ The extension was legalized by governmental resolution No.157-r on February 9, 2008, effectively creating the second edition of the same conception that not only extended the temporal framework of the second stage, but also added some new reform measures.

It is interesting to compare both editions of the 2005 Conception. The newer version of the Conception did not exclude any substantial aspect of the reform which was introduced in the earlier edition. Instead, it introduced new measures that should improve

\footnotetext{
${ }^{27}$ See: Yuliia Vasil'eva (2008). "Reforme dobavili srok." Rossiiskaia Biznes-gazeta. No.642, February 26

${ }^{28}$ Ibid.
} 
the external effects of the reform, or in other words, improve the quality and efficiency of the provision of public goods and services. Furthermore, two more directions of the reform were added. The first one was related to the development of multi-functional public centres that should operate in accordance with the principle of 'single-window' service delivery. The second one was referring to a further improvement of the idea of electronic government (hereafter e-government) by a development of internet-based technologies for the provision of public services to the population. Overall, the chronology of development of the conceptual documents of the reform reveals an obvious shift of focus from limiting state penetration into the economy and excessive regulation of economic life to the improvement of the quality of public services.

All measures proposed in the second edition of 2005 Conception can be grouped into five distinct clusters. The first cluster refers to the optimization of the internal work of Russian officialdom. It includes measures aimed at improving the efficiency of the circulation of documents, coordination of activities of different types of public agencies and clarification of duties assigned to each governmental position. Among the major priorities of the public administration reform was the introduction of performance-based principles of governance. The performance-based governance approach is one of the few tools that were adopted from the New Public Management doctrine. The set of measures presented in the Conception was an example of a deliberate rethinking of the 'let managers manage' agenda in order to adjust it to the established three-layer system of public administration in Russia. Unlike in many other countries performing NPM-based reforms of their public administration, Russian reformers decided not to introduce a set of rigid performance criteria. Instead, they emphasized the importance of the practice of 
preparing specialized ministerial reports. These reports should include description of performance of an agency that submits it. Moreover, they were subject to revision and approval. Although this tool does not contain anything fallacious in itself, its efficiency is dependent on the political will of the superior agency to assure its proper use. The introduction of performance management should fundamentally transform principles and ideology of work of public officials. $^{29}$

Another set of measures, which were also referred to as an improvement of the internal organization of public administration in Russia, was related to the improvement of the regulatory functions of the state. It was stated in the 2005 Conception that one of the weaknesses of public administration was the absence of standards of quality and accessibility of state services. In order to change this, a set of specific measures was introduced. First of all, by 2008, federal and regional public administrations should introduce a full-fledged nomenclature of standards for public services. Secondly, also by the end of 2008, all departments of the executive branch of power should develop and approve their administrative regulations (administrativnye reglamenty) - documents that regulate internal rules of activity of public agencies and public officials. Thirdly, the 2005 Conception emphasized and prepared a 'road map' for the introduction and further expansion of the mechanisms of pre-trial appeal of decisions made by public institutions. This innovation was quite important in the Russian case as, at least in principle, it should improve responsibility of public agencies to consumers of public goods and services.

In addition to regulation of the internal service of public administration, the 2005 Conception emphasized the importance of improvement of instruments of quality control

\footnotetext{
${ }^{29}$ Performance-based management and budgeting will be discussed in detail in Chapter
} VI. 
of work done by public officials. In addition to the external audit, which is mainly focused on the post-factum establishment of erroneous or even malicious governance practices, the internal control and audit must be targeted at preventing ineffective decisions and violations of budgetary rules, or immediate correction of these malpractices. ${ }^{30}$ A large number of measures had to be accomplished between 2006 and 2008. These included changes in the organisation of administrative processes within the institutions of government, implying the introduction of clear and concise standards for the quality of services they provide and state functions they fulfil. These measures should create the basis for further improvement of the provision of services to the public, economic agents, and non-profit organizations.

The third cluster of reform actions, as proposed in the 2005 Conception, was based on the technological innovations. Recent developments in the sphere of informational technologies significantly influenced the nature of public administration and allowed the introduction of new principles of public service. The Conception addressed these issues by developing procedures and technologies for an internet-based provision of services and information regarding the activities of institutions of public administration. As stated in the Conception, the introduction of these measures would not only increase transparency of the government, but would also substantially improve accessibility of public services to the population.

Another aspect of improvement of accessibility and quality of service would be the introduction of the so-called multi-functional centres (MFCs). These centres should

\footnotetext{
30 "Organy ispolnitel'noi vlasti: funktsii, tipy, ekonomicheskii mekhanizm." (2002) Report of the Higher School of Economics., pp. 1-33 (Online), [URL: http://www.hse.ru/data/644/325/1234/report2.pdf] (Accessed May, 11, 2013).
} 
provide a wide spectrum of public services in one place. According to reformers, these centres would simplify the logistics and, therefore, accessibility of public services. Installation of MFCs implies an adoption of a NPM principle of a single-window service delivery. It was planned that these measures would be accomplished in 2008-2010. ${ }^{31}$

In addition, a set of measures to overcome corruption was prescribed in the document under the third cluster. A special emphasis was given to the development of a methodology of expertise of normative-legal documents, specifically on whether they are conducive to an implicit interpretation and therefore favour corruption. The reform project could not ignore one of the most detrimental problems of any public administration, namely corruption. Therefore, a large complex of quite multifarious measures, aimed at the functional optimization of executive bodies and specific actions against corruption was also included in the 2005 Conception. These measures were expected to be accomplished between 2006 and 2008. The process of optimization was no longer limited to the identification and liquidation of redundant functions, as it was during the first phase of the reform. The Conception proposed measures of standardization and legalization of procedures of introductions of new functions. An emphasis on a full-scale expertise of new functions was made in the document.

Outsourcing, yet another managerial measure, was introduced in the document in the context of optimizing activities of public institutions. As it was stated, prior to the full-fledged introduction, outsourcing procedures should undergo through a series of pilot projects in 2006-2008. The issue of reduction of public expenses was not limited to

\footnotetext{
${ }^{31}$ These were major introductions to the Conception after its extension in 2008. They embodied a substantial shift in orientation of the reform from improvement of interaction of the state with economic agents to improvement of service provision to the general population.
} 
outsourcing. The 2005 Conception also included a set of measures aimed at improving the process of state procurement. The reform in this sphere included modernization of the relevant legislature. A new rule required that all purchases for the needs of public institutions be done on a competitive basis, and that the winner of the contract should provide the best offer. Improvement of the procurement system included the development of the proper infrastructure on the basis of informational technologies and in accordance with the federal targeted program 'Electronic Russia'. According to the new principles, all orders from public institutions, whether federal or regional, must be placed on the particular internet portal www.gosuslugi.ru. Such innovations were expected to improve transparency and reduce costs of supplies necessary for activity of the government.

The fourth cluster of the reform was dedicated to improving cooperation between the public service and civil society. However, unlike many other clusters, this one was defined quite vaguely. The 2005 Conception posited that "it is essential to create efficacious channels of influence of civil society on the process of preparation and adoption... of decisions of executive power." ${ }^{32}$ Yet, in procedural terms, this idea was not operationalized in a set of definitive measures.

The reformers stated that improvement of the quality of public administration is deeply intertwined with the modernization of the system of information support. The idea of a more ubiquitous use of internet-based technologies in governance links various dimensions of the reform: from provision of services to the improvement of interactions between the state and civil society. This idea is important for improving efficiency of

\footnotetext{
${ }^{32}$ Resolution of the Government of the Russian Federation No.1789-r, from October 25, 2008. "Kontseptsiia administrativnoi reformy v Rossiiskoi Federatsii v 2006 - 2010 godakh."
} 
intra-government processes as well; and the planned reform measures in this field also constituted the core of the fifth cluster of the second phase of the reform. In this regard, efforts were focused on improvement of efficiency in working and analyzing the statistical data and introducing an effective system of monitoring the performance of public institutions.

Although the two-year extension of the second stage provoked some concerns regarding delays in the implementation of the reform measures due to bureaucratic resistance or other factors, the second edition of Resolution No. 1789 did not indicate reasons for the delays. In terms of time management, all measures that were prescribed in the first version should be accomplished in the initially planned time periods. According to the document, the extension was granted for the introduction of the newly added reform measures. Therefore, the documents themselves do not acknowledge difficulties and complications in the process of reform implementation.

The second phase of the reform presented a very broad and versatile agenda. The 2005 conception specified five distinctive clusters of the reform. Nevertheless, there can be established a generalized hierarchy of measures proposed for this stage, according to which two particular aspects dominated the second stage. The first one was related to further promotion of the New Public Management doctrine by means of deep transformation of the modus operandi of public officials. In this regard two features of the reform should be mentioned. On the one hand, there was an emphasis on the role of the state in the provision of services. On the other hand, there was an attempt to improve efficiency of service provision by means of the establishment of performance-based management and competition among the public agencies for budgetary funds. 
The second aspect was solely related to improvement of the organizational efficiency of institutions of the state. The idea of optimization of intra-governmental processes was described in terms of a further enhancement of the rules and procedures of daily activities of public institutions. Therefore, this aspect cannot be included into the NPM doctrine. In contrast, it may be stated that at the conceptual level it contradicts with the philosophy of New Public Management as it puts constraints on the 'let the managers manage' ideologemme. Yet it perfectly matches the ideology of building the power vertical, as discussed in the first chapter.

Essentials of NPM doctrine in the context of the reform of public administration in Russia will be given special consideration in the following chapter. However, in order to accomplish the analysis of the process of reform during the second phase, the aspect of procedural optimization will be discussed here. In the Russian case the idea of optimization was operationalized in the form of the introduction of administrative regulations (administrativnye reglamenty)—specific normative documents that establish the boundaries of authority and prescribe the mode of behaviour of public officials in particular institution of the government.

It was expected that administrative regulations should improve several aspects of governance. Firstly, they should systematize, bring order and, thus, enhance efficiency and functionality of public organizations by prescribing rules for the fulfilment of functions and imposing standards of public service provision. Secondly, regulation of activities of public officials should also produce additional barriers to corruption.

In order to successfully install administrative regulations, a series of normative documents was prepared and adopted. The general description of administrative 
regulations was made in governmental resolution No.679 of November 11, 2005, ${ }^{33}$ which provided key definitions and descriptions for the preparation and adoption of regulations by institutions of executive power. Administrative regulations for fulfilment of state functions and administrative regulations for provision of public services "define deadlines and sequence of actions (administrative procedures) of the federal body of executive power, principles of coordination between its internal divisions and employed officials, as well as its interactions with other federal bodies and organizations in the process of fulfilment of state functions or provision of public services. ${ }^{\text {"34 }}$ Each document must contain two sections: "General clauses" and "Administrative procedures". In the former section a particular state function of a public service is defined. In addition, all relevant laws and other normative-legal documents, as well as the name of the federal institution responsible for its implementation are mentioned. The latter section includes a description of the sequence of actions and deadlines in the process of fulfilment of a state function or provision of public service; rights and responsibilities of public officials involved in the process; and mechanisms of appeal and control over activities of public officials.

The ideology of the reform emphasized the need for a unification of principles and procedures of activity of public agencies. To match this objective, two framework documents (ramochnye documenty) in the form of governmental resolutions were prepared. They defined the modus operandi of all public institutions. The first document,

\footnotetext{
${ }^{33}$ See: Resolution of the Government of the Russian Federation No. 679 from November 11, 2005 "O poriadke razrabotki i utverzhdeniia administrativnykh reglamentov ispolneniia gosudarstvennykh funktsii i administrativnykh reglamentov predostavleniia gosudarstvennykh uslug."

${ }^{34}$ Ibid.
} 
titled "On the typical regulation of the internal organization of the federal executive bodies", refers to the organization of the work process within a particular federal executive institution. An administrative regulation of any federal executive body must include the following sections: 1) Regulation (reglament) of a federal organ of executive power, 2) administrative regulation(s) of fulfilment of state functions, 3) administrative regulation(s) of the provision of state services and office regulations (dolzhnostnye reglamenty) of public officials employed by the particular institution of the federal government.

The second document, titled "On the typical regulation of cooperation of the federal executive bodies", prescribes "general rules for the organization of work of the federal organs of executive power, concerning the fulfilment of their duties and the cooperation of these organs, including rules of interaction of federal ministries with federal services and agencies". ${ }^{35}$ Among other features, the document emphasizes the independence of each governmental body in fulfilment of its functions within the boundaries of its competence. Although this statement itself is rational and quite progressive, it was not supported by other clauses in the document. Thus, in clause 2.2 , it is stated that "the federal ministry passes normative and legal documents within the sphere of its authority, as well as in the sphere of authority of subordinated services and agencies." ${ }^{36}$ Thus, even on the basis of these documents, vertical subordination was promoted together with, or even more distinctly than, the horizontal separation of the layers of public administration.

${ }^{35}$ Resolution of the Government of the Russian Federation from January 19, 2005 No. 30. "O Tipovom reglamente vzaimodeistviia federal'nykh organov ispolnitel'noi vlasti". $\S 1.1$

${ }^{36}$ Ibid. $\$ 2.2$ 
The holistic approach towards the reform during the second phase reinstated itself in regards to the reorganization of the internal service as well. The document also imposed limitations on the penetration of public officials into activities of economic agents, stating that controlling and supervising institutions were deprived of authority to suspend activities of enterprises for any reason other than those which were established by federal laws. ${ }^{37}$

Although the second phase of the reform included many dimensions and proposed changes in various aspects of governance, as noted above, it was dominated by two major trends: optimization of internal administrative processes and the improvement of quality of service provision. Whereas at the conceptual level the second phase can be regarded as a continuation of the earlier stage, in reality, the reform signified a shift in focus towards a more traditional, nomenclatural approach to the optimization of processes within the public administration. The growth of attention towards the provision of public services at the expense of attenuation of attention towards economic deregulation is another remarkable feature of the second phase. Although this shift is quite remarkable, little explanation in official or academic papers is given about the factors that contributed to its emergence. It is difficult to surmise whether the growth of interest in internal regulations and provision of public services was determined by the decrease of topicality of deregulatory initiatives; or, in reverse, public (or even administrative) demand to improve public services forced the shift in focus. At the same time the overall political and economic situation in the country prior to the world financial crisis of 2008-2010 provided fertile soil for such transition. On the one hand, due to economic growth and

${ }^{37}$ Ibid. $\$ 2.11$ 
prosperity of the state, the urgency of introducing complicated changes into the economic sphere withered. On the other hand, after successful federative reform and installation of the power vertical the ruling political elite was more concerned with bringing order, improving compliance, and assuring efficiency of the state apparatus as the major conductor and implementer of policies. Also, on the eve of the upcoming electoral period and anticipated exchange of positions between Vladimir Putin and Dmitry Medvedev, public initiatives in the sphere of services provision would generate more political capital than promotion of economic deregulation.

\section{Third phase of the reform: 2011-2013}

The second stage was very important in terms of the proposed agenda as it included actions aimed at a total restructuring of the system of governance in Russia. Their complete implementation was imperative to achieve the goals of the reform. However, experts outlined delays in the implementation of some measures as well as transformations of some initial postulates of the reform. Even during the preparatory stage some experts outlined that the reform might face with some sort of resistance. ${ }^{38}$ The bureaucratic corpus, being simultaneously the object and subject of the reform, was required to reorganize itself. Therefore, deviations from the initial plan were almost inevitable, especially taking into account the lack of interest in the reform from the side of civil society and the irregular attention to it from the ruling elite. This trend is easily traceable on the basis of analysis of content of major printed media. Media attention to the problems of public administration reform was gradually declining since its start.

\footnotetext{
${ }^{38}$ Sergei Naryshkin, Tatiana Khabrieva (eds.) (2006) Administrativnaia reforma $v$ Rossii, Moscow: Infra-M.
} 
However, in 2010-2011 the reform which had almost withered away in public discourse and had been put at the background of the political agenda, was given a new impulse. Perhaps the world economic crisis provided new impetus to the reform of governmental institutions, although there were no obvious references to it either in the documents, or in public statements made by officials. However, immediate consequences of the crisis revealed significant drawbacks in the system of governance in the country that were not affected by the reform. The crisis also revealed that even in those spheres where the reformatory agenda was officially accomplished, government performance could not be considered satisfactory. As a result of the global financial crisis, Russia demonstrated one of the most dramatic declines of its major economic indices, with the recovery following only after stabilization and growth in international commodities markets. Despite a significant economic decline, the political system in the country remained stable mostly due to monetary reserves that had been accumulated in the precrisis years. These reserves however, were dissipating rather rapidly and as it was stated elsewhere, should the world economic crisis have lasted longer, its consequences for the political system of Russia could have been dramatic. ${ }^{39}$

The economic crisis not only revealed the impotence of state administration to act flexibly and decisively in order provide necessary measures that would help stabilize the economic and social situation in the country; it also exposed critical dysfunctionalities in the vertically integrated system of governance. As was shown through several examples (most prominent of them was the Pikalyovo unrest), this system demanded so-called

39 Joan DeBardeleben and Mikhail Zherebtsov (2013). "Economic Crisis, the Power Vertical, and Prospects for Liberalization in Russia," in Joan DeBardeleben and Crina Viju (eds.) Economic Crisis in Europe: What it Means for The EU and Russia. New York: Palgrave McMillan., pp. 177-200. 
manual control (ruchnoe upravlenie), or direct involvement of the country's leaders in resolving these crisis situations. Not only did the crisis show that public administration at the lower levels of the hierarchy was not capable of providing efficient solutions to administrative problems, but also it was recognized that it continued to create an excessive burden on business. In 2010 Elvira Nabiullina, then minister for economic development, acknowledged that the real costs of public services were 40 percent higher than those prescribed in normative and legal acts. ${ }^{40}$ The corruption in the public service also remained significant. Quite often individuals, while applying for public services, were forced to accept 'assistance from intermediaries, whose only objective was to facilitate a walkthrough of the bureaucratic process. ${ }^{41}$

All these factors acted as the backgdrop for continuation of transformation of public administration in Russia. The normative-legal framework of the third phase of the reform remained similar to the previous one. In order to systematize all necessary reform measures, a "Conception of reduction of administrative barriers and improvement of the quality of public services" was prepared (hereafter 2011 Conception). This Conception established the time period for the third stage that had to be accomplished in three years from 2011 untill the end of 2013. Although the 2011 Conception provided a detailed overview of the achievements of the reform at the earlier stages, it nevertheless concluded that "the results of implementation of the Conception of the administrative

\footnotetext{
${ }^{40}$ Evgeniia Zubchenko (2010). "Sem' raz skhodi." Novye Izvestiia, December 6. (Online. URL: http://www.newizv.ru/economics/2010-12-06/137497-sem-raz-shodi.html).

${ }^{41}$ Ibid.
} 
reform indicate continuing topicality of the majority of vectors of development of the governance system defined in it." ${ }^{, 42}$

In the 2011 Conception it was explicitly stated that separation of the reform of governance on independent thematic blocks (e.g. the reforms of public administration and civil service, budgetary reform, etc.) is no longer acceptable. The document explained that during earlier stages such a separation was meaningful due to the diversity of the reform agendas for each particular block of governance. However, once radical transformations were performed, all these reforms must become integral parts of the holistic reform of the system of governance in the Russian Federation. In addition they must reflect reform attempts in other spheres of public life. The conception for the third stage pointed out that the reform of public administration lies in the core of reforms of governance in Russia. This status of the reform had never been acknowledged explicitly during earlier stages. The reform of public administration was designed in such a way that its measures correspond with the objectives proposed in other, concomitant reforms.

During its third stage the reform of public administration pursued three major goals that, however, had not changed substantially from the goals of the previous phases. These goals are: improvement of the quality of public services provided by the federal, regional and municipal organs of public administration; reduction of the state's penetration into the economy, including excessive regulation; and an improvement of the work efficiency of public institutions. In order to achieve these goals reforms should be performed in several different aspects of governance and include managerial, traditional

\footnotetext{
${ }^{42}$ Resolution of the Government of the Russian Federation No. 1021-r of June 10, 2011. "Kontseptsiia snizheniia administrativnykh bar'erov i povysheniia dostupnosti gosudarstvennykh i munitsipal'nykh uslug na 2011 - 2013 gody."
} 
regulatory and technological dimensions. These aspects are: the introduction of performance-based management and planning, further standardization and regulation of public officials' activities, development of internet-based technologies of governance, introduction of multi-functional centres for the provision of public services, optimization of functions of public institutions and measures aimed at fighting corruption.

Although these aspects are rather distinctive, the proposed classification of the reform dimensions is conditional, as reforms that appear under one category, usually deeply intertwined with the reforms, were assigned under other categories. This does not only relate to the issues of introducing new, internet-based administrative technologies that influence the internal aspects of the modus operandi of public officials, the ways general population can receive public services, and business can deal with the state. It relates to other aspects as well. For example, the introduction of multi-functional centres for the provision of services not only eases the process for citizens, but also demands a transformation of principles of work of public officials involved into the process.

The 2011 Conception demonstrated that the shift of the major focus of the reform from deregulatory activities to an improvement of services provision for the population, which was marked during the second phase, remained constant. It appears that the ruling political elite was more interested in improving the situation in the sphere of public services, than in creating a larger and more independent economic system. It seems obvious that under given political and economic circumstances the latter objective was much harder to achieve than the former. The very architecture of the political system gave more options to the reformers to invigilate improvement of the internal performance 
of public administration and ensure that officials followed the prescribed modus operandi in order to reduce the state's involvement in the economic sphere.

Modernization of the approach and an improvement of the quality of public services became the mainstream issue of government reforms in the country in the middle of the second phase. It retained its topicality throughout the third stage as well. Most reform measures during the third stage were organized to achieve an improvement in the sphere of public service. The objective of this sector of the reform was to improve the customer-oriented ideology among public officials and to reduce time-limits and costs of public services for the population. Major steps in this direction were introduced during the second phase, when the initial 2005 Conception was extended for two more years and such an innovation as multi-functional centres of provision of public services that are based on the "single-window" principle, was introduced. During the third phase the development of multi-functional centres was to be continued and expanded in addition to further normative regulation in this sphere, including the regional level.

Development of these centres involves substantial change in the organization of administrative processes, not only between different institutions, but also between different departments and even employees within an organization. The "single-window" approach itself significantly influences the principles of bureaucratic behaviour, demanding the qualitative improvement of cooperation between officials, departments, and even institutions, in order to accomplish the goal of the provision of a particular service. Under this approach it is not the applicant's concern to follow his application through the steps of administrative process. With development of the 'single-window' service delivery principle, these duties are put on the shoulders of public officials. 
Therefore, administrative regulations that were discussed earlier in this chapter must be adjusted in order to accommodate the procedural requirements needed for proper implementation of the new approach. Besides normative regulations, it was planned to create a united informational system for support of the activities in these centres.

The 2011 Conception also described in full the set of measures needed to maximise the use of the internet and information technologies in the provision of public services. A wide variety of measures were discussed in the document: from an enhancement of quality standards of service provision and comfort of applicants (such as equipment of waiting rooms with indicator boards and personal computers) to an integration of the informational systems installed in these centres with other automated informational systems of all institutions of government.

Expansion of information technologies in the sphere of public services was not limited to the issues of development of the multi-functional centres. In congruence with the federal programs "Electronic Russia (2002-2010)" and "Information-oriented society (2011-2020)" the 2011 Conception stated that public services should be provided in electronic format if such an opportunity is available. It also included a set of steps necessary for instalment of this innovation. At the core of the design was the specialized internet portal 'gosuslugi.ru'. It should present citizens and other applicants with the nomenclature of services that would be available in electronic form, as well as a detailed description of application procedures and deadlines. The portal should include services that are provided not only by federal, but also by regional and municipal institutions. In order to enhance the provision of services in electronic form, the 2011 Conception ordered a complete inventory of the list of public services aimed at establishment of an 
exhaustive nomenclature of services that demand physical presence of the applicant during the application procedure. At the same time, the reorientation towards greater use of distant and on-line methods for the provision of public services did not substitute completely for its traditional forms.

Measures aimed at computerisation of this sphere included a set of measures that should transform the internal work of public administration. Among the top priorities here is the idea of periodical monitoring of quality and accessibility of services on the basis of a unified methodology of intradepartmental surveys.

Another objective put forth during the third phase of the reform referred to improvement of functional efficiency of public administration. Needless to say the significance of this vector has remained constant since the launch of the reform in 2004. Yet, the reform agenda has changed since the second phase. The work on the development and introduction into the service of administrative regulations had been largely accomplished prior to the beginning of the third phase. Therefore the 2011 Conception only stated the need to continue work in this area without further explanations of the process. Quite remarkable is the fact that the issue of improvement of functional efficiency was not linked to managerial reforms. Instead, the 2011 Conception focused efforts on the further promotion of the idea of 'electronic government', not only in relations between the government on the one hand and the civil society and economic community on the other, but also within the government itself. Integrated automation of the processes of government involves the creation of a unified and vertically integrated electronic system of "Governance" ("GAS Upravlenie"). This system pursues several key objectives. First of all, its introduction allows the centralization of not only informational 
resources needed for the efficient work of various public institutions, but also the system of monitoring and control over this work. Second, the electronic system must facilitate a decision-making process on all levels of public administration by providing immediate access to all available information from different sources.

Overall, the 2011 Conception demonstrated two quite important tendencies in the improvement of internal functional efficiency of public administration. The reform affirmed the chosen trend for development of the model of information society in the country. Reformers apparently equate such terms as 'informatization' with 'improvement of efficiency'. The other trend is a certain domination of the vertically integrated and centralizing approaches to the modernization of public service and especially to the transformation of its internal managerial practices. Obviously this also occurs at the expense of inherently decentralizing New Public Management practices.

Although the block of measures related to relationships between the government and the business community was not the highest priority of the reform, it nevertheless was given a comprehensive description. Perhaps the issues of cross-sectorality of the reform of public administration were related to this aspect of the reform more than to other ones. The issue of state-business relations was addressed in the 2011 Conception as being system-wide and thus demanding attention that stretches beyond purely administrative issues. The Conception established a wide variety of measures that would facilitate further deregulation of the economic process in the country. First of all, there was proposed a set of measures, aimed at a further development of the system of licensing business activities. It was stated that licensing is a rather radical instrument of control over the business community and therefore must be used only when it is 
necessary (when there exists an obvious risk for considerably big groups of people). If this condition is not applicable, then other forms of control and regulation should be invoked. In order to pursue the goal of a reduction of the practice of licensing business activities, the Conception proposed a two-step plan. The first step involves a unification and standardization of the process of licensing, accepting only limited list of cases that demand an exclusive approach. The second step involves the creation of a complete list of activities that demand licensing. This step includes simultaneous revision and unification of adjacent laws and other normative documents in order to avoid conflicts. Also, the process of licensing must involve electronic document circulation. It is expected that as a result of these measures, the quantity of the types of business activities that need licensing will be reduced from 272 to 255 , furthermore the procedure will be simplified and the deadlines and costs will be limited. ${ }^{43}$

Actions in the sphere of improvement of the state function of accreditation are focused on the establishment of a unified governmental institution - the Federal Service for Accreditation - and transmission of the function of accreditation from all other agencies to this organization in order to enhance efficiency of the process and reduce expenses.

Regardless of the modernization attempts, licensing and accreditation still remained the most conservative aspects of state-business relations. Therefore the major attention of the reform in this sphere was directed at limiting the ability of government to influence business activities. It was proposed that the old policy when governmental

\footnotetext{
${ }^{43}$ Resolution of the Government of the Russian Federation No. 1021-r of June 10, 2011. "Kontseptsiia snizheniia administrativnykh bar'erov i povysheniia dostupnosti gosudarstvennykh i munitsipal'nykh uslug na 2011 - 2013 gody."
} 
agencies issued permits and registration documents for new companies must be changed. Instead a new regulation was introduced that established that business enterprises are only obliged to notify the corresponding governmental agencies when they begin their activities. Obviously, this policy is the subject for discretion under peculiar circumstances; especially in the situations when the type of economic activity is potentially hazardous for considerable groups of people. Regardless of some limitations, this was a very important deregulatory initiative that should simplify the procedure of starting up a business enterprise and limit discretionary abilities of public officials, especially at the grass-root level. Public officials would not be able to delay, or reject applications; their basic function would be to keep and update the register and provide obligatory services (such as issuance of necessary certificates and other documents). The major beneficiaries of this innovation should become small and mid-size business enterprises. The growth of the quantity of these enterprises should testify to the efficiency of this innovation.

The deregulatory agenda of the reform was not limited to these initiatives. The 2011 Conception also proposed the introduction and development of the mechanisms of self-regulation in the sphere of the economy. As was stated in the document "mechanisms of self-regulation should be the means of curtailment of power authorities of governmental institutions and administrative barriers for the development of entrepreneurship" in Russia. ${ }^{44}$

The provided analysis of the process of reform reveals its several crucial features. First of all, it is the change of the focus of the reform. Initially the reform's major

${ }^{44}$ Ibid. 
objective was seen as predominantly imposing deregulation and limiting the state's involvement into business activities. However, there was a shift in orientation of the reform's major target group. Whereas at the earlier stages the reform measures were focused on the interests of the business community, in later stages provision of services to the public at large was made its top priority. Secondly, the eclectic and technocratic method of carrying the reform combined together two rather contradictory agendas: standardization and regulation of administrative processes and introduction of NPMbased administrative technologies.

\section{Analysis of performance}

The reform of public administration has been an ongoing project for the current political elite for more than a decade. Its current, third stage, is coming to an end. Therefore, it is quite justified to draw some conclusions regarding the achievements and failures that occurred in the process of its implementation over the last ten years. Speaking of the institutional (or structural) aspect it may be observed that, in principle, the reform, to a greater extent, stabilized the situation with public agencies at the federal level. Since the introduction of the three-layer system of public administration, the overall quantity of federal public institutions never increased by more than 10 percent. Only in the first quarter of 2008 did the overall quantity of federal executive offices increase by 11 units (from the initial 76 to 87 ). This situation lasted for only a quarter of a year and after that a trend of gradual decline in the quantity of institutions can be observed. The situation stabilized in the beginning of 2011 when the quantity equalled 79, or only 3 units more than was initially proposed in March 2004. 
In this regard, the overall situation may be described as stable. However, it is important to analyze whether the reform has brought stability of the institutions as well. This additional factor describes institutional stability—as there could be a situation when, without changes in the quantity of public agencies, there occurred substantial changes in their functions and responsibilities. The phenomenon is described in this dissertation as institutional volatility. Functions and responsibilities of a federal institution can be extended or reduced, changing significantly its administrative capacity. Alternatively, functions that were previously assigned to one institution can be split between several, sometimes newly introduced institutions of government. Both these situations describe rather different processes, and their effects on governance are likely to differ. In order to analyze institutional volatility of the Russian government a peculiar empirical method was utilized. This method involved establishment of correlation between the quantity of institutions at each level of the government and the amount of spheres (sectors) of economic or public life that are supervised by one or another institution.

Figure 1. Institutions of the federal government since the beginning of the reform (2004-2013)

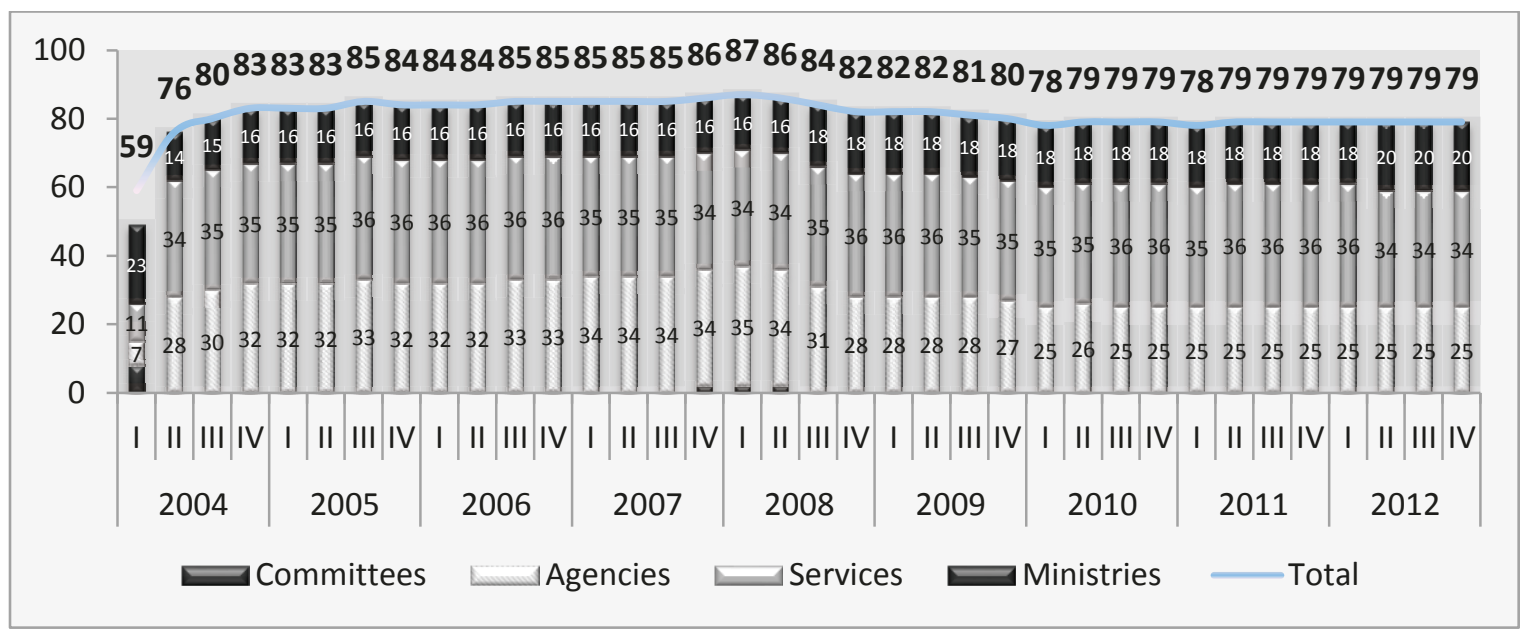




\section{Figure prepared by the author. ${ }^{45}$}

In case of ministries between 2004 and 2013 an increase of 42 percent in quantity of institutions can be observed. Decree No.314, which introduced the new system, initially proposed 14 ministries. In other words, the Decree defined several major sectors of public, social, and economic life of the country that demanded direct governmental oversight. Broadly speaking, approximately twenty sectors may be outlined (see Appendix III). They were united into 14 ministries that performed functions of policymaking, normative and legal regulation, as well as regulation of activity of various agents. After two and a half months, two more agencies were added and this system existed for four years and was changed in 2008 as a result of the presidential elections and changes in the political life of the country that followed after. The government that was formed by prime-minister Vladimir Putin in 2008 included 18 ministries. The next change in structural capacity of the government at the ministerial level coincided with another electoral cycle. The new prime-minister Dmitry Medvedev proposed the government that included 20 ministries.

Thus, as the reform proceeds, we observe a gradual increase in the quantity of federal ministries. However, scrupulous inspection of sectoral capacity, or inclusion of new spheres under political-executive oversight, reveals that there were fewer genuinely new spheres added as a result of these ministerial reshuffles. Thus in 2004, the Ministry for Regional Development was introduced, signifying the political importance of

${ }^{45}$ The quantity and structure of institutions of the federal government are assessed quarterly on the basis of multiple presidential decrees "On the structure of the federal organs of executive power" No.314 from March 9, 2004; No.649 from May 20, 2004; No.1274 from September 24, 2007; No.724 from May 12, 2008; and No.636 from May 21,2012 . In addition, changes to the structure of the federal government were introduced by specific presidential decrees. Data presented in the first quarter of 2004 shows the structure of federal government prior to the reform. 
establishing regulation and developing programs of sustainable regional development. The second ministry that was also introduced was only partially new. By creation of the Ministry of Informational Technologies and Communications, the government emphasized the importance of regulation in this rapidly growing sector of national economy. This creation signified the importance of the sector in the current economic circumstances, but this state function was not entirely new, as the initial establishment of policies in the sphere of communications were assigned to the Ministry of Transport and Communications. This particular case testified not to the actual expansion, but rather further specification and transferring of functions between institutions of government. Although in the years that followed the adoption of the new system, the ministerial level of the government expanded 42 percent in structural terms, in terms of coverage of the various spheres of public life and sectors of the economy, the growth was more moderate. In this regard only four more spheres were given ministerial oversight. All this leads to a conclusion that at the ministerial level, institutional growth must be explained not in terms of bureaucratic expansion, but rather in terms of search of better organizational forms. Among the four spheres included in the course of development, only two possess characteristics of general spheres, and the other two can be called specific. Ecology and regional development may be included in the former group, and sport and development of the Far Eastern region - in the latter.

In regards to the layer of federal services, the situation is rather different. Unlike in the case of ministries, the quantity of controlling institutions did not increase. The initial variant proposed 34 federal service and inspectorates, with the same quantity indicated in the 2012 government. During the last eight years, the maximum quantity of 
this type of governmental institutions never exceeded 36. Of the initially proposed 34 federal services, 26 did not undergo any institutional restructuring. Other services were subject to reorganization or liquidation. The second government after the reform had already indicated changes in six services (three were discontinued and three new ones were created). The next government, which was formed in September 2007, continued the trend. In this case, six services were also reorganized: two were liquidated, one was reorganized and three more were added. Overall, during the course of the reform, thirteen new services were created and thirteen were liquidated. It is interesting to point out that five of the newly created services did not survive reorganizations. Most of these services were active during the period of work of one particular government. If this observation is compared with developments in the ministerial corpus, where not one newly created ministry was liquidated afterwards, it is possible to conclude that the institutional volatility of the second layer of public administration is definitely higher than that of the first one.

With the establishment of the three-layer system, the institutional characteristics of federal agencies improved significantly. Right after the beginning of the reform, the quantity of federal agencies, as the only institutions de-jure responsible for the provision of public services, grew more than twofold. Twenty federal agencies were initially established. Later the number of agencies increased and achieved its peak of 35 organizations in the first quarter of 2008. After this, the amount began to gradually decline. Finally, since mid-2010 the quantity of federal agencies has stabilized at 25 . However, only 13 (out of 28) of initially introduced agencies remained active in the following years. As many as 26 new agencies were created in the course of reform. 
Figure 2. Volatility of institutions of the federal government since the adoption of the threelayer system of public administration in Russia

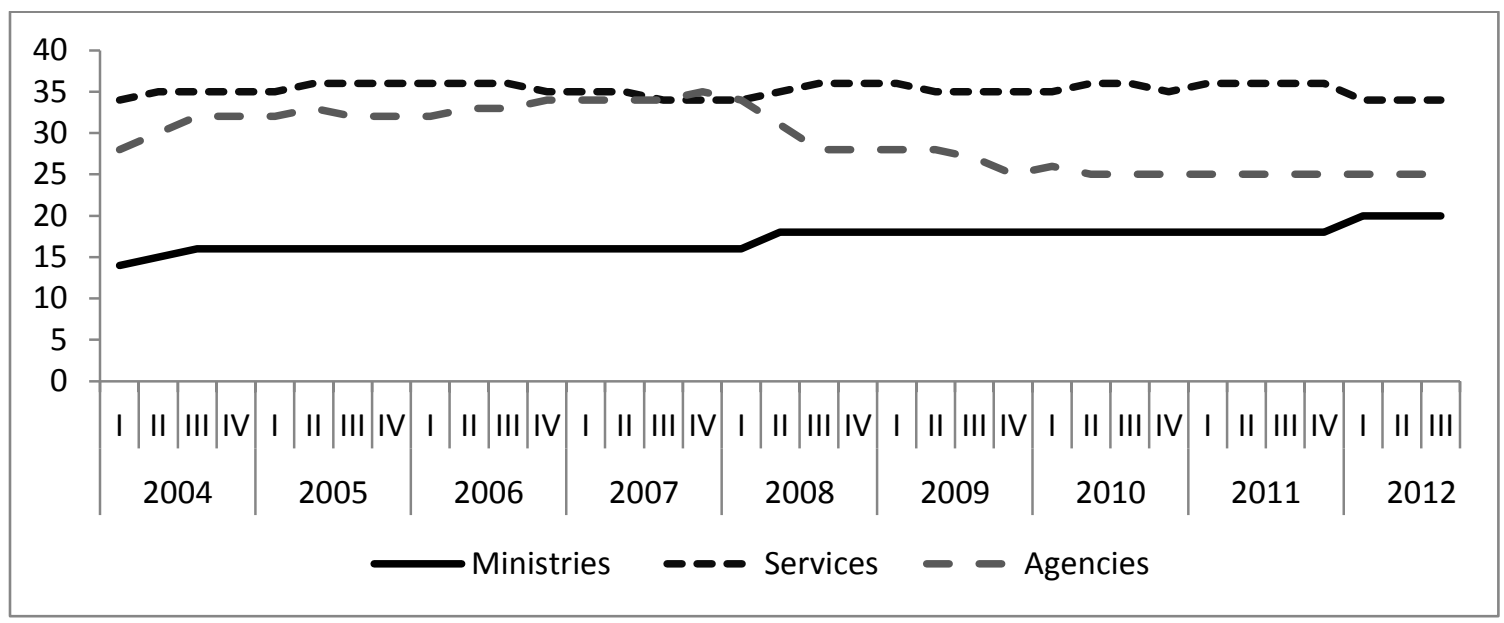

This data makes federal agencies the most volatile type of institutions in federal government. Most changes in its nomenclature (as compared to the previous or next period) occurred during the second presidential tenure of Vladimir Putin, when 13 new agencies were introduced and only 3 of them were liquidated as a result of the next cabinet reshuffle. If we compare volatility of institutions of government, the highest index will be assigned to federal agencies as only a half of the initially introduced agencies remained unchanged throughout the course of the reform. Federal services have been pretty much stable as changes affected only $1 / 5$ of the entire nomenclature of this type of governmental institutions. The case of ministries is the complicated one, as no ministry was liquidated in the course of the reform. Yet the functional capacity of the only eight initially introduced ministries remained stable. All others were reorganized in one way or another.

The introduction of the three-layer model of public administration also implied changes in the nature of remuneration of public officials at all three layers of the federal government. It was assumed that the quality of work of federal ministries and federal services, which were deprived of functions of property management and the provision of 
state services, could not be assessed on the same performance-based principles as the work of the federal agencies. Therefore the hypothesis that was tested in this regard states that in order to improve performance of such institutions of public administration, such as ministries and services, as well as to reduce negative effects, such as corruption, remuneration of public employees of these agencies has to be performed according to principles that differ from the principles of remuneration of public employees working for federal agencies.

The work efficiency of public agencies can be assessed on the basis of direct quantitative performance indicators. This gives a fertile basis for introduction of business-like performance oriented strategies of remuneration, such as bonuses, limiting at the same time the base salary. In principle, this would establish conditions for improvement of performance of public agencies. However, the same logic cannot be used for public officials working in ministries and services, as their activity is not directly quantifiable. In reverse, in their case, the emphasis has to be done on improvement of their base salary and other types of monetary rewards based on their qualifications, length of service etc.

This hypothesis is tested on the basis of data on the remuneration of public employees of Russian federal government institutions. The performed analysis compares average salaries of all three types of governmental agencies. A one-way ANOVA test is used to assess the significance of differences in salaries of public officials who are employed by the federal government. The data, provided by the Russian Service of State Statistics 'Rosstat', was used to test the hypothesis. The data is grouped annually, and reveals the average salary for each type of institution of the federal government. To 
compare and test the assumptions, two periods - 2010 and 2012 were used in this analysis, where the latter period is used as the primary source, and the former was considered the controlling source. Such an approach to sampling was justified by the following argument: the year of 2010 signified the end of the extended second stage of the reform that, according to the logic, should finish the process of functional reorganization of the structure of public administration introduced in 2004. By this time, the major principles of work of the new public administration had to be settled. The year of 2012 is significant in two other ways. First of all, the data from 2012 implicitly reveals performance of public administration in the middle of the third stage of the reform. Secondly, whereas 2010 can be marked by the end of the financial-economic crisis in Russia (and the world), the year of 2012 can be assumed relatively stable in social and economic terms. Continuity of trends in both time periods would follow the assumption that with respect to funding the public service, the reform achieved stability. Discrepancies in the results, on the other hand, would suggest that the desired objectives were not achieved.

The given data was grouped in three categories in accordance with the goal of this test, namely "Federal Ministries", "Federal Services" and "Federal Agencies". For each category an aggregate average salary was calculated.

The analysis reveals that in both cases ministerial employees received the largest salary of all three groups. The average for 2010 was $60,567.41$ roubles with minimum average salary of 43,245 roubles, shown in the Ministry of Education and Science and the maximum average salary of 81,362 roubles shown in the Ministry of Defense. The average monthly salary of federal services' employees in 2010 was 46,066.1 roubles and 
that was $14,501.31$ roubles lower than the average salary of ministerial employees. The lowest average salary of 30,248 roubles was revealed among the employees of the Federal Penitentiary Service and the highest average of 70,918 in the Federal Tax and Revenue Service. It seems significant to point that in 2010 the average salary of employees of federal agencies was higher than that of the employees of state services. With average of $48,462.44$ roubles it was 2396.34 roubles higher than the average salary of federal services employees. In addition, the salary of federal agencies' employees is the most disperse: the minimum is 35,740 roubles and the maximum is 134,964 . This resulted in the largest standard deviation of all three types of governmental institutions.

Figure 3. Federal public employees' remuneration by type of institution. ${ }^{46}$

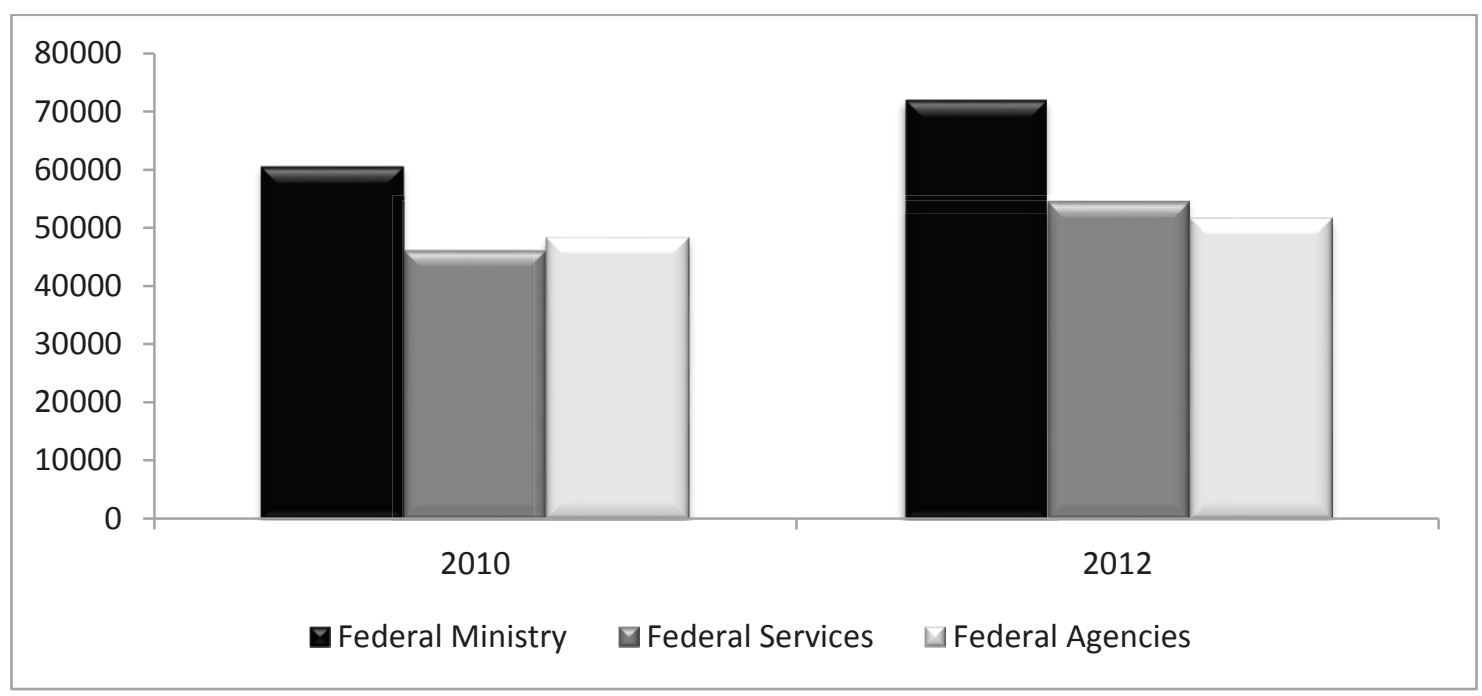

Figure 3 is prepared by author using official statistics from Rosstat (Russian Statistical Agency).

In 2012 the trend in salary diversification changed slightly. Public officials in federal ministries continued to receive much higher salaries than their colleagues in federal services and agencies. The average monthly salary on the ministerial level was $71,912.4$ roubles, with the minimum average of 51,363 roubles paid in the Ministry of

${ }^{46}$ Note that salaries are listed in Russian rubles per month. 
Transport and the maximum average of 102,063 roubles paid in the Ministry for Emergencies. However employees in federal services started to earn more than their colleagues in federal agencies. The average salary of the former group is $54,559.87$ roubles with the minimum salary paid to the employees of the Federal Couriers Service and the maximum of 103,847 roubles paid in the Federal Treasury. Employees of federal agencies were paid 2962 roubles less than their colleagues in federal services. Their average salary was 51,597.29 roubles per month. As in case of 2010, this layer also showed the largest standard deviation of all three, however this time the dispersion was not visually too different from that on the ministerial level. The spread of salaries among federal services employees was the smallest of all three in both measured periods.

Figure 3. visualizes the differences in salaries, and it is quite evident that the category of federal ministries' employees shows quite distinctive pattern in salary distribution. Yet, the differences between the other two groups are not that evident. In order to verify the observation, the analysis of variance method (ANOVA test) was used to compare the differences in remuneration between the three groups of federal government employees. The results of the test are presented in the table below. The test indicated significant difference between all three groups taken together in both samples (2010 and 2012). And the variance increased in the 2012 sample in comparison to the 2010 one. However, in both samples the variance in the salaries of employees of federal services and federal agencies was found insignificant. The year of 2012 is also interesting regarding an increased diversification of remuneration between the groups of federal ministries and federal agencies. In comparison with the 2010, the level of diversification improved threefold. 
Table 1. Analysis of significance of salary diversification among the three groups of federal government employees.

\begin{tabular}{|l|r|r|r|r|}
\hline \multirow{2}{*}{ Between all groups } & \multicolumn{2}{|c|}{2010} & \multicolumn{2}{|c|}{2012} \\
\cline { 2 - 5 } & \multicolumn{1}{|c|}{$\mathrm{F}$} & \multicolumn{1}{c|}{ Sig. } & \multicolumn{1}{c|}{ Sig. } \\
Between Ministries and Services & 5.242 & .008 & 8.42 & .001 \\
Between Ministries and Agencies & 21.603 & 0 & 13.401 & .001 \\
Between Services and Agencies & 4.173 & .048 & 13.057 & .001 \\
\hline
\end{tabular}

The given analysis leads to a conclusion that at least in case of the policy oriented institutions of the federal government, the reform was able to achieve the proposed goals of instalment of the NPM-based principles of remuneration. Moreover, in 2012 the scope of diversification improved in comparison with 2010. However, with respect to two other groups, the data was not consistent with the hypothesis. This situation prompts several conclusions. First of all, it is important to state that a lack of diversification of salaries between the groups of federal services and federal agencies hampers installation of NPM principles in the Russian case. Secondly, an ideal situation would infer a diversification of salaries between all three groups. Yet, as the hypothesis stated, even the distinctiveness of salaries between federal ministries and federal services, on the one hand, and federal agencies on the other, would serve as a confirmation of the effectiveness of the adapted NPM principles. However, the given results implicitly confirm the existence of another trend in public administration that was described earlier in this chapter. That is the prevalence of the vertical trend in the orientation of public agencies, particularly as we have the classic situation of agential hierarchy and subordination (even in terms of remuneration) of the lower levels of public institutions to the ministerial level. This argument may be further supported by introduction to the analysis of data concerning the remuneration of employees of the Presidential Administration. Their salaries in both 2010 
and 2012 samples were higher than the average salary of the ministerial employees (85881 roubles and 132309 roubles respectively). This data fully corresponds with the argument discussed in Chapter 2 of this dissertation about the importance of this division in the distribution of authority and political power within the executive branch.

The introduction of administrative regulations was among the most topical of issues of the administrative reform during all its phases. As it was planned, this aspect had to be largely accomplished by the end of the second phase. Therefore, the 2011 Conception concluded that 447 administrative regulations were approved at the federal level, and at the regional and municipal levels more than 6000 and 4000 regulations, respectively, were approved. ${ }^{47}$ The given numbers show that overall, the process of instalment of administrative regulations was conducted rather successfully. It was not obstructed by the institutions; nor were significant delays noticed. The public service showed a remarkable discipline in respect to the implementation of this aspect of administrative reform.

At the same time, analysis cannot be limited only to nominal indicators. It is rather important to analyze to what extent the introduced of regulations improved the quality of the public service. To find this, a series of specialized surveys were conducted by experts from the Higher School of Economics upon request from the Ministry of Economic Development. In some earlier researches, experts stated that "overall, the level of introduction of administrative regulations may be characterized as insufficiently

\footnotetext{
${ }^{47}$ Resolution of the Government of the Russian Federation No.1021 of June 10, 2011 "Kontseptsiia snizheniia administrativnykh bar'erov i povysheniia dostupnosti gosudarstvennykh i munitsipal'nykh uslug na 2011 - 2013 gody."
} 
high. ${ }^{" 48}$ An in-depth analysis of administrative regulations also revealed several crucial issues. First of all, not all institutes show equal diligence in adopting administrative regulations. The review revealed the "leaders" (like Federal Migration Service) and "boycotters" (like Federal Treasury, or Ministry for Culture). Experts also outlined that the introduced regulations could not help to overcome the deficiencies in the system of service provision, especially with respect to the waiting times and standards of services provided. Consulting services as well as provision of information regarding the services and necessary procedures for receiving them were also estimated to be insufficient. In some instances, administrative regulations did not contain sufficient and appropriate procedures, although the quantity of such cases was not too large. Regardless of the noticed inconsistencies, experts concluded that "regulation had become a persistent practice of the Russian governance." ${ }^{, 49}$ Notwithstanding some substantial drawbacks, public opinion polls reveal that introduction of administrative regulations was evaluated as a positive innovation by officials as well as stakeholders. At the same time, recommendations prepared by experts on the basis of the conducted survey signify that this aspect of the reform also needs substantial improvement.

If all measures were fulfilled as expected, Russian public administration should have been transformed substantially. However, many critics of the reform argue that, so far, the reform has not been fully successful. Many statements in support of these arguments are theoretical in substance. Some others focus on juridical discrepancies. Yet, as far as the reform proposed clear and objective criteria for evaluation, it would be

\footnotetext{
${ }^{48}$ A. Zhulin, O. Ivanova (2008) "Monitoring vnedreniia administrativnykh reglamentov." Problems of State and Municipal Government No.2., p.180

${ }^{49}$ Vserossiiskii monitoring administrativnykh reglamentov - 2009. Moscow: Higher School of Economics.. p.10
} 
important to address them in this chapter. The criteria were stated in both conceptionsprepared for the second and third phases. Among the major indicators reformers referred to are the Governance Performance Indicators (GRICS), developed by the World Bank. Both the 2005 and 2011 Conceptions outlined two parameters, according to which the improvement in governance in Russia should be measured: 1) efficiency of public administration (governance) and 2) the quality of state regulations.

It was stated in the second edition of 2005 Conception that Russia's scores on both indicators at the beginning of the reform did not even match the scores achieved by the majority of developed countries. According to the efficiency index, in 2004 Russia scored 48.1 (out of 100) and 30.5 (out of 100) on the quality index. It was expected that by 2010 , as a result of the reform, the country's position would substantially improve. The value of both indices for Russia should not be less than 70 . These plans were corrected, however, in the third (2011) Conception of the reform for the period 20112013. It was stated in the document that with respect of the "efficiency" index, Russia even lost its position in comparison to pre-reform measurements. In case of the quality of state regulation, there was some minor improvement; however it was significantly lower than the planned improvements. Such weak performance of Russia stimulated downgrading expectations for 2014. As it was stated in the document, by 2014, Russia must achieve the score of 65 on the efficiency of governance index and 60 - on the index of quality of state regulations.

Figure 4 shows the desired and actual scores for both indicators that were mentioned in both Conceptions. It is evident that Russia did not improve the performance of the public administration. Moreover with respect to the governance efficiency index, 
Russia's score fell slightly even in relation to the previous measurement. In 2004, when the new structure of public administration was introduced and the active phase of the reform began, Russia's score was 43.9.

Figure 4. GRICS performance indicators.

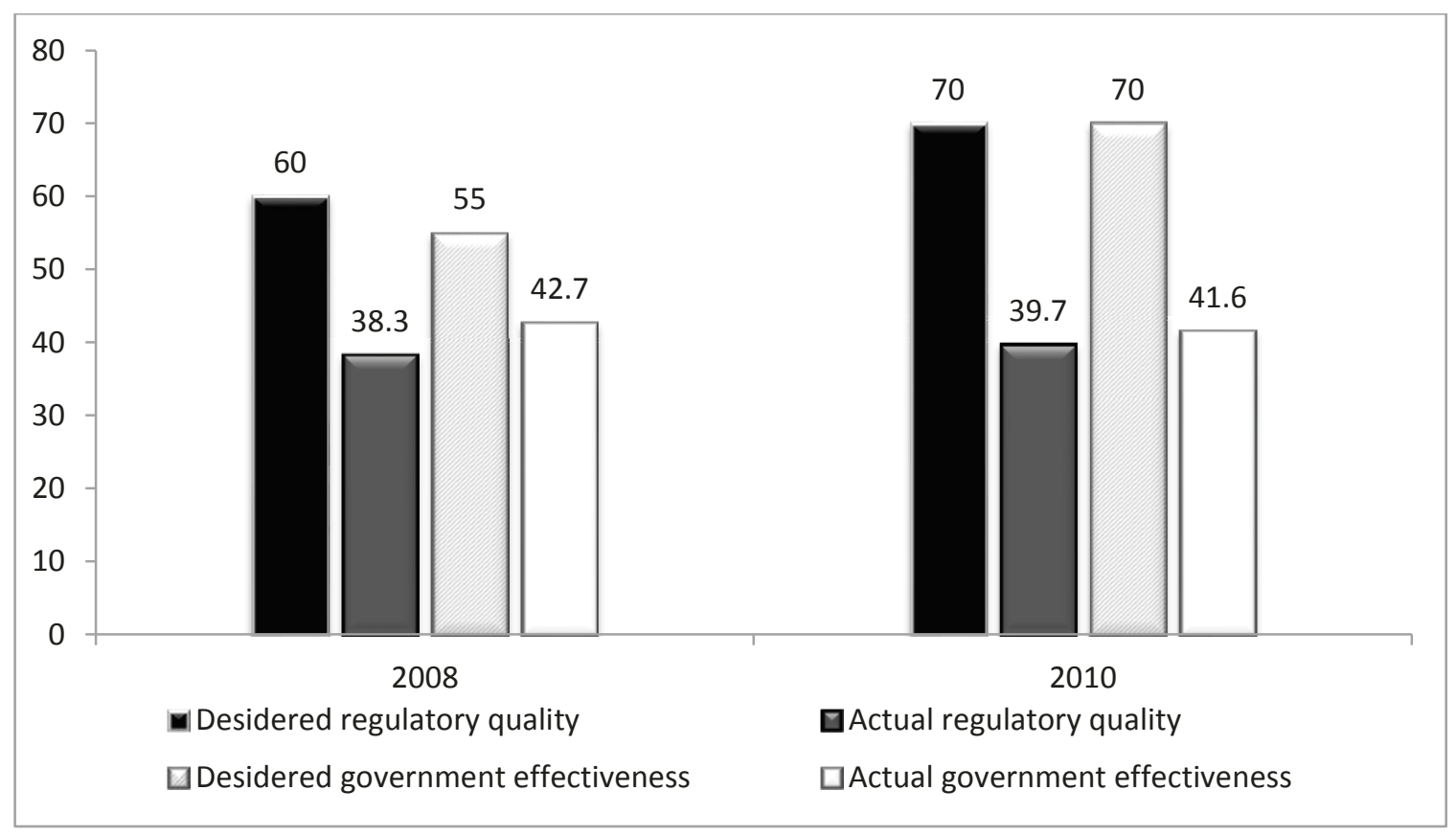

Figure 4 is prepared by the author using data from Governance Research Indicator Country Snapshot. ${ }^{50}$

A more detailed analysis of the performance of Russia according the given indices provides more evidence on whether the reform of public administration was a successful project. Figure 5. provides continuous data on Russia's performance over the decade-long reform. The governance performance index is issued annually by the World Bank. Its major advantage, namely the methodological stability of this index, allows it to assess Russia's government performance shortly before the beginning and during all three stages of the reform, as well as in comparative perspective. The presented graph shows the dynamics of Russia's government efficiency index in 2000-2011. The scores of

\footnotetext{
${ }^{50}$ The data, used in this Figure is available online on the web-site of the Project at: http://info.worldbank.org/governance/wgi/index.aspx\#home (Last accessed: December 7, 2013)
} 
Russia are portrayed vis-à-vis the average aggregated scores of the EU and OECD countries.

Figure 5. GRICS government efficiency index 2000-2011: Russia in comparative perspective.

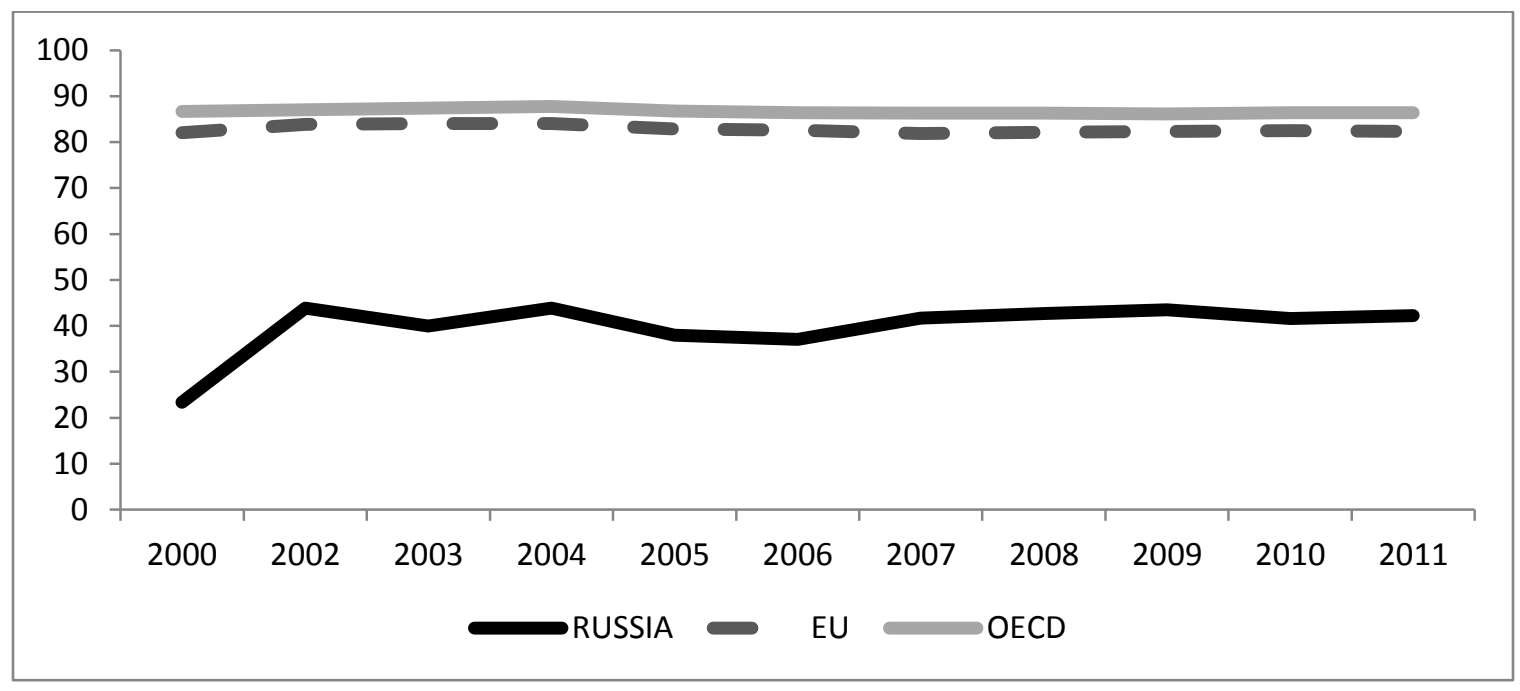

Figure 5 prepared by author using data from Governance Research Indicator Country Snapshot.

The data reveals continuity of the trend for the Russian Federation for almost the entire period of the reform, despite predictions of continuous increase in governance performance as stated in both conceptions. Shortly after a rather rapid increase in perceptions of efficiency of Russian public administration of the early 2000s, which was perhaps driven by Putin's political reforms (discussed in Chapter I), the index stabilised at the score of 41 . For the period of reform the average score of Russia is 41.2. That is significantly lower than the average indices of governance efficiency calculated for the OECD and EU countries.

The 2005 Conception (including the 2008 amendments) mentioned the Growth Competitiveness Index (GCI) prepared by the World Economic Forum stated that Russia's performance was not only quite low among all researched countries; it also showed a declining trend. Appendix V presents Russia's global performance in regards to several governance indices. Russia's rankings have been quite volatile, however, it must 
be argued that Russia's place in the rankings has been changing due to the increase of the overall quantity of presented countries. If this factor is taken into an account it may be argued that Russia has been constantly placed in the lower third cluster of countries.

Due to methodological issues, it is more productive to analyze changes in the score, rather than Russia's placement in the ranking, as far as principles of analysis are relatively constant and provide a basis for timely analysis. Pointing out the business community as the primary beneficiary for improvement of governance creates a focus on several indices that help trace successfulness of reformatory attempts in decreasing government's penetration into economic life. For the current presentation, two indices were chosen. These indices are: a) Burden of government regulation and b) Favoritism in decisions of government officials. Figure 6 presents Russia's annual performance with respect to these indicators in a scale from 1 (signifying most negative impact) to 7 (signifying most positive impact). Both indices are presented alongside more the general Growth Competitiveness Index.

Figure 6. Business indicators of performance of Russia's public administration.

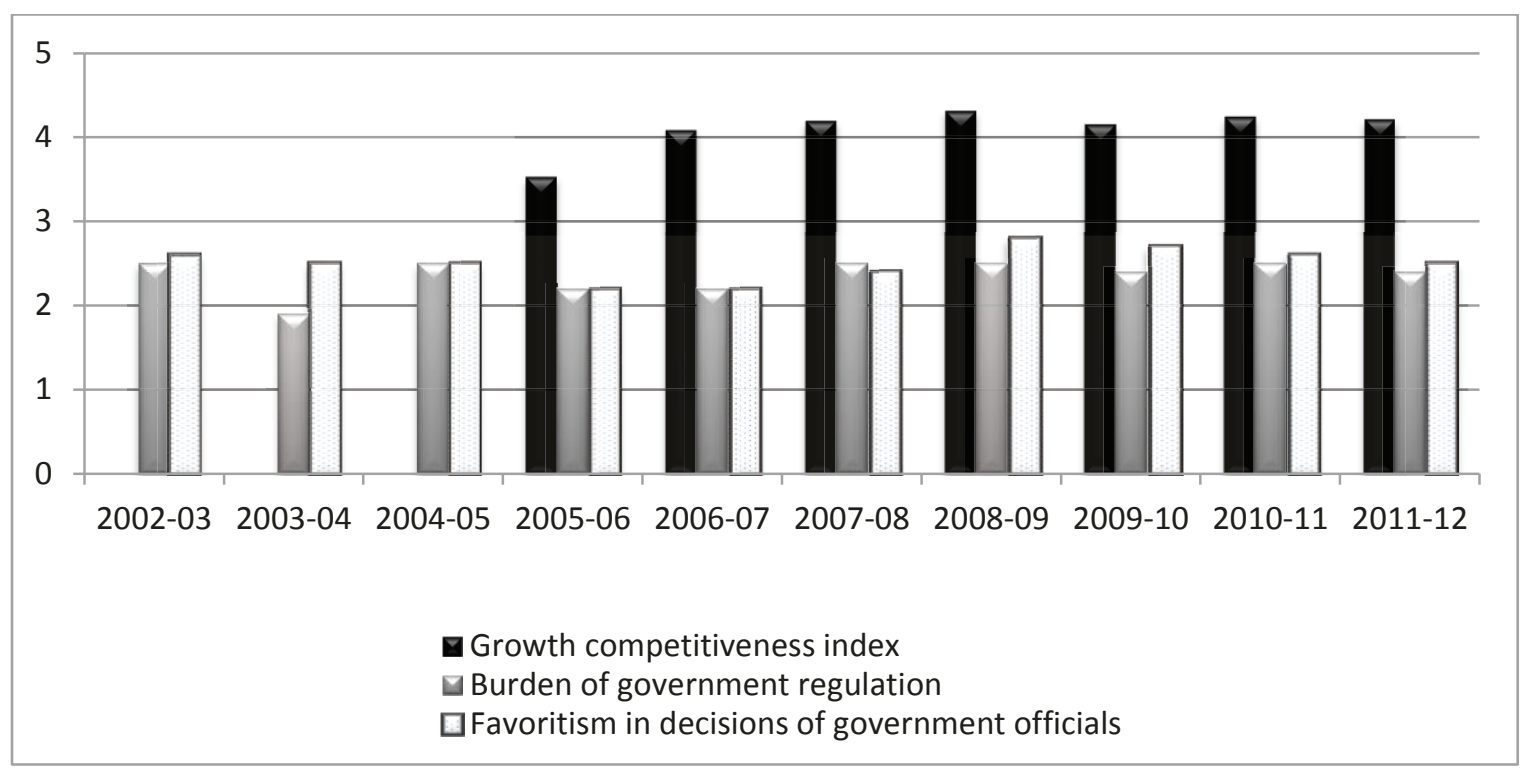


(Figure 6 is prepared by author using data from Global Competitiveness Index Report) (11 $^{51}$

Analyzing this chart, it can be argued that in regards to an improvement of governance in the sphere of economic policies, the reform did not provide expected results. The expected improvement of Russia's rankings, as was indicated in both Conceptions, was much higher than the actual scores. It is very important to mention that these indicators were chosen by the reformers themselves and thus even with respect to their own benchmarks, the successfulness of the reform may be questioned. Moreover, in regards to all international indicators, Russian public administration did not show feasible signs of improvement neither during the first, nor during the second stage.

Table 2. Russia's position in the Global Competitiveness Index Report Survey (selective indexes)

\begin{tabular}{|c|c|c|c|c|c|c|c|c|c|c|}
\hline \multirow[b]{2}{*}{ year } & \multirow[b]{2}{*}{$\begin{array}{c}\text { No. of } \\
\text { countries }\end{array}$} & \multicolumn{2}{|c|}{$\begin{array}{c}\text { Growth } \\
\text { competitivenes } \\
\text { s index }\end{array}$} & \multicolumn{2}{|c|}{$\begin{array}{c}\text { Burden of } \\
\text { government } \\
\text { regulation }\end{array}$} & \multicolumn{2}{|c|}{$\begin{array}{c}\text { Transparency } \\
\text { of } \\
\text { government } \\
\text { policymaking }\end{array}$} & \multirow[b]{2}{*}{$\begin{array}{c}\text { No. of } \\
\text { countries }\end{array}$} & \multicolumn{2}{|c|}{$\begin{array}{l}\text { corruption } \\
\text { perception } \\
\text { index* }\end{array}$} \\
\hline & & place & $\begin{array}{c}\text { score } \\
1-7\end{array}$ & place & $\begin{array}{c}\text { score } \\
1-7\end{array}$ & place & $\begin{array}{c}\text { score } \\
1-7\end{array}$ & & place & $\begin{array}{c}\text { score } \\
1-10\end{array}$ \\
\hline $\begin{array}{l}2002- \\
03\end{array}$ & 80 & 64 & & 46 & 2.5 & 70 & 2.6 & 102 & 71 & 2.7 \\
\hline $\begin{array}{l}2003- \\
04\end{array}$ & 102 & 70 & & 100 & 1.9 & 97 & 2.5 & 133 & 86 & 2.7 \\
\hline $\begin{array}{l}2004- \\
05\end{array}$ & 104 & 70 & & 77 & 2.5 & 92 & 2.8 & 145 & 90 & 2.8 \\
\hline $\begin{array}{l}2005- \\
06\end{array}$ & 117 & 75 & 3.53 & 110 & 2.2 & . & . & 159 & 126 & 2.4 \\
\hline $\begin{array}{l}2006- \\
07\end{array}$ & 125 & 62 & 4.08 & 116 & 2.2 & . & . & 163 & 121 & 2.5 \\
\hline $\begin{array}{l}2007- \\
08\end{array}$ & 131 & 58 & 4.19 & 118 & 2.5 & 118 & 3.1 & 180 & 143 & 2.3 \\
\hline $\begin{array}{l}2008- \\
09\end{array}$ & 134 & 51 & 4.31 & 118 & 2.5 & 119 & 3.2 & 180 & 147 & 2.1 \\
\hline $\begin{array}{l}2009- \\
10\end{array}$ & 133 & 63 & 4.15 & 124 & 2.4 & 114 & 3.5 & 180 & 146 & 2.2 \\
\hline
\end{tabular}

${ }^{51}$ The data for Figure 6 was collected from the annual Global Competitive Index reports 2002-2012. For more details please refer: World Economic Forum (2002-2012). Global competitiveness report. Geneva: World Economic Forum. 


\begin{tabular}{lllllllllll}
\hline $\begin{array}{l}\mathbf{2 0 1 0} \\
\mathbf{1 1}\end{array}$ & 139 & 63 & 4.24 & 128 & 2.5 & 105 & 3.8 & 178 & 154 & 2.1 \\
$\mathbf{2 0 1 1 -}$ & 142 & 66 & 4.21 & 132 & 2.4 & 115 & 3.7 & 183 & 143 & 2.4 \\
$\mathbf{1 2}$ & & & & & & & & & & \\
\hline
\end{tabular}

* Corruption perception index is calculated by Transparency International (Table 2 is prepared by author using data from Global Competitiveness Index Report) ${ }^{\mathbf{5 2}}$

Looking at other international governance related indexes such as "Wastefulness of government spending" and "Transparency of governmental policymaking" (both from Global Competitiveness Report), as well as the Corruption Perception Index (Transparency International), it becomes evident that with respect to the international standards, the reform of public administration in Russia did not improve the performance of the governmental structures.

The given statistical outcomes also lead to a question regarding the substantial shift in the top priorities of the reform from economic deregulation and promotion of economic development to internal optimization and provision of public services. As the given indicators revealed, no substantial improvement, with respect to the initial objectives to optimize government's penetration in the economy, has been achieved. In these circumstances, the shift of the focus of the reform from improving the economic performance of the country to improving the quality of public services provision that occurred with adoption of 2011 cannot be approved. Moreover, it evidences a separation between the technology of setting the objectives of the reform from the actual process of policy implementation. The review of performance indicators reveals that the decadelong reform of public administration in Russia has so far not been able to provide substantial changes to the performance of institutions of the state.

${ }^{52}$ Ibid. 


\section{Conclusion}

This chapter investigated the process of the reform of public administration and civil service in Russia from 2002 until 2013. One of the research assumptions of this dissertation stated that the process of the reform itself might have some negative impact on the process of modernization of public administration, and might contribute to its failure. In none of the objective quantitative parameters did the reform achieve its objectives. The reform could not improve Russia's position in international ratings of countries. In some instances, such as the governance index, or the index of corruption, the situation even worsened. With respect to some other indices, Russia showed some moderate improvements. However, its performance was significantly lower than was expected. Institutional transformations and adoption of the three-layer system of the federal executive organs were not implemented to their logical conclusion. Although, the three-layer system was not abandoned, as was suggested by some critics, its performance cannot be considered fully satisfactory. As one of the key designers of the reform stated in an interview:

...the instalment of the three-layer structure only fostered chaos and disorganization. Positive effects appeared to be minimal. The very idea of the three-layer structure was discredited because it was implemented in case of the state apparatus, which efficiency had been low regardless of any [possible] institutional framework [it could be given]. ${ }^{53}$

It cannot be stated that the new structure improved the stability of the public administration in institutional terms. Indeed, it limited the variety of institutional forms that could be applied to institutions. Since its adoption, existence of the three-layer structure of government has never been the subject of open political debate. Excluding a

${ }^{53}$ Petr Fillipov and Tatiana Boiko (2010). Administrativnaia reforma. Interv'iu s M.E. Dmitrievym.(Online). [URL: http://www.ru-90.ru/node/58] (Accessed June 29, 2013). 
rather short period, when the state committees were revived and later abandoned, the very principle of separation of political, controlling and administrative functions of the state has not been compromised. However the institutional volatility (e.g. rearrangements of institutions within the given framework) remained rather high. State functions were moved not only horizontally (from one ministry, agency, or service to another) but also vertically (say, from agency to service, etc.). Therefore, throughout the post-instalment decade, the situation in the federal public administration remained rather turbulent.

The idea to begin the reform with the introduction of a new structure of public institutions did not prove itself to be effective. It was expected that this approach will allow public officials to gradually adapt and improve the functional capacity of the new structure over the subsequent years and finally, completely distinguish political, controlling and administrative functions. Instead, ministries continued controlling the entire hierarchy of public institutions in the sphere of their authority. Focusing on the structural aspect is not ultimately fallacious; however, in the Russian case, this did not produce the desired results. Although the three layers were designed to be functionally independent, the actual practice revealed evidence of hierarchical subordination of both services and agencies to ministries or the government apparatus. At this point, a hypothesis that explains the reasons why the institutional approach did not work could be raised. It can be assumed that the reformers reserved for themselves a significant degree of freedom to introduce necessary adjustments to the system of government institutions instead of, for example, constituting the three-layer system and the nomenclature of government institutions in the form of a federal law. However, preserving the freedom to 
introduce changes, the ruling elite did not enhance vigilance over the efficiency of structural changes they impose on the system.

This argument can be extended to other aspects of implementation of the reform of public administration. In order to improve procedural flexibility and have the ability to introduce immediate changes to the program of the reform, it was decided to issue reform agendas in the form of by-laws, presidential Decrees and governmental resolutions. At the same time, it must be pointed out that the nomenclature of laws and by-laws that were adopted in order to form the proper legal framework for the reform was substantial. However, all these changes have not resulted in a qualitative improvement of the situation in the sphere of governance. The major indicators revealed no progress in the development of public institutions in Russia. In some instances, there were even signs of degradation. The given situation leads to an agreement with the famous aphorism that the "severity of Russian laws is compensated by optionality of their execution." The reformers wanted to preserve procedural flexibility not only over the process of reforms. They also wanted to maintain their ability to easily introduce changes to the structure of public administration, changing the institutional composition of the Cabinet. As was stated elsewhere: "it would be well to legally affirm the typology of institutions and organizations of executive power. ${ }^{, 54}$

The structural approach to public administration remained dominant in the logic of the reform. In this regard the reform process in Russia deviated from the major trend in modernizing public administrations on the basis of the managerial paradigm. It is more common to make adjustments to the system of public institutions as a result of a revision

\footnotetext{
${ }^{54}$ Viktor Vishniakov (2011). "Administrativnaia reforma: 15 let poiskov kontseptsii." Zakonodatel'stvo i ekonomika, 2011, No. 7, p.10.
} 
of duties and responsibilities of a public administration. Yet Russian reformers emphasized the importance of the introduction of proper institutional framework. Although being contradictory to managerial reforms, this idea, in principle, followed the trend of conduct of the reform on the basis of the doctrine of the 'power vertical'.

Overall, it can be concluded that the proposed principles of implementation of the chosen design of the reform did not match its expectations. As in the case of the federative reform, the vertically integrated public administration followed the instructions of the president, and retransmitted the commanding principle of conducting the reform to the bottom of administrative hierarchy. Willingness of public officials to limit the participation of non-government agents in the reform process also played its negative role. With a lack of public control over the reform process, the bureaucratic apparatus was able to downgrade the influence of various interest groups on the reform process and ignore corrections and improvements proposed by them. 


\section{Chapter V. Implementation of policies: the reform in the sphere of civil service}

Introduction: civil service reform as an independent modernization project.

Obviously, the reform of public administration in Russia could not be completed without substantial modernization of the state apparatus. The officialdom not only should overcome the legacies of the Soviet past, but also substantially advance its capacity to perform in a new socio-economic environment. As it was witnessed in Chapter 2, during the first post-Soviet decade, the situation in this sphere had been gradually deteriorating. Therefore, in the early 2000s Russian officialdom was showing signs of degradation in almost all aspects: from overall understaffing and demographic and gender disparities to a drastic decay of professional characteristics of the civil service in terms of education, remuneration etc. ${ }^{1}$ In addition, low perception of quality of the public service from the point of view of the population, and common public discontent with the class of bureaucrats, negatively affected the prestige of this type of labour, discouraging the inflow of new cadres.

Russian academic tradition treats the reform of civil service as an independent project; and first two stages of the reform supported this approach. The reforms of public administration and civil service were separated chronologically, conceptually, as well as in terms of the implementation process. It must be mentioned here that the first steps to modernize the system of governance in Russia were made in the sphere of civil service.

${ }^{1}$ This statement was supported not only by the academic community (see for example: A. Barabashev, J. Straussman. "Public Service Reform in Russia, 1991 - 2006." Public Administration Review, May-June 2007 pp.373-382), but also by reformers themselves, as they pointed out all these issues in the preamble to the Federal Targeted Program "Reforming the state service in the Russian Federation in 2003-2005". 
The tentative plan of the reform was institutionalized in the form of the Conception of the Reform of State Service in $2001,{ }^{2}$ almost two years prior to institutionalization of the ideology, methodology, and the implementation strategy, of the reform of public administration. At the same time, the idea that both reforms are parts of a similar project was already posited in this document. It was stated in the 2001 Conception that "[t]he formation of the system of civil service is being implemented in stages and gradually, on the basis of specific programs, financial and resource support, taking into account national as well as foreign experience that was adopted to the Russian realities, in accordance with the approved plan of first-priority measures, and in concordance with the public administration reform, the military reform and the reform of the judicial system."” Although correspondence of both reforms was recognized from the very beginning, they were reunited only after a decade of reforms during the third phase. In the governmental resolution No. 1021-r of June 10, 2011 was stated that "meaningful intersection of the given reforms in terms of measures, ideology and approaches does not allow any more to separate them on distinct particular reforms."

Different governmental agencies were assigned for managing and controlling the implementation processes of both reforms. Whereas institutions of the Russian Government (in particular a special Intradepartmental Government Commission and the Ministry for Economic Development and Trade) were commissioned to conduct the reform of public administration, the Presidential Administration was made responsible

${ }^{2}$ Decree of the President of the Russian Federation No.1496-Pr from August 15, 2001. "Kontseptsiia reformirovaniia gosudarstvennoi sluzhby Rossiiskoi Federatsii."

${ }^{3}$ Ibid.

${ }^{4}$ Resolution of the Government of the Russian Federatrion No/ 1021-r from June 10, 2011. "Kontseptsiia snizheniia administrativnykh bar'erov i povysheniia dostupnosti gosudarstvennykh i munitsipal'nykh uslug na 2011 - 2013 gody." 
for the civil service reform. Quite obviously, such separation had its effect on desynchronization of the reform process. Chapter 2 evidently showed that in the years since adoption of the Constitution the Presidential Administration has become a very powerful political institution and its activities grew beyond its initial role of ensuring activities of the President. Presidential Administration became an alternative center of power, as it develops policies and conducts political programs on behalf of the President. Quite obviously, the political influence of this institution contributed to the fact that it independently conducted policies and reforms that were assigned to it. In some cases, the Presidential Administration established a viable alternative to the Federal Government in the sphere of policy development. ${ }^{5}$

The depth and scale of modernization of the system of governance were considered as the reasonable explanation for separation of both reforms in the early stages. In reality, this approach might also have contributed to the way both reforms were implemented. Quite obvious is the fact that both the civil service and public administration constitute two mutually dependent aspects - human resources and administrative institutions respectively - of the system of government in the country. Their conceptual, and more importantly, procedural segregation would impede congruence of implementation of the entire project of reforming the system of government in the country.

The logic of the argument in this dissertation research objects to the idea of separation, both procedural and conceptual, of the civil service reform from the reform of public administration. It is posited in the research that the depth of transformation of the

${ }^{5}$ See for example: Konstantin Frumkin (2013) "Sverkhministry." Kompaniia. No.7 (240). 
system of government in Russia demands significant attention to the process of reform. Therefore, any procedural complication, such as the organizational separation of public administration and civil service reforms, is deemed potentially disruptive.

Yet the reform of civil service is analyzed in this research as a distinct project, i.e. in accordance with the logic of the reform process. In accordance with the process-tracing methodology, adopted in this research, such an approach provides analytical tools for the deconstruction of the process of reform, establishment of its crucial features and analysis of their correspondence (or otherwise disconnection) with other reforms of the government.

Since its launch in 2002 the reform has undergone through three phases. This research firstly investigates most important innovations in the sphere of civil service that were introduced at each stage and afterwards, assesses what outcomes, both positive and negative, these innovations produced. As the research hypothesis for this dissertation states, the process of the reform itself is a factor that could contribute to the failure of the reform. At the same time, it is quite obvious that failures in modernization of civil service could not help but affect outcomes of the reform of public administration. Therefore, civil service reform, regardless of its distinction from public administration reform is considered in this research as a sort of supplementary independent variable that contributes substantially to understanding of the major object of research.

The reform of the public service is a quite complex endeavour. It has included a set of quite versatile measures. Some of them were fundamental and radical; others routine and incremental. In addition, working on the plan of reform and its methodology, reformers adhered to the structural perspective. They started from establishment of a 
taxonomy of various forms of public (or state, as they called it) service. ${ }^{6}$ The reform distinguished three types of the public service in Russia: civil service, military service, and law-enforcement service. Such a specification of public service was a rather unique feature in the praxis of modernization of the legislature on public service that has had a substantial effect of the process of reform in Russia.

Each type of public service was the subject of a distinct reform. The reform of state civil service (hereafter civil service) was launched in 2002, shortly after this taxonomy was established. Military and law-enforcement reforms were postponed for several years and began in 2008, at the start of Dmitry Medvedev's presidential term. Consequently, this Chapter will focus solely on the reform of state civil service, as far as it has been conducted independently of other reforms of state service. Moreover, the objectives of this chapter allow us to focus exclusively on the most politically remarkable innovations and analyze how they are related to the chosen managerial paradigm of the reform. This Chapter, therefore, discusses the process of reform implementation, its major stages, as well as achievements.

\section{The decade of the reform: concepts and their implementation}

The formal beginning of the reform of civil service can be dated to November 19, 2002, when president Putin signed Decree No. 1336, titled the "Federal targeted program of the reform of state service in 2003-2005". The particular reform that began in the country in the early 2000s differed substantially from all previous attempts, as "individual theoretical developments and unsystematic practical actions had been

${ }^{6}$ See Federal Law No.58-FZ of May 27, 2003 "O sisteme gosudarstvennoi sluzhby Rossiiskoi Federatsii." 
substituted by consecutive efforts performed on the basis of a unifying conception." ${ }^{77}$ The above mentioned federal program, as well as the second "Federal program of the reform and development of state service (2009-2013)" ${ }^{\prime}$ were based on the "Conception of the reform of the system of state service" ${ }^{\prime 9}$ (hereafter Civil Service Conception). These three documents constitute the fundamental normative and legal background of the reform.

There were several scholarly attempts of clusterization of the reform process, including classifications of actions, undertaken during it. Some scholars prefer treating the current reform as a logical continuation of the 1990s reformatory attempts. ${ }^{10}$ Some others, like Aleksey Barabashev, consider the current reform as a separate reform project that was designed and implemented during the presidencies of Vladimir Putin and Dmitry Medvedev. Analyzing implementation of the reform, Alexei Barabashev outlines three consecutive stages. ${ }^{11}$ Each stage is driven by one major objective, or, as he calls it, dominant. During the earliest stage (he dates it between 2000 and 2005), the dominant was the modernization of normative and legal framework of new public service. The second stage that accounts the period between 2005 and 2008 was aimed at the "development of technologies of functioning of the new public service within the

\footnotetext{
${ }^{7}$ Aleksei Barabashev (2013) Evolyutsiia gosudarstvennoi sluzhby Rossii: itogi desiatiletiia (2000-2010). Moscow: HSE., p.18

${ }^{8}$ Decree of the President of the Russian Federation No.261 of March 10, 2009 "O Federal'noi programme "Reformirovaniie i razvitiie sistemy gosudarstvennoi sluzhby Rossiiskoi Federatsii (2009-2013)"”.

${ }^{9}$ Decree of the President of the Russian Federation No.1496-Pr from August 15, 2001. "Kontseptsiia reformirovaniia gosudarstvennoi sluzhby Rossiiskoi Federatsii."

${ }^{10}$ See for example: Aleksandr Obolonskii, (ed.) (2009). Gosudarstvennaia sluzhba (kompleksnyi podhod). Moscow: 'Delo'., Chapter 5.

${ }^{11}$ Alexei Barabashev (2013) Evoliutsiia gosudarstvennoi sluzhby Rossii: itogi desiatiletiia (2000-2010). Moscow: Higher School of Economics
} 
[established] normative and legal framework." ${ }^{12}$ The final stage includes the period between 2009 and 2013 and is aimed at practical implementation of these technologies, which were developed during the previous stage.

It is obvious that in Barabashev's taxonomy first and second stages correspond with the duration of the first federal targeted program; and the last stage is fully covered by the second one. In this regard, the second program was the logical consequence of the first one. Therefore, its agenda almost entirely repeated the set of desired reform outcomes, proposed in the earlier program. Most of the objectives were rephrased in order to address the desire of reformers to finalize the reform by the end of the scheduled deadline in 2013. Yet, some goals were repeated almost exactly. Among such objectives should be mentioned the need to improve openness of the public service and its accountability to civil society and citizens. Therefore, Barabashev's approach puts the reform of civil service strictly in line with the public administration reform, as they share ideological premises of the New Public Management doctrine, and the set of measures, proposed for the civil service reform, follows the changes in the sphere of public institutions. In other words, the reform of civil service was scheduled in such a way that public officials adapt to the changes in the system of public organization that have been introduced during the public administration reform.

This dissertation adopts a slightly different approach to the chronological categorization of the reform, in order to synchronize the logic of the argument with that developed in the previous chapter. In principle, it follows the logic of Aleksey Barabashev and considers early 2000s as the time of reform's beginning. Therefore, it

${ }^{12}$ Ibid. p. 35. 
understands the current reform as a separate project, not a continuation of the 1990s attempts. At the same time, the process of reform is grouped according to a different logic. It follows the logic of the reformers, as they separated the reform process by means of legal documents.

There could be outlined three major phases of the reform. The first phase covers all preparatory measures. It lasted for two years from 2001 till 2003. During this phase, theoretical, conceptual, and ideological parameters of the reform were elaborated, and necessary changes to the legislature were introduced. One of the cornerstone results of this stage was the passing in 2004 of the radically new laws: "On the system of state service" (No. 58-FZ) and "On the state civil service" (No.79-FZ). Adoption of these laws was a quite significant factor for the future development of the institute of civil service in Russia.

The second phase covered four years (initially from 2003 till 2006; later extended until 2008), and was primarily dedicated to the adaptation of new principles and relations in the sphere of public service. For this phase, a set of measures was proposed that covered a variety of issues: from installment of new principles of organization of work to new recruitment policies, as well as improvement of openness and responsiveness of the state apparatus. These measures were united in the form of the federal targeted program.

The third stage of the reform was scheduled to be accomplished during 2009 and 2013. Its major objective may be described as the creation of a holistic system of management of the entire sphere of public service. As in the previous stage, this one was also organized in the form of a specific federal targeted program. According to this program that synthesized all reformatory measures and was titled "The reform and 
development of the system of the state service of the Russian Federation (2009-2013)," this phase must accomplish a decade-long project of the reform of public service in the country. ${ }^{13}$

Besides the chronological approach, the reform measures can also be grouped on the grounds of three major parameters: ideology, goal-and-program setting, and organization of the reform process. ${ }^{14}$ This approach allows to focus on the substantial characteristics of the reform and, at the same time, to avoid excessive and unnecessary (for the purposes of current study) detailed elaboration.

The ideology of the reform was based on the notion of necessity to overcome the legacy of the previous system of government, on the one hand, and on the normative understanding of how the new system should look like, on the other. In this respect, the reform of public service matches the ideological premises of the reform of public administration. Such characteristics of the old system, as patronage and political biases, were stigmatized as obsolete and thus, should be overcome by the apparatus of the state in order for it to be able to successfully perform modernization of the country. At the same time the future bureaucratic apparatus was seen as a rather eclectic construction that fused characteristics of a Weberian-type rigid traditional bureaucracy with a contemporary mobile and responsive public service. Therefore, the ideological orientation of the reform cannot be easily and unequivocally identified, if only its conceptual premises, as they were stated in the documentation, are taken into an account.

${ }^{13}$ Decree of the President of the Russian Federation No.261 of March 10, 2009 "O federal'noi programme "Reformirovanie i razvitie sistemy gosudarstvennoi sluzhby Rossiiskoi Federatsii (2009-2013 gody)"

${ }^{14}$ See : Aleksei Barabashev (2013). Op.cit. 
Another aspect of the reform of civil service, namely goals-and-program setting, included particular tasks and plans of measures of conducting the reform. This aspect reveals domination of the technocratic approach to implementation of the reform. For each particular objective the reformers elaborated a particular plan of measures. Yet, the descriptions of these measures were primarily focused on their final outcomes, not the process of the reform. As Alexei Barabashev pointed out: "issues of resources allocation, temporal framework, as well as the choice of the optimal sequence [of actions] and stimuli for progressive transformations had not been considered as a complex issue."15 The technocratic approach of the reformers determined negligence to the collateral processes and side-effects that the proposed measures could have (and in fact have had) on the success of the implementation of the reform measures.

At the same time, the goals-and-program setting aspect had a somewhat positive impact on implementation of the reform. The approach allowed reformers to designate quite clear and exact policy measures and formalize them in the form of presidential decrees, thus making them mandatory for fulfillment. However, the existing forms of administrative control over execution of presidential decrees are focused predominantly on the formal aspects and not on a complex assessment of efficiency of the entire process of implementation. This characteristic, to some extent, contributed to low efficiency of the proposed reform measures.

Organization of the process of reform is the third important aspect. It was primarily aimed at establishment of a complex management system of state service. Such system has not been established yet, regardless of the fact that its parameters have

${ }^{15}$ Aleksei Barabashev (2013). Op.cit., p.22 
constituted in the law since $2003 .{ }^{16}$ The reform process itself was subject to delays, due to the need of coordination and consideration of the interests of all concerned agencies, ultimately making the entire reform process sluggish and unresponsive to changes of the social and political environment.

Therefore, if temporal allocation of the reform measures reflects the logic of gradual, yet, at the same time, substantial transformation of the Russian officialdom that urgently needed modernization (as it was presented in the documentation); their categorization according to the reform's parameters raises some rather important issues. First of all, the organization of the process of reform proved to be inefficient. It not only separated both reforms of public administration and the state service; but also within the reform of civil service the decision-making process has not been fast and efficient. Secondly, the reform's agenda, or at least the way it was documented, may be considered superficial. Lack of attention to details and primary focus on proper description of the final objectives proved to be insufficient. And, finally, its ideological premises have not been consistent. The reform's approach tried to accumulate potentially incommensurable ideologemmes and the reformers proposed some measures that contradict to the logic of "overcoming the Soviet legacies." Therefore, it is quite important to consider the program documents of the reform of civil service, in order to establish contradictions they contain.

The 2001 Conception of the reform of public service posited that the primary objective of the forthcoming transformations of the bureaucratic apparatus should be the improvement of efficiency of the state apparatus for the sake of the "interests of

${ }^{16}$ See: Federal law No. 58-FZ, from May 27, 2003 "O sisteme gosudarstvennoi sluzhby Rossiiskoi Federatsii", Article 16. 
developing civil society and strengthening the state. ${ }^{117}$ Accordingly, the chosen vector of the reform should result in the construction of a fundamentally new system of national bureaucracy, ideology of which should be the service to the public, not superior patrons of bureaucrats. In this regard, this vector emphasized the priority of the horizontal vector of the political process over the vertical one. Among the major characteristics of the future public service were mentioned: the independence of public officials from political parties, non-governmental and religious organization and economic agents. The 'serving the citizens, not the patrons' ideologemme was further enforced by the proclamation of equality of all citizens in their access to public services, as well as openness and publicity of the public service itself. The entire Section 3 of the 2001 Conception was devoted to issues of interactions and cooperation between the bureaucratic apparatus and civil society.

The improvement of efficiency of civil service was correlated with the introduction of "modern technologies of governance that included new methods of planning and financing activities of federal governmental agencies." ${ }^{\text {18 }}$ Those methods were discussed in the previous chapter of this dissertation; and they can be related to the managerial paradigm. However, at the same time, new principles and technologies of public human resources management were more related to the classical model of bureaucracy.

\footnotetext{
${ }^{17}$ Order of the President of Russia No. Pr-1496 from August 15, 2001 "Kontseptsiia reformirovaniia sistemy gosudarstvennoi sluzhby Rossiiskoi Federatsii".

${ }^{18}$ Decree of the President of the Russian Federation No.1336 of November 19, 2002 "O federal'noi programme reformirovaniia gosudarstvennoi sluzhby Rossiiskoi Federatsii (2003-2005)."
} 
The 2001 Conception established the agenda of the reform, outlined its ideological contours and those aspects of public life that needed administrative oversight. The detailed plan of reorganization was presented later on the basis of two federal targeted programs. The first federal targeted program, which was released in 2002, described challenges that Russian officialdom had already faced or would face in the nearest future. Among the most important ones it mentioned the reduction of quality of public service that was the result of the decreasing level of professionalism of public officials, mainly due to their low income and absence of clear and widely accepted ethics, as well as low social esteem of their work. It was stated in the program that should these tendencies continue, the Russian system of civil service would be unable to perform its duties and would become an impediment to social and economic development of the country.

In order to overcome the negative trends, the federal program prepared a set of measures. Some of them corresponded directly with measures proposed in the public administration reform. These were: reorganization of internal bureaucratic processes in accordance with introduced administrative regulations; and establishment of new principles of planning and financing, as well as modernization of the system of stimuli for improvement of efficiency of civil service. Other measures were unique and pertained to the reform of civil service exclusively. Apart from optimization of the legal and normative aspect of the state administration, these measures included: development of new cadre policies and reestablishment of the social status of civil service.

The second federal program, scheduled to be accomplished between 2009 and 2013 was predominantly focused on the establishment of a complex management system 
of civil service. This process demanded unification and standardization of principles of conducting the state service, as well as creation of specialized administrative bodies that will be responsible for managing the system of public service in the country.

In terms of organization of the reform process, both programs emphasized the need to reverse the 'incremental' approach to reform that was dominant during the 1990s and proposed radical changes of the very essence of the Russian bureaucracy. The reformers believed that in order for the system of public service to overcome the legacies of its Soviet past, it needed a rather radical set of reforms. The review of the condition of the public service, presented in the beginning of the first federal targeted program, clearly indicated that the Soviet administrative practices had plagued the Russian officialdom for the entire first post-Soviet decade.

Analyzing the entire nomenclature of normative and legal documents, prepared for the reform, it may easily be noticed that the reformers adopted a normative approach. They focused predominantly on the description of how system of civil service should look like after the completion of the reform. Description of the final results dominated in the papers. Although the programs of reform included special appendices, which listed measures that must be undertaken in the course of the reform, as well as allocated budget funds, the overall description of those measures could not be considered exact. Moreover, the Conception did not specify the mechanisms of involvement (or at least control) of the institutions of civil society in the reform process.

First results of the reform: optimization of the quantity of public service.

The 2001 Conception of the reform provided evidence that the system of public administration in Russia needed modernization in almost all segments. Yet a few of them 
were critical and demanded special attention. First of all was the issue of quantity of public servants. Secondly, the reform outlined the need to establish new principles of cadre policy. And thirdly, the reformers emphasized measures aimed at consolidation of the corporatist culture and improvement of the social status of public service, as well as the ethical standards of work of public officials.

The size of the state apparatus is the most politicized aspect of the reform, as far as politicians argue for the need of reduction of the quantity of public officials each time they refer to the reform of civil service. The reformers, however, were not so unambiguous and instead spoke of not the reduction, but rather optimization, of quantity of public officials. In the following paragraphs this aspect of the reform will be discussed. After that another section of the chapter will be devoted to the other two dimensions of the reform.

Figure one shows the dynamic of quantity of public officials in Russia throughout the years of the reform. The data indicate an increase of the quantity of employees as a result of implementation of the reform measures. In the first five years, the quantity of public officials increased by 29.1 percent. Beginning in 2009 , there can be observed a trend to slightly depopulate the public service. Although the downward trend coincided with the growth of concern of the political elites regarding the expansion of the public service, it nevertheless should be linked with the consequences of the world financial crisis of 2008-2010. Regardless of all proclamations made by politicians, the quantity of public officials remains 18.3 percent higher than it was at the beginning of the reform. The growth of the state apparatus is even slightly more evident if we compare it with the general demographic trend in the country in the first decade of the $21^{\text {st }}$ century. The 
quantity of bureaucrats per 10000 individuals increased from 90.2 in 2003 to 109.7 in 2012 with the peak growth of 118 bureaucrats observed in 2009. This shows a total growth of 21.6 percent. In other words, the state apparatus was growing slightly faster than the nation itself.

Figure 1. The quality dynamic of public officials employed by the federal institutions of executive power (thousands of employees).

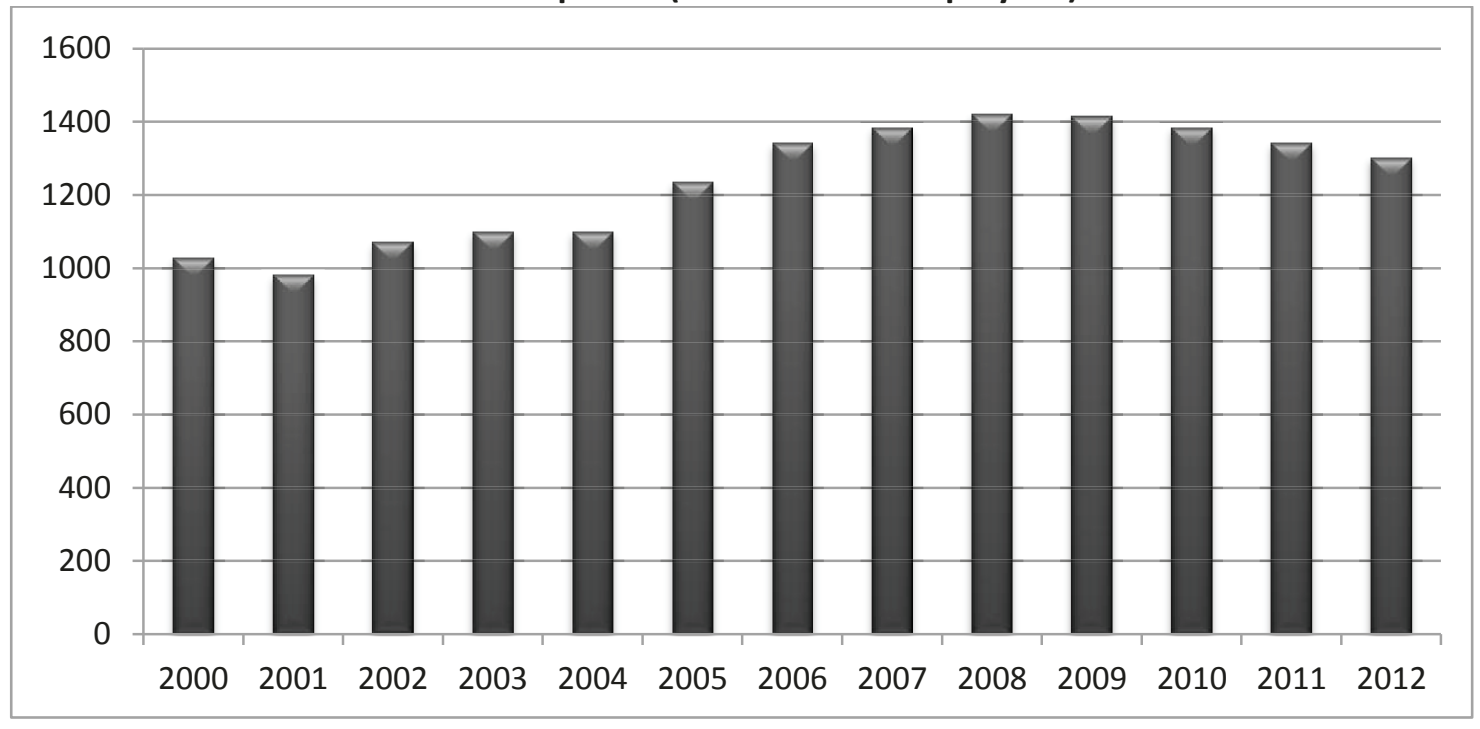

Figure 1. is prepared by author on the basis of Rosstat (Russian Statistical Agency) data.

As Figure 2 evidently shows, the major dynamic occurred at the level of federal government. ${ }^{19}$ Regional governments showed some marginal increase in quantity of employed officials as a result of the reform. Yet the municipal level remained mainly intact and stable throughout the reform.

The quantity of public servants is one of the most politicized issues of almost every reform of public administration regardless of the cultural or geographic specificities. It is common among the general public, as well as politicians, to express concerns over the size of the bureaucratic apparatus. The mainstream discourse consistently points to the need to curtail the size of state apparatus. Yet, there is no ${ }^{19}$ This statistic includes regional branches of the federal institutions of executive power. 
unequivocal understanding of the expectations of the reformers in Russia regarding this issue. On the one hand, politicians proclaimed a reduction of the quantity of bureaucrats as a necessary aspect of the success of the reform. ${ }^{20}$ On the other hand, program documents stated that the ratio of the quantity of public officials per 1000 of population is much lower in Russia than in such developed countries, as the USA and the United Kingdom. Therefore, the reform should increase the quantity of public officials; and as the data suggests in this regard, the reform was able to improve the ratio by 28 percent with regard to the general population, and by 24 percent with regard to the economically active part of the nation.

${ }^{20}$ In December 31, 2010 Dmitry Medvedev, then President of Russia signed a Decree No. 1657 "Ob optimizatsii chislennosti federal'nykh gosudarstvennykh grazhdanskikh sluzhashchikh i rabotnikov federal'nykh gosudarstvennykh organov". The document proclaimed a 2.5 year program of reduction of quantity of public officials by $20 \%$. Vladimir Putin also mentioned the need of reduction of the state apparatus. And some politicians like Boris Gryzlov, then leader of the United Russia party, directly linked the failure of the reform with inability to accomplish the goal of curtailment of the state apparatus. (See: I. Romancheva (2006). "Gryzlov: «Reforma provalilas'!»” Vzgliad, November 14. (Online) [URL http://www.vz.ru/politics/2006/11/14/57107.html] (accessed: June 10, 2013)). 
Figure 2. Quantity of public officials at the federal, regional and municipal levels (thousands of employees).

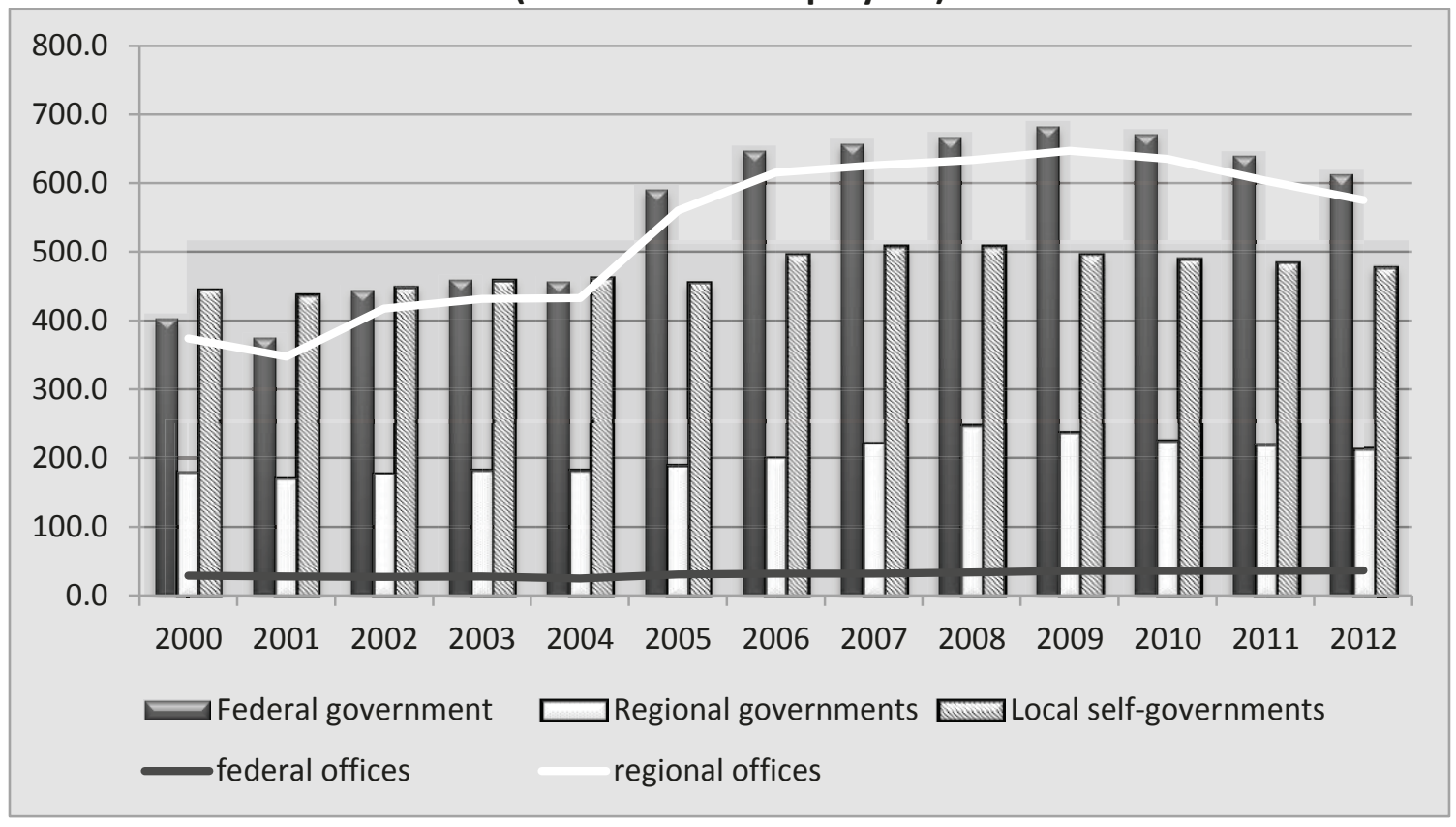

Figure 2. is prepared by author on the basis of Rosstat (Russian Statistical Agency) data

Although the quantity of public officials itself is an ambiguous indicator, the patterns of growth of the state apparatus allow us to suggest that the trend of vertical integration was the most prevalent. The federal level of government showed the highest rate of growth of its apparatus during the last decade, specifically since the beginning of the reform. At its peak in 2009, the quantity of public officials at the federal level was 33 percent higher than at the beginning of the reform. The growth was registered mainly in regional offices of the federal executive institutions, whereas the central offices expanded only slightly. Moreover, they also showed the lowest rate of reduction in quantity after the peak of 2009. Instead, in 2012, the central offices showed their highest ever index of employment. All other levels of government - regional offices of federal agencies and regional and municipal executive institutions showed a considerable decline in size of their staff. This decline should be explained not only through initiatives of political 
leaders, but also as the consequence of the economic recession in result of the 2008-2010 global economic crisis. Also, the federal level institutions showed lower rates of decline of the quantity of employed public officials than their regional counterparts (10 percent in comparison to 13 percent respectively).

Yet, the consolidation of the federal executive institutions is a rather remarkable event. Overall, the growth of the quantity of personnel symbolizes the domination of the federal authorities and indirectly supports the principle of the power vertical: if the decisions are made at the top, then servicing the decision making process demands more resources. The given situation with the personnel allocation at the federal level serves as an important contribution to understanding factors that contribute to the inefficiency of NPM driven measures during the reform of the public service and public administration.

To further display the case, it is important to pay attention to other pressure points of public service that were outlined in the federal program of reform for 2003-2005. Speaking of the conditions of the pre-reform public service, the reformers specifically focused on age and gender imbalances, as well as on the lack of professional mobility among public officials. It was stated that approximately 70 percent of all public employees in Russia in 2002 were female. The recorded average age was 40 years. Almost a quarter of officials had served no less than 15 years, and another 30 percent had a record of 5-10 years of service. Besides, "there is a continuous tendency for an increase in the number of state employees whose professional education does not meet the criteria for the positions they have." ${ }^{21}$ All these indicators provided the trend for a potentially

${ }^{21}$ Decree of the President of Russia No. 1336 from November 19, 2002. "O federal'noi programme 'Reformirovanie gosudarstvennoi sluzhby Rossiiskoi Federatsii (2003-2005 gody)'." 
unhealthy bureaucratic system in the observable future and demanded immediate and conceptually deliberate steps in order to overcome them.

In order to assess the successfulness of the reform, it is relevant to trace the dynamics of the observed indicators in the following ten years since the beginning of the reform. In regards with gender and age distributions, the reform did not provide any significant changes. In $2011,{ }^{22}$ the average age of employees of the federal executive institutions was 39 , and women continued to dominate with a ratio of 70.2 percent. The longevity of service has also been increased in result of the reform. The number of employees with career lengths exceeding 15 years increased by 5 percent (totaling 30.5 percent). The number of employees with terms of service between 5 to 10 years slightly decreased to 25 percent of the total public service workforce. An interesting dynamic could be observed with respect to newly appointed workers (e.g., those who got their positions in the last 0-5 years). The data provided some evidence of the intensification of hiring as a result of the reform. If at the beginning of the reform, new employees constituted 29.4 percent of the total workforce, then in 2007 their number eclipsed at 37.2 percent. In subsequent years, this ratio showed a decreasing trend, and returned to the pre-reform value of 29.5 percent. This observation leads to a conclusion that regardless of the reform efforts, the overall social portrait of the civil service in Russia has not changed significantly as a result of the reform.

Some progress was also achieved with respect to an improvement of education and qualification of public workers. As a result of the reform, the quantity of workers with higher education (university degree or higher) improved 17 percent (from 71.7

22 The latest available official statistic provided by Rosstat. 
percent to 88.7 percent). Also, the quantity of employees, who enrolled for professional skills advancement programs increased more than twofold in comparison to the prereform years (from 10 percent in 2002 to 23.5 percent in 2011).

As we may see, from the operational point of view, the result of the reform of the public service could not be interpreted unambiguously as either successful or ineffectual. Among the positive aspects of the reform must be mentioned the improved regulation of the work process within the public service on the basis of administrative regulations, which were introduced in the course of the reform of public administration. The other positive aspect is the significant increase in salaries of public employees.

Paradoxes of the Reform: Cadre Reserve and consolidation of the corporatist culture

Although the introduction of formalization and competition into the hiring process was an important step towards a modern public administration, the creation of the cadres reserve bundled with it, was a rather controversial measure. It can also be inferred from the analysis that the reform was unsuccessful in promoting the horizontal, interdepartmental communication. Moreover, in several instances its results came into confrontation with some visions of the future of the public service that were proposed in the 2001 Conception. It was expected that the reform would reduce the dependence of public officials on various political forces - an idea that in one or another form was present in both ideological frameworks of Neo-Weberianism and New Public Management. However as the analysis states, the current system is prone to political domination. In the first instance extension of the vertical of power to the regional level resulted in domination in governors' positions of members of one particular political 
party - United Russia. Secondly, at the federal level, both the president and the primeminister, as well as some ministers of the government and other officials, have affiliations with the same political party. Although the partisanship of the top-level public officials does not contradict the major principles of modern public administration, the existence of some legal mechanisms to enhance compliance and loyalty of lower-level public officials, does. Among such instruments, the cadres reserve can be mentioned. Direct involvement of top-level public officials into the employment process promotes loyalty and conformism amongst the potential nominees to the cadre reserve lists. Therefore, deeper analysis of this innovation is imperative.

Further advancement of the legislative and regulatory frameworks of public service was considered as one of the top priorities of the reform. The law "On the system of state service of the Russian Federation" introduced two features that influenced the nature of the public service in Russia quite significantly. Article 11 formalized the 'cadre reserve' - a specific system of personnel management that introduced the so called short lists of the most advanced and promising managers that can be promoted to leading positions in various public agencies. The second feature was the introduction of the system of bureaucratic ranks and titles for civil servants. Both innovations were not only very significant in terms of how they reshaped the nature of public service in the country; they were very controversial as well. Some critics argued that introduction of these features not only contradicted the logic of modernization of public institutions, but also created fruitful soil for reassurance of authoritarian tendencies in the sphere of governance. Such negative appraisals of important features of the new system of public 
service demand thorough analysis, especially in regards to their relation to other, predominantly managerial, features.

Although the Cadres Reserve is not a pure innovation of the current reform, it nevertheless was given a new status and became a substantive feature of the personnel policy in Russia. The Cadre Reserve, as it is described in the law "On the system of state service of the Russian Federation", is an evolution of the 1997 "Presidential program of training of public management personnel for organizations part of the national economy." 23 The temporary program (it ended in 2007) was primarily focused on funded educational programs for managers of the middle and higher layers of public bureaucracy, and aimed at an improvement of the quality of the group of current and prospected executive officers. Beginning with the reform of the public service in 2003, the nature of the program was substantially reconsidered. Deterioration of the quality of public officials (which was discussed in details in the Program of the reform) demanded urgent measures in the sphere of personnel management. Therefore, the multilevel system of the cadres reserve was introduced. It included four levels: the federal cadres reserve, the cadres reserve of a federal institution of state, the regional cadres reserve, and the cadres reserve of a regional institution of government. In principle, the reserve itself resembles a database that contains information regarding applicants for governmental jobs who successfully passed the primary selection stage as a result of an open competition. At the next stage, potential candidates are ranked and selected by special committees. These committees are formed within each institution of government at both

${ }^{23}$ See: Decree of the President of the Russian Federation No. 774 of July 23, 1997 "O podgotovke upravlencheskikh kadrov dlia organizatsii narodnogo khoziaistva Rossiiskoi Federatsii" 
federal and regional levels. In addition to the departmental cadres reserves, there exists the so called 'presidential cadres reserve' that contains information regarding the top 500 people who can be promoted to top governmental positions. Similar reserves are being formed at the regional levels as well.

Although the cadres reserves are not unique in the sphere of public policy, the Russian reserve shares features more in line with those developed by transitional countries. Developers themselves outline that the "active use of the social institute of the reserve of professional cadres is pertinent predominantly for CIS countries, attempting transition to a democratic political regime and market economy...."24 In their comparative study, authors analyze personnel management systems in the developed countries (Germany, USA, France, UK, and Japan). In the selected countries, they could not detect similar institutions. At the same time, human resources technologies adopted in such post-Soviet countries as Ukraine and Kazakhstan have a lot of in common with the system built in Russia. This observation is also supported by some international experts. Thus, Eugene Huskey posits out that "[t]he cadres reserve lists differ from the job resume files maintained by American governmental organizations not just in their systematic identification and nomination of replacement personnel but in their professional development programs organized for individuals on the reserve lists. In this regard, they are closer to the succession lists maintained and nurtured by many large companies in the

${ }^{24}$ See: Analiz zarubezhnogo opyta formirovaniia rezerva upravlencheskikh kadrov gosudarstvennoi sluzhby. (2012). [Online]. (URL

http://rezerv.gov.ru/GovService.aspx?id=691\&t=34) . (Accessed May 28, 2013). 
West than the job application files that accumulate in American federal, state and local bureaucracies. ${ }^{25}$

Although the Russian cadres reserve itself does not follow the trends of personnel management that prevail in developed countries, it appears to be a very important feature of the reform of civil service. Under the second program of reform (2009-2013), further development of this institution constitutes the cornerstone feature of such aspects of reform as the "[i]ntroduction... of effective technologies and contemporary methods of personnel management. ${ }^{, 26}$ Unlike with some other aspects of the reform, most measures, aimed at establishment of the cadres reserves have been accomplished. Specialized lists of the most promising candidates for the executive positions within the administrative hierarchy were formed not only at the federal level, but also in most of the regions. In addition, necessary changes were introduced to the legal and regulatory frameworks, in order to improve procedural efficiency of personnel management based of this new institution.

It was assumed that introduction of the cadre reserve would allow the reformers to transform the methodology of educational, qualification improvement, and training programs, in order to make them more focused on the level of training and expertise of those who were enlisted in the reserve. These programs also were made more specific in terms of the expected skills and experience of persons, who were chosen to participate in the program. Finally, such specialization would improve cost-efficiency of budgetary

\footnotetext{
${ }^{25}$ Eugene Huskey (2003) Nomenklatura Lite? The Cadres Reserve in Russian Public Administration. Washington: NCEER., p.10.

${ }^{26}$ Decree of the President of the Russian Federation No.261 of March 10, 2009 "O federal'noi programme 'Reformirovanie i razvitie sistemy gosudarstvennoi sluzhby Rossiiskoi Federatsii (2009-2013 gody)'.’
} 
funds allocation. ${ }^{27}$ Official statistics provides evidence that this innovation has had moderate success. (Success here is understood in its straightforward connotation: e.g., whether the innovation has been in use). Both years, 2011 and 2012, approximately 20 percent of all advertised federal government jobs were filled by the employers from the cadres reserve lists; and in 2009-2011 46 percent of all appointments were made from the lists. ${ }^{28}$ Experts outline the growing interest in organization of the systems of cadre reserves at the regional level as well. For example, as one expert recounts elsewhere, in the Urals Federal District, quantity of appointments to regional governments almost doubled from 26 percent in 2007 to 48.8 percent in 2010 , and in some regions, namely "in 2010, in Tyumen oblast and the Yamal-Nenets Autonomous Okrug appointments for the vacant positions in the public service were made solely from the cadres reserve." ${ }^{29}$

The fact that the system of cadre reserves has been used rather intensively does not provide sufficient evidence that would allow one to conclude that the given approach is itself a positive factor that improves effectiveness of civil service as a whole. There is some evidence that the system, in the way it has been implemented, is susceptible to imbalances of various sorts.

${ }^{27}$ After introduction into practice of the cadre reserve system, there were made changes to the presidential program of training of public management personnel. Resolution of the Government No. 177 from March 24, 2007 "O podgotovke upravlencheskikh kadrov dlia organizatsii narodnogo khoziaistva Rossiiskoi Federatsii v 2007/08 - 2014/15 uchebnykh godakh" stated that the federal budget covers two thirds $(67 \%)$ of the total cost of education of a particular employer whereas another third $(33 \%)$ should be financed by the organization that sends its employer.

${ }^{28}$ See: Federal Portal of Administrative Cadres. (June 28, 2012). Analiz ispolzovaniia servisov Federal'nogo portala upravlencheskikh kadrov federal'nymi organami ispolnitel'noi vlasti v 2011 godu. [Online]. [URL http://rezerv.gov.ru/GovService.aspx?id=762\&t=34]. (Accessed: May 28, 2013).

${ }^{29}$ Semenov, V. (2010). "Za kachestvo upravlencheskikh kadrov." Gosudarstvennaia Sluzhba. No. 6. p. 11. 
Speaking of the latter, it is worthy to note the excessive diversification of the nomenclature in terms of reserved positions, closed qualification requirements and selection criteria, the disconnection of the processes of selection with that of educating and training/retraining the cadres, as well as an absence of a unique and universal system of government administration formulary for the formation of the cadre reserve. ${ }^{30}$ Inefficiency of the reserve is amplified by the inadequacy of processes of its organization, particularly with respect to its optimal size and the frequency, at which it is updated and the candidates are rotated. ${ }^{31}$

According to Arzhanukhin and Zerchaninova, such disparities have resulted in the emergence of "organizational pathologies that prevent effective management of the cadres reserve. ${ }^{, 32}$ They affect an achievement of one of the objectives of the reform of public service, namely the introduction of a modern and efficient system of management of the public service in the country. These pathologies became apparent in three key aspects of the functioning of the new model of public administration. Firstly, in terms of the organizational logic of reform in the country, there "was launched a new edition of

${ }^{30}$ Podbelskii N.V. (2010) Teoretiko-metodologicheskie osnovy postroeniia $i$ funktsionirovaniia regionalnykh sistem rezerva upravlencheskikh kadrov. Abstract of the Dissertation. Institute of Economy, Ural's division of the Russian Academy of Science. p.18 (Online) [URL: http://economy-lib.com/disser/38164/a?\#?page=1] (Accessed June $3,2013)$

${ }^{31}$ Semenov, V. (2010) "O povyshenii kachestva nauchno-metodicheskogo i informatsionno-analiticheskogo obespecheniia protsessa reformirovaniia i razvitiia gosudarstvennoi i munitsipal'noi sluzhby." Doklad. [Online] [URL: http://www.ucs-ms.ru/ed.php?id=47]. (Acessed 03.06.2013).

${ }^{32}$ Arzhanukhin S.V., Zerchaninova T.E. (2012) "Organizatsionnye patologii upravleniia kadrovym rezervom na gosudarstvennoi grazhdanskoi sluzhbe." Scientific Bulletin of the Ural Academy of Public Administration: politology, economics, sociology, law. No.

1(18). (Online) [URL http://vestnik.uapa.ru/ru-ru/issue/2012/01/13/] (Accessed June 2, 2013) 
the Soviet model of utilization of the reserve of nomenclature cadres." ${ }^{33}$ Secondly, the political aspect refers to the prevalence of vertical, predominantly top-down, connections in the hierarchy of the public service. Based on the power vertical, the system of patronage politics favours personal connections among the politicians and their subordinate public officials. Thus, political nominations, especially those at the regional level, greatly influence stability of the cadres of institutions of government as far as changes in the political elites are followed by substantial transformations in the upper layers of the bureaucratic corpus. Thirdly, the given system of cadre reserve is not capable of overcoming the trend of the deterioration of the professionalism of public officials. In some instances, the need to fill the reserve results in a dramatic drop in qualification demands. Taking into consideration these arguments, it may safely be argued that in processual terms, the created system of cadres reserve institution possesses many threats for successful fulfilment of other objectives of the reform.

The argument of potential hazards embedded into the system of cadres reserve is reinforced by an analysis of historical practices and theoretical premises of building similar systems. Eugene Huskey posits that "whether intended or not, the revival of cadres reserves has potentially disturbing consequences for the politics - administration nexus in Russia." ${ }^{34}$ In his opinion, the institution, should it be developed further, contradicts the nature of a merit-based public service, as it limits the pool of potential appointees. Moreover, the process of selection of appointees is rather subjective and may result in situations when candidates would be "selected for their weakness instead of their

33 Ibid.

${ }^{34}$ Eugene Huskey (2003). Nomenklatura Lite? The Cadres Reserve in Russian Public Administration. Washington: NCEER, p.12 
strength," 35 and would never question the position of their superiors. In this regard, the cadre reserve system does not help to improve the separation of political and administrative functions of governance as it was stated in the reform agenda. An inability to achieve this goal puts the entire reform (at least as it was) at risk. The absence of a clear demarcation line between political and administrative functions in the Soviet governance system, and an inability to overcome this Soviet heritage in the first postSoviet decade, was the major object of criticism among experts and politicians. Overcoming them was also stated as the fundamental objective of the current reform. Thus, institutionalizing the system as part of the reform could be considered inconsistent, if not contradictory. The resemblance of the cadres reserve to the Soviet system of recruitment and further recirculation of the cadres allows Huskey to name it "Nomenclatura-lite". However the new system could possibly be even more detrimental because "[i]n the Soviet system, the management of the reserve lists by an external institution, the Communist Party, counterbalanced this tendency toward self-protection, but there is no comparable mechanism in place in postcommunist Russia." 36

Potentially detrimental trends, as outlined in Huskey's observation, are reinforced by the fact that "personnel management policy is being conducted outside of public influence." 37 One of the factors that contributed to the existing situation is predominantly the ambivalent attitude of civil society to the reform of public administration and public service; the other factor being that the reformers, who themselves not only designed and conducted the reform out of public view, but also promoted measures that in principle

35 Ibid. p. 14

${ }^{36}$ Ibid. p. 13

${ }^{37}$ Oseichuk V. (2010) 'Kak preodolet' kadrovyi golod na grazhdanskoi i munitsipal'noi sluzhbe?" Gosudarstvennaia sluzhba. No.2. p.39. 
tend to neglect the role of public control over civil service. Furthermore, the cadres reserve is this exact measure.

Another, rather ambiguous 'innovation' of the reform of public service refers to the strengthening of social characteristics of public officials and an improvement of status of the entire bureaucratic stratum. The 2001 Conception of the reform stated that "social and juridical protection of a public official" is imperative for building an efficient and modern public service. In pursuit of this goal, there were made substantial addenda to the corresponding legislature. An additional article was included in two federal laws Federal Law No. 58-FZ, "On the system of state service of the Russian Federation", and later in Federal Law No. 79-FZ, "On the state civil service of the Russian Federation" that supplemented the already existing nomenclature of governmental positions with the so called 'civil service class rankings' (klassnye chiny). Introduction of class ranking has become another unique feature of the modernized Russian officialdom.

Class ranking as it is described in the normative documents vaguely reminds the holistic system of ranks introduced by the Emperor Peter I in 1721 and abolished 2 centuries later in 1917. Nowadays, under current conditions of the public service, class ranking was made 'legally essential' (i.e., it has become an integral part of the system). At the same time it is functionally redundant. It is targeted primarily not at the improvement of the quality of officialdom, but rather at the stimulation of corporatism as well as the improvement of the legal status of public officials. As it is stated in the document, "class ranks are given to federal public officials personally, consequently, in accordance with the taken post... as well as in accordance with professional 
qualifications, longevity of service in the previous class rank, and on the previous post." ${ }^{38}$ In total fifteen ranks were established. They were aggregated in 5 hierarchical groups: young (secretary), senior (referent), top-level (councilor), major (state-councilor), and the highest (actual state councilor), with each group including three ranks $\left(1^{\text {st }}, 2^{\text {nd }}\right.$, and $3^{\text {rd }}$ class). These class ranks substituted the 'qualification classes' of public officials that existed in the post-Soviet public service prior to the beginning of the latest reform.

Mounting together a rigid and intertwined hierarchy of governmental posts, bureaucratic ranks, and categories of public service jobs, contributes to social detachment of the bureaucracy from civil society and further development of closed corporatist ethics among public officials. In this case, the system of bureaucratic ranks does not possess any rational reason, but only the bureaucratic aesthetics. As Alexander Obolonskiy rightfully noticed in 1996, while discussing the reluctance of Yeltsin's reformers to dispose of this Soviet relic, in this regard the reformers "revive[d] the spirit of the $18^{\text {th }}$ century, and ha[d] outdone even Peter I in his passion for the barracks-type unification of everything." ${ }^{39}$ As officially stated, bureaucratic class ranks were introduced in order to improve the integrity of the system of state service. ${ }^{40}$ As was stated in the official documents, the new system should serve as a stimulus for an improvement of the quality and effectiveness of the state service. Public officials could progress through the hierarchy of class ranks by passing mandatory qualification exams and tests. Speaking of contemporary procedures

${ }^{38}$ Decree of the President of Russia No. 113 of February 1, 2005. "O poriadke prisvoeniia i sokhraneniia klassnykh chinov gosudarstvennoi grazhdanskoi sluzhby Rossiiskoi Federatsii federal'nym gosudarstvennym grazhdanskim sluzhashchim." ${ }^{39}$ Aleksander Obolonskii (1996) "Postsovetskoe chinovnichestvo: kvazibiurokraticheskii praviashchii klass." Obshhestvennye nauki i sovremennost. 1996. No. 5. p. 6. Decree of the President of the Russian Federation No. Pr-1496 from August 15, 2001 "Kontseptsiia reformirovaniia sistemy gosudarstvennoi sluzhby Rossiiskoi Federatsii". Article 3. 
of assignment of class ranks, Alexander Obolonskiy mentioned elsewhere that "the qualification exam nowadays is a (integral) part of the procedure of granting a consecutive class rank; and, [therefore], is almost unrelated to real testing of knowledge and competence of public officials." ${ }^{41}$ Instead, setting up a principle of consistency of sequence of granting class ranks in accordance with posts and longevity of service of public officials, brings rigidity and corporatist structure to the system of bureaucracy. A military-like promotion style of employers within civil service refers to a logic that emphasizes the spirit of subordination, and differs from the ethics of contemporary public administration. Tying class ranks to job posts also sufficiently reduces the potential for horizontal mobility of public officials, especially at the lower and middle levels. All this however, comes into contradiction with another normative dimension of the reform of public service and administration - building of a flexible, adjustable, and responsive bureaucratic apparatus.

\section{Conclusion}

As in the case of the reform of public administration, civil service reform can be considered partially successful. Reformers were able to establish new normative and legal framework of state (or public) service. They distinguished its three types: civil, military, and law-enforcement and provided different reform strategies for each type. Although such an approach was rather unusual and unique, it, in principle, allowed the reformers to more efficiently address the most vital aspects of each type of service that needed modernization. In case of civil service a modernization strategy was chosen that matched changes in the system of administrative institutions that occurred simultaneously with it.

\footnotetext{
${ }^{41}$ Alexander Obolonskii. (2009). Gosudarstvennaia sluzhba: kompleksnyi podkhod. Moscow: Delo. Chapter. 5
} 
For that matter, reformers utilized the same ideology of New Public Management that was used in case of public administration reform. The programmatic documents of the reform of civil service declared adherence to the major principles of accountability and ethics of public officials that were promoted by NPM. The flow of the reform process, however, begot quite interesting and, at the same time, influential ramifications from the mainstream New Public Management ideology of the government reforms. Two innovations - the systems of cadre reserves and class ranks - are the most cornerstone features of the modernized civil service that ultimately place in question applicability of managerial administrative techniques in the Russian case. The conceptual analysis of both innovations reveals that they promote corporatist integrity, as well as bottom-up accountability within the bureaucratic hierarchy.

Cadre reserves resemble the system of recruitment and promotion of public officials that existed during the Soviet period. Although it lost one major characteristic of the past era, namely communist ideology, it, nevertheless, resembled other features of vertical mobility that pertained to the Soviet nomenklatura model of bureaucracy. Altogether with the military style career promotion mechanisms through class ranks, the new system of Russian bureaucracy promotes a hierarchical model of accountability and suits well the logic of 'power vertical'. For the same reason, the reform was unsuccessful in improvement of horizontal interdepartmental links as well as reorientation of the professional ethos of Russian public officials to the interests of people and civil society. As a result of the reform a model of bureaucracy was established that contradicts expectations that were posited in the ideology of the reform. 


\section{Chapter VI. New Public Management measures in the Russian reform project: successes and failures}

\section{Introduction: New Public management in the context of the reform in}

\section{Russia}

Chapter VI culminates the analysis of the process of public administration reform in the Russian Federation. As the working hypothesis states, the major difficulties of reform implementation were rooted in the inconsistency in some of its planned measures, especially those that were based on the NPM theory of governance and those aspects of political process determined by strengthening the vertical of power. This chapter investigates in detail those aspects (or measures) of reform that were referred to in the reform as being driven by the ideology of New Public Management. In fact, all three measures that are mentioned in this chapter are considered NPM-based, because in comparison with other planned measures, performance management and budgeting, outsourcing, and competitive contractual state procurement administrative technologies provide public officials with some level of operational flexibility and administrative freedom for making decisions.

As it was shown in the previous chapter, ten years of reform efforts in the sphere of public administration produced rather misbalanced outcomes. Measures that were aimed at improving the structural characteristics of public administration, although with delays, were mainly achieved. These were measures related to the internal structure of the government and the bureaucratic apparatus. Reform actions that introduced principles of e-government may be considered partially successful. Again, as with the case of internal administrative processes, reformers were efficient in imposing a new infrastructure and 
demanding its implementation. At the federal, as well as regional levels, administrative bodies installed internet-based informational resources that contain important information about their activities. Reorientation of the reform from the improvement of government vis-à-vis business relations to the improvement of services provision for the general public had resulted in substantial systemic improvements and the creation of a unified internet portal for the provision of public services: http://www.gosuslugi.ru. At the same time, those measures that are regarded as related to the NPM paradigm, were not implemented as successfully and efficiently as the above mentioned measures.

Chapter 3 shows that although the plan of public administration reform was versatile and included various measures, the paradigm of New Public Management served as a sort of overarching metaphor for the entire reform. The program documents defined the primary objectives of the reform, namely the improvement of internal efficiency of the state apparatus and a reduction of its penetration into the economic sphere, in full concordance with the mainstream managerialist ideology of contemporary public administration. It included reform actions that may be related to the traditional, pro-bureaucratic measures. They were mainly aimed at restoring order and clarification of function of institutions and officials, as well as overcoming dysfunctional practices of governance, inherited from the Soviet period. These measures, although crucial, may be considered secondary. However, those measures that were aimed at a qualitative transformation of public administration in Russia were genuinely managerial in their fundamentals.

Failure to install and successfully launch these managerial measures raised an ultimate question about the entire reform project. As analysis shows, exactly these 
measures indicate the highest level of traction in implementation and resistance from the state apparatus. Systemic delays of implementation or, in some instances, the complete abandonment of reform actions posed a range of concerns regarding the reform in general. These procedural complications were complimented by a lack of overall improvement of performance of the state apparatus, indicated by the majority of governance indicators. Although the situation was rather predictable, due to the scope of modernization and the initial condition of the public apparatus, the ways in which the visible difficulties have been addressed raise a lot of questions.

Analysis of responses from politicians and officials in charge of the reform to emerging difficulties contributes to the explanation of its misfortunes. The reformers were successful in applying institutional changes. So, the new three-layer system of the federal government has never been under severe criticism. Its adoption, in formal terms, can be considered successful. Its dismantlement was not among the discussed options for fixing the reform. In many instances it formally satisfied both the reformers and the state apparatus. Reformers were more or less successful in the legal clarification of functional capacity of the government, invigilating the process of submission and approval of administrative regulations.

This chapter focuses on the most crucial managerial aspects of the reform. They are: performance management and budgeting, public and state procurement, as well as practices of outsourcing of governmental functions. All three measures can be presented as genuine derivatives of the New Public Management paradigm. Their successful implementation should substantially transform the nature of governance in Russia, moving the country closer to the mainstream standards of contemporary governance 
widely accepted by the majority of developed and developing countries. On the other hand, inability to introduce these changes would eliminate progress in other aspects of governance and jeopardize the accomplishment of the entire reform project in terms of achieving the proposed goals.

All three measures were unambiguously mentioned in the key documents of the reform. Cumulatively they attribute two symbolic features of NPM: improvement of performance of public officials on the basis of private sector management techniques and 'shrinking the state'. The latter concept implies a quantitative reduction of the public service by outsourcing supplementary functions, such as maintenance of governmental facilities and governmental procurement to private contractors, as well as the introduction of public-private or even private enterprises in the sphere of services provision. Thus, the state reduces not only its size, but also its spheres of governance.

Implementation of each of the three measures produced different outcomes. It may be stated that regardless of the fact that performance management and budgeting were introduced in the plan of reform almost in the beginning, little effort has been invested so far to install them at a substantial level. On the other hand, competitive state/public procurement in Russia has become an omnipresent practice, mostly due to the created legal framework and institutional capacity for its use. Although it was made mandatory, competitive procurement practices have produced controversial results and also cannot be regarded as an unambiguous success of the reform. Outsourcing, too, has been growing in the public sector. Its application, however, generated controversies that often were related to corruption and violation of fundamental principles of governance. Recent high-profile cases such as corruption scandals in the Ministry of Defense 
affiliated structures (Rosoboronexport and Rospromtorg), as well as in the Ministry of Agriculture (Rosagrolizing) revealed substantial defects in the proposed system. ${ }^{1}$

This situation is mimicked in the case of scientific assessment of these measures. Most observations and analyses have been dedicated to the problems of state procurement. Much less attention has been devoted to the difficulties in implementing performance management and budgeting initiatives. The latter topic is discussed predominantly from the normative standpoint due to a lack of empirical evidence. ${ }^{2}$ Particularly, although there has been a lot of raw data collected with respect to state procurement, the quantity of empirical studies is still insufficient. In this case, the problem of access to information and transparency of governmental activities must be specifically mentioned, as there are cornerstone impediments for successful implementation to the reform, or proper analysis of it for that matter. The very nature of New Public Management emphasizes accessibility of information on activities of public sector organizations.

Yet, regardless of the proposed measures as part of the federal program "Electronic Russia," the goal cannot be considered achieved. Estimates of the

\footnotetext{
${ }^{1}$ For more details regarding the cases refer to: Charles K. Bartles (2011) "Defense Reforms of Russian Defense Minister Anatolii Serdyukov." The Journal of Slavic Military Studies. Vol. 24, Issue 1., pp. 55-80.

${ }^{2}$ See: A.S. Kalgin (2012) "Upravlenie po rezul'tatam na regional'nom urovne: kontrol' ili rezul'tativnost'?" Voprosy gosudarstvennogo i munitsipalnogo upravleniia. No.3. p. 35-60.; and E.I. Dobroliubova (2008) "Vnedrenie printsipov i protsedur upravleniia po rezul'tatam v Rossiiskoi Federatsii: promezhutochnye itogi i napravleniia razvitiia" Voprosy gosudarstvennogo i munitsipal'nogo upravleniia. No.3, pp. 65-133.
} 
performance of public agencies using valid and objective criteria are still quite difficult due to the lack of information available for analysis. ${ }^{3}$

\section{Performance management and performance budgeting}

Of the three managerial measures of public administration reform in Russia to be discussed in this chapter, performance management - and closely linked with it, performance budgeting - are both the most unequivocal embodiment of the role and strength of contemporary NPM ideology. Although, performance as a concept within the disciplines of political science and public administration is not new, the way it was apprehended by the NPM approach is rather distinct.

Issues of performance and the efficiency of public agencies have always been at the core of the debates regarding governments and public policy. Over the years, different approaches to performance assessment-from simplistic economy driven costeffectiveness, to more sophisticated complex accountability models—were developed. Contemporary developments in the sphere are largely based on the idea of 'reinventing government.' The latter is no longer perceived as a "necessary evil," but rather a crucial factor in promoting sustainability of political, economic and social development. ${ }^{4}$ However, the role of the government has changed in accordance with the "steering, not rowing" political metaphor. ${ }^{5}$

\footnotetext{
${ }^{3}$ The problem has been mentioned by several experts. See for example: Andrei Yakovlev, (2012). "Sistema goszakupok v Rossii: na poroge tret'ei reform." Obshchestvennye nauki i sovremennost' [Social Sciences and the Modernity], No.5, p. 63.

${ }^{4}$ Robert B. Denhardt; Janet Vinzant Denhardt (2000) “The New Public Service: Serving Rather than Steering." Public Administration Review. Vol. 60, No. 6, pp. 549-559.

${ }^{5}$ David Osborne, Ted Gaebler (1993) Reinventing Government: How the Entrepreneurial Spirit is Transforming the Public Sector. New York: Penguin Books.
} 
The science of public administration developed a rather complicated, but also quite holistic, typology of approaches to managing the performance of public agencies. Complications begin at the early stage of defining performance, which appears to be a non-unitary concept. ${ }^{6}$ Bouckaert and Halligan suggest that "[t]here is a span of performance and a depth of performance." 7 These two characteristics define the ontological boundaries of the discourse on performance. The former is explained as the horizontal dimension - basic input/output framework that explains the need to organize public sector performance measurement systems "at the level of a policy field", surpassing the simplistic "individual organisational level." ${ }^{8}$ Depth of performance is a vertical dimension that has three levels: micro (representing performance of individual organizations), meso (referring to efficiency of specific policies), and macro (or the entire government's performance) levels. This ontological framework allows delineating the four categories of performance in public administration discourse that "denote successively greater degrees of complexity and integration," namely Performance Administration, Managements of Performances, Performance Management, and Performance Governance. ${ }^{9}$

Bouckaert and Halligan's ontological approach establishes the boundaries of the contemporary understanding of performance in the governmental sector. Another, more empirically driven taxonomy provides "three very distinct foci in terms of what is supposed to be for 'performing' in current theory and practice...: organizational

\footnotetext{
${ }^{6}$ Tony Bovaird (1996). "Developing new forms of partnership with the 'market' in the procurement of public services." Public Administration Vol. 84, No. 1, p. 147 ${ }^{7}$ Geert Bouckaert and John Halligan (2008). Managing Performance: International Comparisons. London: Routlege., p. 15

${ }^{8}$ Ibid., p.16

${ }^{9}$ Ibid., p.4
} 
performance; performance of policies or programs...; and performance by public servants. ${ }^{10}$ Each aspect of performance is vocal in the contemporary context; each allows one to focus on the outcomes, as the major point of interest form political decision-making. Organizational performance is most often addressed in the respective scholarly literature and practical policy initiatives. It also resembles performance administration in Bouckaert and Halligan's ontologically driven taxonomy.

Reforms of public administration worldwide first and foremost tend to improve performance of public agencies. The most common contemporary approach in discussion of organizational performance is that of efficiency of budgetary funds allocation. The contemporary approach to performance has shifted from the procedure-based and inputoriented model to a model of performance focused predominantly (and in the most extreme cases, exclusively) on outcomes. The understanding of organizational efficiency within the traditional approach to governance focuses on proper allocation of budgetary resources. In other words, the theory suggests that public institutions are designed to perform particular goals; and in order to fulfil these goals these institutions are assigned portions of budgetary funds. At the same time, accountability and, thus, efficiency, are embedded into proper administrative procedures. This approach involves a form of budgeting based on the cost estimation principle. Organizations are funded on the basis of their estimated spending needed to perform their duties. Evaluation of organizational performance within such a model is rather limited, as public officials are not responsible for efficiency of the policies they are 'given' for implementation. They only could be

\footnotetext{
${ }^{10}$ Colin Talbot (2005). "Performance Management." in Ewan Ferlie, Laurence E. Lynn, Jr. and Christopher Pollitt (eds.). The Oxford Handbook of Public Management. Oxford, UK: Oxford University Press., p. 494.
} 
assessed on the basis of procedural accuracy of policy implementation. This model resembles the classical bureaucratic approach once classified by Weber and von Mieses, and described as irresponsive and "sluggish" over the subsequent years of its implementation.

The model was largely stigmatized in some countries during the anti-bureaucratic, 'shrinking government', revolution of late 1970s - early 1980s. Yet it was never completely abandoned, nor substituted. At the same time critical rethinking was put at the core of the 'reinventing government movement' that was generally driven by an idea of the introduction of private sector principles of management into governance practices.

This managerial revolution argued for the need for more operational freedom for public officials in allocating budgetary resources, as it would provide them with better capacity to accomplish jobs they are entitled to. This approach capitalized on both, the Weberian idea of professional competence of public officials and the idea of assessment of activity outcomes, derived from the private sector. It was hypothesized that the public official, due to their almost exclusive power of expertise, should be given freedom of selection of ways to manage assigned resources in order to improve performance of their agencies.

The most extreme connotation suggested the establishment of a business-like model of governance and treating citizens as customers. In this case, efficiency and performance of public agencies would resemble the market approach. Such an approach, however, was immediately criticized, especially by academics, with two arguments dominating. First of all, underperformance of public agencies most likely would not result in their bankruptcy, as might happen in case of private enterprises. Secondly, many 
types of public functions are not compatible with the private sector value-adding approach. Such public functions as, for example, national security, cannot be attributed to commercialization. Yet, the need to assess performance of agencies that execute such functions was considered important. In addition, comparing public and private values, ethical questions of accountability were raised. Although the radical entrepreneurial approach was almost unanimously rejected, some of the private sector mechanisms of performance improvement that prove to be efficient were taken into consideration.

Over years of discussions, the theoretical milieu established several distinct approaches to accountability within the New Public Management Paradigm. ${ }^{11}$ The first approach linked public accountability to transparency. It suggested that the shift of focus from inputs to outputs in the democratic system must go hand in hand with greater transparency of the achieved results. This approach argued for focusing on audit and performance reports as the major management feature.

The second approach was based upon the ideal of the assurance of quality standards. Functions of public sector organizations, as well as services they provide, should be standardized. "[P]ublic organizations should make clear statements about the levels of service they intend to supply, in terms of timeliness, accessibility and quality, and then report on their success against these aims."12 These decisions should be made at the political level and involve democratic procedures in order to assure the validity of the created standards. Such an approach possesses great value in the case of provision of uncompetitive public services, especially in cases where state institutions have exclusive rights for services provision.

${ }^{11}$ Colin Talbot (2005) Op.cit., p.496
${ }^{12}$ Colin Talbot (2005) Op.cit., p.497 
The third approach referred to the internal monitoring of the activities of public agents. It was based on the principal-agent theory and reinforced the idea of proper monitoring of results. Unlike the first approach, the major objective of which was the assurance of public institutions' accountability, this one is genuinely managerial and refers to methods of improving work in both quality and quantity.

Therefore, in addressing performance, the new public management approach establishes three crucial dimensions that are capable of simultaneous empirical implementation. The first one focuses on the outcomes of public agencies and/or efficiency of the implementation of various governmental programs and policies. This approach includes both cost-efficiency analysis and the provision of managerial freedom for the proper allocation of public resources. The second dimension emphasizes the audit of procedural coherence, as often public agencies reserve monopoly status for the provision of some types of public services, as well as implementation of some functions. In this case, performance is being assessed against clear and preferably quantitative indicators. The final, third dimension refers to the genuinely public aspect that cannot be ignored within the modern welfare state paradigm. It states that by means of their activities, public agencies not only satisfy customers and compete for scarce public resources, but also create public value. ${ }^{13}$ The argument refers to the incommensurability of public and private sectors that have ontologically different objectives. ${ }^{14}$ In this case,

${ }^{13}$ Ibid., p.501

${ }^{14}$ For the discussion see: George A. Boyne (2002) "Public and Private Management: What's the Difference?” Journal of Management Studies. Vol.39, Issue 1, pp. 97-122; and Yuri Kuznetsov (2004). "Nekommercheskoe gosudarstvo" Otechestvennye zapiski. No. 2 (17). 
performance is not solely linked to cost-effectiveness, but envisages a larger debate on the role of government in the contemporary world.

Nevertheless, being closely linked with efficiency, performance management creates a rather peculiar perspective on budgeting. In a very simple and straightforward connotation, the ultimate goal of public agencies is to reduce costs of their work as much as possible. At the same time this approach creates a dilemma that, in particular, became the cornerstone feature of the implementation of performance management and budgeting techniques in Russia. The dilemma states that more efficient public organizations that spend lesser portion of their budgetary funding may find themselves in the position of having their budgetary allocations substantially reduced. Therefore, traditionally designed budget codes do not provide incentives for officials to optimize their spending. This would probably be one of the most fundamental issues with new public management, especially in those spheres of administration, where profit maximization logic is not applicable. The solution for this problem, which simultaneously takes performance and efficiency concepts into account, would be, as suggested by Bouckaert and Halligan, in moving towards more holistic, governance performance management technologies. However, as they said: "It appears that the main focus of NPM was single organisational and neither meta, extra organisational, nor horizontal. ${ }^{, 15}$

Theoretical deliberations on performance management and budgeting were well accompanied by instances of practical implementation of management solutions developed either in academia, or adopted from the business sphere. Those countries that advanced in the adoption of new principles of governance created various political

\footnotetext{
${ }^{15}$ Geert Bouckaert and John Halligan (2008). Managing Performance: International Comparisons. London: Routlege., p.59
} 
programs for improving performance and accountability of public institutions, many of which acquired appellative meaning.

For example, in the United States, performance was understood as an aggregate of two factors: more operational freedom of public officials, on the one hand; and more oversight of their activities by Congress, on the other. The tradition of measuring performance of US governmental agencies dates back to the 1912 Taft Commission. "Rising government spending, and debt associated with financing World War I, led Congress to pursue a budget system that would also act as a tool for controlling federal spending." ${ }^{.16}$ One of its recent incarnations was the Budget and Performance Integration Initiative (or BPI). ${ }^{17}$ The program was based on a several-decade-long initiative of political authorities to ensure that public agencies are both efficient in allocating public funds and serve to the best interest of the country.

BPI's major focus is on better utilization of scarce budgetary funds. The idea behind the initiative was to develop a reliable yet representative methodology that would help to evaluate quantitative as well as qualitative parameters of performance of public agencies. A huge impulse to search for adequate performance management tools was a result of the National Performance Review initiative, proposed by the President Clinton's administration. The efforts resulted in The Government Performance and Results Act

\footnotetext{
${ }^{16}$ F. Stevens Redburn et.al. (2007) Performance-Based Management: How Governments Can Learn from Experience in F. Stevens Redburn et.al. (eds). Performance Management and Budgeting: How Governments Can Learn from Experience. M.E.Sharpe: Armonk, NY., p.7

${ }^{17}$ Robert J. Shea (2008) "Performance Budgeting in the United States." OECD Journal on Budgeting. Vol.8 No. 1.
} 
(GPRA) that required "federal agencies to identify both annual and long-term goals, to collect and report performance data, and to implement strategies to improve."18

The comprehensive approach provided by the GPRA would allow the efficient reallocation of public funding to those aspects of governance that need greater attention. It would also allow the government to promote, introduce changes, or even cancel inefficient governmental initiatives. Clinton's administration initiatives were put in the core of the BPI, yet the focus shifted from planning to budgeting. Two distinct features appeared in the core of this initiative: the Program Assessment Rating Tool (PART) and the Balanced Scorecard methodology.

"PART is designed to build upon performance information developed by agencies in response to GPRA." ${ }^{19}$ It contains several easily quantifiable parameters that, when combined, allow the evaluation of the efficiency of a policy or an agency on a five-point scale from effective, as the highest possible rank, to results not demonstrated, as the lowest one. In addition to PART the Balanced Scorecard methodology has become the prominent tool for assessment of management performance in the United States. As stated elsewhere "[b]y combining financial measures and non-financial measures in a single report, the Balanced Scorecard aims to provide managers with richer and more relevant information about activities they are managing than is provided by financial

\footnotetext{
${ }^{18}$ F. Stevens Redburn et.al (2007). Op.cit., p. 10

19 John B. Gilmour (2007). “Implementing OMB's Program Assessment Rating Tool: Meeting the Challenges of Performance-Based Budgeting" in F. Stevens Redburn et.al. (eds). Performance Management and Budgeting: How Governments Can Learn from Experience. M.E.Sharpe: Armonk, NY., p.21
} 
measures alone. ${ }^{20}$ Initially developed for the private sector, the tool has become very popular in the public sector.

In the United Kingdom the more holistic Next Steps Initiative created a specific vision of performance. At the epicenter of the program lay the separation of political (or strategic control) and administrative (or day-to-day management) functions. ${ }^{21}$ This allowed the reformers to create semi-autonomous public agencies that gained significant amount of operational freedom, as it was considered the prerequisite for efficient allocation of budgetary funds. In order to ensure control and accountability over the new deregulated system "[e]ach agency is required to produce a corporate plan, typically covering a three- to five-year period, with annual business plans being developed from this base. Performance targets, financial projections, assessment of prospects and other information are included in the plans." 22

Examples of performance management techniques that were formed under the aegis of New Public Management allow us to summarize their few major characteristics. Firstly, they were all institutionalized. Each proposed measure was made into a distinct governmental policy (NPR, GPRA, BPI in the United States, The Next Steps in the United Kingdom, and similarly the Public Service Reform Act in Australia). This showed

\footnotetext{
${ }^{20}$ Ian Cobbold and Gavin Lawrie (2002) "The development of the Balanced Scorecard as a strategic management tool." Paper presented at PMA Conference, Boston, USA, May 2002. (Online) [URL: http://memberfiles.freewebs.com/84/90/65819084/documents/Balace\%20Score\%20card1.PDF] (accessed September 13, 2013).

${ }^{21}$ The Next Steps Initiative (1989) London: HMSO Publications Centre. (Online) [URL: http://www.official-documents.gov.uk/document/hc8889/hc04/0410/0410.pdf ] (Accessed: September 14, 2013).

${ }^{22}$ Ron Eden and Noel Hyndman. (1999) "Performance measurement in the UK public sector: Poisoned chalice or Holy Grail?" Optimum, The Journal of Public Sector Management. Vol. 29, No. 1., p.13
} 
governments' commitment to these reforms and their unwillingness to hide them behind complex and obscure sets of legislation. Secondly, the reforms emphasized operational freedom for public officials in order to achieve efficiency improvements. Thirdly, strategic planning was made a very important feature of a successful model of performance management, as it balanced operational freedom. In this instance administrative aspects of optimality and efficiency are weighed against the strategic vision of a government's goals in at least mid-term perspective. "Effective programs set clear performance objectives, develop realistic strategies for achieving those objectives, and continually review their progress to improve their performance. This requires an ongoing annual planning and review cycle integrated with the agency's budgeting cycle and with agency-level strategic planning processes., 23

Putting NPM at the core of the reform ideology, Russian reformers could not omit a discussion of performance in managerial terms. In fact, the performance management aspect of the reform had been mentioned among the top priorities of the Russian public administration reform from the very beginning. Describing all six major aspects in the 2006-2008 Conception of Administrative Reform in Russia, ${ }^{24}$ the authors actually put performance management in front of all the other measures. ${ }^{25}$ They understood performance management as a system of coordinated administrative actions aimed at strategic planning, control of execution, and corrections if necessary—organized around a

\footnotetext{
${ }^{23}$ F. Stevens Redburn et.al. (2007) Op.cit., p.7

${ }^{24}$ Resolution of the Government of the Russian Federation No. 1789-r, from October 25, 2005. "Kontseptsiia administrativnoi reformy v Rossiiskoi Federatsii v 2006 - 2008 godakh"

${ }^{25}$ The Second edition of the Conception of Administrative reform that extended the second phase of the reform until 2010 included two extra aspects, yet it did not show change in the attitude of the reformers, regarding importance of implementation of performance management.
} 
result-based mindset. This mindset and understanding is evident from the constricted guidelines and methodology of this aspect's implementation that the reformers created.

The methodology of implementation of performance management was planned and developed into several mechanisms with which to achieve this change. Firstly, reformers planned to create a complex system of inter-institutional project planning and resource management. Secondly, they planned to develop key effectiveness and result assessment indicators. The third planned mechanism was organized around a creation of a procedure of goal setting, as well as the distribution of these goals to executors and a development of indicators for the assessment of the achievability or attainment of these goals. The fourth included a creation of a control and monitoring system which would allow for both effective distribution of resources to each set objectives, and also accountability over the results and the responsible managers. The fifth included a creation and implementation of a system of internal audit, with the sixth, the development of a system of risk assessment. Finally, they also planned to create a mechanism of control of subordinate agencies within the system.

These seven mechanisms, which were meant to be result-based, were meant to create a normative and legal methodological framework, which would allow experimental testing and implementation of performance management. Thus strategic planning and project control were seen as key for the successful implementation of this reform. Furthermore, the system of results based control was planned in coordination with other reforms, such as the Concept of the reform of the budgetary process of the Russian Federation in 2004-2006, and the Federal program of Electronic Russia (2002- 
2010). ${ }^{26}$ Given the necessity of coordinating performance management reform with these two other reforms, the authors outlined several tasks that must be introduced in the course of the reform. These tasks are:

- Formation of a system of performance indicators;

- An improvement of a methodology of and order of developing an intermediate program of goals;

- Development and implementation of a methodology of estimating resource provision for the planned goals and problems being addressed;

- Creation of a mechanism for the distribution of resources to competing institutes, with specific methods on how to choose between two or more competing methods of utilizing budgetary resources to fulfill the needed functions;

- The implementation of a control and monitoring system over the spending of budgetary resources;

- The implementation of a system of internal audit to verify the effective use of budgetary resources;

- Creation of a whole government information system of planning and monitoring the effectiveness of government activities;

- Formation of a system to properly stimulate government workers.

These tasks were meant to be realized firstly by ministries, and secondly by the subsequent subordinate organizations. They key consideration is the substantial use of

\footnotetext{
${ }^{26}$ Resolution of the Government of the Russian Federation No. 249 of May 22, 2004 " O merakh po povysheniiu rezul'tativnosti biudgetnykh raskhodov".
} 
both direct control and the presence of a methodological framework on how to achieve the performance management aspect of the reform - a high level of micromanagement.

Overall, assessing the Russian approach to performance management, it may be stated that the proposed measures in the 2005 Conception, fully match the concern once raised elsewhere regarding the inability of some governments to reshape their vision of public agencies. It is stated that "[p]olitical discourse has still tended to focus on 'getting and spending' — tax and budgets—rather than 'achieving'.,27

The plan of reform included a series of measures that should be performed in 2006-2008. Of all the mechanisms and instruments available, Russian reformers decided to focus on and promote strategic planning. Other aspects of the implementation of performance management that were addressed in the theoretical discourses or empirical cases were not presented in the Russian reform agenda. Provision of operational freedom - an aspect that was addressed in both internationally recognizable reforms in the UK and the US-was not mentioned, neither in the 2005 Conception of the reform, nor in any other key documents.

Almost all measures mentioned in the 2005 Conception that were aimed at the instalment of performance management were related, in one way or another, to the development of planning mechanisms. The strategic planning initiative was well apprehended in the context of the reform in Russia. Since 2007, the Ministry of Finance has been preparing three year budget plans that substituted previous one-year budgets. In addition, long-term programs of the country's development are produced. In theory, these

${ }^{27}$ Colin Talbot (2001). "Performance Management." In Ewan Ferlie, Laurence E. Lynn, Jr. and Christopher Pollitt (eds.) The Oxford Handbook of Public Management, Chapter 21.,p. 492 
documents should establish the vision of Russian development, measure existing resources and form administrative capacity for their efficient allocation in the most strategically significant sectors of the national economy, as well as social and political spheres. As a result of these activities, since 2008, all public institutions of the state at the federal level, as well in the regions, have become obliged to prepare special reports on the results and major directions of future activities (the so-called DRONDs). The DRONDs are related to the relatively new initiative of the government to provide midterm, three-year budgetary plans.

These reports, in principle, resemble the structure of reports that public agencies prepare in countries that have succeeded in adopting performance management techniques. The structure is firm and includes five major clusters of information: 1) goals and tasks of the agency; 2) sources of income and spheres of expenditure; 3) results of activities (in the previous period); 4) allocation of spending in accordance with goals, tasks, and assigned programs; 5) review of efficiency of budgetary spending. The reports are prepared in accordance with methodical recommendations, prepared by the Ministry of Finance and submitted for approval to the Government of Russia or respective region and the Ministry of Finance. Since 2008, each governmental institution has been preparing such rather weighty reports. All of them are also posted on the websites of the respective public institutions.

The federal government also prepares and submits similar documents, which however target a longer (up to five years) perspective. In addition to such documents, federal political authorities are involved in larger strategic plans of development of the country that to a greater extent resemble the logic of strategic planning developed for 
performance management. These documents may be seen as meso- and macro-level dimensions of performance management respectively, if we are to use the Bouckaert's discourse.

The macro-level conception would be the Conception of a long-term social and economic development of Russia until 2020, most commonly known as Strategy $2020 .{ }^{28}$ It established major goals and parameters of development of the country in the period until 2020. The Conception was prepared in 2011. It included the same five clusters and focused on similar parameters of socio-economic development of the country. Although the Strategy - 2020 was prepared with the participation of the leading academics, it was criticized for its isolation from socio-economic realities. ${ }^{29}$ The fact that the issued in 2011 the Strategy - 2020 was actually the second attempt at such strategic forecasting and planning, implicitly supports concerns raised by sceptics. The first attempt was undertaken in 2007 and proved to be unrealistic.

In order to assess the impact of performance management techniques on activities of public organizations, experts of the Higher School of Economics conducted a survey of rank-and-file regional officials. ${ }^{30}$ In general, the analysis revealed that the current approach to performance management, as it was described by the 2005 Conception of administrative reform, did not help in improving the efficiency of public agencies and

\footnotetext{
${ }^{28}$ For more details see: The final report on the results of expert research on the topical problems of social and economic development of Russia until 2020 "Strategiia-2020: Novaia model' rosta - novaia sotsial'naia politika." (Online). [URL: http://2020strategy.ru/data/2012/03/14/1214585998/1itog.pdf] (Accessed: October 22, 2013).

${ }^{29}$ See for example: Alexander Ivanter et al. (August 29, 2011) "Ne khvataet klassa". Expert, No.34(767).

${ }^{30}$ Alexander Kalgin (2012) “Upravleniie po rezul'tatam na regional'nom urovne." Voprosy gosudarstvennogo i munitsipal'nogo upravleniia. No.3, pp. 35-60.
} 
approximated them to the standards of efficiency and public accountability recorded in the countries where performance initiatives originated. Moreover, it may even be stated that it has not resulted in any substantial change whatsoever.

The survey revealed that, although designed to improve administrative efficiency, the practice of preparation of reports (DRONDs) serves the rather opposite goal of vertical administrative control. In addition, the managerial effect of the innovation was estimated as insignificant. Deeper investigation into the problem revealed several other problems that stressed insufficiency of the proposed measures. First of all, the research approved the conceptual critique that the entire process of planning is badly administered, as far as receiving feedback has not been ensured.

Secondly, the established system of performance management does not promote horizontal, intradepartmental cooperation and coordination. The established system of hierarchical accountability, altogether with insufficient top-down control over activity of public officials, does not enhance interests of public officials in improving quality of their work, which involves horizontal, interdepartmental cooperation. This is especially topical for the issues of services provision and creates excessive traction for another reformatory initiative, namely the establishment of multi-functional centres. Adoption of federal law No.210-FZ "On organization of provision of state and municipal services" established a regulation that prohibited civil servants from demanding that applicants provide those documents that can be ordered by public officials themselves. This created a legal infrastructure that should foster managerial governance practices. Yet the established, as a result of the reform, the administrative processes that were established as a result of the reform, do not conceptually match the proposed infrastructure. The key to the problem 
lies in the process of reporting on the results of activities, when the indicators of efficiency are coordinated at the very top of the administrative ladder; therefore the apparatus of the government appears to be ultimately responsible for the verification and approval of performance indicators. In reality the process is characterized as "hanging up" or "pushing aside" of indicators. ${ }^{31}$ In addition, the latter can be assigned unevenly; and this creates additional reluctance for public agents to cooperate.

Finally, and perhaps more importantly, respondents argued that public agencies are deprived of the ability to have an effect upon the indicators of performance established for them. Quite often performance or underperformance of an agency is influenced by external factors. In this case quantitative indicators often fail to provide reliable information. For example, at the federal level, ability to utilize more resources during times of economic prosperity does not indicate an improvement of efficiency. Similar logic is valid for outcome indicators. At the regional level, performance indicators often indicate efforts made at the federal level. This argument seems to be even more applicable, taking into account the recent developments in the sphere of federal relations in Russia.

Critical assessments of the typical performance indicators, developed specifically for the report, also suggest that the proposed system of strategic planning does not support an improvement of efficiency of public agencies. Of all created eight indicators only one - education efforts - showed its moderate usefulness. The usefulness of all others, including: evaluations, control, budgeting efficiency, motivation, promotion of an institution, remuneration, and improvement - was low.

${ }^{31}$ Ibid, p.48 
Most of performance management initiatives that were discussed in the previous pages, relate to the lower and middle levels of the bureaucratic hierarchy. It is quite obvious that they were mainly unsuccessful. However, apart from them, there was a political attempt to influence performance at the executive level. This attempt affected predominantly the gubernatorial corpus. In 2007, President Putin introduced 43 criteria of efficiency of regional leaders. Until November 2012 this quantity was increasing continuously and reached the mark of more than 300. In November president Putin reduced the number of criteria to 12 . Only the most recent initiatives of the government in developing these gubernatorial ratings involved monetary incentives for the regions. As Minister for Open Government Mikhail Abyzov stated in September 2013, the most successful regions would receive 20 bln rubles (approximately US \$ 650 million) of grants from the federal budget. Previous ratings, apart from being too cumbersome, served the sole purpose of control, not encouragement.

The example of practices of performance-based management in Russia evidently reveals the conflict between the two dominant concepts of the reform: managerial ideology and the top-down accountability of public officials within the power vertical paradigm. Implementation of performance measures that predominantly were narrowed to strategic planning does not provide sufficient incentives (including monetary ones) for public officials to improve their performance. Yet, the system of vertical accountability emphasizes compliance with regulations and orders over performance improvement. In such circumstances strategic planning initiatives appear to be superficial and demonstrate the managerial façade of the entirely bureaucratized governance machine in Russia. As 
one public official mentioned "since we are not forced to prepare the DROND, so we have given up on it." 32

\section{State and Public Procurement}

Of the three aspects of Russian public administration reform that are being discussed in this chapter, state and public procurement (hereafter state procurement) appears to be the most conceptually developed and thoroughly implemented, as well as substantially captured in the academic literature.

The given dissertation discusses state procurement among the NPM-inspired aspects of the public administration reform. The reform's primary objective was the improvement of procurement procedures in order to enhance the efficiency of public spending and the optimization of the work of public organizations. In this regard, public officials were given some degree of discretion in how they would allocate budgetary funds in order to achieve the proposed goals; at the same time, legislation provided a thorough legal framework for conducting this form of administrative activity. It was expected that the reform would result in substantial improvements in procurement strategy of public institutions. This, in turn, would improve efficiency of utilization of public resources and, perhaps, overall performance of public administration.

It is also important to mention that in the Russian case, optimization and improvement of efficiency of public agencies should not immediately be related with a reduction in spending on procurement, especially when the first years of reform are being analyzed. The idea of nominal reduction of public expenditures dominates the discourse,

\footnotetext{
${ }^{32}$ Alexander Kalgin (2012). “Upravlenie po rezul'tatam na regional'nom urovne: kontrol' ili rezul'tativnost'?" Voprosy gosudarstvennogo i munitsipalnogo upravleniia. No.3, p. 50
} 
and it is expected that the proper procurement reform would result in substantial cuts of budgetary spending on supplying a public administration with various goods and services. In the Russian case however, it must be expected that initial budgetary spending on procurement may increase. There are several factors that determine this circumstance. Initially, Russia had to make substantial adjustments to the nature of state procurement. These changes were determined by the need for government to shift from Soviet type procurement, based on the planned economy, to the market-based principles of supplying public organizations. During this transition the old supply network was shattered and due to bad performance of the national economy in the 1990s, new ties between government agencies and their suppliers were not developed. This resulted in a deterioration of qualitative and quantitative characteristics of public administration's activities. This, in particular became one of the factors that determined the need for the reform of governance in Russia. ${ }^{33}$ Adjustments to the system of state procurement during the 1990s were made incrementally, enforcing the existence of shadow schemes and corruption in this sphere.

Therefore, the reform was not limited to the above-mentioned issues of transparency and corruption. It took a larger outlook on the problem, and posited that there must be created "a system of justification of [public] expenses on procurement of goods (labour, services) for public needs, in order to be able to forecast and plan in advance the related expenses of the federal budget. ${ }^{34}$ At the same time, the ultimate goal

\footnotetext{
${ }^{33}$ Deterioration of quality of public service in Russia discussed in detail in Chapter 2 of the given dissertation.

${ }^{34}$ Resolution of the Government of the Russian Federation of October 25, 2005. No. 1789-r "Kontseptsiia administrativnoi reformy v Rossiiskoi Federatsii v 2006 - 2008 godakh"
} 
of the modernization project was the stated substantial improvement of the quality of public service as a result of the establishment of the above-mentioned system of proper state procurement.

Stated this way, the objectives of the reform create an interesting analytical dilemma for researchers. Obviously, the statement invalidated simple and straightforward quantitative methods of assessing efficiency of the proposed reformatory efforts. As far as public administration demanded substantial investments into its infrastructure, it has become impossible to simply compare pre- and post-reform budgetary spending on procurement in order to figure out whether the changes have led to positive or negative outcomes. Instead, more complex indicators are needed in order to establish the relationship between public spending and improvement of administrative efficiency. This research dilemma has forced scholars to focus on the second aspect of the reform, namely on improvement and efficiency of the regulations in the given sphere, as well as on issues of corruption and the transparency of procedures of state and public procurement. ${ }^{35}$

State procurement reform in Russia attracted wide academic attention domestically, as well as internationally. Substantial contributions were made, both empirical (quantitative) and theoretical, on the nature of the reform processes. The most common estimate that has been given to the reform so far is that the reform has not yet

${ }^{35}$ See for example: Andrei Yakovlev, Olga Demidova (2012). "Access of firms to public procurement in Russia in the 2000s: before and after radical reform of regulation." International Journal of Economic Policy in Emerging Economies, Vol. 5, No. 2. 
achieved its goals and "the Russian Federation remains a high-procurement-risk country.",36

Issues of public procurement were given special attention within the reform of public administration. The Conception of Administrative Reform in 2006-2008 (2005 Conception) provided scrupulous analysis of the current conditions of state and public procurement, stating that the "actual system of procurement remains insufficiently effective" ${ }^{37}$ and proposed a set of measures in order to improve the situation in this sphere.

Attempts to reform the system of state procurement are traced back to the 1990 s. They were urged by the need to adjust Russian public administration to the new principles of the market economy. The Soviet system of planned economy and centralized directive procurement of the state apparatus was vested on solid ties between state-controlled corporations and the state administration. Governmental organizations were supplied with necessary goods through the system of Gossnab ${ }^{38}$ in accordance with the Five-Year Plans for the National Economy. Dissolution of the Soviet Union and the liberal economic reforms in Russia in 1991-1992 interrupted these connections. In order to introduce some intermediary regulations in this sphere, in 1992, President Yeltsin issued decree No.826 "On the measures of establishment of the Federal Contractual

\footnotetext{
${ }^{36}$ World Bank (2006) Russian Federation - Country Procurement Assessment Report. Operational Policy and Services, December, Europe and Central Asia Region, The World Bank, Washington DC., p.11

${ }^{37}$ Resolution of the Government of the Russian Federation of October 25, 2005. No. 1789-r "Kontseptsiia administrativnoi reformy v Rossiiskoi Federatsii v 2006 - 2008 godakh."

${ }^{38}$ Gossnab is the public term for the State Committee of the Union of Soviet Socialist Republics for material and technical procurement. This state committee was introduced in 1948 and existed until dissolution of the Soviet Union in 1991 with 12-year intermission (between 1953 and 1965).
} 
System," where it was stated that "the [s]tate procurement is being performed in accordance with market prices (excluding goods, which prices are still being regulated by the state) and on the bases of state contracts with producers of goods and services, or intermediary organizations and in accordance with existing budgetary resources." 39 Therefore, in some cases, the state was able to secure the continuation of procurement due to participation in capital of some economic enterprises and controlling price formation. In some other cases it had become the responsibility of the personnel of public agencies to find suppliers using market mechanisms of bargaining and competition. Procurement had become an ill-regulated activity that was plagued by lack of trust between suppliers (private enterprises) and consumers (public agencies) on the one hand, and an arduous economic situation that was marked by a budget deficit, substantial undersupply of the public sector and, in some instances, insolvency of public organizations.

The need for uniformity and substantial regulation of the sphere of state procurement was obvious. As with many other modernization projects that were undertaken by Boris Yeltsin's administration, the reform of state procurement was based on a model created by an international organization. In this particular case, the legislation was adapted from the model law that was developed and proposed by the United Nations Commission on International Trade Law (UNCITRAL). The 1994 edition of the documents was put in the core of the 1997 presidential decree No.305 "On the immediate measures for prevention of corruption and reduction of budgetary spending on

\footnotetext{
${ }^{39}$ Decree of the President of the Russian Federation No.826 from August 7, 1992 "O merakh po formirovaniiu Federal'noi kontraktnoi sistemy", Article 1.
} 
procurement of goods for public needs. ${ }^{40}$ Following international practice, the decree established several important regulations to the process. First of all, it declared mandatory the competitive nature of state procurement. Non-competitive acquisition of goods and services was strictly regulated. ${ }^{41}$ Secondly, the document introduced professional and qualification barriers for suppliers. State organizations were mandated to select for contests (tenders, auctions etc.) only qualified participants. Although competition was made mandatory, its forms varied from open to closed, and from one to two stages.

From the normative-legal perspective, the decree was an important step forward in establishing a modern and civilized system of state procurement. However, in practical terms it did not foster improvements. On the one hand, it did not impose procurement regulations on the regional and municipal levels, leaving allocation of substantial parts of budgetary funds without proper control. ${ }^{42}$ On the other hand, the decree "did not spell out the enforcement rules." ${ }^{43}$ Inefficiency of the late 1990s reform was explained by "extremely weak enforcement," regardless of the fact that "the Russian government tried in 1997 to reform public procurement according to the policy advice of international organisations. $" 44$

${ }^{40}$ Decree of the President of the Russian Federation No.30 from April 8, 1997 "O pervoocherednykh merakh po predotvrashcheniiu korruptsii i sokrashcheniiu biudzhetnyh raskhodov pri organizatsii zakupki produktsii dlia gosudarstvennykh nuzhd."

${ }^{41}$ See: Resolution of the Government of the Russian Federation No.1222, from September 26, 1997 "O produktsii, zakupaemoi dlia gosudarstvennykh nuzhd bez provedeniia torgov (konkursov)."

${ }_{42}$ Andrei Ivanov (2011) "Sovremennyi etap razvitiia sistemy gosudarstvennykh zakupok Rossiiskoi Federatsii: "effektivnost"” auktsiona i korruptsionnost' konkursa.", Goszakaz:, No.24.

${ }^{43}$ Andrei Yakovlev and Olga. Demidova (2012) Access of firms to public procurement in Russia in the 2000s. International Journal of Economic Policy in Emerging Economies, Vol. 5, No. 2, p.144

${ }^{44}$ Ibid. 
The next time the idea of modernization of the system of state procurement emerged was as part of the public administration reform. It was not only simply mentioned in the 2005 Conception of the reform, but in order for the reform to succeed, a specific federal law was passed. Obviously, the shift from a presidential decree of Yeltsin's era, to a federal law was an important symbolic act. Law No.94-FZ was initially passed by the State Duma on July 8, 2005 and signed by the president on July 21. The law came into effect on January 1, 2006.

From its very beginning, the law posited that one of the major issues of the newly imposed regulations would be the transparency of the procedures of procurement, as well as averting corruption. ${ }^{45}$ The law established that procurement of goods and services must be done on the basis of open competition between the suppliers. This referred to all contracts that were higher than 60 thousand rubles (or $\$ 2200$ US) ${ }^{46}$ It is also important to note here that the reformers initially took a holistic approach to procurement, insisting on installing a 'one size fits all' regulatory framework, and disregarding quantitative and qualitative differences between goods and services acquired by public agencies. The law in great detail describes procedures of conducting state and public procurement, prescribing responsibilities of each side of the process, as well as outlining their rights. The procedures of submitting orders by public institutions, applying for participation by the private contractors, assessment of applications by specialized commissions,

\footnotetext{
${ }^{45}$ See: Federal Law No.94-FZ from July 8, 2005 “O razmeschenii zakazov na postavki tovarov, vypolnenie rabot, okazanie uslug dlia gosudarstvennykh i munitsipal'nykh nuzhd," Article 1.

${ }^{46}$ Later, in 2007 the limit was raised to 100 thousand rubles (appr. \$3900 US) due to the fact that such a low limit imposed barriers on procurement of minor goods and services.
} 
announcements of offers, as well as establishing the winners, are described in the law in great detail.

A substantial strength of the document was the introduction and formalization of competitive principles of state and public procurement. The law established two major procedures for conducting procurement: tender and non-tender ones. The former type of conducting tenders can subsequently be distinguished on concourses (konkursy), regular and electronic auctions. Procurement without conducting a tender is applicable if there is no competition between the suppliers. In this case, public agencies resort to the procedure known as "quotation inquiry" (zapros kotirovok). Concourses and auctions could be either open or closed.

According to the logic of the reformers, the law No.94-FZ should become the major instrument for conducting state procurement procedures. As it was stated elsewhere "[t]he law received notable political support and was accompanied by a significant rise in public procurements: their volumes doubled between 2006 and 2008, from 1922 bln rubles to 3981 bln rubles. ${ }^{, 47}$ The trend of nominal growth of budgetary expenditures on procurement remained in the following years. Moreover, it did not change during the times of the world financial crisis of 2008-2010, although the rate of growth did slow down, but by 2012 , the aggregate spending on procurement was $150 \%$ of the 2008 level. ${ }^{48}$

In this regard, it is interesting to assess procurement as a percentage to the country's gross domestic product. Figure 1 provides estimates of the volume of state

\footnotetext{
${ }^{47}$ Andrei Yakovlev, et. al. (2010) HSE Policy paper: The system of public procurements in Russia: on the road of reform.. Moscow: Higher School of Economics., p.3

${ }^{48}$ The spending was calculated in nominal prices and does not account for inflation. If inflation is included, then the rate of growth would be lower.
} 
procurement. With sharp growth between 2006 and 2008, it afterwards stabilized at a level of $9-11 \%$ of the GDP. However, the data shown in the graph do not include spending of state owned enterprises, natural monopolies, as well as state and municipal unitary enterprises. If their spending is incorporated, then procurement of the entire public sector would account for approximately $15 \%$ of the country's GDP. ${ }^{49}$

Figure 1. State procurement as a percentage of GDP (in real money).

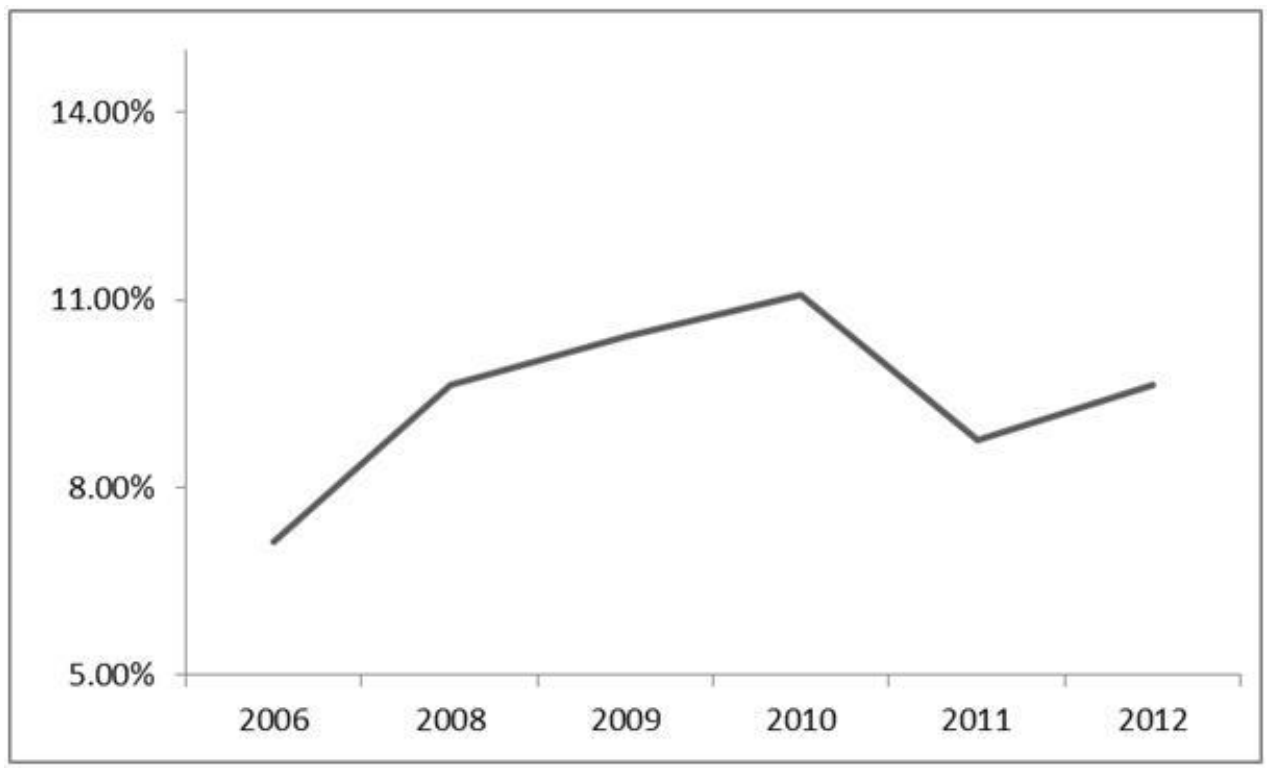

Figure 1 is prepared by the author on the basis of the official data from Rosstat (Russian Statistical Agency).

The data allows several assumptions to be made regarding the system of procurement in Russia in the years that followed the reform-beginning in 2006. First of all, overall growth of quantity and volume of public contracts suggests that implicitly the reform of procurement achieved its objective of establishing an important infrastructure in the given sphere of administrative practices. At the same time, the gradual increase of

${ }^{49}$ These calculations were also approved by the Ministry for Economic Development of Russia. See for example: “Ob”em goszakupok v 2010 godu otsenivaetsia v 15\% rossiiskogo VVP" (2009, November 20) Vedomosti [Online]. Available at: http://www.vedomosti.ru/finance/news/2009/11/20/889349 (Accessed: 26 August 2013). 
budgetary spending on procurement from one year to another should not be overestimated. It coincided with the steady recovery of the national economy, driven by rapidly increasing prices on oil and gas. Secondly, although initially the growth rates of procurement surpassed the growth rates of GDP, by the times of the global financial crisis, the growth stabilized at a particular level as the portion of the GDP. This leads to a suggestion that fluctuations in spending on procurement more or less followed the dynamic of Russian economy. Evaluations of the procurement to GDP ratio, i.e., whether it is big or small, sufficient or otherwise will remain beyond the framework of this analysis as they do not directly reflect problems of efficiency of the created infrastructure. Moreover, this topic seems to be the object of a specific research.

Further analysis is inspired by public discussions on the subject matter of the new infrastructure of state procurement. Since its adoption, law No.94-FZ has undergone numerous independent expert analyses. Most experts were unanimous at pointing out the fact that, despite the proclaimed goals, the law does encourage corruption.

Even some senior public officials publicly warned about this troublesome law. Among them was Sergey Stepashin, former head of the Accounts Chamber of the Russian Federation. He repeatedly addressed issues of corruption that this law had created. In 2008 he stated that this law is among the laws that encourage corruption most. ${ }^{50}$ In 2011 he even suggested a temporary ban on the implementation of this law. He argued that this "law is impossible to be improved and it should be substituted by the

\footnotetext{
50 "Stepashin: zakon o goszakupkakh - samyi korruptsiogennyi” (July 15, 2008) Gazeta.ru. [Online]. Available at: http://www.gazeta.ru/news/business/2008/07/15/n_1243468.shtml (Accessed: August 15, 2013).
} 
federal contractual system." ${ }^{51}$ The reason for suggestion of such a radical actions (e.g., abandonment of the law) is quite remarkable. Stepashin argues that the system of public administration that emerged in the process of reform does not provide necessary conditions for proper functioning of this law. Therefore in this particular case the contractual system does harm rather than improving the situation. His opinion about deficiencies of the system was supported by the country's leaders. Thus, already in 2010 Dmitry Medvedev, then president of the country, confirmed that in the process of procurement, approximately "one trillion rubles was embezzled." ${ }^{, 52}$ Thus, even in the eyes of the country's leader, the level of corruption in the sphere of state procurement constituted nearly 20 percent of the entire budgetary spending in this sphere. Medvedev also stated that the law urgently needs "systemic optimization." ${ }^{53}$ In 2013, Vladimir Putin, who was re-elected president for a third term, also stated that the system of state procurement demanded serious modernization. ${ }^{54}$

Criticism of the system of state procurement from both politicians and experts was accompanied by a series of corruption scandals in which were mentioned names of some top public officials at the level of ministers and deputy ministers. Numerous media

\footnotetext{
51 “Stepashin predlagaet otlozhit' v storonu 94-i FZ i oprobovat' federalnuiu kontraktnuiu sistemu" Interfax. . [Online]. Available at:

http://www.interfax.ru/realty/realtyinf.asp?id=187301\&sec=1461 (Accessed: August 15, 2013).

52 "Medvedev: vorovstvo pri goszakupkakh prevyshaet trillion rublei." (October 29, 2010) Vedomosti. [Online].

http://www.vedomosti.ru/politics/news/1135201/medvedev_vorovstvo_pri_goszakupkah dostigaet_bolee_1 (Accessed: August 15, 2013).

$\overline{53}$ Ibid.

54 “Korruptsia na goszakaze” (March 12, 2013). Oleg Sapozhkov, Petr Netreba (2009).

"'Rosagrolizing' proveriaiut na rastochitelnost'". Kommersant. No.217 (4272), November, 20.

[Online]. Available at: http://www.ng.ru/editorial/2013-03-12/2 red.html (Accessed: August 15, 2013).
} 
reports have been issued mentioning corruption scandals in various ministries and their subordinate agencies. To illustrate the situation, three of the most notorious corruption scandals that attracted major media and political attention will be mentioned in this analysis.

Perhaps, the most politically significant scandal occurred in the administrative structures of the Ministry of Defense. It has already resulted in resignation of the minister Anatoly Serdyukov and arrest of his subordinate, director of the department of property Evgenia Vasilieva. Although corruption allegations in the ministry go well beyond the sphere of procurement, violations in it account for 4.4 bln rubles. ${ }^{55}$ The military Attorney's Office initiated in 2013 more than seven thousand legal cases related to violations in the sphere of military procurement and more than one thousand violators were prosecuted. ${ }^{56}$

The second most remarkable scandal occurred in the Ministry for Agriculture and was related to activities of its subordinate state-owned commercial leasing enterprise "Rosagroleasing". The company was established in 2001 as one of measures of fulfillment of the National Priority Project 'Modernization of the agricultural complex'. In 2009, activities of this enterprise were investigated by the General Attorney's Office of the Russian Federation. The inspection revealed "facts of wasteful appropriation of

\footnotetext{
${ }^{55}$ This statistic was announced by the head of Military Attorney's Office Sergey Fridinskii. For more details see: "Samoi korrumpirovannoi sferoi v armii stalo raspredelenie gosoboronzakaza" (July 11, 2013). RosBusinessConsulting. [Online]. Available at: http://www.rbcdaily.ru/society/562949987828212 (Accessed: August 15, 2013).

56 Ibid.
} 
budgetary funds. ${ }^{, 57}$ The company was accused of using mediators and avoiding signing contracts with the clients directly. It was assumed that approximately $70 \%$ of all contracts were closed using such shadowy schemes. ${ }^{58}$ It was argued that as a result of these malicious practices 39 bln rubles of budgetary funds were misappropriated. ${ }^{59}$ It was alleged that the ex-minister for agriculture Elena Skrynnik was personally involved in the corruption schemes.

This list of public scandals can be continued further. Some of the most notorious examples include the case of procurement of medical magnetic resonance tomography scanners, which appeared even in academic articles. ${ }^{60}$ This case uncovers the scheme of embezzlement and potential allegations of corruption at the regional level (Arkhangelsk oblast in particular), when $70 \%$ more budgetary funds were spent on this medical equipment than in other regions, and indeed this was recommended by the Ministry for Healthcare ${ }^{61}$ Another example would include the most recent inspection of the state corporation "Rosnano", which is being run by Anatoly Chubais, by the Accountant Chamber of the Russian Federation. In its lengthy and detailed report that was issued on May 16, 2013 the auditors concluded that "expenses of the company in the first years of its activity were excessive" and "overall in 5 years 6 bln rubles were spent on administrative and communal expenses, 5,3 bln on office space, 4 bln rubles on [external]

${ }^{57}$ Oleg Sapozhkov, Petr Netreba (2009). “"Rosagrolizing” proveriaiut na rastochitel'nost'”. Kommersant. No.217 (4272), November, 20.

${ }^{58}$ Rinat Sagdiev (2010). "Krupnym planom: Ministerskoe khoziaistvo." Vedomosti. No.17 (2535), February 2.

${ }^{59}$ Rinat Sagdiev (2012). "Ministerskoe khoziaistvo - 2." Vedomosti. No.244 (3258), December 24.

${ }^{60}$ Andrei Yakovlev (2012). "Sistema goszakupok v Rossii: na poroge tretiei reformy." Obschestvennye nauki i sovremennost' [Social Sciences and Modernity]. No.5., pp. 59-60. 61 "Effektivnyi menedzher v belom" (May 24, 2010) Novaia gazeta, No.54 
consulting and expertise. ${ }^{\prime 62}$ It was decided that the results of this inspection would be sent to the General Attorney's Office for further investigation.

Besides issues of insufficient transparency and corruption, the reform of public procurement was aimed at an improvement of efficiency of the process, and an overall reduction of budgetary spending on public administration.

Cross-departmental analysis of statistical data on procurement (Table 1) reveals that in 2012 the average reduction in prices was 8.6 percent. In some instances, as like in the case the Federal Service for Tariffs, the average reduction was 32.53 percent. Almost one third of the federal executive institutions were able to reduce prices of contracts by more than 10 percent in comparison with the initial proposals. Although the mean and the median values are in relatively close proximity to each other, they nevertheless do not provide a sufficient and accurate picture of agencies' performance in the sphere of procurement. Indeed, half of the most efficient executive agencies accounted for nearly 11 percent of the total allocation of budgetary spending on procurement. The situation is rather different on the other side of the spectrum. 61 percent of budgetary funds provided for state procurement were used by 25 percent of federal agencies. Yet their ability to cut expenditures was rather moderate. Average reduction of costs of public contracts in this case was less than 4 percent. In case of appropriation of 75 percent of funds, allotted for procurement, the price of the final contract was reduced on average by only 4.24 percent.

${ }^{62}$ See: Report of the meeting of the Collegium of the Accountants Chamber of the Russian Federation No.20K (910) from April 26, 2013. Otchet o rezultatah kontrol'nogo meropriiatia "Proverka effektivnosti ispol'zovaniia otkrytym aktsionernym obshchestvom "ROSNANO" (gosudarstvennoi korporatsiei "Rossiiskaia korporatsiia nanotekhnologii") sredstv federal'nogo biudzheta, poluchennykh v 2007-2012 godakh, i sootvetstviia raskhodovaniia sredstv ustanovlennym tseliam deiatel'nosti". [Online]. Available at: http://www.ach.gov.ru/userfiles/loadfiles/201305rosnano.pdf (Accessed: August 15, 2013). 
Moreover in some instances initial price of the contract that an agency submits in order to launch the procurement procedures was not optimal. In such circumstances formation of market-based prices for goods and services purchased by public agencies relied heavily on clarity and transparency of the entire process of competition among suppliers.

Table 1. Federal government's cross-departmental statistics of state procurement in 2012.

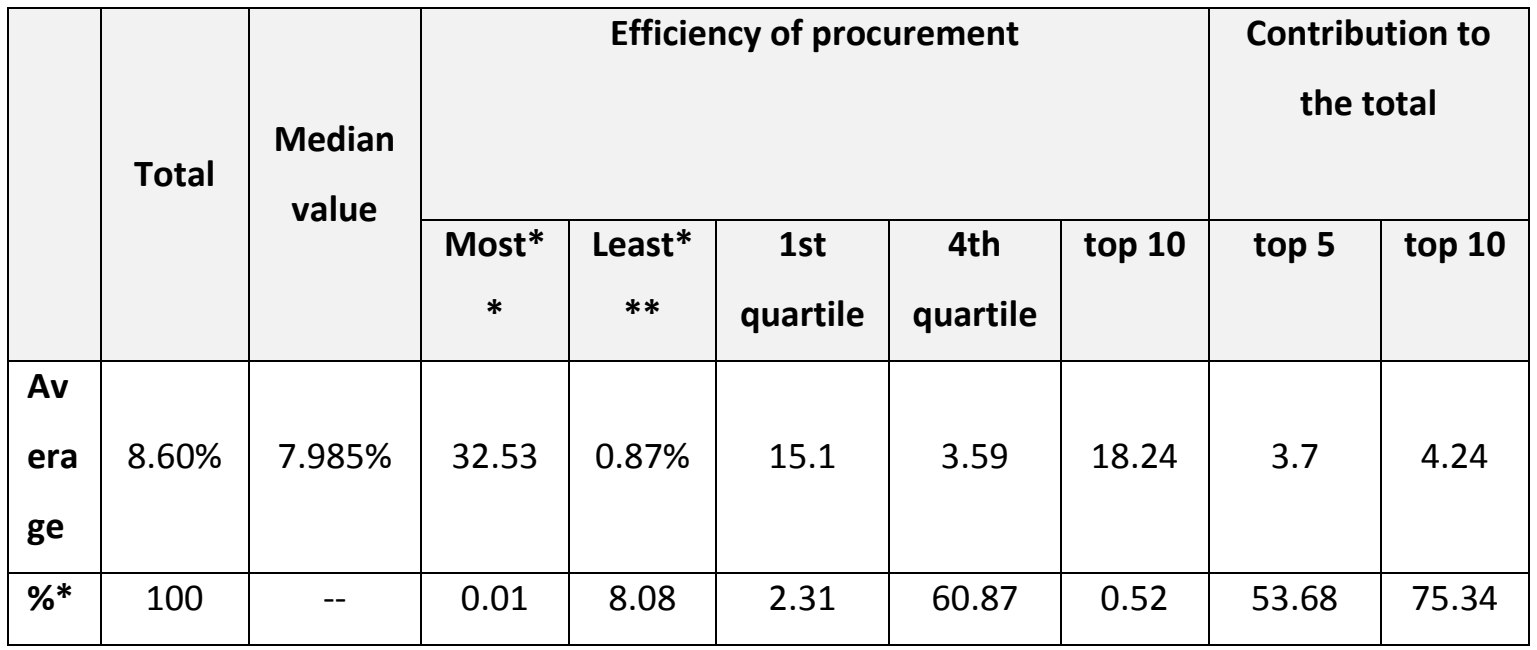

Table 1 is prepared by the author on the basis of data, provided by Rosstat - Russian Agency for Statistical Information *percentage of the total value of procurement, made by the particular public agency ** Federal Service for Tariffs *** Roskosmos (Federal Agency)

Therefore, it will be correct to infer that those agencies that are in the lead in terms of spending usually provide the lowest degree of price reduction. In reverse, significance of those public institutions that achieved the highest rates in reduction of prices during the procurement process is minute. In addition to this aggregate data, Yakovlev et. al. also conducted an analysis that took into account the size of the contracts. Their findings revealed that due to the ruling on the minimum mandatory size of the contract, " $86 \%$ of contracts are related to small-scale purchases (up to 100 
thousand rubles), which only account for $5 \%$ of gross budgetary spending on procurement." 63

These examples evidently show that the system of public procurement, which was established in 2005, does not function properly. The market mechanisms it was designed to rely on do not promote fair and equal competition. The need for more administrative control became obvious several years after the new system became functional. Thus, in 2010 in Moscow, it was decided that public officials, who were involved in procurement, would be interviewed, using polygraphs (i.e., lie detectors). As a result of such inspections $40 \%$ of officials were discharged from their duties in specialized departmental procurement commissions. ${ }^{64}$ In light of the above mentioned corruption scandals, in the public discourse on procurement trust in market mechanisms was replaced by the idea of direct state control.

The situation does not look bright from the side of contractors too. An international Business Environment and Enterprise Performance Survey (BEEPS), conducted by the European Bank for Reconstruction and Development altogether with the World Bank, includes the Russian sample. The survey contains responses of entrepreneurs from different countries on a series of questions, concerning their experience as businessmen and their estimates of the business climate in their country as well as in the world as a whole. Among other topics the survey covers important issues, related to contractual relations between the state and private enterprises.

${ }^{63}$ A. Yakovlev, O. Demidova, O. Balaeva. (2012) Prichiny snizheniia tsen na torgah $i$ problemy ispolneniia goskontraktov., Moscow: Higher School of Economics, p.7 64 "Korruptsia na goszakaze” (March 12, 2013). Nezavisimaia Gazeta. [Online]. Available at: http://www.ng.ru/editorial/2013-03-12/2_red.html (Accessed: August 15, 2013). 
Figure 2. Corruption perception by business community in Russia (BEEPS Survey). ${ }^{65}$

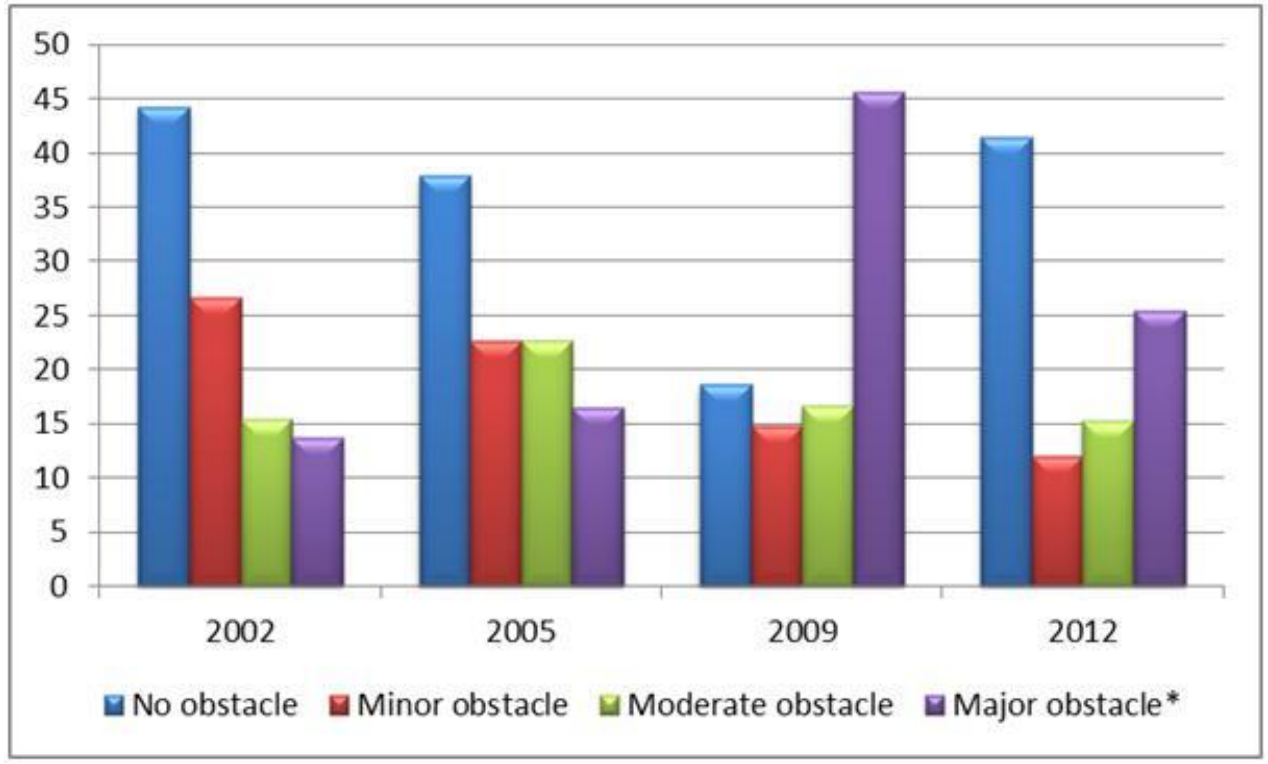

Figure 2 shows the results of the review of the entire sample. Therefore, it allows the comparison of changes in perceptions of businessmen on the administrative climate in the economic sphere. It can be argued that as a result of the reform, attitudes of the business community regarding corruption did not change. Moreover, there can also be traced increasing responses that describe the situation as worsening. Even without taking into account the data from 2009, it is quite evident that the number of respondents who believe that corruption in public agencies in the major obstacle for economic activities increased from $13.7 \%$ in 2002 to $25.4 \%$ in $2012 .{ }^{66}$ The present data shows a distribution for the entire sample. However, if we take into account only those enterprises who participated in state procurement, perception of corruption becomes much more critical.

${ }^{65}$ Figure 2 is prepared by the author, using the Russian sub-sample of Business Environment and Enterprise Performance Survey (BEEPS). Available online at: http://www.ebrd.com/english/pages/research/economics/data/beeps.shtml (Accessed: September 7, 2013)

${ }^{66}$ Actually, beginning in 2009 the question expanded including an additional option for answering: "Very severe obstacle." For comparative purposes in Figure 2 this option was combined with the answer "Major obstacle". 
Respondents also assumed that the role of unofficial gifts as means of interactions with public officials also increased.

A group of Russian experts analyzed changes in the system of state procurement focusing primarily on issues of state-business relations. ${ }^{67}$ The analysis was made in reliance to the phenomenon of "state capture" - a well-developed political theory ${ }^{68}$ that suggests that "powerful firms have been able to capture the state and collude with public officials to extract rents through manipulation of state power." ${ }^{69}$ There was evidence supporting the applicability of this theory to the Russian case during the 1990s. With a resurrection of the state in the early 2000s, the "system of exchanges" became a much more plausible explanation of state-business relations. The "system of exchanges" suggests that the state and business enterprises establish mutually beneficial and stable relations. The model states that public agencies, especially at the regional level, gain access to necessary products and expect economic support from private companies. In exchange, economic enterprises expect to gain access to public funds and, in some instances, even assistance from public agencies in obtaining necessary institutional support. The forms of support may differ from preferential access to public contracts to inclusion of firms in various state projects aimed at developing particular economic sectors by means of budgetary subsidies.

${ }^{67}$ Olga Demidova and Andrei Yakovlev (2012) "State-business relations and participation of firms in public procurement in Russia: an empirical study." Journal of Public Procurement, Vol. 12, Issue 4, pp. 563-588

${ }^{68}$ Stigler, G. J. (1971). "The Theory of Economic Regulation.” The Bell Journal of Economics and Management Science, Vol. 2(1)., pp. 3-21

69 Joel S. Hellman, Geraint Jones, Daniel Kaufmann (2000) “Seize the State, Seize the Day." State Capture, Corruption, and Influence in Transition. World Bank Policy Research Working Paper No.2444. Online: http://papers.ssrn.com/sol3/papers.cfm?abstract_id=240555 Accessed: June 22, 2013. 
Both the "state capture" and the "system of exchange" models create a rather corruptogenic environment that the system of procurement is aimed at modernizing. However, analyzing the practices of state procurement established as a result of the reforms, authors came to a conclusion that the new system was not able to properly address the problematic issues. Researchers state that "[t]oday it is evident that this political decision failed to reduce corruption, and instead, placed a heavy burden of costs on honest participants in government procurements. ${ }^{, 70}$ Some of the evidence from their research implicitly suggests that not only were bureaucrats expecting to take bribes, but also businessmen were willing to pay them in order to gain a competitive advantage and obtain public contracts.

The major responsibility for the failure of the new system of public procurement is laid upon the institutional framework built around law No.94-FZ, as it was not able to satisfy either the customers, or the suppliers. On the suppliers' side the reform was not able to prevent corruption and maintain transparency and equality of the process of procurement. On the customers' (or public officials') side, the reform was not able to provide sufficient instruments to deal effectively with unconscionable contractors. ${ }^{71}$ Therefore, "the demands of 94-FZ not only create problems for bona fide public customers but also fail to attract bona fide suppliers." ${ }^{72}$

\footnotetext{
${ }^{70}$ Andrei Yakovlev, Olga Demidova (2012) Access of firms to public procurement in Russia in the 2000s: before and after radical reform of regulation. International Journal of Economic Policy in Emerging Economies, Vol. 5, No. 2, p.155

${ }^{71}$ This aspect was discussed in great detail in Andrei Yakovlev et.al. (2010) Sistema goszakupok: na puti k novomu kachestvu. Moscow: Higher School of Economics. 72 Andrei Yakovlev et.al. (2010). The system of public procurements in Russia: on the road of reform. Moscow: HSE. p. 9
} 
In this regard, special attention must be paid to the "one size fits all" approach that was put at the core of the reform, as it does not allow for the ability to specify the precise obligations faced by both sides, specifically with respect to the volume of the contract as well as the complexity of the items being purchased. Therefore, in reality the law did not suit anyone's expectations. Rigid and rather detailed procedures, necessary to apply for the public contract, impeded participation of private suppliers in small-scale tenders, as in some cases the costs for participation (e.g. preparing necessary documentation) exceeded the profit margins. At the same time firmness of the provided regulations did not allow necessary flexibility in procuring large and technically complex items. For example, the legislation did not prescribe procedures for making urgent amendments to contracts, even when both sides would be willing to do them. There exists another problem with large contracts that is of delays and even non-completeness of delivery. Yakovlev, Demidova and Balaeva tend to explain this by regulatory deficiencies of procurement procedures, when customers cannot prevent participation of unconscionable contractors. ${ }^{73}$ The latter usually bid for lower prices in auctions than their bona fide competitors, and are often not able to fulfill their obligations.

Imbalances of regulations in the sphere of state procurement were criticized by both participating sides of the process. In some instances, the law started creating shortages in supplies of goods and services that affected large-scale developmental projects, like preparations for the 2014 Winter Olympic games in Sochi ${ }^{74}$ or 2012

\footnotetext{
${ }^{73}$ A.Yakovlev, O.Demidova, O.Balaeva (2011) Prichiny snizheniia tsen na torgakh $i$ problemy ispolneniia goskontraktov., p.13

${ }^{74}$ For example see: Jill Reilly (8 February 2013) 'Ski jump boss SACKED over Russia's winter Olympics delays: Putin axes engineer who let costs soar from $\$ 40 \mathrm{~m}$ to almost \$300MILLION" Daily Mail. Online. Available at:
} 
Vladivostok APEC Summit. ${ }^{75}$ In eight years that followed after its adoption, there were almost four dozens adjustments to the law. These amendments were intended to adjust a rigid and clumsy system to the practical needs of those who were using it. As a result of these actions, the amount of content grew as well, making the law more cumbersome to use. Obviously, such complex and constantly changing legislation was itself the contributing factor for procedural violations, corruption and ineffectiveness of the entire system of state procurement. ${ }^{76}$

Analysis of practices of implementation of the reformed system of state procurement points at one particular explanation for its inefficiency and tendencies to generate corruption. It can be stated that the major reason why the established system did not work as expected lies in a conceptual inconsistency of the reform measures, combined with inadequate preparation of participants to apply the rules and procedures it created.

The explanatory model for the failure of the state procurement system refers to the technocratic principles that reformers adhered to by creating and implementing the reforms of governance (including the one being discussed). Indeed, the approach was able to create a modern infrastructure for conducting procurement. Reformers were able to introduce and launch a unified internet portal www.zakupki.gov.ru, where all procurement orders issues by public agencies were placed and processed. In accordance with the federal program for the improvement of governance by means of a broader use

http://www.dailymail.co.uk/news/article-2275502/Putin-sacks-ski-jump-boss-AkhmedBilalov-Russias-winter-Olympics-delays.html. Accessed: August 28, 2013

75 "Vernut' goszakupki iz zazerkal'ia" (March 1, 2010) Expert. No.8 (694).

${ }^{76}$ Yulia Vasilieva (July 5, 2011) "Potentsial 94-FZ ischerpan" Rossiiskaia gazeta. Online. Available at: http://www.rg.ru/2011/07/05/lihachev.html (Accessed September 1, 2013). 
of automated internet technologies (e-government), the reformers were able to achieve substantial improvements in terms of procedural transparency of the procurement process.

Yet, another aspect of the technocratic approach was the unification and standardization of procedures that made the procurement process rather unresponsive and non-adaptive to situational changes. At the same time, the reform left public officials a substantial administrative capacity in terms of making decisions regarding the type and quantity of procured goods. Thus in the case of procurement reform, the "one size fits all" approach was accompanied by the "let managers manage" ideology. In terms of New Public Management, operational freedom for public officials was needed for improvement of quality and efficiency of the public service. However, in the case of Russia, this approach was misused. Quite often budgetary funds were used for implicit enrichment of public officials by means of procurement of expensive and luxury goods. Most notorious examples like the infamous "golden bed" for the Ministry of Interior Affairs for $4.4 \mathrm{mln}$ rubles (appr. US $\$ 150$ thousand) or specially designed tablet computer for the director of Gazprom for $120 \mathrm{mln}$ rubles (appr. US $\$ 3,5 \mathrm{mln}$ ) became the major country-wide public scandals. ${ }^{77}$

Most evidently, the situation is illustrated with the example of procurement of automobiles for the needs of public officials. There are multiple cases, when various public agencies place orders for cars. Quite often, the cars requested can be referred to as

\footnotetext{
${ }^{77}$ For the Ministry case refer to: "MVD zaplatit 25 millionov rublei za otdelannye zolotom krovati" (August 19, 2009). Lenta.RU, Online at: http://lenta.ru/news/2009/08/19/gold/ Accessed: September 1, 2013. For the Gazprom procurement case please see: "Planshet dlia Millera po tsene vertoleta" (July 16, 2013). BusinessFM. Online: http://www.bfm.ru/news/222405?doctype=article. (Accessed:
} September 1, 2013). 
the luxury segment of brands and top of the line models (like Mercedes S-class, BMW 7series, Lexus LS, etc.) the price tags of which often exceed 4-5 mln rubles (US \$120-180 thousand) ${ }^{78}$

There are no immediate statistics available that provides the complete list of automobiles purchased by state organs, regardless of the fact that all this information is not only collected and stored by the statistical agency 'Rosstat', but it is also open to the public in principle (as far as procurement involved placement of orders in the portal). One can only speculate as to whether this was done on purpose, or inadvertently. Yet, other cumulative statistics, such as total amount of procured goods, average reduction of price, etc. are being presented on the official internet portal. However, some nongovernmental organizations, ${ }^{79}$ as well as journalists, have been monitoring procurement of some items. They reported on some orders that were processed through the system and may be considered redundant. ${ }^{80}$

Whereas some cases of improper use of public funds may lie within the legal boundaries and refer more to the ethical issues as well as problems of political and civic control, there were clear violations of procedures that can be assumed criminal. Experts

\footnotetext{
${ }^{78}$ Yulia Balashova (March 9, 2011) “GOSZAKUPKI. Na kakikh avto sobiraiutsia ezdit' chinovniki” Novaya Gazeta, No.24.

${ }^{79}$ Here, for example could be mentioned RosPil - an organization focused on monitoring corruption in the public agencies, that was created by the famous opposition politician Alexei Navalny. Its website: http://rospil.info/ (available on Russian only).

${ }^{80}$ For example Forbes magazine published an article where presented 11 most extravagant procurement orders. Among them can be mentioned the rug that is 6 kilometer long for $6.4 \mathrm{mln}$ rubles (appr. US \$210 thousand) (order placed by the FSB), or the set of luxury furniture for $10.8 \mathrm{mln}$ rubles (appr. US $\$ 350$ thousand) (administration of the president of Chechnya). For more detail see: "Chinovnich'ia dolia: 11 samykh neozhidannykh goszakazov" (May 29, 2013). Forbes. Online: http://www.forbes.ru/forbeslife-photogallery/pokupki/239829-chinovnichya-dolya-11samyh-neozhidannyh-goszakazov/photo/1 Accessed: September 1, 2013.
} 
point out cases when purposeful grammatical mistakes were made in procurement orders. The consequence of such misdeeds would a guarantee of the virtual impossibility for suppliers to find the given order in the system using embedded search instruments, unless they were made aware of the specific mistakes. For language sensitive search engine of the official procurement internet portal, changing some letters that are similar in both languages, like "k", "a", etc., could make an order, typed with such deliberate mistake invisible for those suppliers who are not aware of the mistake. ${ }^{81}$ One example may illustrate this case. The car manufacturer's name "Mercedes-Benz", when it is translated into Russian, has one letter "c" (in Russian letter 'c' sounds like English 's') that looks exactly the same in both languages. Therefore, using English ' $c$ ' while translating the entire brand-name into Russian will make the search engine miss this particular order in the search request.

The above mentioned cases provide evidence of the fact that the state capture concept is indeed applicable in the Russian case. Yet, this state capture is of a particular form. In this case, Russian institutions of the state are captured not by external agents (like economic organizations), but by the bureaucracy itself that behaves in this way as a corporate unit, using the state and its institutions in their own favour.

It may be argued that the system of procurement, created as a result of the reform, is the primary cause of its own malfunctioning nature. The tendency to emphasize transparency and procedural rigidity of the system, as well as the major goal of the reform being stated as the reduction of the initial order price by means of competition

\footnotetext{
${ }^{81}$ This issue was mentioned in: Mikhail Bocharov (July 31, 2012). "Sotrudniki MVD ostalis' bez formy" KommersantFM. Online at: http://www.kommersant.ru/doc/1992462., Accessed: September 1, 2013.
} 
between multiple suppliers, left other issues of the procurement process unnoticed. The law does not pay substantial attention to issues of administrative control over the formation of procurement orders. Within the established system public administration, officials were given operation freedom to make decisions that, in theory, would result in more efficient fulfillment of state functions. In reality it resulted in officially admitted corruption that accounts for nearly 20 percent of the entire spending on procurement, as well as no substantial improvement in the quality of public services, according to the international indicators.

It is crucial to take into account the fact, that in this situation, corruption is likely to be the derivative of more fundamental systemic issues that are embedded into the system of Russian public administration. It may be argued here that vertically integrated political-administrative organization of the state does not meet the necessary requirements for successful installation of NPM-oriented procurement mechanisms.

Table 2. Nomenclature of goods and services procured by public administration divisions. ${ }^{82}$

\begin{tabular}{|c|c|c|c|}
\hline Type of procured goods/services & 2011 & 2012 & 2013* \\
\hline $\begin{array}{l}\text { Construction, development and maintenance of real } \\
\text { estate and transport infrastructure }\end{array}$ & $39.20 \%$ & $41.61 \%$ & $38.34 \%$ \\
\hline Industrial architecture, engineering, and R\&D & $5.48 \%$ & $5.36 \%$ & $5.59 \%$ \\
\hline Intellectual services, research and consulting & $7.34 \%$ & $5.30 \%$ & $5.17 \%$ \\
\hline Medical equipment & $3.48 \%$ & $3.96 \%$ & $2.79 \%$ \\
\hline Water and heating & $2.34 \%$ & $2.01 \%$ & $3.43 \%$ \\
\hline Cars and parts & $1.85 \%$ & $1.40 \%$ & $1.81 \%$ \\
\hline Electricity & $1.60 \%$ & $1.36 \%$ & $2.36 \%$ \\
\hline Computers, electronics \& IT & $1.33 \%$ & $1.33 \%$ & $0.75 \%$ \\
\hline
\end{tabular}

${ }^{82}$ Table 2 is assembled by the author on the basis of official data, presented on-line at: http://zakupki.gov.ru and 


\begin{tabular}{|c|c|c|c|}
\hline Financial services & $1.17 \%$ & $1.26 \%$ & $2.19 \%$ \\
\hline Transportation & $1.16 \%$ & $1.17 \%$ & $1.10 \%$ \\
\hline Communication services & $1.05 \%$ & $0.93 \%$ & $0.95 \%$ \\
\hline Healthcare services & $1.04 \%$ & $0.96 \%$ & $1.10 \%$ \\
\hline Other** & $34.56 \%$ & $33.35 \%$ & $34.42 \%$ \\
\hline Total & $100.00 \%$ & $100.00 \%$ & $100.00 \%$ \\
\hline \multicolumn{2}{|c|}{$\begin{array}{l}\text { * The data for } 2013 \text { is shown for the time period from Jan.1 to } \\
\text { Aug. } 24\end{array}$} & & \\
\hline \multicolumn{4}{|c|}{$\begin{array}{l}\text { ** "Other" includes the entire nomenclature of goods/services purchased by the } \\
\text { public agencies excluding those, presented above. With few exemptions each cat } \\
\text { of goods/services included in "Other", accounts less then } 1 \% \text { of the total annual } \\
\text { expenses on state procurement. }\end{array}$} \\
\hline
\end{tabular}

NPM administrative technologies that demand operational flexibility for public officials as the means for efficiency improvement imply the existence of civil and political control. However, the political system of the 'power vertical' in Russia focuses on administrative issues that are unable to enhance control in the sphere of public procurement. Complications of the vertical integration in management of state procurement are revealed with respect to the fulfillment of controlling functions as well. As is stated elsewhere, the reformers recognized the hazards of excluding mid- and smallsize enterprises from competition. This itself could impose serious risks for the major goal of the reform, namely the reduction of public spending. Thus the minimum threshold for public orders was initially set at 60 thousand rubles, meaning that any purchase to be made by a state organ above that limit demands an auction. Obviously, this created a significant burden for the controlling organizations, as they had to put their man-days on investigation of these small-scale deals that attributed for nearly 90 percent of all orders. Yet their aggregated value barely exceeded $6 \%$ of the total value of all purchases made 
for the same controlling period. The administrative resource that has become the major source of political change was dissipated, significantly reducing the potential for control.

As Andrei Yakovlev argues, one of the major drawbacks of the reform was the rigidity of its legal and structural framework that "did not allow separating interests and stimuli of conscientious and unconscientious state customers." ${ }^{" 83}$

The technocratic approach that was adopted by the reformers showed opposite results. It was expected that new procedures of state procurement would simplify companies' participation in tenders and auctions. Yet the research that was conducted by specialists of the Higher School of Economics, who interviewed businessmen, revealed that in fact, almost half of respondents outlined negative effects of the reform. ${ }^{84}$ Three questions directly signified negative trends: 1) procedures of applying have become more complicated (20,3\% of respondents); 2 ) general expenses of participation in tenders have risen $(15,3 \%) ; 3)$ participation in competition has become less profitable $(11,8 \%)$. In addition to those who marked an increase of opportunities for unfair competition $(14,3 \%)$ the aggregate number of entrepreneurs who negatively assess the changes, approximates $2 / 3$ of the total number of respondents.

It must be mentioned here that law No.94-FZ regulates relations in the sphere of state procurement, whereas public procurement is being regulated by another federal law No.223-FZ. This law "On procurement of goods, works, services by some types of legal entities" prescribes procedures of procurement of state companies and corporations, natural monopolies, state and municipal unitary enterprises, or, in other words, economic

${ }^{83}$ Andrei Yakovlev (2012). "Sistema goszakupok v Rossii: na poroge tret' ei reformy." Obshchestvennye nauki i sovremennost' [Social Sciences and Modernity], No.5, p. 59. ${ }^{84}$ The poll was conducted in Spring-Summer of 2009. 
agents that in any form have public agencies as their (co-) founders and/or (co-) owners. Although these entities are not direct objects of analysis in this dissertation and, moreover, they are regulated by the different legislature, the situation in the sphere of procurement of the needs of these organizations provides additional evidence of malpractices of public officials and/or hired managers in charge of public corporations, due to imbalances of the current system of political-administrative control.

Figure 3. Distribution of settled contracts according to the type of used procurement
procedure in $2012^{85}$

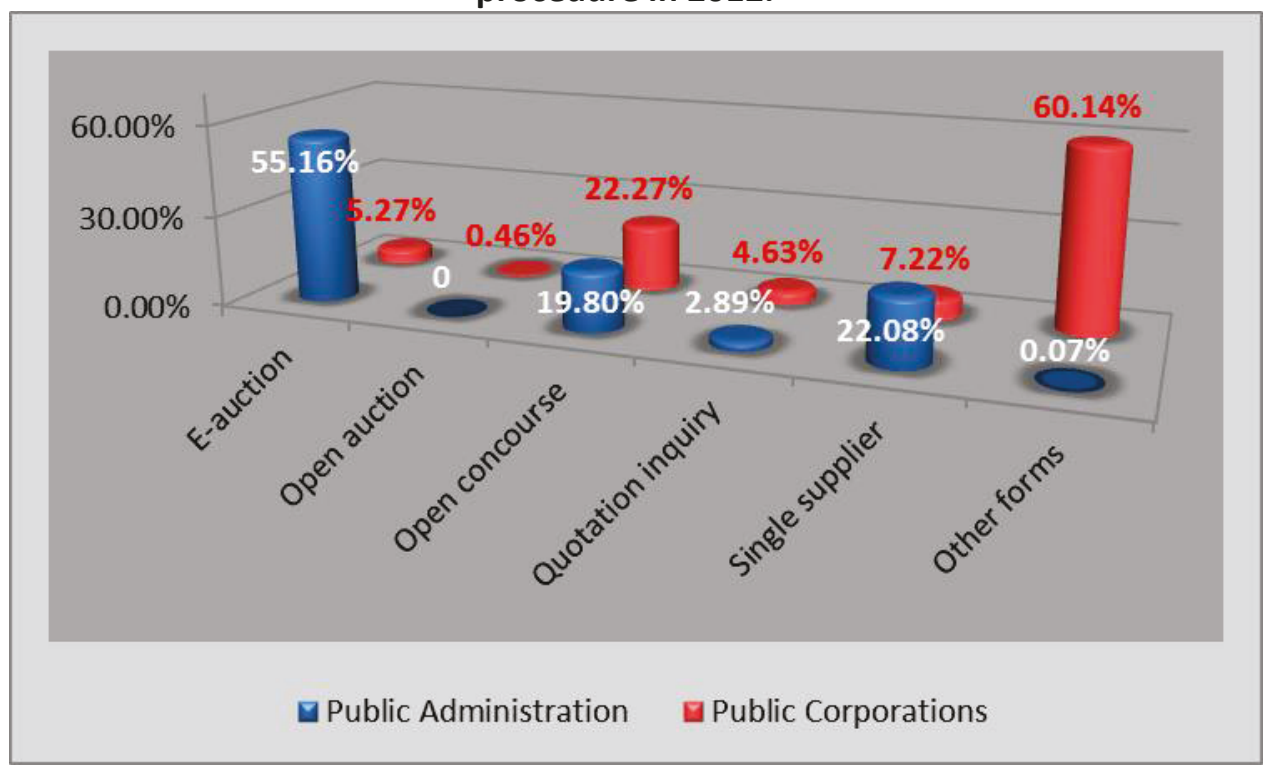

Figure 3 reveals substantial differences in procurement practices that were used by institutions of public administration and public corporations. This comparison of procurement practices points at the rather significant aspect of administrative (or managing) practices of employees hired by public organizations. Actually, public economic enterprises are given more procedural freedom in decision making, regarding the types of orders they could use. And the fact that their managers tend to resort to other

${ }^{85}$ Figure 3 was created by the author, using the official statistical data, available at the official internet portal for the system of public procurement. [URL: http://zakupki.gov.ru] In case of public organizations data on open auctions was unavailable and all auctions were treated as E-auctions. 
forms of procurement than open and transparent electronic auctions is rather remarkable. It actually contradicts the logic of economic performance, based on the free market model. It should be expected that public managers, who run large public enterprises, would behave in order to maximise profits of their shareholders. Furthermore, such maximization goes hand in hand with open competition. Instead, just above 60 percent of the total amount of contracts were allocated using neither auctions, nor open concourses. This ultimately leads to a conclusion that the market mentality, which was heavily relied on by the technocratically minded reformers, does not prevail in Russian administrative culture. Therefore, it can be assumed that in the case of public administration agencies, wide use of open competitive procurement practices is being driven by the mandatory requirements and not by the logic of efficiency improvement.

Further deliberation on the subject matter leads to the conclusion that it is inappropriate to predominantly rely on simply developing an infrastructure of the reform process for state procurement-as the reformers did in this case. In given politicalcultural circumstances, a considerable degree of operational freedom in conducting procurement that was granted to public officials by the legislation, did not foster efficiency. And the fact that in some instances, the starting price of the auction could be made considerably higher than it really should be, scales down the marginal efficiency that is shown as result of the competition.

The situation was reflected in the official report issued by The Accounts Chamber of the Russian Federation. The Chamber reviewed 458 of the largest (over 1 billion rubles) contracts, signed by Russian public agencies during the period from July 1, 2011 to December 31, 2012, the cumulative value of which exceeded 1.5 trillion rubles. It 
stated that these contracts were rather "important and significant in terms of its volume segment of state procurement." ${ }^{86}$ Yet as the audit revealed, "more than 70 percent (in quantitative and monetary aspects) of contracts were assigned avoiding competitive procedures by means of signing contracts with the sole supplier." 87

The modernization of the system of state procurement as a part of the reform of public administration is considered in this dissertation under the aegis of the NPM approach as it directly refers to both major reform objectives. On the one hand, the optimization of state procurement should lead to a reduction of budgetary expenses for supplying the state apparatus. On the other hand, such optimization should be accompanied by the fact that the state is no longer directly involved in the production of goods and services that it uses in its operations, but rather purchases them from private or semi-private contractors.

Again, as with the majority of reform measures, the modernization of procurement was resolved in a rather technocratic manner. The technocratic approach emphasized establishment of the normative and legal framework. It looks like that reformers overlooked the notorious 'human factor', or did not take into account potential malpractices that could emerge when the normatively oriented design of the reform gets into action. As it was expected, the proper infrastructure and legal framework would create a sufficient basis for implementing the proper procurement procedures. In this

86 "Schetnaia palata vyiavila narusheniia v sfere osushchestvleniia osobo krupnykh gosudarstvennykh zakupok." The Accounts Chamber of the Russian Federation. August 15, 2013. (Online) [URL: http://www.ach.gov.ru/ru/news/15062013/]. Accessed: August 26, 2013.

${ }^{87}$ Ibid. 
case, the legislation focused on creating solid and mandatory rules that act as a step-bystep guide for the entire process.

However, this system proved to be insufficiently efficient. As was posited in theory and later confirmed in the practical study conducted by experts from the Higher School of Economics, reliance upon the legal-infrastructural aspects of the procurement system might address issues of transparency of the process of procurement itself. This, in return, might have a positive effect on reduction of corruption, if the designated government agencies would enforce control in this sphere and undertake necessary actions in response to the emerging cases. At the same time, the technocratic approach does not take into account the adequacy of the results of procurement. Not only public organizations might receive products at the best price; the very necessity of procurement of particular goods (as in the situation with luxury vehicles) must be put under scrutiny.

Thus, public officials, who are responsible for procurement, also tend to see the process in technocratic terms, i.e., to follow the instructions precisely, fulfill all legally prescribed mandatory procedures, sign a contract with the bidder who has given the smallest price, and obtain the desired goods or services. At the same time the procedure does not regulate what exactly is procured and whether there is need for exactly this kind of product. This not only results in some loud public scandals, discussed above, but also and even more importantly, leads to an increase of budgetary expenses related to state procurement, making the reform efforts obsolete.

The move from traditional planned principles of procurement to more discretionary principles of supplying public agencies with essential products has been substantially biased by the nature of political process in Russia. Cultivation of the top- 
down political-administrative culture alongside a downscaling of the significance of civil control fosters a situation when state agencies tend to allocate public resources inefficiently. In addition, the system does not explicitly posit the benefits for efficient use of budgetary resources. Public officials are not praised for substantially reducing their expenses. Nor are there clear mechanisms of punishment for inefficient use of resources. The technocratically designed system of control manifests a reduction in expenses, which were made in comparison with the initially requested prices. Moreover, as the data reveals, the most expensive purchases show the smallest percentage of price reduction.

It appears that the major advantage of the system of procurement that was established by federal law No.94-FL would be the fact that, as Andrei Yakovlev et. al. posited, "the system of state procurement was settled as an institution. ${ }^{, 88}$ However, its contradictory results do not allow the consideration of the reform as a success. Moreover, in 2014 this law is going to become defunct and be replaced by a new one. The new law No.44-FZ with the same title was passed on April 5, 2013. Unlike the previous document, this law includes such important procedures of state procurement as setting the norm and nomenclatures of goods and services that an agency is capable of purchasing, further enhancement of procedures of approval of orders from public agencies, and the introduction of mandatory public hearings regarding some groups of goods and services, purchased by administrative institutions. These mechanisms of control, including civil society, were missing in the previous edition, making the discretionary decisions of public officials regarding procurement quite biased.

${ }^{88}$ Andrei Yakovlev, et. al. (2010) Sistema goszakupok: na puti k novomu kachestvu. Moscow: Higher School of Economics., p.4 


\section{Outsourcing in the Russian government sphere}

Another reform feature that totally rests upon New Public Management ideology is outsourcing. Being born within the theory of management, methods of outsourcing extended well beyond the private sector and became almost an omnipresent feature in modernized governments around the globe. It has two fundamental ideological premises in its core. First of all, it states that specially trained and qualified personnel who focus on one particular task are a much more efficient method of fulfilling the task than personnel who perform multiple tasks at once. Secondly, it is much more efficient to transfer some such particular tasks to outside contractors who would not only perform these tasks more efficiently, but would also lead to a reduction of costs through competition.

Outsourcing became a prevalent feature of the production process in modern business organizations. It is used in production cycles when large companies, who are involved in manufacturing very complex equipment, procure parts from independent contractors on a competitive basis. At the same time, outsourcing expanded to the sphere of office management and business administration, leading to such tasks as accounting, planning, and consulting to be implemented by private contractors. Such models of management showed their efficiency and started to be used by governments.

Over the last couple of decades, outsourcing has become an integral part of the contemporary model of governance. It is being used extensively in all countries that have implemented a modernization of their state apparatuses. Obvious leaders are the same countries that advanced further in the adoption of NPM administrative technologies. Making decisions regarding the use of outsourcing, public administrations focus on either 
an improvement of the quality of services provided, or a reduction of the costs of fulfilling particular functions.

The NPM based reform agenda, as proposed by the reformers, included outsourcing as one of the main forms of increasing the efficiency and cost effectiveness and of the civil service from the beginning. Outsourcing was conceptually denoted in the 2005 Conception of administrative reform, which emphasized outsourcing as a necessary aspect of the modernization of state institutions in Russia. The Conception described outsourcing as very close to its classical definition as "a mechanism of withdrawal of some types of [public] activities outside the boundaries of authority of public agencies." Reformers also outlined the spheres in which outsourcing was desirable. They included: the introduction of information technologies, property management, human resources management, as well as financial and accounting services. Moreover, the absence of instruments of outsourcing in these spheres was named as a major impediment to the improvement of efficiency of public administration in the country.

Looking at outsourcing as a necessary form of administrative control, government administration experts undertook an attempt to systematize functions that were performed by government institutions and could be outsourced to outside contractors. The analysis of functions to be outsourced, as conducted by experts from the Ministry of Economic Development and Trade and the Higher School of Economics, was organized into a pyramid of outsourcing initiatives. ${ }^{89}$ The top of the pyramid was conceptualized as

${ }^{89}$ For more details please refer to: Andrei Klimenko et.al. (2007) A report on the conducted research: "Razrabotka mekhanizma autsorsinga administrativnoupravlencheskikh protsessov organov gosudarstvennoi vlasti, vkliuchaia protsessy upravleniia informatsionnymi tekhnologiiami, v ramkakh formirovaniia sistemy 
outsourcing of liquidated government functions. The second step of the pyramid was the outsourcing of administrative processes. The experts also highlighted 'resource outsourcing' and 'one off outsourcing' or specific task based contracts, as the next two steps of the pyramid. This pyramid in principal describes both the tasks and functions designated in the plan of the reform. At the same time it is critical to note that the use of outsourcing demands a wider methodological approach. Namely, this pyramid deals only with governmental functions, there could also be specific auxiliary functions tied with the provision of duties of government institutions that should also be included.

Firstly, it is possible to highlight specific clusters of duties which are inherently intertwined with the fulfillment of functions by government institutions. In this case, this means that parts of some government functions should be transferred to private organizations. At the same time, the current form of outsourcing should not be considered as a type of optimization and limitation of government functions. Optimization of government functions is the cornerstone of the whole administrative reform. In order to solve this problem, specific measures, based on an analysis of the functions of government institutions, which were either excessive or duplicates, was undertaken in the very beginning; similarly, administrative measures were undertaken to liquidate functions that were recognized as excessive by the Commission of the reform. In specific circumstances, namely when a function was recognized as socially important, yet at the same time the necessity of fulfilling this task by government institutions was called into

trebovanii $\mathrm{k}$ ispolzovaniiu informatsionnykh i kommunikatsionnykh tekhnologii $\mathrm{v}$ gosudarstvennom upravlenii". Moscow: Higher School of Economics. (Online) [URL: http://aisup.economy.gov.ru/niokr/downloadfile?uuid=pprtflfs000080000hgp6t522kascjtc ], Accessed: September 29, 2013. 
question, a decision to transfer it for fulfillment by a self-regulating organization was made. Decisions such as these however, do not really fit into the classical use of the term of outsourcing. It is more proper to refer to this as curtailment of excessive government regulation.

Outsourcing of government functions firstly implies the maintenance of government responsibility for the provision of this or another function, as well as the control over quality standards and the term for completion. Within this context, the decision to outsource a function is undertaken with the goal of optimizing government expenditure and the improvement of the quality of servicing this function. More importantly, unlike the transfer of functions to self-regulating organizations from which the government becomes almost completely independent, outsourcing maintains government responsibility and control for the provision of the outsourced services. Hence the government does not lose control of this function, but simply provides a more optimal form of its realization.

Secondly, it is important to highlight tasks of providing effective functioning of government institutions that are not directly linked with the fulfilment of its main functions. The provision of government functions includes not only the questions of providing these institutions with necessary equipment and materials, but also the provision of expert examination, preparation of analytical reports, and other tasks. In this way, the provision of functions of government institutions can be divided into two main groups. The first group includes 'blue collar' functions, directly related to material and technical services provided for government institutions. Provision of services related to the office building, janitorial, transportation, or other services, are the tasks which make 
up this group. Also included within this group are administrative tasks such as financial accounting. While these tasks are more intellectual by their very nature, they are related to servicing the government institution itself and not the fulfillment of the institution's main functions. The second group includes tasks which directly relate to the proper fulfilment of functions by specific government institution. The given spectrum of tasks is thus quite vast. It includes tasks of analytical and expert examination which accompany decisions made by government institutions, execution of a whole range of specific tasks related with the formation of infrastructure necessary for effective fulfillment of functions by the government institution in question. Tasks included in this group include outsourcing IT functions, provision of functional or technical support for the website, and numerous other tasks.

Within the theoretical and methodological context, outsourcing opens a wide range of opportunities for modernization of the state apparatus. From one point of view, reformers could use outsourcing to curtail the size of government and reorganize specific functions to be conducted on a contract basis. In this way, a quantitative decline of the size of the civil service could be achieved — a populist goal which is often vocalized by top tier politicians when they address problems of government. From another point of view, outsourcing allows government institutions to more effectively introduce new technologies of governance, such as the organization of the e-government model. In these types of situations, greater efficiency is achieved because of access to technologies, the experience in which is lacking from government institutions. In this way, government institutions may escape symbolic problems, such as an increase in the size of the civil service, or of exceeding task deadlines tied to problems of hiring and training of new 
personnel. At the same time, outsourcing allows governmental agencies to use the efficiency of the more competitive private sector, thus selecting the most optimal and cost-effective bidder to perform the outsourced function.

Despite the extensive evidence of the effectiveness of this method, and also given the wide base of experience in utilizing technologies of outsourcing in both the private and the government sector, problems with the adaptation to Russian realities were quite significant, and must have been accounted for in the process of developing a methodology and plan of reform for this sphere. Firstly, it was necessary to determine the type of methodology and processes of outsourcing in government institutions. Experts proposed three main models: cluster based, centralized, and decentralized.

Within the framework of the first model was the proposal to denote clusters of similar functions within various public institutions, organize their subsequent unification, and enable their outsourcing to external organizations. In this way, it is possible-for instance - to transfer accounting and financial type tasks to acting private subcontractors. The secondary — a centralized model-implies cross-departmental unification and clear demarcation of functions and tasks which could be outsourced. This type of model maintains a high level of control over the whole process. It also allows the creation and utilization of unified quality standards and effective methodologies of outsourcing within different governmental structures. Finally, the third-decentralized-model of outsourcing, implies the adoption of individual decisions about the size and types of government functions that are capable of being outsourced. The privilege of this approach stems from its flexibility and potential optimality of utilizing technological outsourcing, especially as it allows the consideration of specific goals, tasks, and 
functions of government institutions. Considering all the pros and cons, experts of the Higher School of Economics and the Ministry of Economic Development and Trade proposed utilizing the centralized model of outsourcing. This model also closely corresponds to the principal of the power vertical, which partially explains why it was proposed.

It must be stated, however, that the introduction of outsourcing created some complications in delineating various managerial aspects of the reform of public administration. On the one hand, outsourcing conceptually resembles state procurement. On the other hand, it is deeply intertwined with one of the major features of the reform, namely optimization of state functions and a reduction of state regulation. Saying this, it seems very important to separate state procurement and outsourcing. Indeed, these two aspects of the reform of public administration are very close, and many aspects of outsourcing, especially its contractual form are processed in the system equally. Moreover, all private-public contractual relations, including outsourcing and procurement, are regulated by the same legislation. ${ }^{90}$ However, both aspects must be treated as conceptually separated aspects of the reform.

Whereas the state procurement reform is focused on building of an efficient and transparent system of supplying public agencies with everything that is necessary for them to perform their duties properly, outsourcing measures aims at substitution, where possible, of the public service by the private sector solutions. In case of state procurement, the major emphasis is on the impracticality, or even the impossibility for the state apparatus to adopt a self-sufficient modus operandi and produce everything that

${ }^{90}$ The federal law No.94-FZ is the major legislation in this regard. 
it needs on its own. At the same time, outsourcing envisages a rather different aspect of government, deeply intertwined with the "steering, not rowing" ideologemme. Such a rather radical understanding of the ideological background of outsourcing partially explains its procedural underdevelopment in the Russian case. In the last ten years since the beginning of the reform, the state apparatus has been growing extensively, as well as in terms of its ability to guide political and socio-economic processes in the country, thus becoming the most influential institution in the Russian political and economic spaces.

Moreover, the underlying understanding of a contractual agreement differs in the cases of state procurement and outsourcing. The former is primarily focused on an economy of budgetary funds, i.e., necessary goods of the demanded quality should be procured at minimal cost. The fact that state institutions are not designated to produce this sort of goods or services for themselves is generally taken for granted. The primary focus of outsourcing is the rationale of cost-effectiveness, or, in other words, whether it will be more efficient to transfer particular state functions (or separate administrative processes) to private contractors, or the consequences of such decisions might exceed the initially expected benefits. In this regard decisions regarding outsourcing are inherently political, whereas procurement is more an issue of economic appropriateness.

Further analysis of the procedural aspects of using outsourcing reveals that, according to Russian legislation, there are two legal and organizational forms of transferring of state functions to the private sector. Agreement to outsource a particular aspect of administrative practices can be made in the form of either a state contract or state assignment ('gosudarstvennoe zadanie'). The contractual form of outsourcing is in many legal and regulatory aspects similar to the contractual state of procurement. It is 
also managed under the aegis of the same federal law No.94-FZ. State institutions that decide to transfer some of its duties to private organizations must follow the same procedures and use the same infrastructure as if they were preparing a procurement order. Moreover, unlike procurement that is inherently situational, outsourcing implies the establishment of long-term relations between the public and private sectors. Procurement refers to the current needs of public institutions in order for them to fulfil their duties properly. It is usually framed by the current budget restrictions. Orders are formed and placed on the basis of existing funds. Outsourcing, and especially the one that involves transferring of state functions or administrative processes, implies the establishment of perennial relationships. Private organizations that are involved in the fulfilment of state functions must also meet the criteria of quality imposed by that the state. Unlike with procurement, public institutions and contracted private enterprises must be in constant and productive dialogue in order to make necessary adjustments and reflect on the changes of political, economic and social environments. Therefore, such relations demand the introduction of flexible, yet well regulated forms of partnerships.

The form of state assignment is regulated by the different law No.83-FZ. ${ }^{91}$ The law introduced important amendments to the Budget Code of the Russian Federation (Articles 6, 69.2, 78.1) and the Federal law No.7-FZ "On Non-Governmental Organizations" (Article 9.2). Article 6 of the Budget Code defines state assignment as "a document constituting demands for the composition, quality and/or capacity (of the contents), condition, sequence and results of provided (municipal) government services

\footnotetext{
${ }^{91}$ See: Federal law No.83-FZ from May 8, 2010. "O vnesenii izmenenii v otdelnye zakonodatelnye akty Rossiiskoi Federatsii v sviazi s sovershenstvovaniem pravovogo polozheniia gosudarstvennykh (munitsipalnykh) uchrezhdenii."
} 
(or performed tasks)." ${ }^{92}$ It also provides thorough regulations of this sphere as the assignment must contain clear indicators of quality and the scope of state and municipal services provided by the particular public institution. Assignments are approved by the designated public institutions that are named "constitutors" as their function in this process is to dispose budgetary funds. Therefore, at this level, decisions on whether or not to resort to outsourcing, are made. Unlike general budgetary funding, state assignments allow the targeted allocation of public funds. In theory, this should allow the avoidance of unnecessary expenses, as far as the entire process is highly regulated. On the other hand, the usage of state assignments for outsourcing purposes does not provide sufficient incentives for more efficient utilization of public resources. Detailed regulations regarding the allocation of resources also limit the decision-making flexibility of contractors.

Having the designated procedural limitations in mind, it may also be stated that these limitations potentially create a situation where there will not be enough private contractors, willing to take the tasks that the state plans to outsource. In this regard, excessive regulation of outsourcing resembles the state procurement cases, where the costs of properly prepared documentation needed for participation in auctions result in absence of private firms willing to take part in the process.

Figure 4. The outsourcing matrix

\begin{tabular}{|c|c|}
\hline \multicolumn{2}{|c|}{ Methodology of the reform } \\
\hline decentralized & cluster \\
\hline \multicolumn{2}{|c|}{ Legal-administrative forms } \\
\hline state contract (Law No.94-FZ) & state assignment (Law No.83-FZ) \\
\hline
\end{tabular}

92 Ibid. 


\section{Types of functions being outsourced}

primary:

- "Full" - provision of services / implementation of state functions

- "Partial" - outsourcing of administrative processes auxiliary:

- "blue collar" - maintenance \& trades functions

- "white collar" - IT-services, financial and accounting services, expertise \& consultancy

Concluding the revision of the major theoretical and methodological premises of

the outsourcing techniques, we may outline the major principles that were put forth by the reformers, when they included this NPM technique into the list of reformatory measures. First of all, the methodological approach, adopted by the reformers, outline two major forms of outsourcing: outsourcing of state functions and outsourcing of auxiliary tasks related to ensuring the proper fulfilment of duties by the state institutions.

Secondly, while referring to outsourcing of state functions, Russian reformers emphasized 'partial' outsourcing (or the so-called outsourcing of the administrative processes) over outsourcing of entire state functions. While, in theory, a particular governmental function - such as the issuance of driver's licences-could be fully transferred to a private organization that starts acting on behalf of the state institution, outsourcing of administrative processes, instead means that only particular stepsnecessary for fulfillment of state functions - are being outsourced to private contractors. For example, preparation of the documents for obtaining a permit may be performed by a private organization, leaving the state institution with the sole function of granting the applicant with the permit or refusing the appeal. Preference for partial outsourcing, on the one hand, can be explained by the fact that outsourcing as a form of administrative practices was a complete innovation for the Russian system of government, furthermore reducing the state's control over its entire functions could be considered too risky. On the other hand, although the plan of the reform was rather ambitious, its implementation was 
expected to face substantial traction due to the nature of bureaucratic and administrative processes. In this regard, leaving as much control in the hands of the reformers was perceived as very important.

It can be argued that unlike performance management and especially state procurement, the reformers' approach to outsourcing remained declarative. The given measures did not put pressure on public institutions to actively implement various outsourcing technologies. This was one of the rare instances of the entire reform of public administration in Russia when regional authorities were advancing in utilization of procurement faster and deeper than federal institutions.

It was planned that reform measures aimed at the introduction of outsourcing to Russian administrative practices would be implemented in three stages between 2006 and 2008 (which was the first half of the extended second phase of the reform). The stages included: 1) the development of principles and technologies of outsourcing administrative processes (first half of 2006); 2) conducting experiments and pilot projects (second half of 2006); 3) the instalment of the developed principles and technologies of outsourcing administrative processes in federal administrative bodies (2007-2008).

Taking into account the level of conceptual elaboration, it can be stated that outsourcing was not developed to a substantial level. The given analysis reveals that outsourcing was prepared conceptually, but not processually. Major efforts of experts were made in the sphere of clarification and stratification of forms and types of outsourcing. At the same time, issues of implementation of outsourcing techniques remained underrepresented. 
Throughout the reform process, no attempts to systematically analyze the practices of utilizing outsourcing by government organizations in Russia were undertaken. The major massive of analytical information related to outsourcing refers to stages of development of the reform and includes normative and declarative characteristics. This chapter will consider several specific cases of how outsourcing was used by government organizations.

One particular case of outsourcing attracted most the media attention. It refers to the reform of the Russian military forces in 2008-2010 under ex-minister of defense Anatoly Serdyukov. It was argued that auxiliary functions that do not directly relate to the fulfilment by enlisted personnel of their direct responsibilities should be transferred to civilian organizations that would perform them on a contractual basis. Many auxiliary functions that were formerly executed by military personnel - such as maintenance of military vehicles, buildings and infrastructure, as well as catering, cleaning, medical, housing and communal services - were transferred to civilian contractors. The introduction of outsourcing of auxiliary functions was explained by the need to reduce public expenditures on the military sphere without diminishing the defensive capacity of military forces, as well as to adjust the Russian army to contemporary conditions. It was argued that the sole goal of military personnel should be the improvement of defensive capacity of the troops. As a result of recent changes, such as shortening of the conscription to one year, and a reduction of rank-and-file military personnel, it was argued, that military service implies acquiring combat skills and not conducting maintenance of quarters and equipment. 
In order to manage these processes a joint stock venture (JSC) "Oboronservis" was established in 2008. The organization is owned by the Russian Federation and controlled by the Ministry of Defense. It administers nine major sub-holdings that perform activities in specific economic spheres on behalf of the Ministry of Defense. Thus, JSC "Agroprom" is responsible for procurement of the military personnel with food supplies; JSC “Aviaremont" and JSC "Rosremvooruzheniie" conduct maintenance of aircrafts, as well as ground vehicles and equipment respectively. Another sub-holding - JSC "Slavianka" - is responsible for housing and communal services of military territories and buildings.

It was expected that involvement of contractual relations in the execution of auxiliary functions on behalf of the Ministry of Defense would improve quality of these services and reduce costs. Practical implementation, however, revealed the opposite. JSC "Slavianka" was mentioned recently in various media in connection with an investigation of corruption in the Ministry of Defense. Its ex-director - Aleksandr Yel'kin - was arrested and accused of fraud and commercial bribery. Since its establishment JSC "Slavyanka" has become the major contractor of the Ministry of Defense, performing maintenance and communal services for military facilities. As one expert pointed out, this organization was not only incapable of improving the situation; its activities resulted in "multiple emergency situations that led to serious and, in some cases, extreme consequences. ${ }^{.93}$ Performing its duties this organization violated the federal legislation multiple times. For example, it increased communal tariffs for its customers more than

\footnotetext{
${ }^{93}$ Vasilii Vorob'ev (November 21, 2012) "Autsorsing bez prikras" Voennopromyshlennyi kurier. No.46 (463)
} 
one time a year although the law No. 210-FZ from December 30, 2004 "On the fundamentals of regulations of tariffs of communal complex organizations" forbids this.

Apart from issues of corruption and violation of the legislation, the model of outsourcing that was created by the Ministry of Defense had important systemic deficiencies. The most important among them was deliberate avoidance of open competition among multiple private organizations. There were a series of governmental resolutions that made JSC "Slavianka" the sole contractor for the Ministry of Defense in various spheres of economic activity. ${ }^{94}$ The situation was repeated in the cases of other sub-holdings of JSC "Oboronservis". 95 At the same time, as the expert reveals, in the majority of cases these sub-holdings were involving other subcontractors who were making actual delivery of goods and services. The created scheme established the function of JSC "Oboronservis" and its direct subsidiaries as mediators, whereas actual work was conducted on a largely uncompetitive basis. All this resulted in unnecessary growth of budgetary funds due to the inefficiency of the developed system of outsourcing.

\footnotetext{
${ }^{94}$ For example, Resolution No.645-r from April 15, 2011 determined JSC "Slavianka" the exclusive supplier of cold water and sewerage services for Ministry of Defense. Resolution No.1074-r from June 29, 2011

95 See: Vasilii Vorob'ev (November 21, 2012) "Autsorsing bez prikras" Voennopromyshlennyi kur'er. No.46 (463)
} 
Figure 5. Efficiency of outsourcing in the Ministry of Defense. ${ }^{96}$

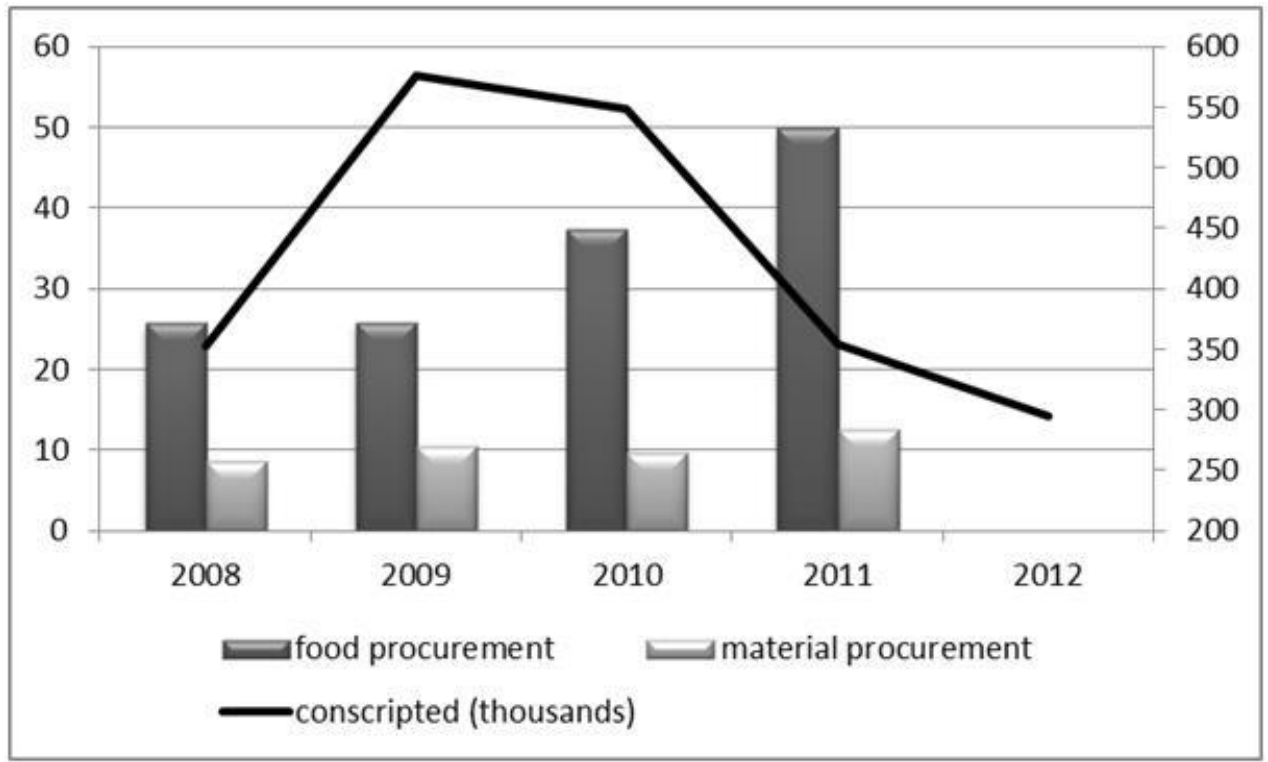

Figure 5 illustrates changes in patterns of expenditure made by the Ministry of Defense after the introduction of the system of outsourcing. Three parameters were chosen for analysis: expenditures on food and material procurement that were outsourced to the sub-holdings of the Ministry of Defense. This data is presented against the annual quantity of conscripted personnel. The validity of such representation is supported by the fact that the needs of conscripted soldiers must be fully supported by the state during their time of service. This includes supplies of uniform, ammunition, food supplies etc. Reduction of the quantity of conscripted soldiers must result in a reduction of expenses on the given categories. At the same time, the chart reveals the opposite. Other instances, that include substantial curtailment of enlisted military personnel (from more than 350

${ }^{96}$ Figure 5 is prepared by the author on the basis of official statistics, presented by the Ministry of Finance and Ministry of Defence. The budgetary expenses are calculated on the basis of data presented in the annual Budgets of the Russian Federation. Online at http://info.minfin.ru/kons_rash_isp.php (accessed: December 10, 2013) The quantity of conscripted military personnel is taken from the official statistics, as it is presented on the internet portal of the Ministry of Defence at URL: http://mil.ru/ (accessed: December 10, 2013). The left vertical axis indicates the budgetary expenditures in billions of roubles; the right axis indicates the quantity of conscripted military personnel. 
thousand to less than 150 thousand) and known corruption scandals do not allow hypothesizing that an increase in expenses on food and material provision was due to improvement of its quality. ${ }^{97}$

The first experience of large scale outsourcing received critical responses from the political establishment. Vladimir Putin admitted that although "it is a quite efficient system... its instalment is linked with definite problems and shortcomings." 98 Current minister of defense Sergei Shoigu argued that the 2008 system of outsourcing did not meet expectations, although the idea to transfer to private contractors some auxiliary functions was a good idea. ${ }^{99}$

There is another case that reveals problems of a different sort. A private limited liability company "Schet Spets Trans" provides transportation services for multiple public institutions, such as the State Duma, the Accountants' Chamber, Gazprom etc. In 2011 this organization won three consecutive tenders on supplying the State Duma with automobiles and drivers for the needs of the deputies and personnel. The total cost of three-year contracts was 3,8 billion rubles (appr. US $\$ 130$ million). Signing of the first contract did not result in a reduction of its cost, as far as no competitors participated in the tender. ${ }^{100}$ The second tender resulted in $1,5 \%$ reduction of the cost of the final

${ }^{97}$ Vasilii Vorobiov op.cit. reveals cases when the quality of purchased food products was inappropriate.

${ }^{98}$ Sergei Smirnov (December 6, 2012) "Autsorsing, vyiti iz stroia” Gazeta.ru, Online at: http://www.gazeta.ru/politics/2012/12/06_a_4881205.shtml. Accessed, September 10, 2013.

99 "Shoigu: Sistema autsorsinga v Minoborony ne opravdala ozhidanii" (June 13, 2013) Vzgliad, Online at: http://vz.ru/news/2013/6/13/637051.html Accessed, September 10, 2013.

${ }^{100}$ All information regarding the tender is available online at: http://zakupki.gov.ru/pgz/public/action/orders/info/common_info/show?notificationId=2 111152 Accessed: September 10, 2013 
contract, perhaps, due to participation of a second contender. ${ }^{101}$ In the final tender there were three participants, resulting in a reduction of $15,5 \%$ during the auction. ${ }^{102}$ Although, all procedural formalities were met, this form of outsourcing cannot be considered successful. The customer was unsatisfied with the quality of provided services and demanded improvement. ${ }^{103}$ Moreover, the company previously had difficulties fulfilling their obligations, so its selection may be explained partially by imperfection of regulations in the sphere of outsourcing. ${ }^{104}$ Moreover, the very idea to put this type of service on outsourcing can be questioned. Analysis reveals that the costs of the contract meet the average standards for renting prestige automobiles in Moscow. For a public institution that utilizes such services on a daily basis, transferring the services at rental prices cannot be considered efficient.

Although outsourcing might have discredited itself in the case of large-scale military processes, it proved to be quite efficient with respect to IT-services. A discussion of outsourcing must include two factors at the very beginning. First of all, the design of reform in Russia was aimed at bringing the national bureaucracy and public institutions infrastructure in concordance with contemporary managerial principles. This inevitably

${ }^{101}$ All information regarding the second tender is available online at: http://zakupki.gov.ru/pgz/public/action/orders/info/common_info/show?notificationId=2 111981 Accessed: September 10, 2013

${ }^{102}$ All information regarding the second tender is available online at: http://zakupki.gov.ru/pgz/public/action/orders/info/commission_work_result/show?notifi cationId=2112228 Accessed: September 10, 2013

${ }^{103}$ Petr Kozlov (August 27, 2012) "Deputaty nedovol'ny svoim sluzhebnym transportom" Izvestia. Online: http://izvestia.ru/news/533804 Accessed: September 10, 2013

${ }^{104}$ In 2009 employers of "Schet Spets Trans" went on strike accusing the company in violation of the labor legislation. For more details refer to: Olesia Gerasimenko et al. (October 21, 2009) "Voditeli deputatov ostanovilis' s trebovaniiami" Gazeta.ru. Online at: http://www.gazeta.ru/social/2009/10/21/3275586.shtml Accessed: September 10, 2013 
implied addressing issues of the development of post-industrial informational society. For governance, this meant adopting the principles and technologies of e-government. The second issue related to the conditions of IT development in the public and private sectors. It was obvious that years of stagnation and underfunding left the pre-reformed public administration without experienced personnel, capable of conducting IT-based modernization projects to a satisfactory level. The establishment of such a cluster of public employees would include lengthy "headhunting", costly training programs, and the need for remuneration expectations of these employees at the level that suits their expectations and competes with similar salaries in the private sector.

However, the volume of work, as well as the given time frame established by the federal targeted program "Electronic Russia", demanded immediate action. In such circumstances outsourcing of IT-functions appeared to be an almost inevitable option. The general task of the establishment of efficient infrastructure of e-government demanded state institutions to meet the prescribed standards of openness and information accessibility. In many cases that involved qualitative redevelopment of the institution's informational infrastructure. The tasks involved not only the introduction of modern and convenient internet portals, but also implementation of large-scale projects in the sphere of automation and standardization of administrative processes. These works could not be performed within the framework of state procurement and demanded the establishment of long-term relationships between contractors and customers, as the former would not only "deliver" the product, but also ensure its subsequent maintenance.

Experts in the sphere of information technologies mentioned the substantial growth of attention of state institutions to the IT sphere almost immediately after the 
beginning of the reform of public administration. In the first years after the inception of the reform "expenses on IT-projects of the state institutions of all levels grew faster than the entire IT market." 105

Since inception governmental outsourcing projects account for 25-30 percent of the entire sector (of outsourcing services), being one of the most important contributors to its growth. Efficiency of partnership in this sphere was also noticed internationally. In the 2012 United Nations E-Government Survey experts evaluated rapid progress in the sphere of governmental information technologies, saying that "[a]dvancing 32 positions in the world rankings, the Russian Federation (0.7345) became the leader in Eastern Europe." ${ }^{106}$ Moving from 59th to 27th place (out of 190) in the world ranking of countries with the most advanced e-government infrastructure, Russia was placed 7th in the list of emerging leaders in e-government development. ${ }^{107}$

${ }^{105}$ Sergei Shalmanov (2006) "Zatraty na informatizatsiiu: novyi rost”. CNews. (On-line) [URL: http://www.cnews.ru/reviews/free/gov2006/articles/expenses.shtml]. Accessed: September 10, 2013.

${ }^{106}$ United Nations E-Government Survey 2012: E-Government for the People. New York, p.30

${ }^{107}$ Ibid., p. 12 
Figure 6. United Nations E-governance Index Trend for the Russian Federation ${ }^{108}$

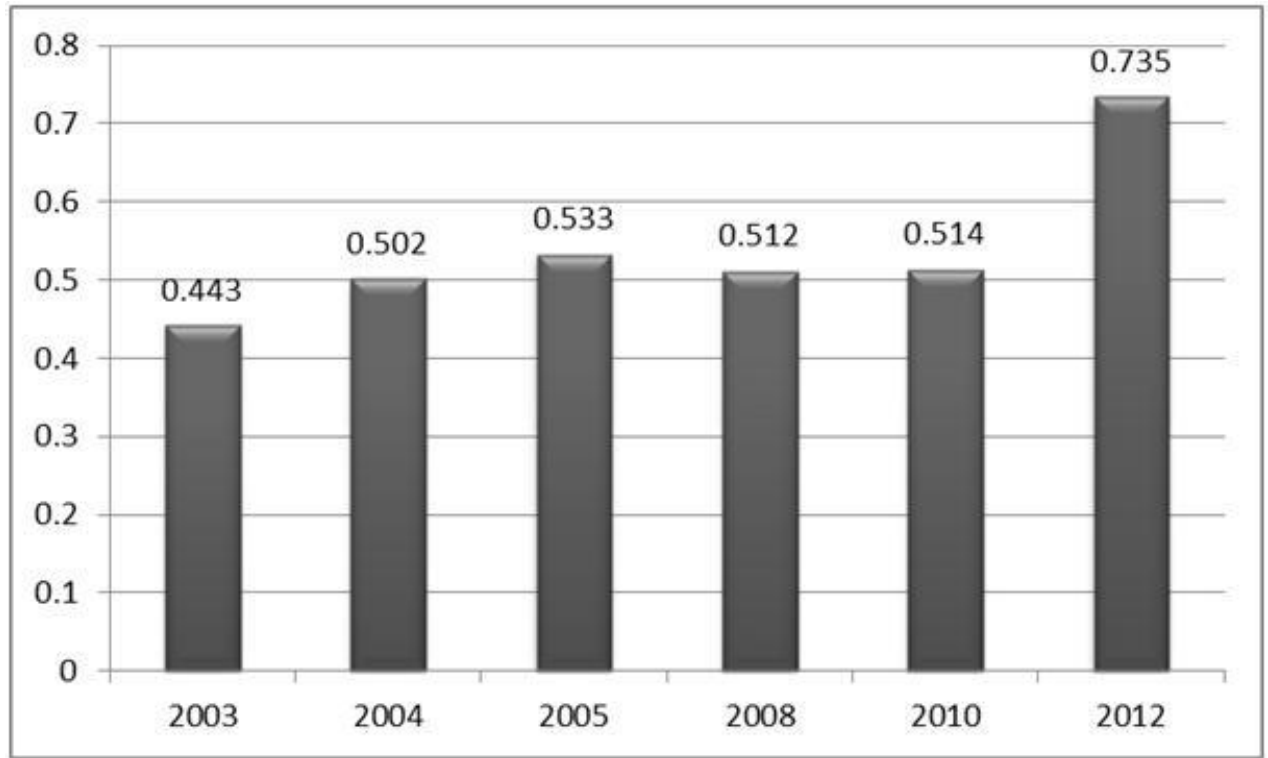

The fact that outsourcing dominated in the sphere of governmental IT-functions signifies the relative efficiency of this administrative technology in comparison with other sectors of government. Therefore, it seems important to reveal factors that led to such impressive advancement. First of all, the development of information technologies was given a definitive infrastructure and legal framework. The federal targeted program determined not only the normative aspects of the forthcoming modernization, but also detailed steps and procedures. Later developments specified the reform measures. Thus, in 2010, federal law No.210-FZ "On the organization [of the process] of provision of state and municipal services" prohibited all public agencies from requesting additional documents from citizens if this information could be obtained by the agencies themselves. This regulation inspired the development of a unified automated

${ }^{108}$ Figure 6 was prepared on the basis of data, provided by the United Nations EGovernment Development Database, Russian sub-sample. Online at: http://unpan3.un.org/egovkb/ProfileCountry.aspx?ID=141 (Accessed: December 10, 2013). 
administrative system that would facilitate the document circulation between various departments within the system of government.

There was also articulated political support. Vladimir Putin, then the primeminister of Russia, himself patronized the introduction of the new system. He also established that July 1, 2012 would be the deadline, when regional and municipal agencies should convert to "electronic inter-departmental interactions." 109 Obvious political interest in the reform in this sphere yielded positive results. Attention to the reform at the very top of the power vertical was supplemented by a peculiar situation in the market of IT-services. As it was stated elsewhere "all large providers of [IT] services take care of their reputation," because it takes "many years to earn it." ${ }^{110}$ In such circumstances private contractors show their interest to meet customers' requirements. Moreover, continuity of the program and the involvement of private contractors in it from the beginning allowed the establishment of a mutual learning process by means of a productive dialogue between the customers and suppliers.

At the local level, outsourcing was used more vigorously. For example, several municipalities made a decision to transfer supply and maintenance of ambulance vehicles to private contractors. This measure was aimed at reducing the administrative burden on heads of ambulance services and operational costs. The system was introduced in the municipalities of Perm, Kirov, Ufa, Volgograd and Yekaterinburg. Two latter cases

\footnotetext{
109 "Stenogramma otcheta Vladimira Putina v Gosdume" (April 11, 2012) Rossiiskaia gazeta. (Online) [URL: http://www.rg.ru/2012/04/11/putin-duma.html]. Accessed, September 11, 2013.

${ }^{110}$ Maksim Nikitin (2008) "Osnovnye kriterii vybora autsorsingovogo partnera" Cnews. (Online) [URL: http://www.cnews.ru/reviews/free/gov2008/articles/15_02_choosepartner.shtml]. Accessed, September 11, 2013.
} 
already revealed the insufficiency of the system as the projects were rescinded ${ }^{111}$ But in other instances, the system was established and currently functions. The relative popularity of outsourcing at the local level, in comparison with the federal institutions, posits an important question on the nature of decision making in the post-reform system of governance. It is obvious that at the grassroots level, the strength of the power vertical is lower. Municipal authorities also face the scarcity of available budgetary funds that are mostly transferred from federal and regional levels.

Concluding the review of the cases of implementation of outsourcing techniques, it can be argued that so far, the transfer of state functions to private contractors does not lead to desired outcomes. In some instances, like in the case of Ministry of Defense, outsourcing mutated to a large-scale scheme of corruption; in other cases it is not possible to speak of substantial improvement in quality of function implementation and a substantial reduction of budgetary spending. Relative success stories, such as outsourcing in the IT-sphere, suggest that the existence of two factors - the demand to build a modern IT-infrastructure, reinforced by a specialized federal targeted program, as well as obvious inability of public institutions to perform this job by themselves - contributed to the efficiency of this administrative technology. At the same time, contractors point out the inefficiency of the approach that public agencies adhere to in performing outsourcing. Outsourcing is relatively more popular at the municipal, than at the regional and federal levels. This can be explained by actual scarcity of budgetary funding at this level and

\footnotetext{
${ }^{111}$ Vladimir Nazarov (March 1, 2013) "Vnedriat' autsorsing “Skoroi pomoshchi” nuzhno s umom", Vedomosti. Online at: http://www.vedomosti.ru/opinion/news/9638481/autsorsing_yad_ili_panaceya
} 
difficulties in attracting additional funds. However, the need to meet budgetary limits may result in a substantial reduction of the quality of outsourced processes.

A comparison of the positive and negative connotations of outsourcing allows one to reach a conclusion that the utilization of this technique depends directly on the existence of two critical factors. The first is a well-established and self-sufficient private industry - in the particular sphere that is being outsourced-which is able to independently, and with sufficient quality, perform the task which is being outsourced. The second is the freedom of government managers from operational dependence on the rigid framework of the power vertical—which implies an existence of a government culture that promotes initiative and flexibility. It seems like, at least in the Russian case, this would be the most favourable circumstance for the reformers to make a decision on whether to use outsourcing, especially if it is an outsourcing of a state function or a particular administrative process.

Yet the reformers did not pay much attention to the measure. As far as they adopted a technocratic approach to the entire reform of public administration, they described outsourcing in their program documents and proposed some steps for its implementation. However, during the second stage of the reform, the major focus was on other aspects, and due to the fact that conducting the reform was largely enforced from the top, outsourcing was not introduced systematically, regardless of the methodological recommendations of experts. Instead, decisions on whether or not to utilize this option have been largely transfered to the discretion of the management of public institutions. Moreover, outsourcing has not received systematic attention from the reformers. Regardless of prepared recommendations, a decision was not made regarding the 
approach to the implementation of outsourcing techniques. Nor was a specific legislation prepared that would introduce outsourcing as a legal term.

\section{Conclusion}

This chapter discussed three reform initiatives, that, more than any other measures, are driven by the ideology of New Public Management. On many accounts, these very measures determined the major discourse of the entire dissertation - that is on the applicability of New Public Management reform tools to the Russian case. Although these three aspects of the reform were quite distinct from other reform measures, they were apprehended by the reformers and included into the conception of the reform, not as declarations, but rather like a carefully selected agenda of reform measures.

Of all three measures - performance management, public procurement, and outsourcing - the former one was the most quintessentially managerial. Yet, the way it was addressed in practice in Russia differed substantially from not only contemporary theoretical discussions, but also from its successful practical implementations. Russian reformers overemphasized strategic mid-term planning and completely ignored two other aspects of performance improvement, namely operational freedom for public officials and the reassurance of democratic accountability. These two fundamental factors, on the one hand, provide public officials with incentives to do their work more efficiently, and, on the other hand, keep them aware of what the public value is today. Without them, strategic planning is at greater risk to mutate into pointless activity.

At the same time public procurement has become the most efficiently used NPM-oriented reform measure. It operated within a particular technical and legal infrastructure. Implementing the reform, reformers tried to place the major focus of the 
entire system on price reduction. It was assumed that as a the matter of accuracy, technocratic and holistic, or "one size fits all" approach to procurement would be the most beneficial. Yet it resulted in multiple failures, corruption and subsequent transformation of the normative-legal framework.

Outsourcing, on the other hand, was not given such detailed attention. Instead of adopting one of three possible alternatives to outsourcing - clustered, centered or decentralized - reformers left the choice to the user's discretion. As a result of this decision, in this sphere occurred perhaps the most vocal scandal that signified the inappropriateness of managerial technologies for the Russian case of reform. 


\section{Conclusion}

This dissertation has been dedicated to an analysis of the reform process of the system of government in the Russian Federation, which formally began in 2003 and continues to this day. The difficulties of the task were recognized by the reformers themselves, as well as the critics of the proposed reform. In addition, the continuous postponement of such an urgently needed reform during the first post-Soviet decade implicitly supports the argument about the complexity of the object of the reform. The political decision to implement this reform was reached during a relatively favorable economic period for the country, and indeed during a positive dynamic in the global economy as a whole. Stable growth in the prices of fossil fuels- the most important part of Russian exports - provided the country with a budget surplus, as well as with a solution to more urgent problems in the social sphere. Furthermore, economic growth in the country confirmed that an inflexible and weakly organized government apparatus acts as the main impediment in the path of further development of the country. Hence, the necessity for a solution to the problems evident in the sphere of public administration became inescapable.

Furthermore, it was necessary to bring the bureaucratic system into alignment with the new architecture of the political sphere that was proposed and implemented by President Putin in the first years of his rule. The reinforcement of the 'power vertical', the restoration of the political-administrative unity, and the considerable changes in the socio-political space - all of these factors created new tasks for the civil service, necessitating a modernization of its institutions and an implementation of new technologies of administration. Yet, the reform has not yet resulted in the substantial 
improvement of quality of public administration and, therefore, its ability to conduct efficiently other socio-economic reforms.

Analyzing factors that contributed to the reform failures this dissertation hypothesized that the major reason for them could be the conceptual inconsistency between the reform's ideological background, on the one hand, and the mainstream political process that is based on the doctrine of the 'power vertical'. The stated hypothesis demanded not only conducting research in the area of public policy and civil service, but also taking a broader perspective and assessing the conceptual milieu in which the reform of public administration and other political reforms were conducted. The dissertation focused on the process of implementation of ideationally-driven reform projects in order to analyze their congruence, as well as emerging discrepancies. The primary objective of this endeavor was the assessment of whether these discrepancies were driven by the conceptual incapability of these projects.

Chapter 1 presents a modern architecture of political power and political relationships in the country in the in the form of the 'conceptual pyramid', the logic and dynamic of the political process which subordinates models of the power vertical. This approach places public administration in the centre of the pyramid. In this way it ties together political processes of the highest order in the reform of federal relationships; political, electoral, and other reforms; and grass-roots political processes at the local level. With the incorporation of regional blocks into the power vertical, public administration obtained additional functions of translation of government policy, as determined by the centre. On top of this, the effectiveness of the government apparatus influences how socio-economic reforms are carried out, as well as the provision of 
government services at the necessary level. In this way, by being put at the epicenter of the country's political development, the reform of the civil service becomes a central binding factor, affecting successful implementation of measures on which depend Russia's future growth.

To solve the raised issues, the country's administrators made the decision to implement the reform, based on a qualitatively different conceptual platform. The necessity to avoid the mistakes, specifically ones made in reform attempts during the first post-Soviet decade, was stressed, most notably blind mechanical copying of developed Western technologies. To develop the conceptual framework and prepare the reform program, government officials as well as representatives of academic and working circles, were engaged. After considerable reflection, the New Public Management model was chosen as a basis of the reform.

During the last decade, NPM as a reform model of public service undertook a paradigmatic status. Almost every country that have legislated a reorganization of their government apparatuses has to one degree or another, resorted to the ideology and tools of NPM. At the heart of the paradigm lies the idea of borrowing and adapting management processes that were developed and successfully implemented in the private sector, for use in the public sector.

At the same time, Russian reformers understood that a plain transplant of established Western models would not lead to the planned results. Moreover, international specialists conducting comparative analyses of the reform of administrative systems in different countries — analyses ordered by Russia — reached the conclusion that the various countries - depending on the peculiarities of their constitutional systems, 
political-administrative culture, and also various levels of socio-economic development — demonstrated varying levels of traction to the reform.

With the goal of adapting the reforms to the actualities of the Russian political process, and similarly to the peculiarities of the executive systems - some of which were inherited from the Soviet system-considerable changes were made to the reform. Firstly, a decision was made to emphasize the institutional aspect, most notably to begin the reform with the introduction of new three-tier system of government institutions based on the ministry-service-agency hierarchy. Secondly, with the goal of optimizing the existing system of public service, measures were included that strengthened the supervision and organization of the internal services, which, at least at the conceptual level, contradicted the principles of NPM. Thirdly, at the early stages of the reform, a decision was made to separate the administrative reform and the reform of the public service (the bureaucracy). These factors resulted in the uniqueness of the Russian project of administrative reform, and its difference from analogous reforms conducted in other countries.

The reform turned out to be a considerably difficult process, including with it a restructuring of many contiguous issues of control of socio-economic processes in the country. Suffice it to say that on the success of the reform of the state apparatus depended the successful implementation of reforms in economic and social spheres. At the same time, the reform itself demanded a practical readjustment of the principles and philosophy of conducting public services. The situation was further complicated by the presence, well established since Soviet times, of quite inefficient administrative practices. A factor of no small importance, which appeared during the reform process, became the 
methodological peculiarity of the reform. In other words, the administrative reform can be explained through the factual union of the subject and object of the reform. The state apparatus has to reform itself. This factor undoubtedly adjusted the path of the reform process.

In the decade that followed its initiation in 2003, the reform underwent three consecutive stages. Simultaneously measures were conducted, aimed at modernizing the public service. In addition to the aforementioned three-tier system of federal institutions, an analysis of government functions was also undertaken for the purpose of optimizing them and eliminating excessive regulation; a series of measures were undertaken to standardize and regulate the remaining state functions; and management technologies of e-government were implemented. Similarly, the reformers paid special attention to measures being created within the paradigm of NPM; in particular, there was an attempt to implement technologies of performance management, outsourcing, and a system of government procurement.

On the whole, assessing the decade-long reform, a conclusion can be reached that the reform did not achieve its proposed goals. This thesis is also held by experts who were interviewed during the course of this dissertation research. Apart from experts' appraisals, the failure of the reform is similarly evident from objective facts. In particular, in the 2005 Conception of the Administrative reform during 2006-10, the reformers showed that they planned to achieve a substantial improvement of Russia's position in internationally recognized governance ratings. However, as the analysis conducted in Chapters 4 and 5 shows that not one of the indicated levels was reached, and indeed it is impossible to assert that any indicator was substantially improved, whereas several 
indicators - such as the level of corruption—even deteriorated as a consequence of the reform. Thus the reform has produced quite ambiguous results and cannot be deemed successful.

The causes of the failures have become the object of the detailed analysis of this dissertation. Amongst the most obvious reasons for the failure of the reform are corruption, weak institutional discipline, and a low professional ethics of civil servants. The state apparatus is also criticized for being too cumbersome, having overbureaucratized administrative procedures, and the poor quality of provided public services. All these observations are made against the background of considerable budgetary expenditures not only on the implementation of the reform, but also on the state apparatus itself. As Chapter 6 shows, on many occasions the increased funding was used not on measures aimed at improvement of the quality and efficiency of public institutions, but rather on improvement of personal well-being of the top-tier of public officials. There were revealed cases not only of corruption and misappropriation of public funds, but also of undesignated budgetary spending.

At the same time, this dissertation research undertook an attempt to answer the question of why such a well planned and prepared reform did not succeed. It is completely evident that the reformers, while planning the reform, had to take account of corruption and other negative pathologies of the public administration in the country. Thus the main hypothesis of this dissertation was directed at the more fundamental phenomena, specifically the discrepancy between the philosophy and ideology of the reform and the main trend in the Russian political process. The failure of the reform is explained in the dissertation through the conceptual mismatch between the managerial 
paradigm of public administration - directed towards the development of horizontal and cross-institutional ties-and a paradigm of the 'power vertical'-emphasizing the development of vertical ("top-down") ties. This dissertation argues that reform of the system of public administration on the basis of NPM necessitates decentralization and a weakening of the classic form of beauracratic control.

The difficulty, encountered even at the early stages of the execution of the reform raise a whole series of questions relating to the conformity of the goals and the objectives of the reform on the one hand, and the chosen methods of implementing and realizing the reform on the other. The primary question relates to the justification of the chosen reform model. As a point of fact, NPM is currently the most commonly utilized theoretical and methodological approach to reforming public administrations. At the same time, alternative theories and approaches were also developed. Other countries, particularly China, are conducting a reorganization of their government institutions based on these unique models. Despite the fact that the choice of the basic ideology as the concept of shrinking government has been justified by the currently dominant trend, the adequacy of the whole model can be subject to uncertainty.

The reform process is analyzed in detail in the fourth chapter, one of the hypotheses of which asserts that the process itself might have been a factor that contributed to the difficulties of the reform. Firstly, this is tied to the subject-object contradictions that lie at the heart of the public service reform. The fact that the state is obliged to reform itself inevitably contributes to the manifestations of incrementalism in implimenting reformatory measures. During the research process, several key moments were revealed. Firstly, despite the successful implementation of the three-tier system of 
public administration and an institutional division of the three main types of government functions - formation of government policy, control and oversight, and provision of public services and management of government property — the main task, particularly the formation of government institution, relatively independent from each other, was not achieved. Moreover, the fact that the three-tier system was introductioned by a Presidential decree and not legislated, confirms the relative ephemerality of this innovation. On top of this, as the analysis asserts, the very structure of government institutions proved itself quite unstable and most of the institutions of government power were subject to either transformation or eliminated. Secondly, the main principle of separating political and administrative functions - the central basis of almost all pracitacal implementations of NPM models-was not achieved. As a result of the reform, the ministries retained not only political and administrative, but also budgetary control over their subordinated services and agencies, thus transforming themselves into a certain type of 'micro-paradigm', resembling the main conceptual model of the 'vertical of power'. Thirdly, the conducted research revealed the relative success and fulfillment of reform measures related to the optimization of government functions and the implementation of technologies of e-government. At the same time, reform measures based on the ideology of managerialism were substantially less successful, and spawned numerous deviations from the original plan. This circumstance leads to an implicit assertion of paradigmal inconsistency of the concepts of 'power vertical' and NPM, as well as the domination of the first reform paradigm over the second.

The inconsistency of the reform's results in both the initial conception and the paradigm of NPM allowed for a more detailed analysis of the practices of applying 
managerial methods of administration. The sixth concluding chapter was dedicated to this analysis. The chapter took as a basis the three most evident elements of the reform: performance management, state and public procurement, and outsouring of state functions. Detailed analysis of each of these elements revealed the existence of deviations from the ideal and typical model in the application of these three technologies. As a result, the chosen methods contributed to the growth of the level of corruption, the decline of quality control, and this also did not lead to a significant decline in budgetary expenditures, which had been a planned outcome.

It is impossible, however, to ignore the miscalculations made during the creation of the theoretical model of reform. As was noted in the dissertation, at the intial stages of the reform, political circles were divided into three main ideologically different groups: the 'siloviki', the 'liberals' and centrist-technocrats. The latter, with Dimitry Kozak leading them, were in charge of developing the concepts and the methodology of the reform. The technocratic approach to reforming the state appartatus, in an attempt to reconcile rival ideologies, introduced considerable characteristics to the reform project, which in the end did not lead to the planned results. On the contrary, in the sphere of NPM-technologies, the technocratic approach only strengthened the negative tendencies, and led to a disbalance of the system, when the focus on the result and the predetermined operational freedom were not supplemented by effective mechanisms of social control.

Therefore, this dissertation began from hypothesizing that the major reason for the failure of the reform was conceptual inconsistency between the reform design and the nature of political process in Russia. Several aspects of the reform-its ideology, its process and three most crucial reform measures - were investigated thoroughly for the 
purposes of assessment of validity of such assumption. It seems that each analyzed aspect contributed to demonsrating that the working hypothesis was the correct explanation of the nature of the reform's difficulties. The choice of New Public Management as an underlying ideology of the reform was justified by its popularity among the reformers all around the world. Yet, the approach could not be borrowed without substantial modifications. Therefore, developing the conception of the reform in Russia reformers created a sort of hybrid design. Obviously, these changes not only influenced the process of reform; they also had an impact on its outcomes. The process of reform itself was a substantial factor due to the nature of the institute of public administration that is doomed to reform itself. And the process also influenced outcomes, directly addressing the causes of failure to the accountability issues. Public officials did not become accountable to the citizens as consumers of public services, as NPM model suggests, due to prevalence of the top-down hierarchy and lack of vigilance and oversight of day-to-day practices of public officials by their superiors. Three investigated cases of reforms-performance management, public procurement, and outsourcing — revealed the detrimental effects that the conceptual conflict has on efficiency of public service in the country. As a result, at the end of the current third stage of the reform, the trends are ever evident, and are directed towards a strengthening of the regulation and supervision of the activities of public servants.

Besides the main argument the research also revealed the technocratic nature of the public administration reform in Russia that also contributed to the reform's failures. Such characteristics manifested themselves more evidently in case of the three NPMbased innovations that were proposed in the reform's 2005 Conception. They installed a 
legal-institutional framework that resembled major values of the NPM approach, such as managerial freedom and performance accountability. Technocraticism of this approach revealed itself in the fact that constructing an ideal-type framework, they, deliberately or not, overlooked the fact that public institutions can take advantage of the system and contribute to its inefficiency, while pursuing their own or corporate objectives. In other words, the reformers followed the current trend and implemented the reforms as they theoretically should be implemented without taking into account the specificity of the political process in Russia.

Thus, the dissertation established a particular pattern of research of contemporary political reforms in Russia. Experiencing a sunset of its popularity, NPM ideology also loses significance in the context of the Russian reform. However, the uniqueness of the Russian project, and similarly the evident dominance of the 'power vertical', leads to an assertion that the future development of the government apparatus will go on contrary to the latest theoretical developments in the sphere of public administration. 


\section{Bibliography}

\section{Legal documents:}

Constitution of the Russian Federation, 1993 issue

Federal Law No. 192-FZ from December 5, 1995 on "O printsipakh organizatsii Soveta Federatsii Federal'nogo Sobraniia Rossiiskoi Federatsii”

Federal Law No. 184-FZ of October 6, 1999. “Ob obshchikh printsipakh organizatsii zakonodatel'nykh (predstavitelnykh) i ispolnitelnykh organov gosudarstvennoi vlasti sub"ektov Rossiiskoi Federatsii."

Federal Law No. 184-FZ "Ob obshchikh printsipakh organizatsii zakonodatelnykh (predstavitelnykh) i ispolnitelnykh organov gosudarstvennoi vlasti sub"ektov Rossiiskoi Federatsii.” October 6, 1999. Federal Law No. 113-FZ from August 8, 2000 on “O printsipakh organizatsii Soveta Federatsii Federal'nogo Sobraniia Rossiiskoi Federatsii”

Federal Law No. 849 from May 13, 2000 “On the Plenipotentiary representative of the President of Russian Federation in the Federal District”.

Federal Law No. 58-FZ, of May 27, 2003 “O sisteme gosudarstvennoi sluzhby Rossiiskoi Federatsii.”

Federal Law No. 21-FZ of February 14, 2007 "O vnesenii izmenenii v otdelnye zakonodatelnye akty Rossiiskoi Federatsii v sviazi s izmeneniem poryadka formirovaniia Soveta Federatsii Federalnogo Sobraniia Rossiiskoi Federatsii"

Federal Law No. 189-FZ from July 21, 2007 “O vnesenii izmeneniia v statiu 1 federal'nogo zakona "O poriadke formirovaniya Soveta Federatsii Federalnogo Sobraniya Rossijskoj Federatsii" 
Decree of the President of the Russian Federation No. 1969 of October 3, 1994 "O merakh po ukrepleniiu edinoi sistemy ispolnitelnoi vlasti v Rossiiskoi Federatsii. Sobranie Zakonodatelstva Rossiiskoi Federatsii 1994 No.24.

Decree of the President of the Russian federation No. 774 of July 23, 1997 "O podgotovke upravlencheskikh kadrov dlia organizatsii narodnogo khoziaistva Rossiiskoi Federatsii"

Decree of the President of the Russian Federation No.1496-Pr from August 15, 2001. "Kontseptsiia reformirovaniia gosudarstvennoi sluzhby Rossiiskoi Federatsii." Decree of the President of the Russian Federation No.1336 of November 19, 2002 "O federal'noi programme reformirovaniia gosudarstvennoi sluzhby Rossiiskoi Federatsii (2003-2005)"

Decree of the President of the Russian Federation No. 824 of July 23, 2003 "O merakh po provedeniiu administrativnoi reformy v 2003 - 2004 godah"

Decree of the President of the Russian Federation No.1274 of September 24, 2007 "Voprosy struktury federal'nykh organov ispolnitel'noi vlasti"

Decree of the President of the Russian Federation No.261 of March 10, 2009 "O Federal'noi programme "Reformirovanie i razvitie sistemy gosudarstvennoi sluzhby Rossiiskoi Federatsii (2009-2013 gody)."

Decree of the President of the Russian Federation No. 1657 "Ob optimizatsii chislennosti federal'nykh gosudarstvennykh grazhdanskikh sluzhashchikh i rabotnikov federal'nykh gosudarstvennykh organov". 
Order of the President of the Russian Federation No. 176-rp from May 7, 1997 “O komissii po razrabotke proekta Programmy gosudarstvennogo stroitel'stva v Rossiiskoi Federatsii”.

Order of the President of Russia No. Pr-1496 from August 15, 2001 "Kontseptsiia reformirovaniia sistemy gosudarstvennoi sluzhby Rossiiskoi Federatsii”.

Resolution of the Government of the Russian Federation No. 550 of June 3, 1995. "O dopolnitel'nykh funktsiiakh Ministerstva Iustitsii Rossiiskoi Federatsii."

Resolution of the Government of the Russian Federation No.1222, from September 26, 1997 "O produktsii, zakupaemoi dlia gosudarstvennykh nuzhd bez provedeniia torgov (konkursov)."

Resolution of the Government of the Russian Federation from January 19, 2005 No. 30. “O Tipovom reglamente vzaimodeistviia federal'nykh organov ispolnitel'noi vlasti”.

Resolution of the Government of Russia No. 1789-p from October 25, 2005. “Kontseptsia administrativnoi reformy v Rossiiskoi Federatsii v 2006-2008 godakh"

Resolution of the Government No. 177 from March 24, 2007 "O podgotovke upravlencheskikh kadrov dlia organizatsii narodnogo hoziaistva Rossiiskoi Federatsii v 2007/08 - 2014/15 uchebnykh godakh."

Resolution of the Government of the Russian Federation No.1021-r of June 10, 2011. “Kontseptsiia snizheniia administrativnykh bar'erov i povysheniia dostupnosti gosudarstvennykh i munitsipal'nykh uslug na 2011 - 2013 gody." 


\section{Literature}

Afanas'ev, Mikhail (2009). “The Quality of the State—Russia's Chief Problem.” Russian Politics and Law, vol. 47, no. 4, pp. 58-72.

Allina-Pisano, Jessica (2010). "Social contracts and authoritarian projects in post-Soviet space: The use of administrative resource." Communist and Post-Communist Studies. Vol. 43, pp.373-382

Almond, Gabriel A.; Verba, Sidney. (1965). The Civic Culture. Boston, MA: Little, Brown and Company.

Ambrosio, Thomas (2009). Authoritarian Backlash: Russian Resistance to Democratization in the Former Soviet Union. Farnham: Ashgate. Analiz zarubezhnogo opyta formirovaniia rezerva upravlencheskikh kadrov gosudarstvennoi sluzhby. (2012) [Online]. (URL http://rezerv.gov.ru/GovService.aspx?id=691\&t=34) . (Accessed May 28, 2013).

Anderson, Perry (2007). "Russia's Managed Democracy.” London Review of Books. Vol.29 No.2., pp.3-12

Anderson, Richard D. Jr. (2010). "When the center can hold: The primacy of politics in shaping Russian democracy." Communist and Post-Communist Studies. Vol. 43, pp. $397-408$

Andrews, Christina W.; de Vries, Michiel S. (2007) "High expectations, varying outcomes: decentralization and participation in Brazil, Japan, Russia and Sweden" International Review of Administrative Sciences. Vol 73(3), pp. $424-451$ 
Anisimov, Alexander (2006) "V poiskakh razvivaiushchei modeli gosudarstva dlia Rossii.” Russian Expert Review No.5 (19).

Artobolevskiy, C., Gontmacher E. (eds.) (2010). Ob"edinenie sub"ektov Rossiiskoi Federatsii: za i protiv. Moscow.

Arzhanukhin S.V., Zerchaninova T.E. (2012) "Organizatsionnye patologii upravleniia kadrovym rezervom na gosudarstvennoi grazhdanskoi sluzhbe." Scientific Bulletin of the Ural Academy of Public Administration: politology, economics, sociology, law. No. 1(18). (Online) [URL http://vestnik.uapa.ru/ruru/issue/2012/01/13/] (Accessed June 2, 2013)

Aucoin, Peter (2012). “The Political-Administrative Design of NPM.” In Tom Christensen and Per Lægreid The Ashgate Research Companion to New Public Management. Burlington, VT: Ashgate,

Auriol, Emmanuelle and Picard, Pierre M. (2009) “Government Outsourcing: Public Contracting With Private Monopoly.” The Economic Journal, No.119 (October).

Balzer, Harley (2003) “Managed Pluralism: Vladimir Putin’s Emerging Regime” PostSoviet Affairs,Vol.19, No.3, pp. 189-227.

Barabashev, Aleksei, et all. (2006). Reforma Gosudarstvennoi sluzhby Rossiiskoi Federatsii. Moscow: Higher School of Economics.

Barabashev, Aleksei, et all. (2007). Riski reformirovaniia gosudarstvennoi sluzhby" Voprosy gosudarstvennogo i munitsipal'nogo upravleniia [Problems of state and municipal administration]. No.2., pp.91-124 
Barabashev, Aleksei. (2013). Evoliutsiia gosudarstvennoi sluzhby Rossii: itogi desiatiletiia (2000-2010). Moscow: HSE.

Barabashev, Aleksei; Klimenko Andrei (2010) Administrativnaia reforma i reforma gosudarstvennoi sluzhby'v Rossii-voprosy' realizatsii i koordinatsii. Moscow: Higher School of Economics.

Barabashev A., Straussman J.D. (2007). "Public Service Reform in Russia, 1996-2006.” Public Administration Review, Vol. 67, issue 3 (May-June), pp. 373-382.

Barry, Michael P. (2009) “Corruption In Russia: a model exploring its economic costs." Caucasian Review of International Affairs. Vol. 3(4), pp. 387-403

Bartles, Charles K. (2011). "Defense Reforms of Russian Defense Minister Anatolii Serdyukov." The Journal of Slavic Military Studies, Vol. 24, Issue 1, pp. 55 80.

Bartsits, Igor (ed.) (2011). Protivodeistvie korruptsii i modernizatsiia gosudarstvennogo upravleniia: opyt Rossii: analiticheskii doklad. Moscow: RANKhiGS

Beach, Derek; Pedersen, Rasmus Brun (2013) Process-Tracing Methods: Foundations and Guidelines. Ann Arbor: University of Michigan Press.

Berezdivina E.V. (2011) “Otsenka deiatel'nosti kontrol'no-nadzornykh organov ispolnitel'noi vlasti." Voprosy gosudarstvennogo i munitsipal'nogo upravleniia [Problems of state and municipal administration]. No.3., pp.2337

Bingham, Lisa Blomgren; Nabatchi, Tina; O’Leary, Rosemary (2005). “The New Governance: Practices and Processes for Stakeholder and Citizen Participation 
in the Work of Government." Public Administration Review. Vol. 65, No. 5, pp. 547-558.

Blöndal, Jón R. (2006). “International Experience Using Outsourcing, Public-Private Partnerships, and Vouchers.” In John M. Kamensky and Albert Morales (eds.) Competition, choice, and incentives in government programs. Toronto: Rowman \& Littlefield pp. 121-160.

Bogason, Peter (2008). "Public administration under postmodern conditions." Administrative Theory \& Praxis. Vol. 30, No. 3, pp. 359-362

Boje, David M. (2006). "What Happened on the Way to Postmodern? Part II." Administrative Theory \& Praxis Vol. 28, No. 4, pp. 479-494

Bouckaert, Geert and Halligan, John (2008). Managing Performance: International Comparisons. London: Routlege.

Bovaird, Tony (1996). Developing new forms of partnership with the 'market' in the procurement of public services.” Public Administration Vol. 84, No. 1, p. 147

Bovaird, Tony and Loffler, Elke (2003) "Evaluating the quality of public governance: indicators, models and methodologies." International Review of Administrative Sciences. Vol. 69(3), pp. 313-328

Bovaird, Tony and Loffler, Elke (2009) Public Management and Governance (2 ${ }^{\text {nd }}$ ed.) New York: Routlege.

Bovt, Georgii (2008) "Vladislav Surkov: A Pragmatic Idealism.” Russian Politics and Law, Vol. 46, No. 5, pp. 33-40.

Boyne, George A. (2002) "Public and Private Management: What's the Difference?" Journal of Management Studies. Vol.39, Issue 1, pp. 97-122. 
Boyne, George A.; Farrell, Catherine; Law, Jennifer; Powell, Martin; Walker, Richard M. (2003). Evaluating public management reform: principles and practice. Philadelphia: Open University Press.

Boyne, George A.; Meier, Kenneth J.; O’Toole, Laurence J. Jr.; Walker, Richard M. (2005). "Where Next? Research Directions on Performance in Public Organizations." Journal of Public Administration Research and Theory. Vol.15. pp. 633-639

Box, Richard C.; Marshall, Gary S.; Reed, B.J.; Reed, Christine M. (2001). "New Public Management and Substantive Democracy." Public Administration Review. Vol.61, No.5., pp.608-619.

Bremmer, Ian and Charap, Samuel. (2006-07). “The Siloviki in Putin's Russia: Who They Are and What They Want." The Washington Quarterly, Vol.30:1, pp. 83-92.

Brown, Archie (2001). "From Democratization to "Guided Democracy"." Journal of Democracy, Vol.12, No.4, pp. 35-41

Brzezinski, Z. (1997) The grand chessboard: American primacy and its geostrategic imperatives. NY: BasicBooks.

Brym, Robert J. and Gimpelson, Vladimir. (2004) "The Size, composition and Dynamics of the Russian State Bureaucracy in the 1990s," Slavic Review, Vol. 63 No.1. Buev, V.V.; Shekhovtseva, A.O. (2007) Administrativnaia reforma v Rossiiskoi Federatsii: sbornik statei. Moscow: NISSE

Bunce, Valerie (1995). “Should Transitologists Be Grounded?" Slavic Review, Vol. 54, No. 1, pp. 111-127 
Burnier, DeLysa. (2005). “Making It Meaning Full: Postmodern Public Administration and Symbolic Interactionism." Administrative Theory \& Praxis. Vol. 27, No. 3., pp. $498-516$

Busygina. Irina. "The President's representatives: problems of establishing and developing an institution.” Russian Politics and Law, 1997. Vol. 35(1). Buzin, Andrey (2007). Administrativnye izbiratel'nye tekhnologii i bor'ba s nimi”. Moscow: Panorama.

Byzov, Leontii (2006) “Biurokratiia pri V.Putine - sub”ekt razvitiia ili ego tormoz?" Sotsiologicheskie issledovaniia. No.3, pp.21-28.

Carr, Fergus; Massey, Andrew (eds.) (2006) Public Policy and the New European Agendas. Northampton, MA : Edward Elgar.

Carter, Neil; Klein, Rudolf; Day, Patricia (1992) How Organisations Measure Success: the use of performance indicators in government. New York: Routlege. Cheloukhine, Serguei; King, Joseph (2007). "Corruption networks as a sphere of investment activities in modern Russia." Communist and Post-Communist Studies. Vol. 40, pp.107-122

Chertkov, A. (2001) “O reforme Soveta Federatsii Rissiiskoi Federatsii”. Law and Politics, \#6.

Chirikova, Alla E. (2010). "The Power Vertical in the Assessments of Regional Elites: the Dynamics of Change." Russian Politics and Law, vol. 48, no. 1 (JanuaryFebruary), pp. 40-57

Christensen, Tom; Lægreid Per. (eds.) (2010). The Ashgate Research Companion to New Public Management. Burlington, VT: Ashgate. 
Christensen, Tom; Lægreid Per (2003). "Complex interactions and influence among political and administrative leaders." International Review of Administrative Sciences. Vol.69, pp. 385-400

Christensen, Tom; Lisheng, Dong; Painter, Martin (2008). "Administrative reform in China's central government: how much `learning from the West'?” International Review of Administrative Sciences. Vol.74, pp. 351-371.

Cobbold, Ian; Lawrie, Gavin (2002) The development of the Balanced Scorecard as a strategic management tool. Paper presented at PMA Conference, Boston, USA, May 2002. (Online) [URL:

http://memberfiles.freewebs.com/84/90/65819084/documents/Balace\%20Scor e\%20card-1.PDF] (accessed September 13, 2013).

Colton, T.J. and McFaul, M. (2003). Popular choice and managed democracy: the Russian elections of 1999 and 2000. Brookings Inst. Press.

Committee on Foreign Relations, US Congress (2001) The Putin administration's policies toward non-Russian regions of the Russian Federation. Washington: U.S. Government Printing Office.

De Bruijn, Hans (2002). Managing Performance in the Public Sector. New York: Routlege.

DeBardeleben, Joan and Zherebtsov Mikhail (2010) "The Transition to Managerial Patronage in Russia's Regions", in V. Gel'man and C.Ross (eds.) The Politics of Sub-National Authoritarianism in Russia. London: Ashgate pp. 85-106 
DeBardeleben, Joan and Zherebtsov Mikhail (2013) Economic Crisis, the Power Vertical, and Prospects for Liberalization in Russia. In DeBardeleben, J., Viju, C. (eds.) The Economic-Financial Crisis in Europe. New York: Ashgate

Debord, Guy (1977) The Society of the Spectacle. Detroit: Black and Red.

Demidova, Olga and Yakovlev, Andrey (2011). "Vliianie vzaimootnoshenii predpriiatii s vlastiami na uchastie predpriiatii b sisteme goszakupok: empiricheskii analiz.” Voprosy gosudarstvennogo I municipal'nogo upravleniia [Problems of state and municipal administration]. No.1., pp.133-156

Demidova, Olga; Yakovlev. Andrei (2012) "State-business relations and participation of firms in public procurement in Russia: an empirical study." Journal of Public Procurement, Vol. 12, Issue 4, pp. 563-588

Denhardt, Robert B.; Denhardt, Janet Vinzant (2000). “The New Public Service: Serving Rather than Steering.” Public Administration Review. Vol. 60, No. 6, pp. 549559.

Desai, Raj M.; Goldberg, Itzhak, (eds.) (2007) Enhancing Russia's Competitiveness and Innovative Capacity. Washington: The World Bank.

Diamond, Jack (2003). "Performance Budgeting: Managing the Reform Process.” IMF Working Paper, February., (Online) [URL: www.imf.org/external/pubs/ft/wp/2003/wp0333.pdf] (accessed: November 11, 2012).

Dibben, Pauline; Higgins, Paul (2004). "New Public Management: Marketization, Managerialism and Consumerism.” In Dibben, P., Wood G., Roper I. eds. 
Contesting Public Sector Reforms: critical perspectives, international debates. Palgrave Macmillan.

Diefenbach Thomas (2009). "New public management in public sector organizations: the dark sides of managerialistic 'enlightenment'." Public Administration Vol. 87, No. 4, pp.892-909.

Dobroliubova, E.I. (2008) "Vnedrenie printsipov i protsedur upravleniia po rezul'tatam v Rossiiskoi Federatsii: promezhutochnye itogi i napravleniia razvitiia." Voprosy gosudarstvennogo i munitsipalnogo upravleniia. No.3. p. 65-133.

Dong, Lisheng, Christensen Tom and Painter, Martin (2010) “A Case Study of China's Administrative Reform : The Importation of the Super-Department" The American Review of Public Administration. Vol.40, No.2, pp. 170-188

Drechsler, Wolfgang (2004) "Governance, Good Governance, and Government: The Case For Estonian Administrative Capacity" TRAMES, Issue No.4. pp.388396

Drechsler, Wolfgang (2005) "The Re-Emergence of "Weberian" Public Administration after the Fall of New Public Management: The Central and Eastern European Perspective" Halduskultuur, Vol 6, pp. 94-108.

Drechsler, Wolfgang (2005) "The Rise and Demise of the New Public Management". Post-autistic economic review, Issue No 33, September, pp.17-28

D'Souza, Jayesh (2007). Public administration and the new public management: a case study of budgetary reform in the United Kingdom. (Online) [URL: http://www.spaef.com/file.php?id=187]. (Accessed: May 14, 2012). 
Dunleavy, Patrick et all. (2005). "New Public management is Dead - Long Live DigitalEra Governance." Journal of Public Administration Research and Theory. Vol.16 pp.467-494.

Dunn, William N. \& Miller, David Y. (2007). "A Critique of the New Public Management and the Neo-Weberian State: Advancing a Critical Theory of Administrative Reform.” Public Organization Revue. Vol.7.

Eden, Ron; Hyndman, Noel. (1999) "Performance measurement in the UK public sector: Poisoned chalice or Holy Grail?" Optimum, The Journal of Public Sector Management. Vol. 29, No. 1

Enikolopov, Ruben et all. (2011). "Media and Political Persuasion: Evidence from Russia”. American Economic Review Volume 101:7. pp. 3253-85

Evance, Bryan and Shields, John (1998). Shrinking the state: Globalization and public administration "reform". Halifax, N.S.: Fernwood

Ewalt, Jo Ann G. (2001) “Theories of Governance and New Public Management: Links to Understanding Welfare Policy Implementation”. Prepared for presentation at the Annual conference of the American Society for Public Administration.

Farmer, David J. (1995) The Language of Public Administration: Bureaucracy, Modernity and Postmodernity. Tuscaloosa: University of Alabama Press Feklyunina, Valentina (2008). "Battle for Perceptions: Projecting Russia in the West." Europe-Asia Studies Vol. 60, No. 4, pp. 605 - 629.

Feklyunina, Valentina and White, Stephen (2011). “Discourses of 'Krizis': Economic Crisis in Russia and Regime Legitimacy." Journal of Communist Studies and Transition Politics, Vol.27, Nos.3-4., pp.385-406 
Ferlie, Ewan; Lynn, Laurence E.; Pollitt, Christopher (eds.) (2005). The Oxford handbook of public management. Oxford: Oxford University Press.

Ferlie, Ewan; Pettigrew, Andrew; Ashburner, Lynn; Fitzgerald, Louise (1996) The New Public Management in Action. Oxford: Oxford University Press.

Ferris, James M.; Tang, Shui-Yan (1993). “The New Institutionalism and Public Administration: An Overview." Journal of Public Administration Research and Theory. Vol. 3, No. 1, pp. 4-10

Frederickson, H. George et all. (eds.) (2012). The Public Administration Theory Primer. $2^{\text {nd }}$ ed. Boulder: Westview Press

Forbes, Melissa; Lynn, Laurence E. Jr. (2005). "How Does Public Management Affect Government Performance? Findings from International Research.” Journal of Public Administration Research and Theory. Vol.15, pp. 559-584

Ford, J.Kevin; et. al. (1989). "Process tracing methods: contributions, problems, and neglected research questions.” Organizational Behavior and Human Decision Processes. Vol. 43, pp. 75-117

Gabrielian, Vatche (1999). "Post-communist bureaucracies: organizational modes of transition." International Journal of Public Administration. Vol. 22(1), pp. 3968.

Gabrielian, Vatche; Holze, Marc (1999). "Post-soviet bureaucracy: change and continuity." International Journal of Public Administration. Vol. 22(1), pp. 111. 
Garaev, S.N. (2008) “Administrativnaia reforma kak sposob povy'sheniya legitimnosti gosudarstvennoi vlasti v sovremennoi Rossii” Bulletin of The Peoples' Friendship University of Russia. No. 4, pp. 17-24.

Geddes, Barbara (1999). "What do we know about democratization after twenty years?" Annual Review of Political Science. Vol.2, pp.115-144

Gel'man, Vladimir (2007) “Ot mestnogo samoupravleiia - k vertikali vlasti” Pro et Contra, No.1 (35). Moscow: Moscow Carnegi Center.

Gel'man, Vladimir (2008). "Party Politics in Russia: From Competition to Hierarchy." Europe-Asia Studies. Vol. 60, No. 6, pp. 913 - 930

Giauque, David (2003). "New Public Management and Organizational Regulation: the Liberal Bureaucracy.” International Review of Administrative Sciences, Vol.69, pp. 567-592.

Gill, Jeff; Witko, Christopher (2013). "Bayesian Analytical Methods: A Methodological Prescription for Public Administration." Journal of Public Administration Research and Theory. Vol.23, pp. 457-494.

Gilmour, John B. (2007) “Implementing OMB’s Program Assessment Rating Tool: Meeting the Challenges of Performance-Based Budgeting." in F. Stevens Redburn et.al. (eds). Performance Management and Budgeting: How Governments Can Learn from Experience. M.E.Sharpe: Armonk, NY

Gilmour, John B.; Lewis, David E. (2005). “Assessing Performance Budgeting at OMB: The Influence of Politics, Performance, and Program Size.” Journal of Public Administration Research and Theory. Vol. 16, pp. 169-186. 
Gimpelson, Vladimir (2002). “Chislennost' i sostav rossiiskoi biurokratii.” Voprosy Ekonomiki. No. 11 pp. 91-107.

Gimpelson, Vladimir (2003). "The Size and Composition of the Russian Bureaucracy." Problems of Economic Transition, Vol. 46, No. 5, pp. 52-78.

Goetz, Klaus H. (2001). “Making sense of post-communist central administration: modernization, Europeanization or Latinization?” Journal of European Public Policy. Vol.8, No.6, pp. 1032-1051.

Golosov, Grigorii V. (2012). “The 2012 Political Reform in Russia: The Interplay of Liberalizing Concessions and Authoritarian Corrections." Problems of PostCommunism, Vol. 59, No. 6, pp. 3-14.

Goode, J. Paul. (2005). “Rossiia pri Putine: ukrupnenie regionov.” Logos 1(46). Gorenburg, Dmitry (2010). “Center-Periphery Relations After Ten Years of Centralization." Russian Politics and Law, vol. 48, no. 1, pp. 3-7.

Groeneveld, Sandra; Van De Walle, Steven (2011) "New Steering Concepts in Public Management" Research in Public Policy Analysis and Management. Vol.21., pp.11-24.

Hahn, Gordon (1998) "From Chernomyrdin to Kirienko: The Rise of the Nizhnii Novgorod Group.” Problems of Post-Communism, Vol.45 No.5, pp.3-16. Hague, M.Shamsul (2001). “The Diminishing Publicness of Public Service Under the Current Mode of Governance" Public Adminisyration Review, Vol.61, No.1, pp. $65-82$

Hammouya, Messaoud (1999) Statistics on Public Sector Employment: Methodology, Structures and Trends. Geneva: ILO |online| (URL 
http://www.ilo.org/public/english/bureau/stat/download/wp_pse_e.pdf).

(Accessed May 20, 2012).

Hale, Henry E., McFaul, Michael, and Colton, Timothy J. (2004) "Putin and the

"Delegative Democracy" Trap: Evidence from Russia's 2003-04 Elections"

Post-Soviet Affairs, Vol. 20, No. 4, pp. 285-319.

Hann, Gordon (1998) "From Chernomyrdin to Kirienko: the rise of the Nizhnii Novgorod group" Problems of Post-Communism. Vol. 45, No.5 pp.3-16

Hann, Gordon (2003) “The Impact of Putin's Federative Reforms on Democratization in Russia" Post-Soviet Affairs, Vol.19, No.2, pp. 114-153.

Heinrich, Carolyn J. (2002). "Outcomes-Based Performance Management in the Public Sector: Implications for Government Accountability and Effectiveness.” Public Administration Review. Vol.62, No.6, pp.712-725.

Hedlund, Stefan (2006). "Vladimir the Great, Grand Prince of Muscovy: Resurrecting the Russian Service State.” Europe-Asia Studies Vol. 58, No. 5, pp. 775 - 801 Hellman, Joel S.; Jones, Geraint; Kaufmann, Daniel (2000) “Seize the State, Seize the Day." State Capture, Corruption, and Influence in Transition. World Bank Policy Research Working Paper No.2444. Online: [URL:

http://papers.ssrn.com/sol3/papers.cfm?abstract_id=240555] (Accessed: June 22, 2013).

Hernes, Tor (2005) "Four ideal-type organizational responses to New Public Management reforms and some consequences." International Review of Administrative Sciences, Vol. 71(1); pp.5-17 
Hood, Christopher (1991) “A Public Management for all Seasons" Public Administration Vol. 69, pp.3-19.

Hood, Christopher (1995) "The "New Public Management" in the 1980s: Variations on a Theme.” Accounting Organizations and Society, Vol. 20, No.2/3

Hood, Christopher, Peters, Guy (2004) "The Middle Aging of New Public Management: Into the Age of Paradox." Journal of Public Administration Research and Theory, Vol. 14, no. 3, pp. 267-282.

Hough, Jerry F. and Fainsod, Merle (1979). How the Soviet Union is governed. Cambridge: Harvard University Press.

Huskey, Eugene (2003). Nomenklatura Lite? The Cadres Reserve in Russian Public Administration. Washington: NCEER.

Huskey, Eugene (2004). "From Higher Party Schools to Academies of State Service: The Marketization of Bureaucratic Training in Russia." Slavic Review, Vol. 63, No. 2 (Summer, 2004), pp. 325-348.

Huskey, Eugene (2010). "Elite recruitment and state-society relations in technocratic authoritarian regimes: the Russian case." Communist and Post-Communist Studies, Vol. 43, pp. 363-372

Ivanov, A.E. (2009) “Gosudarstvennye zakupki v Evropeiskom Soyuze i Rossiiskoi Federatsii: posle zakonodatelnykh potriasenii," in Yasin, Evgeniy. (ed.) Modernizatsiia ekonomiki i globalizatsiia. Vol.3. Moscow: Higher School of Economics., pp. 662-673. 
Ivanov, Andrei (2011) "Sovremennyi etap razvitiia sistemy gosudarstvennyh zakupok Rossiiskoi Federatsii: "effektivnost" auktsiona i korruptsionnost konkursa." Goszakaz:, No.24.

Jakobson, Lev (2001) "Public management in Russia: changes and inertia." International Public Management Journal. Vol.4, pp. 27-48

Jordan, Meagan M.; Hackbart, Merl M. (1999) "Performance Budgeting and Performance Funding in the States: A Status Assessment.” Public Budgeting \& Finance. Vol.19 Issue 1.,

Jung, Chan Su (2012) "Navigating a Rough Terrain of Public Management: Examining the Relationship between Organizational Size and Effectiveness" Journal of Public Administration Research and Theory. Vol.23(3), pp. 663-686.

Kahn, Jeffrey; Trochev, Alexei; Balayan, Nikolai. (2009). "The Unification of Law in the Russian Federation." Post-Soviet Affairs, 25(4), pp. 310-346.

Kalgin, Alexander (2012). 'Upravlenie po rezul'tatam na regional'nom urovne: kontrol' ili rezul'tativnost'?" Voprosy gosudarstvennogo i munitsipalnogo upravleniia. No.3.p. $35-60$

Kamensky, John M., Morales, Albert (eds.), (2006) Competition, Choice And Incentives in Government Programs. Toronto: Rowman \& Littlefield Kara-Murza, Sergei (1999). Istoriia sovetskogo gosudarstva i prava. Moscow: "Bylina" Kellermann, Alfred E. (2007) “The Impact of EU Accession on the Development of Administrative Capacities in the States in Central and Eastern Europe. Similar Developments in Russia?" Romanian Journal of European Affairs 
Keraudren Philippe., von Mierlo, Hans. (1994) “Theories of Public Management reforms and their Practical implications." In D. Coombs and T. Verheijen (eds.) Public Management Reform. Comparative Experiences from East and West, ACEPhare Project

Kettle, Donald F. (2005) The Global Public Management Revolution, $2^{\text {nd }}$ ed., Washington D.C.: Brookings Institute Press

Khinshtein, Alexander (2006). Yeltsin. Kreml', Istoriia bolezni. Moscow: Olma Media. Kickert, Walter J.M. (2011). "Public Management Reform in Continental Europe: National Distinctiveness." in Christensen T., Lægreid P. (eds.) The Ashgate Research Companion to New Public Management. Burlington, VT: Ashgate.

King, Cheryl Simrell. (2005). "Postmodern Public Administration: In the Shadow of Postmodernism.” Administrative Theory \& Praxis Vol. 27, No. 3, pp. 517-532

Klimanov, V.V. (2000) Regional'noe razvitie i ekonomicheskaia samostoiatelnost' subiectov Rossiiskoi Federatsii M.

Kolosov, Vladimir and Turovskii, Rostislav (1996) “Elektoral'naia karta soveremennoi Rossii: genesis, struktura, evolutsiia." Polis. No.4 pp.33-47.

Konig, Klaus (2003) “On the typology of public administration” International Review of Administrative Sciences, Vol.69, No.4.

Kotchegura, Alexander (2008) Civil Service Reform in Post-Communist Countries. Leiden: Leiden University Press

Nikita Krichevskiy (2009) Postpikalevskaia Rossiia: novaia politiko-ekonomicheskaia real'nost. Moscow. 
Kryshtanovskaya, Ol'ga (2011) “The Tandem and the Crisis." Journal of Communist Studies and Transition Politics, Vol.27, No.3-4, pp.407-419

Kryshtanovskaya, Ol'ga and White, Stephen. (2003). "Putin's Militocracy." Post-Soviet Affairs, 19:4, pp. 289-306.

Kuchins, Andrew C. (2006) "Russian Democracy and Civil Society: Back to the Future" - Testimony Prepared for U.S. Commission on Security and Cooperation in Europe "Human Rights, Civil Society, and Democratic Governance in Russia: Current Situation and Prospects for the Future"

Kulikov, M. (2002) "Public Administration Reform" Problems of Economic Transition, Vol. 45, No.5, pp. 67-81

Lankina, Tomila V. (2005) "President Putin's local government reforms" In: Reddaway, Peter and Orttung, Robert W., (eds.) The dynamics of Russian politics: Putin's reform of federal-regional relations. Rowman \& Littlefield, Lanham

Latham, Gary P.; Borgogni, Laura; Petitta, Laura (2008) “Goal Setting and Performance Management in the Public Sector" International Public Management Journal Vol. 11, No. 4

Leeuw, Frans L. (1996) "Performance auditing, new public management and performance improvement: questions and answers." Accounting, Auditing \& Accountability Journal, Vol. 9 No. 2, pp. 92-102.

Lehmbruch, B. (2005) "The state, the market and the shadow economy: Survival strategies of Russian state institutions.” Osteuropa, Vol.55 Issue 10. 
Leksin, V. et.al. (2006) Administrativnaia reforma v Rossiiskoi Federatsii.

Normativnaia baza, problemy realizatsii, rekomendatsii. ARCADIS BMB /

GOPA / VNG International / ILPP.,

Leksin, V. (2006) Administrativnaia reforma i otsenka kachestva gosudarstvennogo upravleniia. Moscow: Russian Academy of Science.

Lesage, M. (1993) "The Crisis of Public-Administration in Russia" Public Administration, Vol.71 Issue 1-2, pp. 121-133

Liff, Stewart. (2011) Improving the Performance Of Government Employees: a Manager's Guide. New York: AMACOM.

Lipman, Maria (2009). "Media Manipulation and Political Control in Russia." Russia and Eurasia Programme: REP PP 09/01 London: Chatham House Lipman, Maria and McFaul, Michael (2001) "Managed Democracy in Russia". The Harvard International Journal of Press/Politics 6(3). pp. 116-127

Logunov, A. (ed.), (2006) “Administrativnaia reforma v Rossiiskoi Federatsii: osnovnye etapy realizatsii." Analytical Bulletin of the Federation Council of the Russian Federation. Ser.: Problems of State-Building No. 22(310)

Maheshwary, Shriram R. (2002). A Dictionary of Public Administration. New Dehli: Orient Longman.

Makeyenko, Pavel A.; Gabrielian, Vatche; Holzer, Marc (1999) “The New Russian Bureaucracy: What Is New About It?" International Journal of Public administration., Vol.22(1), pp. 13-37. 
Manning, Nick (2000). Public Officials and Their Institutional Environment: An Analytical Model for Assessing the Impact of Institutional Changes. Washington: The World Bank.

Manning, Nick (2002). Building on Strengths: Lessons from Comparative Public Administration Reforms. Washington: The World Bank.

Manning, Nick; Parison, Neil. (2004). International public administration reform: implications for the Russian Federation. Washington: The World Bank.

March, James G. and Olsen, Johan P. (1984). “The New Institutionalism: Organizational Factors in Political Life." The American Political Science Review, Vol. 78, No.3, pp. 734-749.

Mar'iasin D.S. (2006) “Administrativnaia reforma kak process samoobucheniia gosudarstva" Bulletin of Moscow State University., Ser.21 (State and Society), No.4

Markaryan, Karen (2006). "Strategiia: Rossiia kak gosudarstvo-korporatsiia." Politicheskii klass, January, 1.

Marsh, David; Smith, Martin (2000) "Understanding Policy Networks: towards a Dialectical Approach.” Political Studies, Vol. 48, pp.4-21

Marshall, Gary S. and White, Orion F. Jr. (1990). "The Blacksburg Manifesto and the Postmodern Debate: Public Administration in a Time Without a Name.” American Review of Public Administration. Vol.20, No.2. pp. 61-76

Mart'ianov, Viktor (2007). "The Decline of Public Politics in Russia: From Public Politics to Political Administration." Russian Politics and Law, vol. 45, no. 5, pp. $67-82$. 
Martin, Stephen; Smith, Peter C. (2005) "Multiple Public Service Performance Indicators: Toward an Integrated Statistical Approach.” Journal of Public Administration Research and Theory, Vol. 15, pp. 599-613

Mashaw, Jerry L. (1991) “The Fear of Discretion in Government Procurement” Yale Journal on Regulation Vol. 8 pp. 511-513

Mau, Vladimir et al. (eds.) (2007). Instituty zakrytykh demokratii: popytka sravnitel'nogo analiza. Moscow: IEPP.

McAllister Ian \& White Stephen (2008) “'It's the Economy, Comrade!' Parties and Voters in the 2007 Russian Duma Election" Europe-Asia Studies, Vol. 60, No.6, pp. $931-957$

Meyer, Kenneth J. and O'Toole, Laurence J. Jr. (2006) Bureaucracy in a Democratic State: A Governance Perspective. Baltimore: Johns Hopkins University Press.

Mises, Ludwig von (1962) Bureaucracy. New Haven: Yale Morgan-Jones, Edward and Schleiter, Petra (2004) "Governmental Change in a President-Parliamentary Regime: The Case of Russia 1994-2003" Post-Soviet Affairs, Vol.20, No.2, pp. 132-163.

Naryshkin, Sergei; Khabrieva, Tatiana (eds.) (2006) Administrativnaia reforma v Rossii. Moscow: Infra-M.

Naryshkin, Sergei (2007) “Administrativnaia reforma: pervye shagi i perspektivy” Problems of State and Municipal government. Vol. 1, No.1; pp.8-15

Netter, Jeffry M.; Megginson, William L. (2001). "From state to market: a survey of empirical studies on privatization." Journal of Economic Literature, vol. 39, pp. 321-89. 
Nickel Patricia, Mooney; (2007) "Network Governance And The New Constitutionalism" Administrative Theory \& Praxis Vol. 29, No. 2, pp. 198-224

Nikolaev, I.A.; Shul'ga, I.E. (2002) Glavnoe v administrativnoi reforme. Analiticheskii Doklad. Moscow: FBK

Nisnevich, Iulii (2008). “Administrativnaia Reforma: tseli i rezul'taty. Bulletin of the Peoples' Friendship University. Ser.: Political Science, No. 4.

Nosova, Natalia (2001). Istoriia gosudarstvennogo upravleniia Rossii (IX-XX vv.).

Nozdrachev A. (2005) “Administrativnaia Reforma: Rossiiskii variant” Zakonodatel'stvo i ekonomika, [Legislation and economy], No. 8-9.

Nunberg, Barbara (1999) The State After Communism: Administrative Transitions in Central and Eastern Europe. Washington, D.C.: The World Bank

Oates, Sarah (2011). "The Media in Russia. The Slavonic and East European Review." Vol. 89 No.2 pp. 388-389

Obolonskii, Alexander. (1996) "Postsovetskoe chinovnichestvo: kvazibiurokraticheskii praviashchii klass." Obshchestvennye nauki i sovremennost'. No.5

Obolonskii, Alexander (1999) "Reform of the Russian state service: conception and strategy" Social Sciences, Vol. 30, No. 1, pp. 33-44

Obolonskii, Alexander (2009) Gosudarstvennaia sluzhba: kompleksnyi podhod. Moscow: Delo.

OECD (2005). Fighting Corruption and Promoting Integrity in Public Procurement. OECD Publishing.

Okara, Andrei (2007). "Sovereign Democracy: A New Russian Idea or a PR Project?" Russia in Global Affairs. No.2, July - September. 
Okun'kov, Lev (1998). “Pravitel'stvo i Prezident: grani vzaimodeistviia." Journal of Russian Law. No.9

Okun'kov, Lev (2001). “Pravitel'stvo i Prezident: v mekhanizme gosudarstvennoi vlasti." Journal of Russian Law. No.9

Oleinik, Anton (ed.) (2009) Reforming the State without Changing the Model of Power? New York: Routlege.

“Organy ispolnitel'noi vlasti: funktsii, tipy, ekonomicheskii mehanizm.” (2002) Report of the Higher School of Economics., pp. 1-33 (Online), [URL: http://www.hse.ru/data/644/325/1234/report2.pdf] (Accessed May, 11, 2013).

Orlova A. (2008). "Corruption in Russia - On the myth of the market and the state as antidote." Osteuropa, Vol.58 Issue. 1, pp. 21-34

Osborne, David; Gaebler, Ted. (1992). Reinventing Government: How the Entrepreneurial Spirit is Transforming the Public Sector. Reading, MA: Addison-Wesley.

Osborne, Stephen P. (ed.) (2010) The New Public Governance? Emerging Perspective on the Theory and Practice of Public Governance. New York: Routlege

Oseichuk V. (2010) “Kak preodolet’ kadrovyi golod na grazhdanskoi i munitsipalnoi sluzhbe?" Gosudarstvennaia sluzhba. No.2.

Page, Edward C. (2012) Policy without politicians: bureaucratic influence in comparative perspective. Oxford: Oxford University Press.

Parison, Neil; Evans, Gary (2005) “Administrativnaia Reforma v Rossiiskoi Federatsii” Bulletin of Moscow State University., Ser.21 (State and Society), No.2 
Pavlovskiy, Gleb “Upravliaemaia” demokrtatiia, ili prosto - opytnaia?” "'Guided” Democracy or Just an Experimental One? ") // Russian Journal, July 1, 2009; available on-line at: http://www.russ.ru/Mirovaya-povestka/Upravlyaemayademokratiya-ili-prosto-opytnaya. (Accessed on May 15, 2011).

Peregudov, Sergei (2006) "Civil Society as an Agent of Public Politics.” Russian Politics and Law, Vol. 44, No. 6, pp. 50-66.

Peters, B. Guy (2001). The Future of Governing. $2^{\text {nd }}$ ed. University Press of Kansas. Petrov, Nikolai, (2002) “Seven faces of Putin's Russia: federal districts as the new level of state-territorial composition.” Security Dialogue, Vol. 33(1). pp. 73-91

Petrov, Nikolai, Mikheev, Sergei \& Smirnyagin, Leonid, (1993). "Russia’s Regional Associations in Decline", Post-Soviet Geography, vol. 34, no. 1, pp. 59-68. Petukhov, Vladimir (2006) “Biurocratiia i vlast” Sotsiologicheskie issledovaniia. No.3, pp. $9-15$

Podbelskii N.V. (2010) Teoretiko-metodologicheskie osnovy postroeniia $i$ funktsionirovaniia regionalnykh sistem rezerva upravlencheskikh kadrov. Abstract of the Dissertation. Institute of Economy, Ural's division of the Russian Academy of Science. p.18 (Online) [URL: http://economylib.com/disser/38164/a?\#?page=1] (Accessed June 3, 2013)

Pollitt, Christopher; Bouckaert, Geert. (2004). Public Management Reform: A Comparative Analysis ( $2^{\text {nd }}$ ed.) Oxford: Oxford University Press. Pollitt, Christopher, Van Thiel, Sandra, Homburg, Vincent. (eds.), (2007) The New Public Management in Europe: Adaptation and Alternatives. NY: Palgrave Macmillan 
Popov, Gavriil (1987). "S tochki zreniia ekonomista.” Nauka i Zhizn No.4

Protsyk, Oleh (2006) "Intra-Executive Competition between President and Prime Minister: Patterns of Institutional Conflict and Cooperation under SemiPresidentialism.” Political Studies 54:2. pp. 219-244

Public Sector Reform: What Works and Why? (2008) Washington: World Bank.

Redburn, F. Stevens et.al. (eds). (2007) Performance Management and Budgeting: How Governments Can Learn from Experience. M.E.Sharpe: Armonk, NY

Remington, Thomas (2008). "Patronage and the Party of Power: President-Parliament Relations Under Vladimir Putin.” Europe-Asia Studies Vol. 60, No. 6, pp. 959 $-987$

Roberts, Cynthia and Sherlock, Thomas (1999) "Bringing the Russian State Back in: Explanations of the Derailed Transition to Market Democracy" Comparative Politics, Vol. 31, No. 4, pp. 477-498

Rohr, John A. (2005) “French Public Administration.” in Krishna K. Tummala (ed.) Comparative Bureaucratic Systems. Lanham: Lexington Books.

Rosenberg, Gerald N. (1993) “The Real World of Democratic Community” in Chapman, John. W. and Shapiro, Ian (eds.) Democratic Community: NOMOS XXXV. New York: New York University Press., pp.228-258

Ross. Cameron. (2003). "Putin's federal reforms and the consolidation of federalism in Russia: one step forward, two steps back!" Communist and Post-Communist Studies Vol. 36, pp. 29-47.

Ross, Cameron (2010). “Federalism and inter-governmental relations in Russia.” Journal of Communist Studies and Transition Politics. Vol.26, Issue 2. 
Sabatier, Paul A. (1992) “Toward Better Theories of the Policy Process" PS: Political Science \& Politics. Vol.24(2), pp.147-56.

Sakwa, Richard. (2004). Putin: Russia's choice. New York: Routlege

Salikov M.S. (1998) “O preimuschestvakh I vozmozhnostiakh sozdaniia territorial'noi federatsii." Polis, No.5.

Savas, E. S. (2005) Privatization in the City: Successes, Failures, Lessons. Washington, DC: CQ Press.

Schaaf, Matthew, Lokshina Tatiana. (2009) “An uncivil approach to civil society: continuing state curbs on independent NGOs and activists in Russia." Human Rights Watch.

Schmitter Philippe C. and Karl, Terry Lynn (1994) "The Conceptual Travels of Transitologists and Consolidologists: How Far to the East Should They Attempt to Go?" Slavic Review, Vol. 53, No. 1, pp. 173-185.

Sedova, Natalia (2006). "Effektovnost biurokratii v otsenkakh rossiian" Sotsiologicheskie issledovaniia. No.3, pp. 15-20

Sharov, Andrei (ed.) (2006) Reforma Gosudarstvennogo Upravleniia: Vzgliad Iznutri. Moscow.

Shea, Robert J. (2008) "Performance Budgeting in the United States." OECD Journal on Budgeting. Vol.8 No. 1.

Shevchenko, Iulia (2004). The central government of Russia: from Gorbachev to Putin. Burlington: Ashgate.

Shevtsova, Lilia (2000). “Ot Rossii Yeltsina k Rossii Putina." Contemporary Europe Vol.4. 
Shevtsova, Lilia (2001). "Russia’s Hybrid Regime” Journal of Democracy, Vol.12, No.4, pp. $65-70$

Shevtsova, Lilia (2004). "The limits of bureaucratic authoritarianism" Journal of Democracy, Vol. 15, No.3, pp.67-77

Shevtsova, Lilia (2007). Russia: Lost in Transition: The Yeltsin and Putin Legacies. Washington: Carnegie Endowment.

Shlapentokh, Vladimir (2006) "Trust in public institutions in Russia: The lowest in the world" Communist and Post-Communist Studies Vol.39, pp.153-174

Shlapentokh, Vladimir and Woods Joshua (2006). Contemporary Russia as a feudal society : a new perspective on the post-Soviet era. New York: Palgrave Macmillan

Semenov, V. (2010) “O povyshenii kachestva nauchno-metodicheskogo i informatsionno-analiticheskogo obespecheniia protsessa reformirovaniia $\mathrm{i}$ razvitiia gosudarstvennoi i munitsipalnoi sluzhby.” Doklad. [Online] [URL: http://www.ucs-ms.ru/ed.php?id=47]. (Acessed 03.06.2013).

Semenov, V. (2010). "Za kachestvo upravlencheskikh kadrov." Gosudarstvennaia Sluzhba. No. 6. p. 11.

Skelcher, Chris (2005). "Public-Private Partnerships and Hybridity." in Ewan Ferlie, Laurence E. Lynn, Christopher Pollitt (eds.) The Oxford Handbook Of Public Management. NY: Oxford University Press.

Slatinov, Boris (2006) "Promezhutochnye itogi administrativnoi reform" Bulletin of Moscow State University, Ser. 21. No.4, pp.1-10 
Slider, Darrel (2005). "The regions' Impact on Federal Policy: The Federation Council”, in Peter Reddaway and Robert W. Orttung (eds). The Dynamics of Russian Politics: Putin's Reform of Federal-Regional Relations. Volume 2., Oxford: Rowman \& Littlefield Publishers.

Smorgunov, Leonid (2008) “Administrativnaia reforma v regionakh: mesto IKT v strategiakh razvitiia." Internet i Sovremennoe obshchestvo: Trudy XI Vserossiiskoi Conferentsii. Saint-Petersburg: SPbGU

Smith, Mark A (2006) Sovereign Democracy: the Ideology of Yedinaya Rossiya. Watchfield, England: Conflict Studies Research Centre

Smith, Peter (1990) “The Use of Performance Indicators in the Public Sector" Journal of the Royal Statistical Society. Series A (Statistics in Society). Vol.153, No.1, pp.53-72.

Smyth, Regina; Lowry, Anna; and Wilkening, Brandon (2007) “Engineering Victory: Institutional Reform, Informal Institutions, and the Formation of a Hegemonic Party Regime in the Russian Federation.” Post-Soviet Affairs, Vol.23, No.2, pp. 118-137.

Sokolowski Alexander (2001) "Bankrupt Government: Intra-Executive Relations and the Politics of Budgetary Irresponsibility in El'tsin's Russia" Europe-Asia Studies, Vol. 53, No. 4, pp.541-572

Solomon, Peter (2008) "Law in Public Administration: How Russia Differs" Journal of Communist Studies and Transition Politics, Vol.24, No.1 
Soloviov, Alexander (2004) “Administrativnaia reforma kak politicheskii proekt praviashhego rezhima." Bulletin of Moscow State University., Ser.21 (State and Society), No.4; pp.1-10

Sperling, Valerie (2009).Altered States: The Globalization of Accountability. New York: Cambridge University Press

Spilimbergo, Antonio (2007) "Measuring the Performance of Fiscal Policy in Russia" Emerging Markets Finance and Trade, vol. 43, no. 6, pp. 25-44.

Stavrakis, Peter J. (1993) State Building in Post-Soviet Russia: The Chicago Boys and the Decline of Administrative Capacity. Washington: Kennan Institute.

Stigler, G. J. (1971). “The Theory of Economic Regulation.” The Bell Journal of Economics and Management Science, Vol. 2(1)., pp. 3-21

Sun, Yan (1999). "Reform, State, and Corruption: Is Corruption Less Destructive in China than in Russia?" Comparative Politics, Vol. 32, No. 1, pp. 1-20

Surkov, Vladislav (2008) "Russian Political Culture The View from Utopia” Russian Politics and Law, Vol. 46, No. 5, pp. 10-26.

Sutela, Pekka (1999). Russia: the state and future of the economy. BOFIT Online No. 4. pp. $1-14$

Talbot, Colin (2005). "Performance Management." in Ewan Ferlie, Laurence E. Lynn, Jr. and Christopher Pollitt (eds). The Oxford Handbook of Public Management. Oxford, UK: Oxford University Press

Tikhonova, Natalia (2003) "Biurokratiia: chast' obshchestva ili ego kontragent?" Sotsiologicheskie issledovaniia. No.9 
The Next Steps Initiative (1989) London: HMSO Publications Centre. (Online) [URL: http://www.official-documents.gov.uk/document/hc8889/hc04/0410/0410.pdf] (Accessed: September 14, 2013).

Thompson, Fred and Jones, L. R. (2008) "Reaping the advantages of information and modern technology: moving from bureaucracy to hyperarchy and netcentricity” International Public Management Review, Vol.9 Issue 1. pp. $148-193$

Treisman, Daniel (2010) “'Loans for Shares”| Revisited” Post-Soviet Affairs, Vol.26, No.3, pp. 207-227

Treisman, Daniel (2002) “Russia Renewed?” Foreign Affairs. Vol.81, No.6, pp.58-72

Turovskii, Rostislav F. (2010) "How Russian Governors are Appointed: Inertia and Radicalism in Central Policy" Russian Politics and Law, vol. 48, no. 1, pp. $58-79$.

Vaksova, Evgeniia, Karaseva, Anna (2012). Primenenie mekhanizmov autsorsinga na federal'nom urovne. Biudget., No.5

Ventriss, Curtis. The Postmodern Condition and the Challenge of Rethinking the Foundations of Public Policy and Administration: a Critical Inquiry. Administrative Theory \& Praxis Vol. 27, No. 3, 2005: 552-560

Vigoda, Eran (2002). "The Legacy of Public Administration: Background and Review." In Vigoda. E. (ed.) Public Administration: an Interdisciplinary Critical Analysis. New York: Marcel Dekker.

Vishniakov, Viktor (2011) “Administrativnaia Reforma: 15 let poiskov kontseptsii.” Zakonodatel'stvo i ekonomika, No. 7. 
"Vlast I biurokratiia v novoi Rossii" (2006) Sotsiologicheskie issledovaniia. No.3, pp.3-8

Vorontsova, A. V., Zvonovsky, V. B. (2003) “Administrativnyi resurs kak fenomen rossiiskogo izbiratel'nogo protsessa'”, Polis, 6.

Voslenskii, Mikhail. (1989) Nomenklatura. Gospodstvuyuschii klass Sovetskogo Soyuza. Moscow: Sovetskaia Rossiia

Wamsley, Garry et. all. (1990) Refounding Public Administration. Newbury Park, CA: Sage Publications.

Wilson, Kenneth (2006) "Party-System Development Under Putin.” Post-Soviet Affairs, No. 22:4, p. 317.

White, Stephen (2001). “Elections Russian-Style.” Europe-Asia Studies, Vol.63(4), p.533 White, Stephen; Kryshtanovskaya, Olga (2011). "Changing the Russian Electoral System: Inside the Black Box”, Europe-Asia Studies, Vol. 63:4

World Bank. (2006) Russian Federation. Country Procurement Assessment Report. Operational Policy and Services. The World Bank: Europe and Central Asia Region .

Yakovlev, Andrei, et. al. (2010) HSE Policy paper: The system of public procurements in Russia: on the road of reform. Moscow: Higher School of Economics.

Yakovlev, Andrei et.al. (2010) Sistema goszakupok: na puti k novomu kachestvu. Moscow: Higher School of Economics.

Yakovlev, Andrei et.al. (2010) The system of public procurements in Russia: on the road of reform. HSE policy paper 
Yakovlev, Andrei (2012). "Sistema goszakupok v Rossii: na poroge tretiei reform." Obschestvennye nauki i sovremennost [Social Sciences and the Modernity], No.5, pp. 55-70.

Yakovlev, Andrei and Demidova, Olga (2010) Reforma sistemy goszakupok i praktika otbora postabschikov dlia gosudarstvennyh nuzhd v Rossii v 2004 i 2008 gg. (po dannym obsledovanii predpriiatii obrabatyvaiuschei promyshlennosti. Ekonomicheskii zhurnal VShE [Economic Journal of the HSE]. No.2, pp.202226

Yakovlev, Andrei and Demidova, Olga (2011). Access of firms to public procurement in Russia in the 2000s: before and after radical reform of regulation. International Journal of Economic Policy in Emerging Economies, Vol. 5, No. 2.

Yakovlev, A.; Demidova, O.; Balaeva. O. (2012) Prichiny snizheniia tsen na torgakh $i$ problemy ispolneniia goskontraktov., Moscow: Higher School of Economics, p.7

Yeltsin, Boris (2000). Prezidentskii Marafon. Moscow: AST Publishing.

Zaitseva, Tatiana (ed.) (2003) Reforma gosudarstvennoi sluzhby Rossii: istoriia popytok reformirovaniia s 1992 po 2000 god. Mosow: Ves Mir.

Zhulin A.; Ivanova O. (2008) "Monitoring vnedreniia administrativnykh reglamentov." Problems of State and Municipal Government No.2

Zotova Z.M., Salikov M.S. (1998) “Federativnoe ustroistvo Rossii: dve pozitsii.” Polis. No. 3 pp. $204-210$ 


\section{Articles in the media and non-refereed journals}

Alekseeva, Lyudmila. (2009) Press-conference: "Prizrak kommunizma protiv istoricheskoi khroniki” [online] (URL: http://www.newsland.ru/news/detail/id/413625/) (accessed February 12, 2012).

Bagrov, Andrei (1998). "Hudshee iz vozmozhnogo." Kommersant No.109 (1512).

Barakhova, Alla and Kudrina Olga (2006, June 6). Vitse-spikery vmesto denezhnykh meshkov. Kommersant, No.102 (3433).

Bekker, Alexander (2003). 'Piat' urovnei Shokhina. V RSPP pridumali reform pravitel'stva." Vedomosti. No.55 (April 1).

Bulavinov, Il'ia. (2003, November 10). “Koloda Rossiiskoi Federatsii.” KommersantVlast No. 44(547).

Busygina, Irina. (1997). “The President's representatives: problems of establishing and developing an institution.” Russian Politics and Law. Vol. 35(1).

Butrin, Dmitrii. “Vladimir Putin raspredeliaet odeiala.” Kommersant, №25 (3842), 15.02.2008.

"Effektivnyi menedzher v belom" (May 24, 2010) Novaya Gazeta, No.54

Fillipov, Petr and Boiko, Tatiana (2010). Administrativnaia reforma. Interviu s M.E.

Dmitrievym.(Online)., [URL: http://www.ru-90.ru/node/58] (Accessed June 29, 2013)

Freeland, Chrystina, Thornhill, John and Gowers, Andrew (1996, November 1). "Moscow's group of seven." Financial Times.

Frumkin, Konstantin (2013) “Sverkhministry.” Kompaniia. No.7(240). 
Ivanter, Alexander et al. (August 29, 2011) "Ne khvataet klassa”. Expert, No.34(767).

Kovalev, Georgii (2006, June 8). “Sovet Federatsii ne poddaetsia reformirovaniiu (The Federation Council does not succumb to reforms)". Politcom.ru. Available online at: http://www.politcom.ru/2868.html (accessed September 14, 2011).

"Korruptsia na goszakaze" (March 12, 2013). Nezavisimaia Gazeta. [Online]. Available at: http://www.ng.ru/editorial/2013-03-12/2_red.html (Accessed: August 15, 2013).

Kuznetsov, Yuri (2004). "Nekommercheskoe gosudarstvo" Otechestvennye Zapiski. No. $2(17)$.

“Medvedev: vorovstvo pri goszakupkakh prevyshaet trillion rublei." (October 29, 2010) Vedomosti. [Online]. http://www.vedomosti.ru/politics/news/1135201/medvedev vorovstvo pri go szakupkah_dostigaet_bolee_1 (Accessed: August 15, 2013).

Mezhevich, Nikolai M. (2005) “Osnovnye napravleniia regionalnoi politiki Rossiiskoi Federatsii." $S P b$. on-line [URL: http://dvo.sut.ru/libr/history/i299mez1/index.htm]

Migdisova S. et all (1995) “Lebed', Yavlinskii I Chernomyrdin - osnovnye pretendenty na post prezidenta Rossii.” FOM-Info, 48. [URL: http://bd.fom.ru/report/map/finfo/finfo1995/of1995_48/of19954803] (accessed Dec. 26, 2011).

“Ob”em goszakupok v 2010 godu ocenivaetsia v 15\% rossiiskogo VVP” (2009, November 20) Vedomosti [Online]. Available at: 
http://www.vedomosti.ru/finance/news/2009/11/20/889349 (Accessed: 26 August 2013).

Orlov, Dmitrii (2009). "Narushiteli Konvencii: Ob obschestvennom dogovore podlinnom I mnimom.” Nezavisimaya Gazeta. March 27. No.61

Ostrovsky, Arkady. (2004, November 13.). "Father to the Oligarchs - Anatoly Chubais is rich by Russian standards, but not as rich as the billionaires created by his privatisation reforms. The lurch into capitalism won him enemies but will history forgive him?" Financial Times.

Pavlikova, Olga. (2008). “Bol'she chlenov - men'she partii.” Gazeta No. October 31 Pavlovskiy, Gleb. (2009). “Upravliaemaia” democrtatiia, ili prosto - opytnaia?” Russkii Zhurnal, July 1; (On-line). [URL: http://www.russ.ru/Mirovayapovestka/Upravlyaemaya-demokratiya-ili-prosto-opytnaya]. Accessed on May $15,2011$.

Petrova, Anna et all. (1999). Vladimir Putin v otsenkah rossiian. FOM-Info, 34. [URL: http://bd.fom.ru/report/map/finfo/finfo1999/546 11191/of19993402] (accessed Dec. 27, 2011)

Putin, Vladimir. “Rossiia na rubezhe tysiacheletii,” Nezavisimaya gazeta, № 245 (2061), December 30, 1999.

Romancheva, I. (2006) “Gryzlov: «Reforma provalilas!»” Vzgliad, November 14. (Online) [URL http://www.vz.ru/politics/2006/11/14/57107.html] (accessed: June 10, 2013)

Rybin, Aleksandr (2009, June 26) “Konstitutsionnoe sootvetstvie." Rossiiskaia gazeta No.4940 (116). 
Sagdiev, Rinat (2010). "Krupnym planom: Ministerskoe hoziaistvo." Vedomosti. No.17 (2535), February 2.

Sagdiev, Rinat (2012). “Ministerskoe hoziaistvo - 2.” Vedomosti. No.244 (3258), December 24.

"Samoi korrumpirovannoi sferoi v armii stalo raspredelenie gosoboronzakaza" (July 11, 2013). RosBusinessConsulting. [Online]. Available at: http://www.rbcdaily.ru/society/562949987828212 (Accessed: August 15, 2013).

Sapozhkov, Oleg; Netreba, Petr (2009). "'Rosagrolizing' proveriaiut na rastochitelnost'". Kommersant. No.217 (4272), November, 20.

Smith. Mark (2006). "Sovereign Democracy: the Ideology of Yedinaya Rossiya." Conflict Studies Research Centre. 6(37)

“Stepashin predlagaet otlozhit' v storonu 94-i FZ i oprobovat' federalnuiu kontraktnuiu sistemu" Interfax. . [Online]. Available at: http://www.interfax.ru/realty/realtyinf.asp?id=187301\&sec=1461 (Accessed: August 15, 2013).

"Stepashin: zakon o goszakupkakh - samyi korruptsiogennyi" (July 15, 2008) Gazeta.ru. [Online]. Available at: http://www.gazeta.ru/news/business/2008/07/15/n_1243468.shtml (Accessed: August 15, 2013).

"Strategiia-2020: Novaia model rosta - novaia sotsialnaia politika." (Online). [URL: http://2020strategy.ru/data/2012/03/14/1214585998/1itog.pdf] (Accessed: October 22, 2013). 
Surkov, Vladislav (2003). Natsionalizatsia budushchego: paragrafy pro suverennuiu demokratiiu. Expert, 43(537).

Treisman, Daniel (2002). “Russia renewed?” Foreign affairs, Vol. 81, No.6

Vasileva, Yuliya. (2008) Reforme dobavili srok. Rossijskaya Biznes-gazeta No.642 of February 26.

Zubchenko, Evgeniia (2010) “Sem’ raz skhodi.” Novye Izvestiia, December 6. (Online. URL: http://www.newizv.ru/economics/2010-12-06/137497-sem-razshodi.html) 


\section{List of Appendixes}

\section{Appendix I. The Media Context of the Reform of Public Administration.}

Yearly quantity of publications on the topic of public administration reform in the Russian most influential newspapers and magazines.

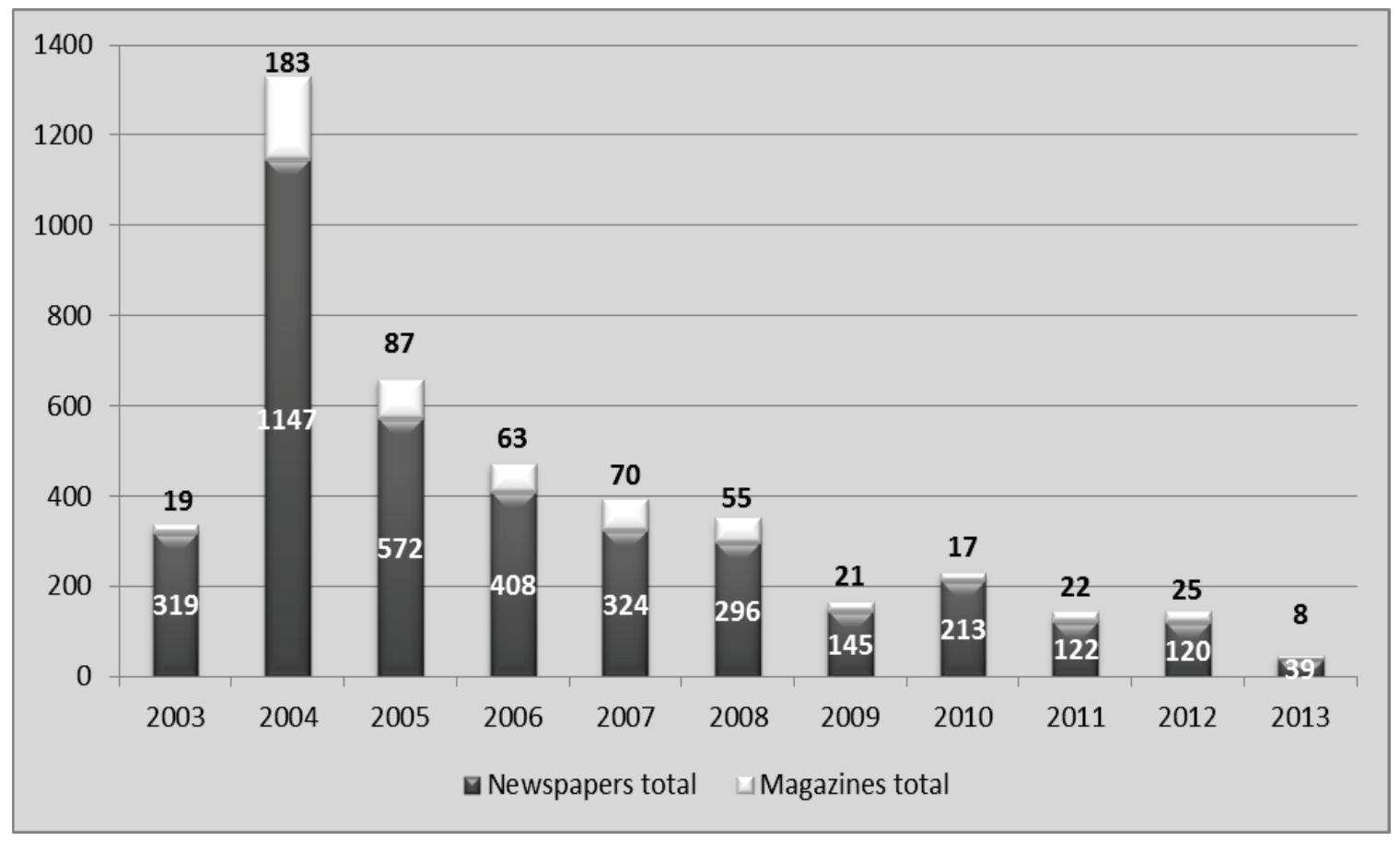

The sample included articles published between July 23, 2003 (official start of the reform) and July 23, 2013 in five major Russian newspapers: Rossiiskaia Gazeta, Kommersant-Daily, Izvestia, Vedomosti, Komsomolskaia Pravda; and three major magazines: Kommersant-Vlast, Itogi, Expert. The media sources were chosen on the basis of the current (2013) citation index, prepared by the Medialogia Research Group. The sample of total 4275 articles was prepared using the Factiva search engine. Only articles, that contained the exact phrase 'Administrativnaia reforma' were selected to the sample.

\section{Refer to Introduction, p. 6.}




\section{Appendix II. Structure of the Government of Russian Federation ${ }^{1}$}

\section{Government of Russian Federation \\ II. Federal ministries Military \& Security Block}

- Ministry for Emergency Situations

- Ministry of Internal Affairs

- Ministry of Defense

Economic Block

- Ministry of Finance

- Ministry of Economic Development and Trade

- Ministry for Antimonopoly Policy and Business Support

- Ministry for Taxes and Borrowings

- Ministry of Agriculture

Political Block

- Ministry of Foreign Affairs

- Ministry of Justice

Social Block

- Ministry of Public Health

- Ministry of Education

- Ministry of Culture

- Ministry of Labor Affairs and Social Development

Industry and Technology Block

- Ministry of Energetic

- Ministry for Press, Tele- and Radio Broadcasting and Mass-Media

- Ministry of the Nuclear Energy

- Ministry of Natural Resources

- Ministry of Industry, Science and Technology

- Ministry of Railways

- Ministry of Communication and Informatization

- Ministry of Transport

- Ministry of Federal Property

\section{State Committees}

- State Committee of Sport and Tourism

- State Committee for Fishery

- State Committee for Metrology and Standardization

${ }^{1}$ Structure of the government is presented as of June, 2013. The scheme reflects a threelayer system of government, introduced by the presidential decree No. 314 from March 9, 2004 "On the system and structure of the federal organs of executive power". Although ministries, services and agencies have undergone through a series of merges, rearrangements and liquidations, the general principles of organization of public administration on the federal level remained intact. As it was stated in the decree public institutions are grouped according their functional capacity and administrative subordination. 
- State Committee for Statistics

- State Committee for Housing and Communal Services

- State Committee for Customs

- State Committee for Control Over the Circulation of Narcotic Drugs

IV. Federal Commissions

- Federal Commission for Control Over the Stock Market

- Federal Commission for Energetic

V. Federal Services

- State Courier Service

- Foreign Intelligence Service

- Federal Archive Service

- Federal Service for Geodesy And Cartography

- Federal Service for Railroad Military Forces

- Federal Service for the Land Cadastre

- Federal Service for the Environmental Monitoring

- Federal Security Service (FSB)

- Federal Service for Bankruptcy Affairs

- Federal Service of Tax Police (abolished)

- Federal Border Guard

- Federal Service for Especial Construction

\section{Federal Agencies}

- Russian Aeronautic and Aerospace Agency

- Russian Agency for Ammunition \& Military Supplies

- Russian Agency for Ordinary Weapons

- Russian Agency for Control Systems

- Russian Agency for Shipbuilding

- Russian Agency for Trademarks and Patents

- Russian Agency for State Reserves and Supplies

- Russian Agency for State Telecommunications

\section{Federal Inspectorates}

- Federal Inspectorate for Nuclear and Radiation Security

- Federal Inspectorate in the Sphere of the Nature Management

VIII. Other Departments and Agencies

- Federal Service for Special Presidential Programs

- State's Technical Inspectorate

- President's Administrative Department

- Committee for Foreign Cooperation in the Military and Defense Spheres

- State Committee for Financial Monitoring

- State Committee for Military and Defense Contractual Work 